\title{
Standing Committee
}

for Economic and Commercial Cooperation

of the Organization of Islamic Cooperation (COMCEC)

on for De

COMCEC

Risk and Crisis Management in Tourism Sector: Recovery From Crisis in the OIC Member Countries

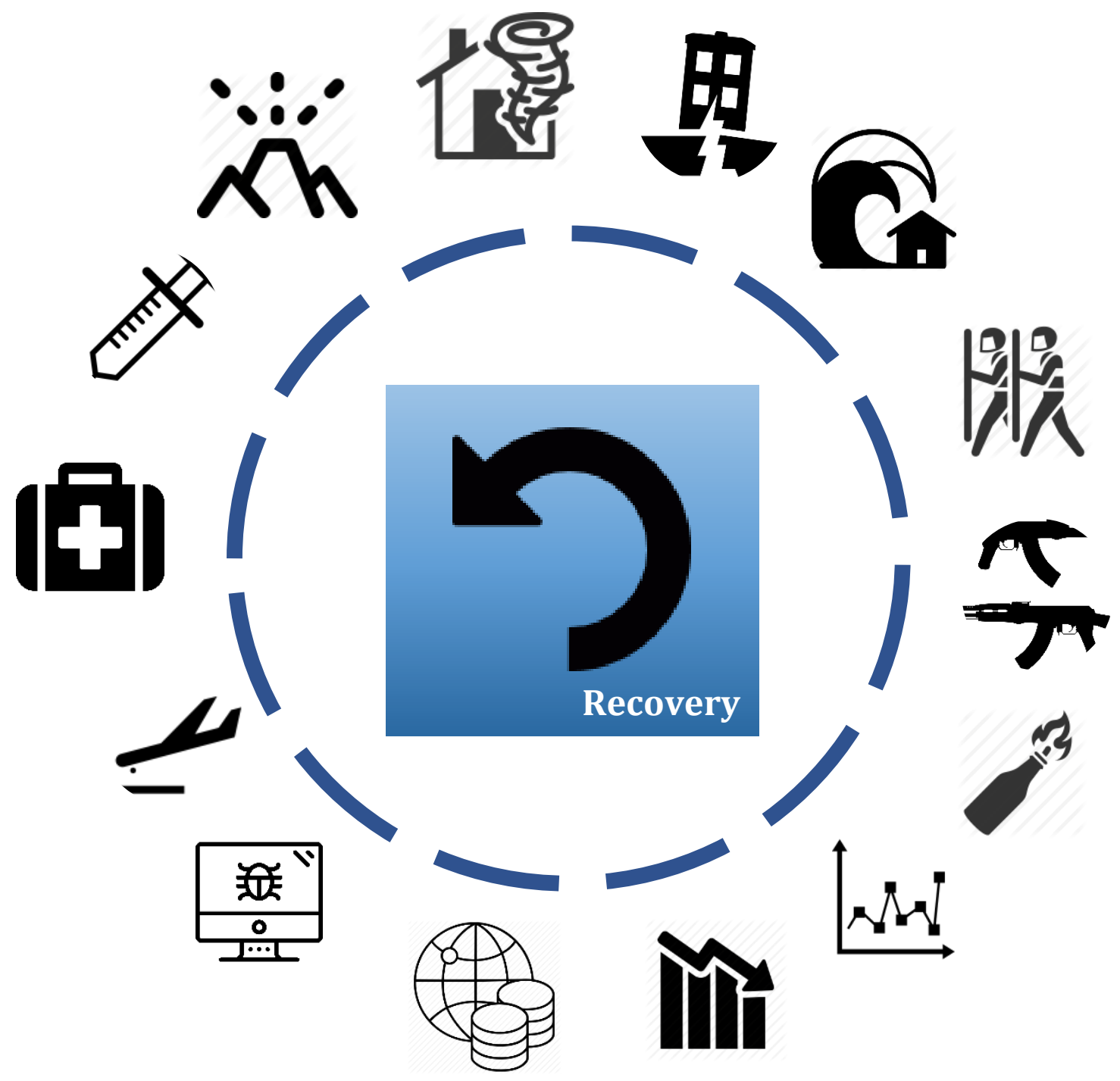

COMCEC COORDINATION OFFICE

August 2017 



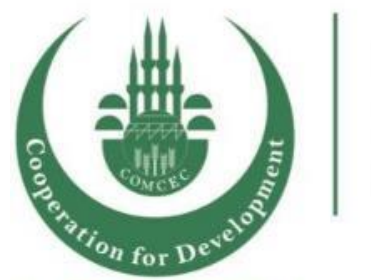

Standing Committee for Economic and Commercial Cooperation of the Organization of Islamic Cooperation (COMCEC)

COMCEC

Risk \& Crisis Management in Tourism Sector:

Recovery From Crisis in the OIC Member Countries

COMCEC COORDINATION OFFICE

August 2017 
This report has been commissioned by the COMCEC Coordination Office to Tourism Development International. Views and opinions expressed in the report are solely those of the author(s) and do not represent the official views of the COMCEC Coordination Office or the Member States of the Organization of Islamic Cooperation. Excerpts from the report can be made as long as references are provided. All intellectual and industrial property rights for the report belong to the COMCEC Coordination Office. This report is for individual use and it shall not be used for commercial purposes. Except for purposes of individual use, this report shall not be reproduced in any form or by any means, electronic or mechanical, including printing, photocopying, CD recording, or by any physical or electronic reproduction system, or translated and provided to the access of any subscriber through electronic means for commercial purposes without the permission of the COMCEC Coordination Office.

For further information, please contact:

COMCEC Coordination Office

Necatibey Caddesi No: 110/A

06100 Yücetepe

Ankara/TURKEY

Phone: 903122945710

Fax: 903122945777

Web: www.comcec.org 


\section{Table of Contents}

Page No

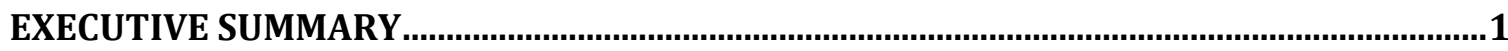

1. Tourism Risk and Crisis Management Frameworks ..................................................... 1

2. Types and impacts of Crises in Tourism........................................................................... 2

3. Mitigation and Response Strategies and Actions............................................................. 5

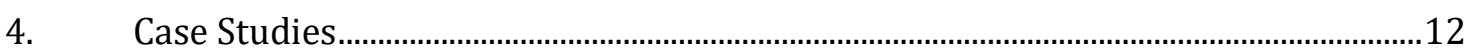

INTRODUCTION

1. CONCEPTUAL FRAMEWORK: Risk and Crisis Management .................................17

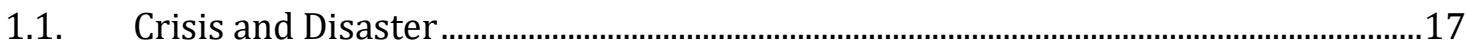

1.2. Risk Management..................................................................................................18

1.3. Tourism Crisis Management Frameworks ..................................................................19

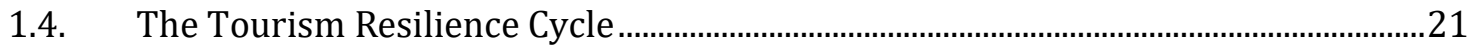

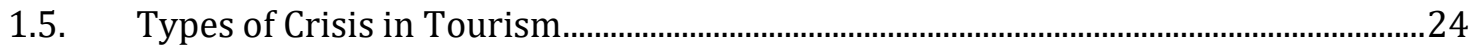

1.6. Impacts of Crises and Recovery in the Tourism Sector..................................................29

1.7. The Role of Media and Travel Advisories ..........................................................................

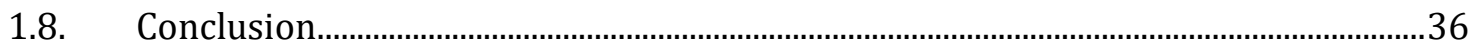

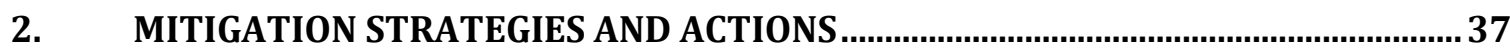

2.1. Tourism Crisis Management and Disaster Risk Reduction Strategies ........................37

2.2. Key Organisations and Roles in Tourism Crisis Management......................................38

2.3. Tourism Crisis Responses: Strategies and Actions .......................................................40

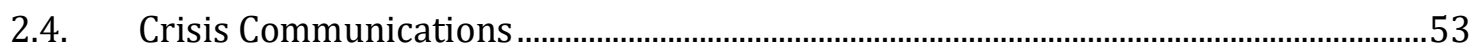

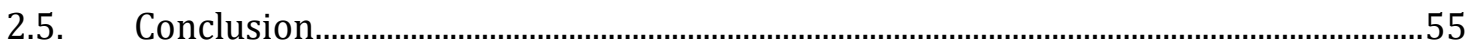

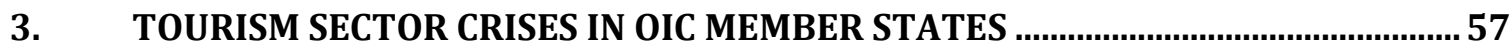

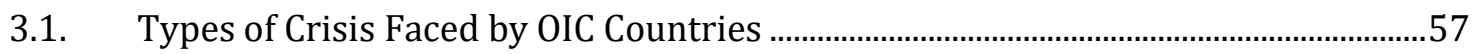

3.2. Impact of Crises on OIC Member States' Tourism Sectors...........................................60

3.3. Response Strategies and Actions: During and Post Crises...........................................61

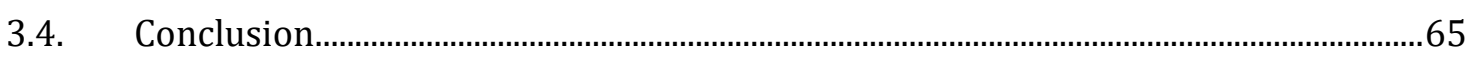




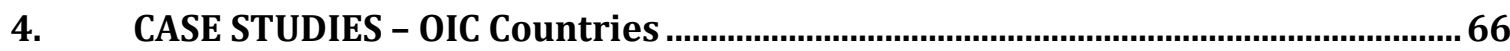

4.1. Case Study 1 - Indonesia (Field study) ..........................................................................66

4.2. Case Study 2 - Turkey (Field study) ................................................................................78

4.3. Case Study 3 - Tunisia (Field study) ………………....................................................86

4.4. Case Study 4 - The Gambia (Desk study) ............................................................................

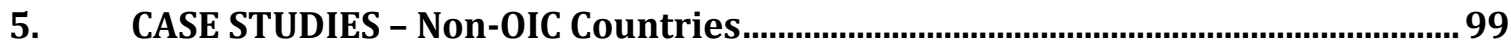

5.1. Case Study 1 - South Africa (Field study) ……...................................................................99

5.2. $\quad$ Case Study 2 - United Kingdom (Desk study)................................................................ 108

5.3. Case Study 3 - Thailand (Desk Study) ……...........................................................................116

5.4. Case Study 4 - Sri Lanka (Desk study) ………................................................................. 125

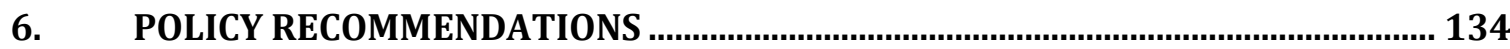

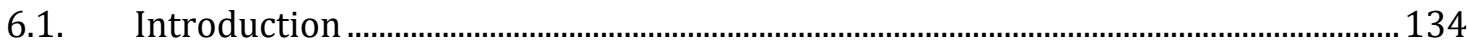

6.2. Conclusions from the Case Studies …….........................................................................134

6.3. Public and Third Sector Responses and Resilience ...................................................... 136

6.4. Private Sector Responses and Resilience.......................................................................... 143

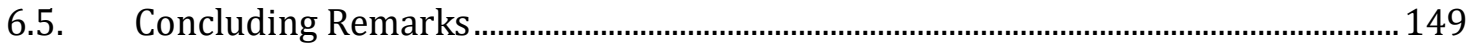

\section{REFERENCES}




\section{List of Tables}

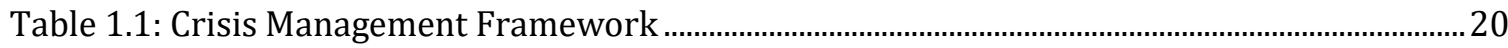

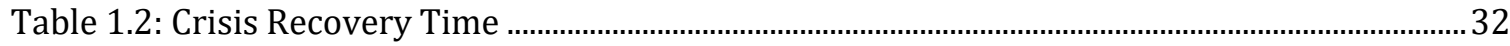

Table 2.1: Reasons for effectiveness of measures taken by own Organization..................................45

Table 2.2: Test messages aimed at revitalising tourism to bushfire affected area of Australia .....50

Table 2.3: Principles of Crisis Communications...................................................................................54

Table 2.4: Before Crisis: preparing for the worst................................................................................55

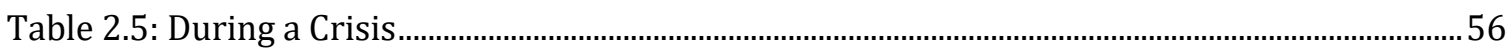

Table 2.6: Following a Crisis: rebuilding tourist confidence.................................................................56

Table 3.1: Environmental Crises affecting Tourism in OIC Countries...................................................58

Table 3.2: Societal/Political Crises affecting Tourism in OIC Countries ...............................................58

Table 3.3: Health-Related Crises affecting Tourism in OIC Countries....................................................59

Table 3.4: Technological Crises affecting Tourism in OIC Countries....................................................59

Table 3.5: Economic Crises affecting Tourism in OIC Countries.............................................................60

Table 4.1: International Visitor Arrivals and Foreign Exchange Earnings - Indonesia......................68

Table 4.2: International Visitor Arrivals and Foreign Exchange Earnings - Turkey ………………....80

Table 4.3: International Visitor Arrivals and Foreign Exchange Earnings - Tunisia............................87

Table 4.4: International Visitor Arrivals and Foreign Exchange Earnings - The Gambia ...............95

Table 5.1: International Visitor Arrivals and Foreign Exchange Earnings - South Africa............. 100

Table 5.2: International Visitor Arrivals and Foreign Exchange Earnings - UK............................... 109

Table 5.3: International Visitor Arrivals and Foreign Exchange Earnings - Thailand..................... 117

Table 5.4: International Visitor Arrivals and Foreign Exchange Earnings - Sri Lanka................... 127 


\section{List of Figures}

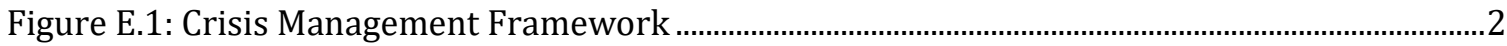

Figure E.2: Key Actions in the Six Phases of Crisis Management ……...............................................10

Figure 1.1: Disaster Risk Management Strategy ……..........................................................................18

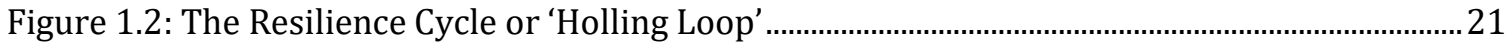

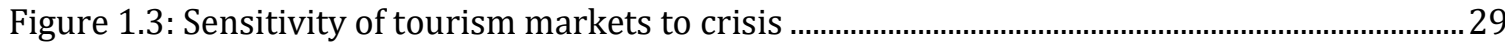

Figure 1.4: Length of time taken for own organisation to recover from crisis....................................33

Figure 4.1: Growth (decline) in International \& Domestic Tourism to Indonesia 2000-10 ............71

Figure 4.2: Crisis Management after 2002 Bombings in Bali................................................................. 72

Figure 4.3: Indonesia's 'Nine Steps to Tourism Crisis Recovery' ...........................................................73

Figure 4.4: Crisis Management Scheme for Tourism............................................................................74

Figure 5.1: Arrivals to South Africa from Outside Africa, 2005-15 …................................................ 101

Figure 5.2: International Tourism Arrivals to Sri Lanka, 1995-2016 ................................................. 128 


\section{List of Abbreviations}

\begin{tabular}{|c|c|}
\hline ASATA & Association of South African Travel Agents \\
\hline ASEAN & Association of Southeast Asian Nations \\
\hline ASSET & Association of Small Scale Enterprises in Tourism \\
\hline BSA & Brand South Africa \\
\hline CAST & Caribbean Alliance for Sustainable Tourism \\
\hline CDEM & Civil Defence and Emergency Management \\
\hline CDERA & Caribbean Disaster Emergency Response Agency \\
\hline CMSC & Culture, Media and Sport Committee \\
\hline COMCEC & $\begin{array}{l}\text { Standing Committee for Economic and Commercial Cooperation of the Organization } \\
\text { of Islamic Cooperation }\end{array}$ \\
\hline CRSTDP & Caribbean Regional Sustainable Tourism Development Programme \\
\hline СТВ & Ceylon Tourist Board \\
\hline DMO & Destination Management Organisation \\
\hline DRR & Disaster risk reduction \\
\hline ECOWAS & Economic Community of West African States \\
\hline FMD & Foot and Mouth Disease \\
\hline GDP & Gross Domestic Product \\
\hline GFC & Global Financial Crisis \\
\hline GMS & Greater Mekong Sub-Region \\
\hline GRDP & Gross Regional Domestic Product \\
\hline GTA & Gambia Tourism Authority \\
\hline GTB & Gambia Tourist Board \\
\hline IATA & International Air Transport Association \\
\hline JICA & Japan International Cooperation Agency \\
\hline LEP & Local Enterprise Partnership \\
\hline MENA & Middle East and North Africa \\
\hline MICE & Meetings, Incentives, Conferences and Events \\
\hline МТРВ & Maldives Tourism Promotion Board \\
\hline NCA & National Constituant Assembly \\
\hline NGO & Non-governmental organization \\
\hline NTA & National Tourism Administration \\
\hline NTB & Nepal Tourism Board \\
\hline NTO & National Tourism Organisation \\
\hline OSU & One Stop Unit \\
\hline PATA & Pacific Asia Travel Association \\
\hline RDAs & Regional Development Agencies \\
\hline SADC & Southern African Development Community \\
\hline SANCB & South African National Convention Bureau \\
\hline SARS & Severe Acute Respiratory Syndrome \\
\hline SAT & South African Tourism \\
\hline SATSA & Southern Africa Tourism Services Association \\
\hline
\end{tabular}




$\begin{array}{ll}\text { SLTB } & \text { Sri Lanka Tourist Board } \\ \text { SLTDA } & \text { Sri Lanka Tourism Development Authority } \\ \text { SLTPB } & \text { Sri Lanka Tourism Promotions Bureau } \\ \text { SMCs } & \text { South Mediterranean Countries } \\ \text { TAT } & \text { Tourism Authority of Thailand } \\ \text { TB } & \text { Tourist Board } \\ \text { TBCSA } & \text { Tourism Business Council of South Africa } \\ \text { TOMSA } & \text { Tourism Marketing South Africa } \\ \text { TURSAB } & \text { Association of Turkish Travel Agencies } \\ \text { UK } & \text { United Kingdom } \\ \text { UN } & \text { United Nations } \\ \text { UNEP } & \text { United Nations Environment Programme } \\ \text { UNWTO } & \text { World Tourism Organization } \\ \text { VAT } & \text { Value Added Tax } \\ \text { VFR } & \text { Visiting Friends or Relatives } \\ \text { WHO } & \text { World Health Organization } \\ \text { WTTC } & \text { World Travel \& Tourism Council }\end{array}$




\section{EXECUTIVE SUMMARY}

\section{Tourism Risk and Crisis Management Frameworks}

Crises are periods of intense uncertainty characterized by unpredictability and loss of control over key functions of systems (Moreira, 2007). Generally, a crisis affecting tourism manifests as an event or set of circumstances which compromise or damage the market potential and reputation of a tourism business or an entire region (PATA, 2011). Crisis management consists of the "strategies, processes and measures which are planned and put into force to prevent and cope with crisis" (UNWTO, 2011). Risk and crisis management is an integral component of overall tourism and hospitality management, practised at destination level by public sector agencies and communities, larger enterprises at destination level and by individual businesses.

Effective risk management can prevent an issue from becoming a crisis. Poor understanding and management of risks can lead to a crisis situation. Risk management involves assessing the probability of negative events that may lead to the tourism sector being unable to operate normally. Six functions of risk management are identified by PATA (2011):

1. Identify: Identify risks or hazards before they become realities.

2. Analyse: Evaluate the probabilities, time-frames and potential impacts of each risk and then classify and prioritise them.

3. Plan: Formulate contingency action plans for mitigating the potential impact of each risk.

4. Track: Monitor the likely effectiveness of these plans by reviewing evolving risks.

5. Control: Revise the plans according to data from the monitoring stage.

6. Communicate: Ensure stakeholder buy-in and support in monitoring changes in the risk environment.

Tourism managers and policy-makers need to understand the nature of crises and their likely development and possible magnitude. Faulkner (2001) proposed a six-phase framework for understanding the stages of a crisis and the responses necessary from stakeholders (Figure E.1). ${ }^{1}$

\footnotetext{
${ }^{1}$ This framework is often referred to as 'Faulkner's Tourism Disaster Management Framework', but in this report we use 'crisis' to cover both natural disasters and human-induced crises.
} 
Figure E.1: Crisis Management Framework

\begin{tabular}{|c|c|c|c|}
\hline No. & Phase & Principal strategies \& actions & Key stages \\
\hline 1 & Pre-event & Contingency planning & $\begin{array}{l}\text { Prevention, based on } \\
\text { known information }\end{array}$ \\
\hline 2 & $\begin{array}{l}\text { Prodromal (onset } \\
\text { of crisis situation) }\end{array}$ & Initiation of contingency plan & Response \\
\hline 3 & Emergency & Protective actions during crisis & Response \\
\hline 4 & Intermediate & $\begin{array}{l}\text { Short-term needs addressed, clear } \\
\text { communication strategy in place }\end{array}$ & Response \\
\hline 5 & Recovery & $\begin{array}{l}\text { Restoring infrastructure, facilities, and } \\
\text { tourist attractions, coordinated and } \\
\text { sustained marketing response }\end{array}$ & $\begin{array}{l}\text { Stimulation of recovery } \\
\text { in mid and long term }\end{array}$ \\
\hline 6 & Resolution & $\begin{array}{l}\text { Review of actions taken to feed into further } \\
\text { contingency plans }\end{array}$ & $\begin{array}{l}\text { Prevention, based on } \\
\text { new learning }\end{array}$ \\
\hline
\end{tabular}

Based on Faulkner (2001)

Crisis management planning entails developing policies and procedures according to these six phases; the principal actions are given in sub-section 3 below.

\section{Resilience in Tourism}

Resilience is the ability of a system to reduce the chances of a crisis occurring, mitigate the impacts of a crisis, and recover its essential structures and functions quickly. The speed of recovery from a crisis (or stress event) will depend on different forms of capital (social, political, economic) built up in the phases before the event. Understanding resilience concepts can help to identify the necessary interventions to enable a system to maintain its essential functions and allow faster and more successful regeneration. Cochrane (2010) developed the concept in the context of tourism as 'the sphere of tourism resilience', with the core features of a resilient system being:

- The ability to understand and harness market forces

- Collaboration between stakeholders to create strong networks

- Leadership, normally provided by the public sector

- Sufficient flexibility to adapt to change, including adaptive learning.

\section{Types and Impacts of Crises in Tourism}

In terms of predictability and avoidance, there are two broad categories of tourism-related crisis: those beyond the control of managers, politicians and policy-makers, such as natural disasters, disease epidemics, and sudden global economic events, and those resulting from a failure of management and government to deal with predictable risks. These include (within a business) poor management or leadership, financial fraud, loss of data, destruction of place of business due to fire or flood without adequate back-up or insurance cover; and (at the level of a region or country) acts of war or terrorism, political upheavals, crime waves, and anthropogenic climate change. 
The UNWTO (2011) places tourism crises into five categories:

1. Environmental, including geological and extreme weather events, and human-induced situations such as climate change and deforestation

2. Societal and political, including riots, crime waves, terrorist acts, human rights abuses, coups, violently contested elections

3. Health-related, such as disease epidemics affecting humans or animals

4. Technological, including transportation accidents and IT system failures

5. Economic, such as major currency fluctuations and financial crises

In addition, specific events may affect individual businesses, such as

6. Accidents affecting clients in the public realm, e.g. traffic accidents, mugging, drowning

7. Accidents or events within an individual enterprise, e.g. fires, injuries, food poisoning

The tourism and hospitality industries of OIC member countries are vulnerable to the same types of challenges as other countries. An analysis of crisis events in member states for this report indicated that the most significant category is 'societal and political'.

Any significant crisis in Categories 1-5 will affect the tourism sector's ability to operate normally, either because of damage to infrastructure and facilities, or because the destination will be perceived as unsafe. The principal consequence of crises is a rapid decline in overall tourist arrivals and occupancy levels for hotels, tour operators and airlines, due to:

- physical damage to tourism infrastructure (especially in the case of natural disasters)

- heightened perception of risk and erosion of consumer confidence (especially in the case of terrorist attacks)

- decisions by consumers to cancel or postpone theirtrips

- removal by tour operators of holidays in affected countries from their brochures and product listings

- decisions by airlines to reduce flights to affected destinations

These issues will result in a loss of jobs and a fall in the economic benefits of tourism, including reduced incomes for businesses and individuals along the supply chain and loss of tax revenues for governments, and (in the case of a crisis of longer duration) reduced investment in facilities.

Many disruptive events are limited to a relatively small geographic area within a country but market concern about the safety of travel and negative image may apply to the whole country rather than be limited to the specific area affected. 
The effect of events may be of relatively short duration given appropriate remedial actions, including infrastructure repair, security improvements and reassuring communications. These can bring the sector back to normal operations within the short- to-mid-term although, where the context of the country is still seen as dangerous, recovery is likely to take longer. The survey of tourism businesses carried out for this study indicates that individual businesses can take several years to recover from crises.

Sensitivity to destination disruption differs between markets and segments, depending on age, background, cultural outlook and experience of travel. The survey of tourism businesses for this report indicated that West European markets are the most sensitive to crises, followed by North America. In addition, there is evidence that terrorist attacks (or even the threat of attacks) form the most common cause of trip cancellations (Misrahi, 2016). This was confirmed by our study, where terrorism was cited as the most significant event to impact on tourism in respondents' countries.

During the global financial crisis of 2008/9, the tourism industry experienced significant decline and changes in travel habits, including a decrease in long-haul travel in favour of intraregional and domestic trips (UNWTO \& ILO, 2013). Destinations with strong links to European and North American markets were the worst affected, while countries with more diversified source markets were comparatively less affected. In terms of tourism segments, business travel suffered more than leisure travel because of the global slowdown in business activity.

\section{The Role of the Media}

The press and other forms of media have significant influence on travellers' decision-making. Graphic images of disasters may be accompanied by accounts of human suffering and damage to infrastructure and facilities. The 'ASEAN Tourism Crisis Communications Manual' (2015) notes that a relatively minor incident can be escalated into a crisis by prominent media report. Meanwhile, reporting of recovery is often less extensive because it is considered less newsworthy.

The expansion of user-generated content on social media has democratised the propagation of messages and images. This represents both a threat and an opportunity for destinations, particularly during and following a crisis. The threat is the risk of sensationalist reporting that exaggerates the scale of the problem; while the opportunity is to respond rapidly with positive material on the actual situation and the actions taken to return to normal. Government and private sector organisations are increasingly adept at using all channels to promote positive messages during the recovery period. 


\section{Mitigation and Response Strategies and Actions}

Due to the frequency of crises and consequent institutional learning through efforts to deal with them, crisis management techniques are now well understood and offer sophisticated ways of avoiding their occurrence and mitigating their negative consequences through swift and effective actions.

Many countries have a national system for disaster or crisis risk reduction and management, normally a group or committee headed by a nominated government department. It is not possible to be prescriptive about the members of the national body since each country is different, but the committee is likely to be hosted by a top government department such as the Ministry for Home Affairs / Department for Homeland Security at national level, or by a regional government body. In most cases, representatives of key agencies such as police, health, transportation, public works and city administration are involved.

Where crises affect (or are likely to affect) tourism, governments and industry bodies must ensure that tourism stakeholders are included in crisis management planning alongside civil defence and community response groups. However in some cases the priorities of public sector management units do not align with tourism interests, as governments may focus on the magnitude of the emergency in order to maximise international support, while the tourism sector will aim to maintain business continuity by ensuring normal operations in unaffected areas as well as restoring services in the affected area.

In any tourism system, it is only the public sector which has the necessary resources, long-term view and balanced approach towards all stakeholders to provide the strong leadership essential for the success of the tourism industry, including creating benefits for as many stakeholders as possible. In recognition of this, the UNWTO (2017a) recommends that the national tourism authority for each country forms an executive committee or task force responsible for risk management in key areas. This can be hosted by the government ministry or other department responsible for tourism or by a public-private sector partnership responsible for national-level destination management and promotion such as a Tourism Board. In either case, there should be strong representation by private sector associations, major companies and regional Destination Management Organisations (DMOs), as well as the resident population of places directly or indirectly affected by tourism through their jobs and livelihoods.

While governments need to provide the overall framework and leadership, individual tourism, hospitality and leisure enterprises are the primary interface with the customer and must have contingency plans in place for dealing with emergencies. Individual enterprises must also plan for site-specific risks such as a fire on the premises or accidents affecting individual tourists.

Destinations hit by crisis events should address recovery in line with the six phases of the Crisis Management Framework shown in Figure E.1. Initial leadership must come from the national (or regional) disaster or crisis management unit, with follow-up led by the tourism authority's task force in close collaboration with local tourism operators. 


\section{Phase 1: Pre-crisis Stage}

Before any crisis event occurs, the government-led task force should work with businesses and trade associations to prepare sector-specific plans. The more detailed the pre-event planning, the more likely it is that the outcome will be effective. The planning process should be informed by understanding of market responses to different types of crisis. Scenario planning is a useful approach, based on examining how elements of the tourism system interact with the wider societal and economic context. Understanding these relationships is a precursor to creating more resilient tourism systems. Once the risks and possible crises are identified, plans should be established for each possible event, including specific communications plans: Walters et al (2016) report on the reputational damage which can be caused by sensationalist reporting, and a clear crisis communications plan can minimise this threat.

The principal pre-crisis management steps for the tourism sector are therefore to:

1. Set up a tourism crisis recovery task force or executive committee, linked to the national disaster and risk management body, with representatives from public and private sector.

2. Nominate a location as a crisis headquarters in the event of a crisis.

3. Designate a spokesperson, who will work closely in the event of a crisis with the national body to ensure consistency of message.

4. Private companies should designate a senior staff member as lead, in addition to allocating specific roles and responsibilities in responding to a crisis.

5. Establish the principles of a crisis communications plan, in particular the human, financial and technical resources required.

6. Prepare draft messages to issue in the event of crises, if necessary using the templates provided by the UNWTO's 'Toolbox for Crisis Communications in Tourism' (2011).

7. Plan procedures and policies to implement if a crisis occurs.

8. Maintain up-to-date intelligence on the distribution of tourists in-country and key contacts with consular officials and trade associations.

9. Maintain knowledge of market trends and possible reactions to different types of crisis.

10. Cultivate good relations with the media, so that in the event of a crisis positive messages are more likely.

11. Create warm relations with tour operators personnel and past and potential visitors. This will generate emotional and social capital and help create a supportive reaction to a crisis.

12. Train personnel in safety and security issues to enhance awareness amongst employees, and to minimise risks to tourists and employees, as well as property damage. 


\section{Phase 2: Prodromal Stage}

Once an emergency situation has begun to develop, a competent and speedy response may prevent it spiralling into a full crisis. Not all businesses or even government departments will necessarily be immediately aware of the situation, so they will need to be warned. The principal actions in this phase are:

1. Increase frequency of communications between members of the tourism sector task force, with instructions to member bodies to stand by for action.

2. Businesses should move their crisis management plan into the operational phase.

3. Finalise pre-prepared messages to issue to media and the public.

4. Activate a communications centre to handle enquiries from relatives of people affected by the incident and mitigate damage to the destination's image.

\section{Phase 3: Emergency Stages (immediate crisis response)}

Key actions at this stage are to:

1. Ensure safety and welfare of customers by covering their basic needs, followed by evacuation to home country or another area if necessary.

2. Ensure safety and welfare of staff by transferring non-essential members outside the affected area.

3. Carry out emergency infrastructural repairs.

4. Issue regular updates on the situation via the crisis communications centre, with transparent and accurate messages. Openness to enquiries is vital to restrict sensationalist and inaccurate reporting.

5. Rapid and honest communication by businesses with booked customers to advise on the situation, either encouraging them to continue with their visit to an unaffected part of the country, or offering a refund or alternative holiday at a later date.

\section{Phase 4: Post-crisis (intermediate, mid-term)}

Efforts to ensure recovery should accelerate as soon as the emergency phase is over. Government commitment to the tourism sector and leadership is essential. Until repairs are made to the key infrastructure and facilities used by tourists in the affected area, efforts to promote the recovery of the destination should be limited to unaffected areas. Whatever the crisis, the optimal response is to provide timely information that is accurate, credible and transparent, enabling stakeholders to act on it and prospective visitors to make informed decisions and modify their travel arrangements to ensure their safety. Communications should be directed at the trade (tour operators, travel agents, conference organisers) and individual tourists. Business owners and managers can focus on limiting the physical and reputational damage to their business. 
Responses to crisis should include:

1. A coordinated response between public and private sector bodies, following the preprepared plan of the local or national crisis management task force.

2. Repairs to infrastructural damage to ensure normal functioning of tourism as quickly as possible.

3. Increased marketing, including familiarisation trips and other promotional efforts, using optimistic messages which focus on positive aspects of the destination. If necessary, engage a specialist PR firm.

4. Circulation of businesses' own information on the crisis and recovery to complement information being disseminated by the lead government agency and tourism task-force, and to counter the spread of "fake news" on social media.

5. Targeting of less crisis-sensitive markets and segments (e.g. domestic and diaspora) in order to ensure business viability.

6. Improvements to security (especially in the case of political upheaval or terrorist attacks).

7. Strengthened public/private partnerships and cooperation.

8. Fiscal and monetary measures by government such as subsidies or tax holidays to reduce business costs and help avoid redundancies.

\section{Phase 5: Post-crisis Recovery (long term)}

The intermediate stages of crisis management will evolve into longer term measures in six key areas:

1. Plan for infrastructural improvements.

2. Adjust investment conditions through fiscal and other incentives to influence the scale and timing of future investments

3. Increase professionalism in tourism and hospitality, particularly to ensure that local people have the skills to access jobs at all levels of the industry, as well as training frontline personnel in safety and security procedures

4. Address market perceptions to rebuild destination image through regular updates on websites and Facebook pages about recovery, news of activities or festivals, familiarisation trips for journalists and bloggers, or webcams in key locations showing that the area is safe. Comments should be accurate and positive and focus not just on individual businesses but also other local businesses to show an active, cohesive and attractive destination worth visiting. Islamic countries may wish to highlight traditions of welcome and hospitality and other aspects of cultural and natural heritage.

5. The crisis may break the established mould of tourism, creating opportunities to develop in new directions. Emerging trends, markets and new trade links should be reviewed and can be more readily exploited at this stage. Targeting prior visitors, neighbouring country tourists and segments that are less susceptible to political unrest or disease outbreaks can be effective. Individual businesses should work closely with the local DMO to ensure consistency of message. 
6. Destinations can develop new products according to the available resources and in line with market trends.

\section{Phase 6: Resolution}

Both public and private sector bodies should review the actions taken in the previous phases for effectiveness and make adjustments, consistent with the resources available to them. This will build resilience into individual organisations and the wider tourism system through increased awareness of how to respond to crises and changing market trends, and ensure that future planning takes account of past successful (and less successful) strategies.

The key policies at this stage are to:

1. Monitor the success of measures short and medium-term measures (e.g. by research into visitor profiles and satisfaction).

2. Evaluate longer-term measures necessary to rebuild the industry.

3. Modify future contingency plans based on lessons learned from the crisis (in other words creating a feedback loop).

The recommendations for crisis management planning and action are summed up in Figure E.2. 
Figure E.2: Key Actions in the Six Phases of Crisis Management
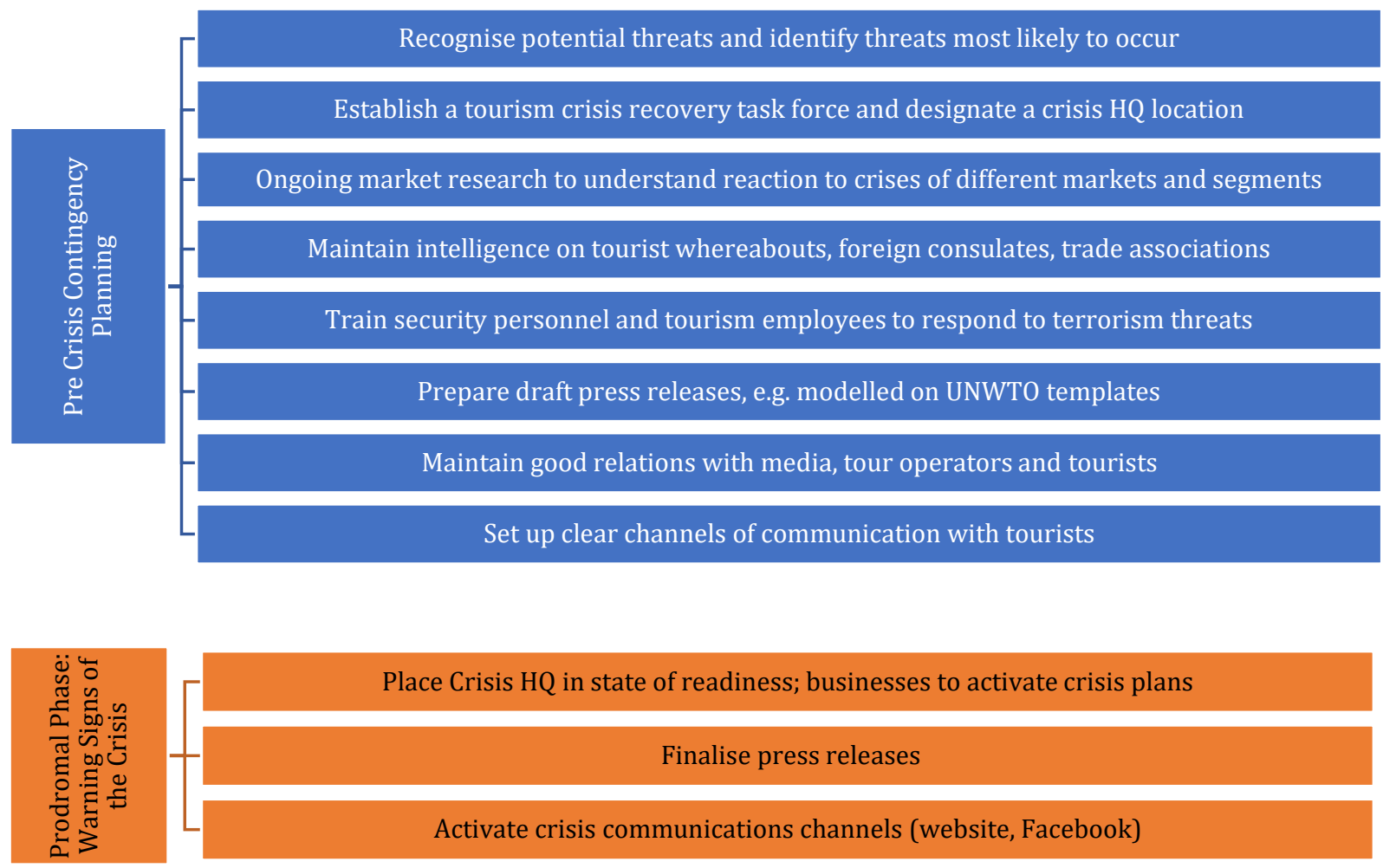

Place Crisis HQ in state of readiness; businesses to activate crisis plans

Finalise press releases

Activate crisis communications channels (website, Facebook)

Activate Crisis HQ
Provide medical, food and other assistance to ensure safety and welfare of tourists, employees and
residents



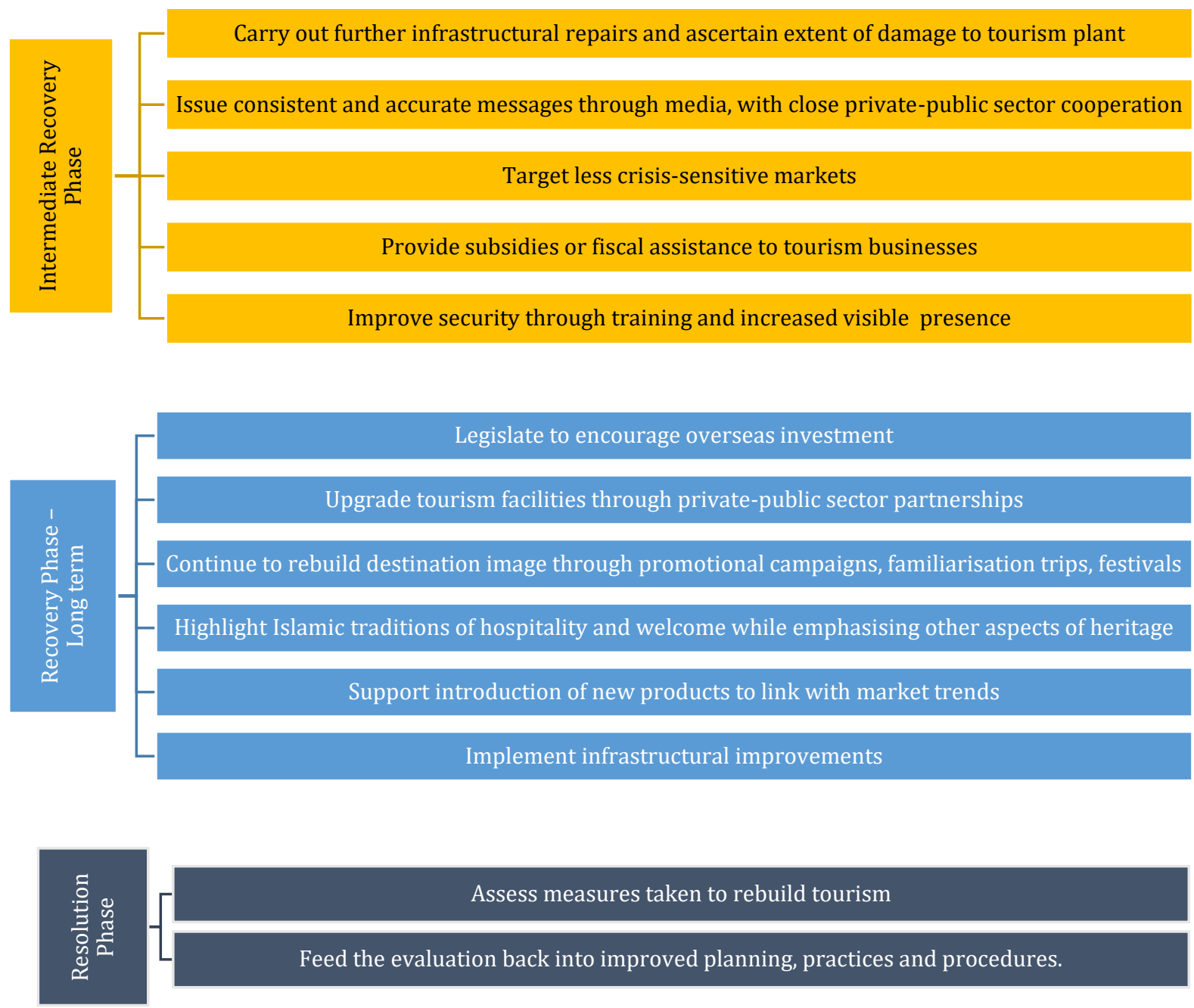

\section{Assess measures taken to rebuild tourism}

Feed the evaluation back into improved planning, practices and procedures.

Based on UNWTO, 2011; Faulkner, 2001 


\section{Case Studies}

A series of eight case studies were conducted on countries which have encountered challenges to their tourism sectors in recent years. The case studies were carried out by desk research or by desk and field research and included four OIC Member States (Indonesia, Turkey, Tunisia, The Gambia), and four non-OIC countries (South Africa, the United Kingdom, Thailand, Sri Lanka). An outline of the principal successful responses taken by the various countries is given below, grouped under the headings of pre-risk and crisis management, market responses, destination responses, and critical success factors.

\section{Pre-risk and Crisis Management}

- Creating a tourism-specific crisis management plan (by the tourism authorities) which integrates with the national-level disaster preparedness planning.

- Enterprise-specific risk awareness and crisis management planning.

- Establishing good relations with media and travel trade in order to ensure good support in the event of a crisis.

- Good communications and relations between stakeholders, e.g. horizontal communications between industry members and vertical communications between government and industry.

\section{Market-oriented Responses}

- Setting up a centralised hotline in the immediate aftermath of a crisis to answer media/ trade / tourist enquiries. The most successful users of this tactic gave consistent and accurate messages, since attempts to gloss over the truth are quickly uncovered by journalists and individual tourists.

- Familiarisation trips for journalists, bloggers and tour operators.

- Immediate refunds for people who wished to cancel their visit in the light of the crisis; offers of price reductions (for potential travellers) or accommodation upgrades (for people already booked or in-country).

- Building the destination's image through sponsorship; seeking and promoting 'good news' or unusual stories; co-creation of destination image through visitor contributions, especially through social media; funding bloggers to write about the country; engaging PR agencies.

- Market diversification, especially appealing to less sensitive markets, for instance regional markets which are more likely to understand the situation better, and/or other Islamic countries by crisis-afflicted Islamic countries.

- Appeals to the resident population or diaspora to holiday in-country.

- Increased budget for marketing, sometimes linked to a 'Visit [name of country] Year' or a specific theme.

- In the mid to longer term, a thorough understanding of market trends was felt to ensure a speedier and more appropriate response to crisis. 


\section{Destination Responses}

- Introduction of crisis or disaster management plans and action plans (if not already in place), at national level and local level and by the public sector and individual businesses.

- Tax holidays or subsidies, reduction in costs such as landing fees or visa fees, government grants to tourism businesses.

- Direct funding by government and development agencies for re-building or upgrading infrastructure in the short-term, and for capacity-building in the medium to longer term.

- Product diversification, integrated with market diversification to reduce reliance on a narrow range of products and services.

- Improved security on the ground and on flights (visible to travellers and behind the scenes).

- Loosening of visa regulations, making applications easier, or reducing the cost.

- Close collaboration by government authorities with other stakeholders.

- Good communication between the tourism industry and local community to ensure their support for tourism.

\section{Critical Success Factors}

- Where countries (or destinations) already have a robust tourism industry with strong underlying USPs, good recognition as a brand, and good customer loyalty (e.g. a high level of repeat visitors and warm links between visitors and local people), it is more likely that recovery from crisis will be swift. In some cases tourists who feel a personal connection with a country will donate money for its recovery (especially in the case of a natural disaster), and make a point of visiting in order to support the industry.

- The most successful recovery has been evidenced where there is strong government commitment to the industry as well as leadership in terms of strategy, policy, and understanding of market trends.

- Recovery has also been helped where there is clear evidence of public and private sectors working together and supported by the general public.

- Deregulation of over-bureaucratic procedures and introducing incentives for encouraging foreign investment.

- Looking to the longer term, some governments have introduced training programmes to build human resource capacity generally across the sector. 


\section{INTRODUCTION}

International tourism amounted to 1,235 million overnight arrivals in 2016, a growth of 3.9\% over 2015. International tourism receipts grew at a similar pace, increasing by $2.6 \%$ over 2015 to US\$ 1,220 billion in 2016 (UNWTO, 2017). It represents 7\% of the world's exports in goods and services. Future growth in international tourism is expected to be between 3 and $3.5 \%$ a year to reach 1.8 billion arrivals by 2030 (UNWTO, 2016).

However, tourism is a unique item of international trade in that it takes place in places other than the tourist's home country, with tourists' image and knowledge of destinations frequently based on destination and travel trade marketing, and word-of-mouth or social media reports. This means that any destination's market potential is susceptible to negative change in the event of individual bad experiences reported on social media, or a wider event that limits tourist activity from functioning as expected. It is increasingly common for destination stakeholders - both public and private - to formulate policies and strategies to avoid such risks and counter any crises that occur. Many destinations already have plans in place to ensure rapid responses in order to restore their tourism sectors to normal operations.

Another characteristic that marks tourism out as different from most other forms of trade is that it comprises a multiplicity of organisations and interests, with each tourist trip involving elements from various sub-sectors including:

- Accommodation - large, medium and small hotels, self-catering villas, hostels, 'Bed \& Breakfast' establishments, caravan parks and campsites

- Food \& Beverage - restaurants, cafes, hotel dining-rooms, fast food outlets, bars, streetfood stalls

- Transportation - air carriers, bus companies, car rental, taxis, marine and river transport, cruise lines,

- Entertainment - nightclubs, casinos, cabarets, theatres, concert venues, shops

- Attractions - theme parks, museums, galleries, cultural heritage/historical sites, gardens, amusement/recreation parks, sacred sites, interpretative centres, national parks and other protected areas

- Travel Trade - travel agencies (including online), tour wholesalers, ground handling agents / inbound agents, tour operators (including specialists), and tour guides

- Festivals, Events and Conferences - carnivals, sports tournaments, meetings/conferences/ conventions, festivals, trade shows, fairs \& exhibitions.

- Other Tourism Services - government tourism departments, Tourist Information Centres, research services, reservation services, advertising agencies, trade press, insurance, marketing professionals, professional associations, consultants, tourism academics 
All these sub-sectors are sensitive to crises and the interests of each need to be protected through coordinated and collaborative destination strategies and actions. As Laws and Prideaux (2005, p.1) pointed out, "crises can occur at any level of operation including an individual restaurant or a local coach company, a destination, a region, nation or the global tourism industry".

The topic of risk and crisis management has been examined and strategies and action programmes developed by numerous international agencies, regional groupings of countries, individual nations and areas within countries, as well as by the private sector, both collectively (either within an area or as a trade grouping) and individually. This study incorporates many of the guidelines and approaches produced by these organisations as well as relevant academic literature. The key documents covering regional groupings of countries, or providing guidelines applicable to risk and crisis management internationally, are:

- UNWTO (2011) Toolbox for Crisis Communications

- PATA (2011) Bounce Back - Tourism Risk, Crisis and Recovery Management Guide

- UNEP in collaboration with CAST - Caribbean Alliance for Sustainable Tourism - (2008) Disaster Risk Management for Coastal Tourism Destinations Responding to Climate Change

- ASEAN (2015) Tourism Crisis Communications Manual

- UNEP (2008) Climate Change Adaptation and Mitigation in the Tourism Sector: Frameworks, Tools and Practices

- UN (2015) Tourism and Disaster Risk. UN contribution to the consultation leading to the Third UN World Conference on Disaster Risk Reduction

- UNEP APELL (2015) Awareness and Preparedness for Emergencies at Local Level

- UNEP APELL (2007) Disaster Risk Reduction in Tourism Destinations

- OAS in collaboration with CDERA - Caribbean Disaster Emergency Response Agency (2009) Multi-Hazard Contingency Planning Manual for the Caribbean Tourism Sector

- CRSTDP - Caribbean Regional Sustainable Tourism Development Programme Caribbean Tourism Organization (2008) Good Practices: Natural Hazard Risk Management in the Caribbean Tourism Sector 


\section{Methodology}

Initial research for the report was carried out using secondary sources available through academic and professional databases, including accessing recent and key articles and reports from leading academic journals and tourism organisations such as those listed above. The findings of the literature review were illustrated and enhanced by a multi-stage approach to eight case study countries. This phase of the study included further secondary research into relevant academic papers and professional reports relating to the case study countries, field trips to four of the countries, and interviews with key informants both in these countries and in the case of case study countries which were not visited. The findings of both the overall literature review and case study review were triangulated by carrying out a survey of tourism businesses and organisations located in the eight case study countries.

\section{Organisation of the Report}

The report will cover conceptual aspects of risk and crisis management (Section 1), implementation strategies (Section 2), crises in OIC countries and how they have been handled (Section 3), detailed case studies of crisis management in OIC countries (Section 4) and in non-OIC countries (Section 5). Section 6 will give conclusions and recommendations based on the preceding sections. 


\section{CONCEPTUAL FRAMEWORK: Risk and Crisis Management}

Risk and Crisis management is an integral component of overall tourism and hospitality management. It is (or should be) practised at destination level by public sector agencies and communities as well as by larger commercial organisations (at destination level) and by individual businesses.

Before establishing a framework which explains and guides the stages of anticipating, responding to and recovering from events that negatively impact on tourism operations, the key terms will be defined. The remainder of this section will cover the principal concepts involved in the management of risks and crises in the tourism sector, including the tourism resilience cycle and business resilience, different types of crisis which can affect tourism and their impacts, and the principles of crisis communications including the role of media and travel advisories.

\subsection{Crisis and Disaster}

Crises are periods of intense uncertainty characterized by unpredictability and loss of control over key functions of systems (Moreira, 2007). Generally, a crisis affecting the tourism sector manifests as an event or set of circumstances which compromise or damage the market potential and reputation of a tourism business or an entire region (PATA, 2011). Some authors (e.g. Faulkner, 2001; Moreira, 2007) distinguish between a 'crisis' and a 'disaster', with the key differences being that crises tend to be more predictable, caused by anthropogenic action, evidencing an observable build-up, and of longer duration; while disasters tend to be more sudden, less predictable, caused by natural forces, and generally shorter in duration. Disasters are likely to give rise to emergencies, in other words rapidly evolving incidents requiring an immediate response.

In this report the term 'crisis' will be used to cover both crises and disasters, although the term 'disaster' will also be used when it is utilized by our sources and for natural events. In each case (whether a natural disaster or anthropogenic crisis), the events demand policies, decisions and counter-measures to limit the extent and duration of the negative consequences (UNWTO, 2011).

In terms of predictability and avoidance, there are two broad categories of tourism-related crisis: those beyond the control of managers (either in the public or private sector), and those resulting from a failure of management to put in place contingency measures to deal with predictable risks.

\section{Category 1: Outside management control}

Crises outside management control include natural disasters, epidemics, and sudden global economic events. 


\section{Category 2: Management Failure/Lack of Contingency Planning}

Crises can occur within the business or at the level of a region or country, and include (within the business) collapse due to management shortcomings, financial fraud, loss of data, destruction of place of business due to fire or flood without adequate back-up procedures or insurance cover; and (at the level of a region or country) acts of war or terrorism, political upheavals, crime waves, and anthropogenic climate change.

\subsection{Risk Management}

Effective risk management can prevent an issue from becoming a crisis. Poor understanding and management of risks can lead to a crisis situation. Risk management involves assessing the probability of negative events that may lead to the tourism sector being unable to operate normally. As will be seen from the case studies in Sections 4 and 5, destinations face a range of risks, some of which are beyond the control of management while others are due to management shortcomings or can be mitigated by crisis mitigation planning.

The stages of the process are illustrated by the model of disaster risk management developed for natural disasters in the Caribbean, as shown in Figure 1.1. The stages of preparedness, response, and recovery take place against a background of technical and hazard knowledge and planned responses.

\section{Figure 1.1: Disaster Risk Management Strategy}

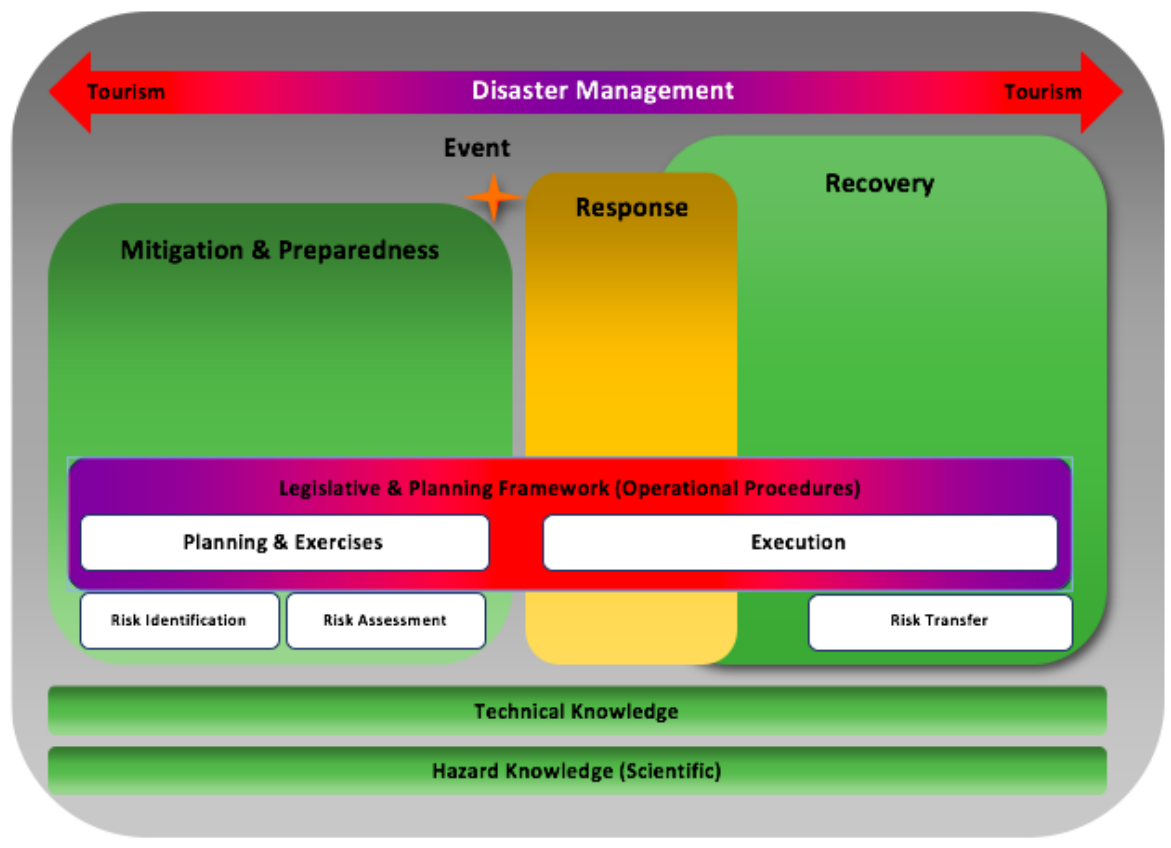

Source: adapted from workshop on Disaster Risk Management Strategy for Tourism in the Caribbean, May 2009 
Six functions of risk management were identified by PATA (2011):

1. Identify: Identify risks or hazards before they become realities.

2. Analyse: Create decision-making information by evaluating the probabilities, time-frames and potential impacts of each risk and then classifying and prioritising them.

3. Plan: Use the decision-making information to formulate contingency action plans for mitigating the potential impact of each risk.

4. Track: Monitor the likely effectiveness of these plans by reviewing data on evolving risks.

5. Control: Revise the risk mitigation plans according to data from the tracking stage.

6. Communicate: Implement internal and external information policies to ensure stakeholder buy-in and support in monitoring changes in the risk environment.

The specific risks and crises likely to occur within tourism systems will be outlined in Section 1.4 below. However, a more nuanced view on crisis management is also necessary. Scott et al (2008) claim that the standard perspective of recovery based on a series of remedial steps leading to normality is inadequate. Instead, a more evolutionary perspective is needed based on the presumption that there is no unique solution to a crisis. This form of analysis focuses on the effects of a crisis on operations, relationships with network partners, the ways in which these develop as responses to the crisis, and the emergence of new states of operation based on organizational learning. These factors are fundamental to an understanding of the emerging discourse of resilience, which are considered below in the context of tourism.

\subsection{Tourism Crisis Management Frameworks}

A crisis is "an event, in whatever form it occurs, that creates a shock to the tourism industry resulting in the sudden emergence of an adverse situation" (Laws and Prideaux, 2005, p. 1), while crisis management is the "strategies, processes and measures which are planned and put into force to prevent and cope with crisis" (UNWTO, 2011). This process involves understanding how businesses react to crisis, what measures need to be taken and what effect these will have.

Most crises cannot be predicted and many cannot be avoided, meaning that no destination is immune from them (Faulkner, 2001). Tourism managers and researchers therefore need to understand the potential nature and crises and their likely development and possible magnitude. Faulkner (2001) proposed a framework for understanding the phases of a crisis and the responses necessary from stakeholders. ${ }^{2}$ The framework specifies 6 stages, as shown in Table 1.1, which fall into three overall stages which relate closely to the iterative phases of the planning cycle (i.e. plan strategies, implement actions, evaluate success, revise plan).

\footnotetext{
2 The framework is normally known as 'Faulkner's Tourism Disaster Management Framework', but in keeping with the nomenclature outlined earlier in this report, the term 'crisis' will be used to cover the range of natural disasters and anthropogenic situations which can occur.
} 
Table 1.1: Crisis Management Framework

\begin{tabular}{|l|l|l|l|}
\hline No. & Stage & $\begin{array}{l}\text { Principal strategies \& actions } \\
\text { Contingency planning }\end{array}$ & $\begin{array}{l}\text { Key stages } \\
\text { Prevention, based on } \\
\text { known information }\end{array}$ \\
\hline 1 & Pre-event & $\begin{array}{l}\text { Prodromal (onset of } \\
\text { crisis situation) }\end{array}$ & $\begin{array}{l}\text { Initiation of contingency plan } \\
\text { Response }\end{array}$ \\
\hline 3 & $\begin{array}{l}\text { Emergency } \\
\text { Intermediate }\end{array}$ & $\begin{array}{l}\text { Protective actions during crisis } \\
\text { Short-term needs addressed, clear } \\
\text { communication strategy in place }\end{array}$ & $\begin{array}{l}\text { Response } \\
\text { Response }\end{array}$ \\
\hline 5 & Recovery & $\begin{array}{l}\text { Recilding/restoring infrastructure, } \\
\text { foordinated and sustained }\end{array}$ & Stimulation of recovery \\
\hline 6 & Resolution & $\begin{array}{l}\text { Review of actions taken to feed into } \\
\text { further contingency plans }\end{array}$ & $\begin{array}{l}\text { Prevention, based on new } \\
\text { learning }\end{array}$ \\
\hline
\end{tabular}

Based on Faulkner (2001)

It should be noted that the duration of crises can vary considerably. Some can be of rapid and unexpect occurrence, such as with an earthquake, while others can be much slower to build up. In both cases the effects can be sustained: in the case of natural disasters the infrastructure can take many years to rebuild, while in the case of political and societal upheaval the physical infrastructure may be relatively undamaged, but the 'soft' infrastructure of institutions and business networks can take a long time to regain their essential functions. Faulkner's framework is flexible enough to cover all of these eventualities and will be used to structure Section 2 of this report on developing mitigation strategies and actions to address the different stages of the crisis as it builds and subsides.

Crisis management planning entails establishing structures to develop policies and courses of action to be taken in the event of a crisis, and covers arrangements and procedures according to the six stages of a crisis developing. The actions to be taken essentially fall into three overall phases, as shown in Table 1.1 above (more detailed of actions to be taken are given in Section 2):

\section{Prevention - crisis management body, plan, procedures}

Though many crises are unexpected (especially natural disasters), governments and businesses can protect themselves from the worst consequences by establishing a multi-representative body to assess the potential risks and establishing policies and procedures to deal with any consequences of the crisis. At this stage a crisis response plan will be prepared, both in the form of written procedures and by training key personnel.

\section{Response - delivery of the plan and procedures}

When a crisis event occurs, the key factors in the early stages are a rapid and coordinated response of the destination tourism authorities and operators, particularly in respect of assessing the severity of the crisis and ensuring the safety of tourists and residents, followed by actions to minimise the medium- to longer-term consequences and facilitate recovery from the situation. 


\section{Recovery Stimulation}

Even when the immediate crisis is over, the market can remain sceptical as to the safety of the destination/facility, so positive actions need to be maintained over a period of time through longerterm renewal of infrastructure and through reassurance marketing.

\subsection{The Tourism Resilience Cycle}

\subsubsection{The Resilience Cycle}

Resilience is the ability of a system to reduce the chances of a crisis occurring, to absorb the impacts of a crisis or disaster should it occur, and to recover quickly. Another way of looking at resilience is the preparedness and ability of systems (in tourism and other fields) to respond to, cope with and adapt to changes over time without losing their fundamental structures and functions (Buultjens et al, 2015). The fundamental principles of resilience, based on the work of C.S. Holling (2001) and others, are that:

1. systems do not evolve in a linear fashion but according to a cycle or loop,

2. the phases of the cycle broadly repeat, but the characteristics of each repetition are not necessarily identical,

3. the features and speed of recovery after a destabilising event depend on the system's adaptive capacity (or vulnerability), and

4. adaptive capacity is based on various forms of capital accumulated during earlier phases and iterations.

Another way of viewing resilience is that systems fluctuate within what Walker et al (2004) calls "basins of attraction". The bottom of the "basin" is the point at which systems are strongest with a margin on each side within which systems can fluctuate without losing their inherent function. If a dramatic stress event occurs, it may cause the system to override the margins of its "basin" and pass into a different state. The way systems switch and regain stability can be illustrated as a figure-of-eight, with the four principal stages forming a repetitive loop (Figure 1.2).

Figure 1.2: The Resilience Cycle or 'Holling Loop'

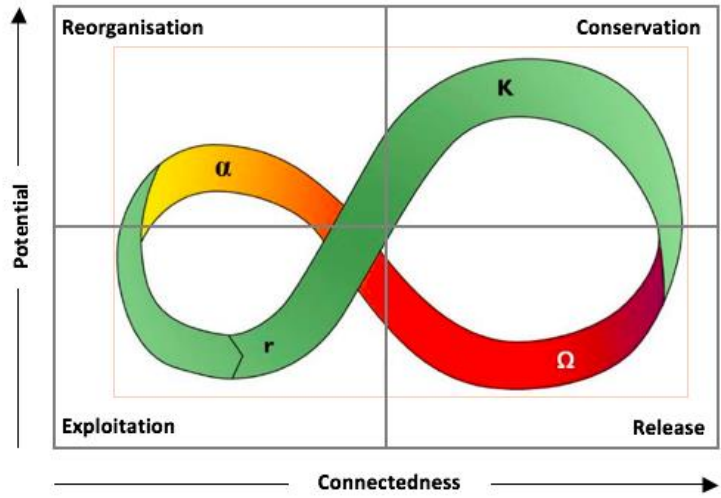

Source: Holling (2001) 
The four phases were explained by Holling (2001) as follows:

$\alpha$ : $\quad$ Reorganization: rapid change after a destabilizing event, with regeneration and renewal of societal structures.

$r$ : $\quad$ Exploitation: new systems are created through exploitation of social and other forms of potential produced in previous phases. New institutions may emerge and new political, cultural and social relationships form more easily.

$K$ : Conservation: the gradual construction of a new stable state, when structures are institutionalized and new capital is formed. Structures can become increasingly interconnected, leading to rigidity and inflexibility.

$\Omega$ : Release: a disturbance event (or series of events) which destabilizes existing systems, releasing the rigidity of structures and leading to the rapid changes.

There is occasionally a very clear demarcation between one phase and another, for instance in the case of a major natural disaster or political disturbance which disrupts normal systems, but more often there is no clear dividing point between the stages, with one evolving gradually into another.

\subsubsection{Resilience Theory in Tourism}

Cochrane (2010) explains the operation of resilience theory in tourism. A system which renews itself after a destabilising event - the "reorganisation" phase - moves into the "exploitation" phase with the appearance of an orderly system through making use of various forms of potential (i.e. social, human, natural, financial) developed over previous cycles, and channelling these into new structures. This is followed by the longer "conservation" stage in which the different forms of capital again build up. The system becomes increasingly conservative, interconnected and, therefore, stable - though flexibility is needed to ensure the system does not become rigid and incapable of absorbing stress. When a destabilising event occurs, the "release" phase utilises stored capital to readjust to the collapse of the old system and lead to another "reorganisation" phase.

Using resilience theory as a framework, the factors that cause vulnerability in systems, as well as those that improve the system's capacity to absorb disturbance, can be analysed. Vulnerability to unexpected events reflects three categories of sensitivity factors:

- Physical, social or institutional exposure to stress,

- Sensitivity to the stress or deviation including the ability to anticipate and cope with it, depending on political, social and institutional characteristics, and

- The ability of the system to recover, based on existing structures and to adapt these structures to withstand future deviations more successfully i.e. resilience. 
Understanding the factors of vulnerability, stress and resilience can help to identify the necessary interventions to enable a system to maintain its essential functions, while understanding the fluctuations within a system can enable mechanisms to be incorporated to better predict possible disturbances and accommodate their impacts, thereby strengthening structures to allow faster and more successful regeneration. Resilience principles take further the phases of Faulkner's crisis management framework in that Stage One (Pre-event) relates to the latter stages of the 'Conservation' phase, when firm societal and institutional structures are in place; Stage Two (Prodromal) relates to the 'Release' phase of the disturbance event, or crisis; Stages Three and Four (Emergency and Intermediate) relate to the 'Reorganization' phase of rapid change and regeneration of structures; Stage Five (Recovery) relates to the 'Exploitation' phase of new systems being created based on the social, political and institutional capital built up before the crisis; and Stage Six (Resolution) relates to the early stages of the 'Conservation' phase, when a new stable state is formed.

Resilience theory is increasingly widely applied in tourism, with its introduction to tourism academia notably by Farrell and Twining-Ward (2004; 2005). Since then, the concepts have been used in a number of contexts. For instance, in the context of case study countries studied for this report, a resilience and vulnerability analysis was carried out by Calgaro and Cochrane (2009) to examine the social and political dimensions of tourism recovery in Thailand and Sri Lanka after the 2004 tsunami (see also Section 5).

\subsubsection{Tourism Business Resilience}

More recent studies have examined organisational resilience in the tourism sector (Orchiston et al, 2015), the resilience of formal and informal tourism enterprises to disasters (Biggs et al, 2012), and how local tourism business can build resilience in unpredictable business environments (Dahles and Susilowati, 2015). As explained by McManus et al (2008), enterprise resilience is viewed as a combination of financial capital, social capital and lifestyle benefits. Together, these allow the enterprise to fulfil its core functions of providing a product or service to consumers while providing a livelihood for employers and a return on investment for owners and shareholders.

The two principal aspects of organisational resilience are 'planned' and 'adaptive' resilience. Planned resilience is the existing planning capacity within an enterprise which enables it to ensure business continuity and undertake standard risk management initiatives, while adaptive resilience is the ability of an enterprise to respond successfully to a crisis. This is often an expression of strong leadership and organizational culture, which enables organisations to respond effectively to situations as they occur (Orchiston et al, 2015). 
Using data from tourism organisations in Canterbury, New Zealand, surveyed 18 months after the 2010 earthquake, Orchiston et al (2015) found that an additional highly rated factor in organisational resilience was the ability to collaborate with key stakeholders, which allows businesses to work across organisational boundaries, make collective decisions with other stakeholders (including competitor businesses), and work effectively with other organisations. A further finding was that businesses must be able to respond to changes in the tourism landscape. These factors were also highlighted by Cochrane (2010) in her model of the 'Sphere of Tourism Resilience', which suggested that the three key elements in the capacity of businesses and tourism systems to recover quickly from crises were strong leadership, an ability to harness market forces, and good collaborative working.

\subsection{Types of Crisis in Tourism}

The UNWTO (2011) identifies five types of crisis impacting the tourism sector at national, regional or local level. These are: (1) environmental crises, including geological, extreme weather, and human-induced events; (2) societal and political events; (3) health-related crises; (4) technological incidents or failures; and (5) economic events.

In addition, specific events may affect individual businesses, such as (6) accidents or incidents in the public realm (e.g. death or injury of individual tourists due to drowning, falls, traffic accidents, or crime), or (7) accidents or events within an individual business: (e.g. food poisoning, accident on the premises, a fire in the kitchen or room, hostility between different client groups, in-house malfunctioning of IT systems, problems with power or water supply).

These aspects will be covered in the next sections, though it is important to recognise that in many cases there is overlap between the different types. Some environmental crises (for instance floods, landslides) have anthropogenic origins: for instance the devastating mudslide in the Sierra Leone capital, Freetown, which killed around 500 people in August 2017, was thought to be due to years of deforestation in the hills around the capital, and there are obvious linkages between economic events and societal and political events, in that economic issues such as devaluation and unemployment can spark societal unrest and political challenges. Nevertheless, it is helpful to have a form of categorization and the one devised by UNWTO is applied here. It will be referred to throughout the report.

Examples given in this section are mainly drawn from countries other than those included in the case studies covered in Sections 4 and 5.

\subsubsection{Environmental Crises}

Geological: Events in this category include hurricanes and cyclones, earthquakes, volcanic eruptions, and tsunamis. 
Although the likely path of certain extreme weather-related events, such as tropical storms, can be tracked and precautions taken to move tourists to safe locations, many types of geological event cannot be predicted. Depending on where they occur and where their impacts are felt, significant geological events are likely to cause major disruption in the normal operation of tourism operations: infrastructure, communications and facilities can be damaged and rendered nonoperational, and power and water supplies can suffer outages. These will present challenges in evacuating tourists out of the affected areas and uncomfortable conditions for those who remain.

Significant geological events affecting tourism in recent years include:

- The Indian Ocean tsunami of December 2004 which affected 11 countries, most severely Indonesia, Sri Lanka, India and Thailand, with over 230,000 fatalities.

- The Nepal earthquake of April 2015 in which nearly 9,000 persons died.

- The March 2011 offshore earthquake and tsunami that caused the loss of 22,000 lives and crippled the Fukushima Daiichi nuclear plant on the east coast of Japan.

Extreme Weather: events in this category include hurricanes, floods, and prolonged drought. Examples include:

- Hurricane Katrina and the extensive flooding in New Orleans in 2010, with the loss of over 1,800 lives.

- Wildfires in natural areas brought about by lightning strikes or human activity, for instance the fires around Gatlinburg, Tennessee, in December 2016 which resulted in 14 deaths and widespread destruction of tourist facilities, or the fires in Portugal in June 2017 which killed over 60 people.

Anthropogenic: The principal human-induced environmental events are climate change, pollution (of air and water), and deforestation.

Many nations or countries with significant low-lying areas identify climate change as one of the biggest threats they face in respect of their tourism industry. For instance, a study of the vulnerability of the tourism sector to climate change conducted in the Maldives found that over three-quarters of tourism businesses believed that climate change would be detrimental to their business, impacting most severely on diving and snorkeling because of sea-level rises and coral reef bleaching (Maldives Ministry of Tourism, 2013), while in Australia, severe bleaching of coral along the Great Barrier Reef due to warmer ocean temperatures is causing concern that tourists will be deterred (Arup, 2016).

\subsubsection{Societal/Political Events}

Societal and political events affecting tourism include crime, politically motivated disturbances, terrorism, wars, and human rights abuses. A growing concern is when threats are perpetrated by external influences, especially when added to domestic unrest. 
Crime: Where a country has high levels of crime, particularly physical attacks targeted at tourists, there will understandably be a reluctance to visit. In 2008, South Africa's tourism minister claimed that the country's spiralling crime figures may have deterred more than 22 million tourists from visiting the country over the previous five years (Starmer-Smith, 2008) and, as will be seen in the South Africa case study in Section 5.1, the perception of crime is still a significant deterrent to some visitor markets.

Politically-motivated disturbances: The developments from 2010 across the Middle East and North Africa caused concern about the safety of tourists and led to tourism businesses in affected countries either evacuating their clients or providing reassurance to intending visitors in order to prevent cancellations. Avraham (2016) reports that in Egypt, the industry and government emphasised that the area of disruption was limited, since the protests were centred in Cairo, while other parts of the country (including the Red Sea resorts) were unaffected and tourism was functioning normally.

Extreme examples of politically-motivated disturbance manifested through coups, civil war and acts of terrorism will generally bring inbound tourism to a virtual halt, since it normally leads to travel warnings issued by source country governments (although see the example of Sri Lanka, which experienced a long-running civil war, in Section 5.4). Normal tourism operations can only recommence with the restoration of stability and lifting of the travel advisories.

Terror attacks mounted by disaffected interests within society are typically targeted at capital and other major cities and transportation systems in order to achieve maximum disruption. Examples resulting in multiple fatalities include the London transport bombings in 2005, the Ankara railway station attacks in October 2015, the St Petersburg metro system bombs in April 2017, and the bombing at the Manchester Arena in May 2017.

If the targets for terrorist attacks are foreign tourists, the resumption of international tourism will generally be a lengthy process. In the survey of tourism businesses carried out for this report, terrorism was cited as the most significant event to impact on tourism in respondents' countries. Measures to speed up the process of recovery are discussed in Section 6; see also the Tunisia case study in Section 4.3.

Human rights abuses: Where significant political repression and human rights abuses are perpetrated against domestic populations, international tourism will be negatively affected if there is widespread media coverage and lobbying against tourism by pressure groups. 
External threats: A growing type of threat is terrorism whose roots are external, especially when this combines with internal unrest.

\subsubsection{Health-related Crises}

Health-related crises affecting tourism in recent years include Avian flu, Foot and Mouth Disease, SARS, salmonella, and Ebola. There are two broad categories of health-related crises affecting tourism: (1) macro-level epidemics affecting people across a wide area, and (2) micro-level localized illness affecting smaller numbers of tourists.

1. Macro-level epidemics are outbreaks of disease that threaten both the resident population and visiting tourists, e.g. SARS (Severe Acute Respiratory Syndrome), H5N1 and H7N9 (Avian flu), both of which originated in China and affected Asian, Middle East and African countries, and the 2014-2016 Ebola outbreak in West Africa. In some cases the outbreak does not affect tourists directly but impacts on their ability to enjoy their holiday as planned, such as with the outbreak of Foot and Mouth Disease in the UK in 2001: this will be discussed in detail in Section 5.2.

2. Micro-level events include illness resulting from poor hygiene or safety by service providers, e.g. outbreaks of food poisoning such as occurred on the Caledonian Star cruise ship in 1993 and at the Bahia Principe Hotel in the Dominican Republic in 2007.

For macro-level crises, the destination must prove that steps have been taken to eradicate the outbreak, or at least control it to the extent that travel to the destination is recognised as being safe by international health agencies such as the World Health Organization. For micro-level crises, affected businesses must demonstrate both to their own governments and the international tourist market that measures have been taken to rectify the failings that caused the outbreak in the first place. The public sector has a significant role in setting standards such as Food Safety and Hygiene and ensuring that public-facing enterprises adhere to these.

\subsubsection{Technological Events}

This category includes crises caused by technological events such as transportation accidents and the failure of IT systems. These can be cause by malfunctions in the technology or by human shortcomings in operating the technical systems.

The increased technical reliability of aeroplanes, ships and trains has kept the incidence of accidents involving these modes of transport to extremely low levels. For instance, over the period 20002009 in the United States, there were 46,901 deaths in road accidents compared to 1,474 deaths in aviation and maritime accidents combined (Savage, 2013). Despite this discrepancy, air transport accidents attract far greater media coverage than road accidents. Worldwide, there were 65 fatal air accidents in the ten-year period 2006-2015, representing a rate of 0.29 per million departures (Boeing, 2015). However, where flights are the subject of a terrorist attack, such as the 2015 downing of the Metrojet carrying Russian tourists back from the Egyptian Red Sea resorts with the 
loss of 224 lives, the same procedures to recover from the crisis are necessary as in respect of a terrorist attack; these measures will be discussed in Section 2 .

There has been a single major cruise ship accident involving fatalities since 2000 - the Costa Concordia in 2012 sinking in which 32 passengers and crew lost their lives. Rail accidents are more common, particularly in countries with low standards of track and equipment maintenance.

In the case of road transport, there is a possibility of tourists being caught up and injured in accidents, and hazards may be intensified in countries where regulatory standards are low especially - as Henderson, 2007, points out - where public transport systems are concerned.

In view of society's greatly increased mobility using all forms of transport, allied to the high safety record of international transportation, the occurrence of transportation accidents is rather low. As a result, the reaction of tourist markets to transportation accidents that do not involve aircraft tends to be less dramatic than for other types of crisis, particularly in cases where rescue and recovery efforts are conducted quickly and professionally, and when investigations into the cause are conducted with speed and openness.

\subsubsection{Economic Events}

Economic crises affecting tourism include global recessions, weak national economies, and sudden changes in exchange rates. All these can result in a loss of consumer confidence and alter the propensity to travel. Since the Millennium, the most significant economic event affecting international tourism was the 2008/09 financial crisis and subsequent global economic slowdown. This resulted in a decline in international tourist arrivals and receipts of $4 \%$ and $6 \%$ respectively in 2009, compared to 2008. All regions were affected, though some - particularly the Asia-Pacific and Sub-Saharan Africa - fared better than others. However, the downturn was short-lived: the UNDP \& ILO (2013) reported that in 2010 the tourism sector rebounded faster than expected, with a growth in international arrivals of $7 \%$.

Another form of economic crisis relates to the relative value of national currencies. When these are weak against those of the principal source markets, tourist flows tend to increase because tourists receive more for their money, while countries with strong currencies are viewed as uncompetitive by international tour operators and their customers. For instance, a significant influence on USEurope tourist flows is the relative exchange rates between the dollar and the euro (WTTC, 2016), and the low value of the pound against source market currencies was said to be the main factor in a rise in long-haul bookings to the UK from China (up 209\%) and the USA (up 19\%) in July/August 2017; on average the UK was 9\% cheaper for visitors compared to the previous year (Doward and McCrum, 2017). 


\subsection{Impacts of Crises and Recovery in the Tourism Sector}

\subsubsection{Impacts of Crises}

Any crisis in the categories reviewed above will damage the tourism sector's ability to operate normally, either because of damage to transport and other infrastructure and facilities, or because of the perception that the destination is unsafe. As Laws and Prideaux (2005) point out, a crisis affecting tourism will be quickly followed by a decline in visitor arrivals with a consequent loss of jobs, reduction in business turnover and profits, falling tax revenues for the government, and (in the case of a crisis of longer duration) a failure by overseas and domestic entrepreneurs to invest in facilities. This was confirmed by the survey of businesses carried out for this report, which stated that the fall in visitor numbers was the most significant impact of crises. Even an event of short duration can cause considerable financial losses: Hall (2010) observed that the eruption of the Icelandic volcano Eyjafjallajokull in 2010 caused losses of US\$ 1.7 billion because of week-long restrictions to flights over Europe.

Sensitivity to destination disruption differs between tourist generating markets and segments and according to the type of disruption, with different markets being more sensitive to different aspects, depending on their age, background and experience of travel (Liu et al, 2016). As shown in Figure 1.3, the survey carried out for this report indicated clearly that West European markets are thought to be the most sensitive to crises, followed by North America.

Figure 1.3: Sensitivity of tourism markets to crisis
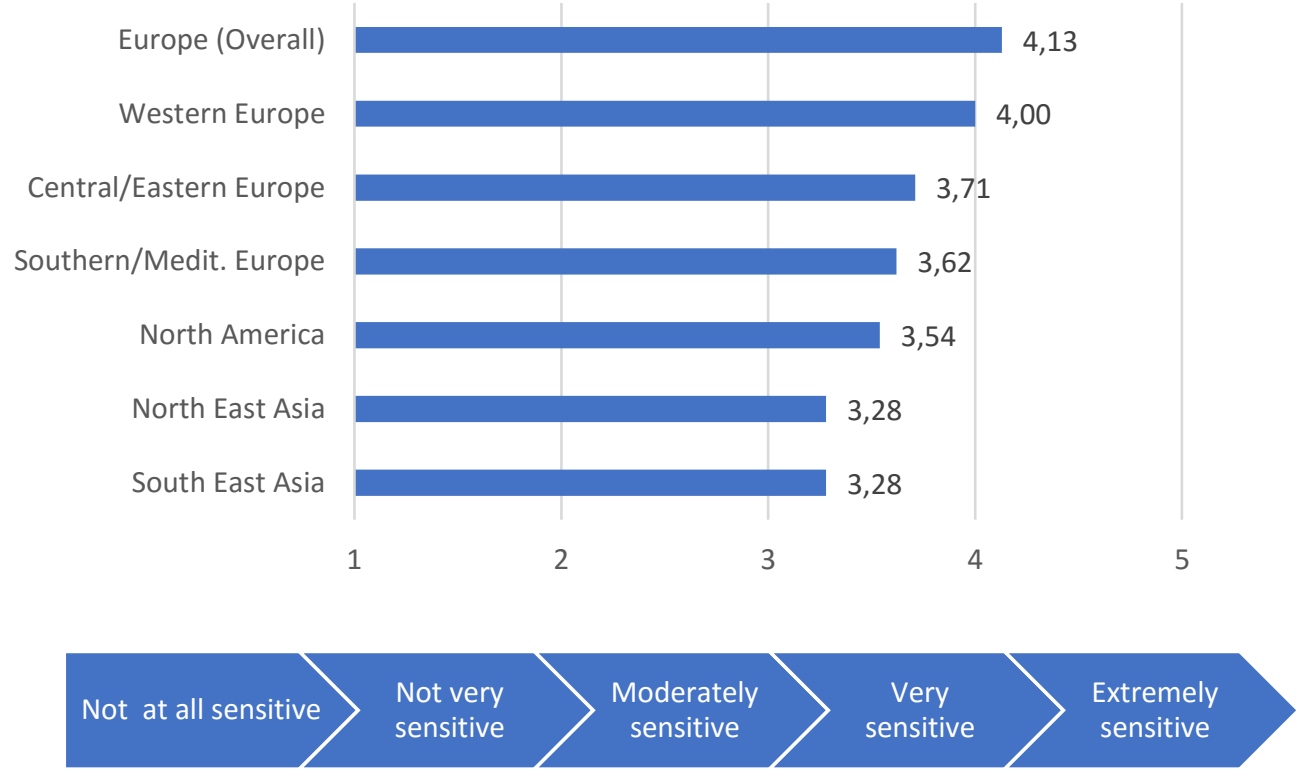


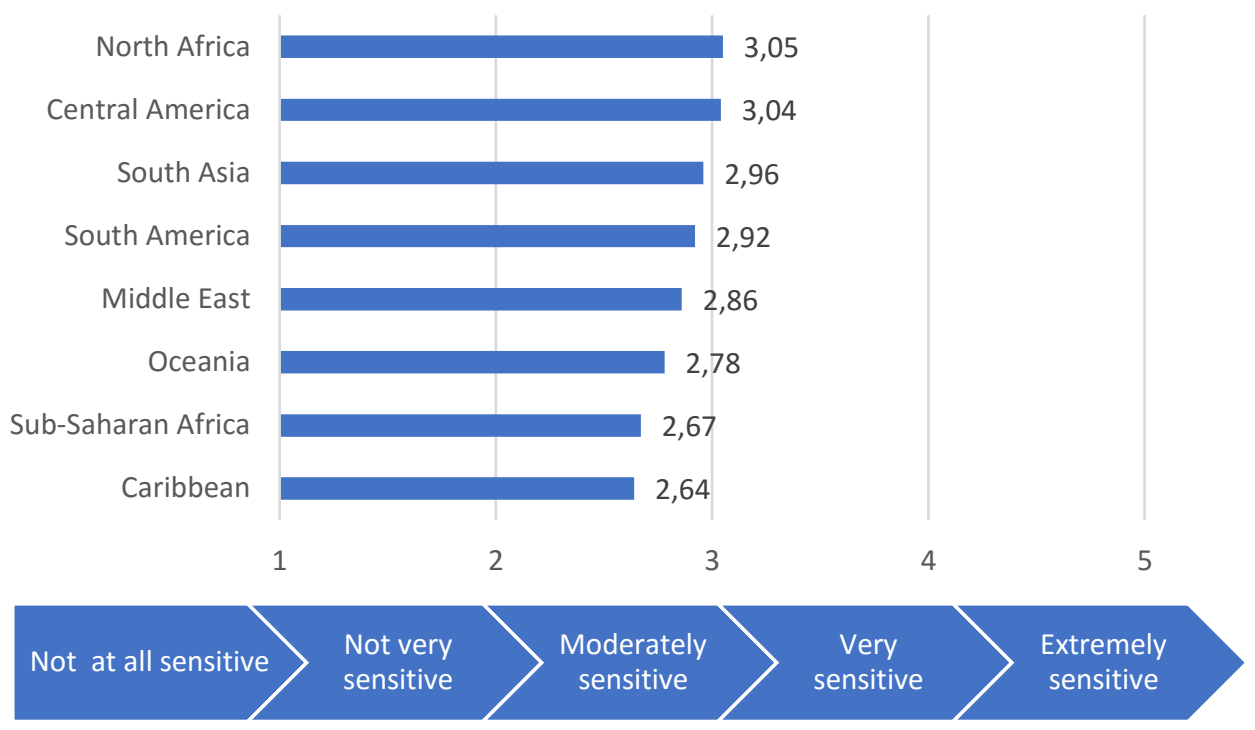

The survey also found that Asian markets were considered to be less sensitive. Misrahi (2016) notes that terrorist attacks - or even the threat of such attacks - are the most common cause of trip cancellations. This is because deaths from terrorist incidents have risen since 2000, with attacks becoming increasingly diverse in respect of locations targeted, the impacts created and the causes espoused by the perpetrators. A 2016 survey indicated that picking a safe and secure destination has become the priority for British holidaymakers, with $46 \%$ citing this aspect, ahead of 'value-formoney' at 33\%, while $14 \%$ of people were now more likely to take their holidays in the UK due to concerns about the safety of overseas travel (Torney, 2016).

As already mentioned, during the global financial crisis and economic downturn of $2008 / 9$, the tourism sector experienced significant decline and changes in travel habits, including a decrease in long-haul travel in favour of short-distance travel, especially intra-regional and domestic travel UNWTO \& ILO, 2013). Destinations with strong links to European and North American source markets were the worst affected, while countries with more diversified source markets were comparatively less affected. In terms of tourism segments, business travel suffered more than leisure travel because of the global decline in business activity.

In the case of natural disasters or one-off security-related incidents, potential travellers will often be alarmed by media reports and advised by their governments to avoid travel to affected areas. The natural tendency is to switch to alternative destinations offering higher levels of security. This can benefit neighbouring destinations, while the downturn is often short-lived and recovery can be fairly rapid, as shown above and as will be seen in the discussion of the case studies.

Significant crises invariably lead to reductions in tourist arrivals and revenue. Misrahi (2016) notes that the 9/11 attacks on New York led the US Government to close airports with thousands of flights cancelled; and even when they re-opened, flight demand was down by $30 \%$ during the initial shock period, and it took New York hotels 34 months to recover from the attacks. 
Apart from the direct costs of property damage and lost tourist income, there are indirect costs such as loss of employment and the diversion of foreign investment and short term capital flows, while the downturn in spending means that the destination's ability to repair damaged installations is in turn reduced as well as resulting in economic hardship for local people who depend on tourism. Estimates of the total costs of terror attacks range from US\$ 438 million for the 2013 Boston bombings to $€ 2$ billion for the 2015 attacks in France (Misrahi, 2016). Similarly, the 2011 earthquake affecting Christchurch, New Zealand, led to a drop of 73\% in international tourism demand (Orchiston et al, 2016), while the Bali nightclub bombings of 2002 resulted in a 50\% drop in tourist arrivals in the six months following the attacks, with one third of workers affected by job losses and three-quarters of hotel workers made redundant or put on reduced hours (Hajibaba et al, 2016). Further examples are given in Sections 4 and 5.

\subsubsection{Extent and Speed of Recovery from Crisis}

The question of whether crises have a 'beginning' and an 'end' is sometimes asked, but the answer is not straightforward. Clearly, when an event such as the Icelandic volcano eruption or the 2004 Indian Ocean Tsunami occurs there is little warning and the 'start point' appears obvious - except that with modern monitoring systems it is now often possible to predict unusual events in areas of significant tectonic activity. In the case of societal and political events there is often a build-up of tensions over a period, during which national crisis management agencies and tourism-specific bodies (both public and private sector) should be on the alert. Sadly, the increasing frequency of one-off terrorist attacks means that such institutions and enterprises need constantly to be on the alert. In the case of long-running crises, such as the civil war in Sri Lanka or the ongoing tensions in South Africa within government and between government and civil society, it is again generally hard to pinpoint a particular 'start' date, especially at the time of the crisis - even though later analysis may decide on a date, with the benefit of hindsight.

It is even more difficult to ascertain when a crisis is 'over', and rarely possible to do so. In the case of natural disasters it could be said that the crisis of 'over' when the infrastructure is rebuilt, displaced persons are rehoused, and tourism arrivals return to pre-crisis levels - but generally there will be some lingering memory of the disaster in people's minds, and the infrastructure is highly unlikely to be rebuilt in exactly its previous form. In 2003 a flash-flood devastated the tourism village of Bukit Lawang, in the Indonesian province of North Sumatra, with the loss of over 200 lives. The village had grown organically over three decades into a sprawling, unplanned mass of guesthouses and shops. After the event, the government took steps to allow reconstruction on a more planned basis, with additional river management works to ensure better flood control in the future.

In the case of terrorism or civil unrest it can take years for tourism numbers to return to normal. As will be shown in Sections 2 and 3, the duration of the effect of events may be of relatively short duration given appropriate remedial actions, including infrastructure repair, security improvements and reassuring communications. This can rectify the negative image and bring the sector back to normal operations within the short-to-mid-term, as will be seen in the case studies although where the context of the country is still seen as dangerous recovery is likely to take longer. 
Crises of longer duration may lead to a prevailing poor image and weak market perception as a desirable destination for discretionary travel. An example of this is Jordan, which although itself enjoying high levels of peace and security, is located in a region experiencing high levels of political turmoil and conflict (Oxford Business Group, 2015). On the other hand, Sri Lanka succeeded in retaining a successful tourism sector despite its long-running civil war.

Some commentators have linked the speed of recovery from crisis to the underlying stage of the destination on the 'Tourist Area Life-Cycle' curve, in that underlying growth patterns will soon recover if the trend has been upwards for some time before the crisis (Putra and Hitchcock, 2006). However, later analyses have determined that the speed of recovery lies in the various forms of capital (financial, human, cultural) built up in the pre-crisis period. Thus, countries with a wellestablished and diversified tourism sector which has strong participation from local stakeholders and local ownership as well as firm partnerships with tourism intermediaries (travel agencies, the media) and other international linkages are more likely to recover quickly than fragile destinations over-reliant on a narrow product offer and with an undiversified market base. Ghaderi et al (2012) report that tourism to the Malaysian resort island of Penang recovered within 4-6 weeks from each crisis encountered, while Carlsen and Hughes (2008) note that tourism to the Maldives from certain markets took just 3 months to recover after the tsunami (though other markets took longer). The rapid recovery was thought to be due to effective marketing campaigns, including familiarization trips for journalists, road shows and increased spend in major markets.

There is some disagreement on the recovery time needed for different types of crisis. Morris (2016) reports on research by the World Tourism \& Travel Council that destinations generally recover faster from a one-off, relatively small-scale terrorist incident than from long-running political turmoil or a serious environmental disaster (Table 1.2).

Table 1.2: Crisis Recovery Time

\begin{tabular}{|l|c|}
\hline Crisis Category & $\begin{array}{c}\text { Average Recovery Time } \\
\text { (months) }\end{array}$ \\
\hline Political Turmoil & 26.7 \\
\hline Terrorism & 13.0 \\
\hline Pandemic & 21.3 \\
\hline Environmental Disaster & 23.8 \\
\hline
\end{tabular}

Source: WTTC - World Travel and Tourism Council (2016)

However, the survey carried out for this study indicated that recovery times for individual businesses were significantly longer, taking an average of 4.7 years to 9.60 years to recover fully. As shown in Figure 1.4., the quickest events to recover from were political crises, followed by natural disasters, while disease epidemics and economic crises took the longest to recover from. 
Figure 1.4: Length of Time Taken for Own Organisation to Recover From Crisis

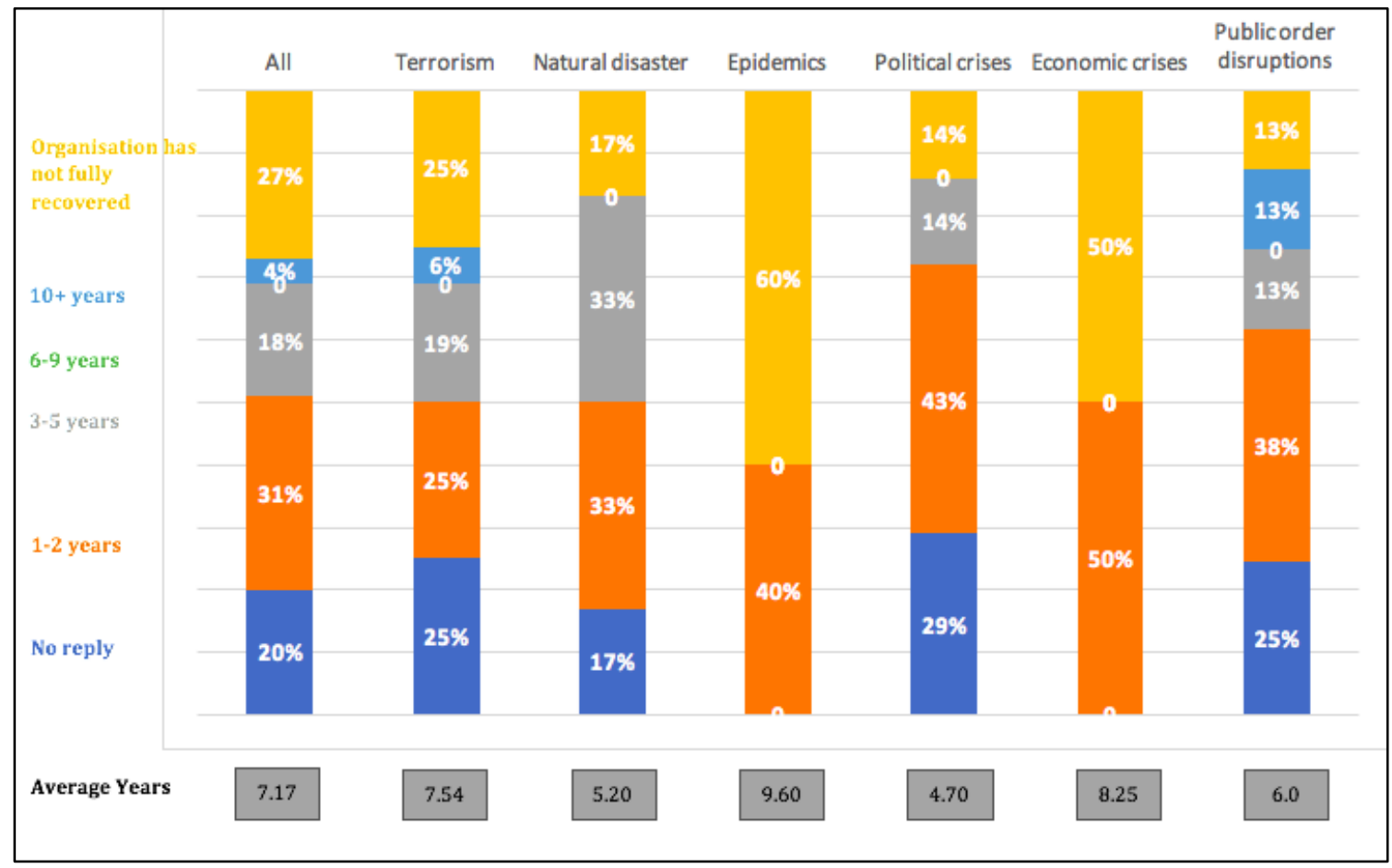

\subsection{The Role of Media and Travel Advisories}

\subsubsection{The Media}

The press and other forms of traditional media such as television and news agencies have significant influence on travellers' decision-making and on the recovery of tourism through reporting on the damage or suffering caused by natural disasters, terrorist attacks, disease outbreaks, or internal strife. In their investigation of media reporting on bushfires in Australia in 2013, Walters et al (2016) found that the desire to attract attention led to sensationalism and exaggeration, and concluded that the industry needed to take a proactive stance on countering such reports with accurate and honest accounts of the situation, as well as working cooperatively with the media to help them understand the impact of inaccurate reporting on the national economy and to file up-to-date and positive stories.

In another example, hoteliers in the northern Indian state of Uttarkhand blamed the national media's exaggerated reporting of localized landslides and flooding for a steep decline in tourism during the 2016 July season (Sharma, 2016), when mountain resorts normally benefit from domestic tourists seeking to escape the heat of the lowlands.

The mainstream media prides itself on rapid reporting of significant events across the globe, including most forms of tourism crisis - especially those affecting members of the media outlet's target audience. Graphic images of disasters or crises may be accompanied by harrowing accounts of human suffering and detailed accounts of extensive infrastructure and facility damage and destruction. Such images and reporting stays in the mind of the viewer long after the initial 
response period is completed and the recovery period is under way. In such instances, the reporting of the recovery programme tends to be less extensive because there is less visually exciting material. The images shown at the time of the incident are, therefore, not effectively counter-balanced in the travelling public's mind.

The expansion of user-generated content on social media such as Facebook, YouTube, Twitter, Instagram and TripAdvisor has changed the nature of communications by democratising the propagation of messages and images. The ability to communicate immediate reports, including graphic images, represents both a threat and an opportunity for destinations, particularly during and after a crisis. The threat is the risk of sensationalist reporting that exaggerates the scale of the problem supported by scenes of devastation and human suffering and the associated risk of 'fake news'. The opportunity is to respond rapidly with positive material on the limitations of the problem and the actions in place to assist those affected and make the necessary repairs to bring the sector back to normal functioning in the affected area. However, the distinction between 'traditional' media and newer forms is no longer as stark as it was: for instance BelairGagnon (2015) reports that the emergence of social media and the need to manage its material has led to a 'new media logic' in which journalists conversant with social media are now central to the newsroom, resulting in the integration of far more forms of media than previously as well as a more interactive relationship with the audience.

Government and private sector organisations are becoming adept at using all channels to promote positive messages during the recovery period. After the 2015 earthquake, Nepal used a digital campaign on social media to help it recover. A study of this campaign by Ketter (2016) concluded that using Facebook enabled the country to counter the largely negative focus of coverage by the news media. Using social media targeting 'prosumers' - consumers who create and share social media content quickly and easily - spread the word quickly and influenced a wide range of audiences. Facebook was particularly useful because it is widely available; it allows multi-way communication, with comment by and conversation between users; it provides links to external media, thereby leveraging news and public relations stories; and it is low-cost and fast. This campaign was very successful in that it was inexpensive but achieved high impact. As a consequence of its well-designed and targeted post-crisis strategy, Nepal's tourism bounced back rapidly with a $24 \%$ rise of arrivals in 2016 to 730,000 .

Social media was also an important tool for the countries of West Africa affected by the Ebola disease outbreak of 2013/14. Mizrachi and Fuchs (2016) analysed 200 posts made on TripAdvisor and found that responses fell into three categories:

1. Positive thinking and encouragement, offering advice on protection techniques, estimating risk levels and counselling against believing the sensational media hype, with the overall tone being relaxing, comforting and positive;

2. Knowledge development and preparation, suggesting searching for information about the disease from official sources and focussing on pre-trip preparation, with the tone being moderately positive with some expressing neutral opinions; and 
3. Personal risk assessment, with posts evaluating the risk that the tourist would be willing to take, stressing the need to purchase comprehensive travel insurance, and the financial risk perception, with the tone being mostly negative or cynical.

The ASEAN Tourism Crisis Communications Manual (2015) uses similar insights to provide advice to crisis-hit destinations. It identifies 'triggers' that generate media interest, applying equally to traditional or social media. These can be used to understand and shape both the media and public response to a crisis or disaster and also as a means of enlisting the media post-crisis to report on and support the recovery process. The principal media triggers are:

- The numbers of people: most attention is given to events with large numbers involved.

- The type of people affected: coverage will be greater if children, underprivileged or minority groups are involved.

- The prominence of the people involved: there will be more interest if a celebrity or other personality is affected.

- The nature of the incident: more attention will be given to repeat incidents or those that result from mishandling of previous crisis events, or which cast doubt on the integrity of the government or threaten the sovereignty of the country.

- The event's 'visibility': vivid or graphic images can be quickly shared and give rise to an unbalanced impression of the incident.

- The 'fear appeal': the higher the fear factor, the bigger the crisis.

- The provision of conflicting information from authorities, casting doubt on the credibility of information provided.

The significance of these triggers makes it even more important that the tourism industry should present a coordinated response and work closely with the national-level crisis management team. Having said this, it can be helpful for individual tourism businesses to use existing communications links of their own with the international travel and tourism trade and prospective tourists. This is where benefits will be reaped from good and warm relations built up with the media and with the customer-base in the pre-crisis period (this will be elaborated in Section 2). It will be helpful if the same journalists and bloggers who filed initial reports on the crisis also file subsequent reports to illustrate the progress being made, including identifying possible human interest stories.

The tourism system (i.e. including the destination, generating regions and transit between them, after Leiper's 1979 model) involves the local community as well as organisations from the public and private sector; those directly involved in tourism and those involved indirectly through linkages within the supply chain; and those local to the destination and located further afield, including in different countries. In a crisis situation, all stakeholders should be incorporated in the recovery programme and collaborate within it. In their investigation of stakeholder collaboration within the context of threats to tourism from a cyclone affecting the Australian state of Queensland, Jiang and Ritchie (2017) found that more effective outcomes were achieved when stakeholders were strongly motivated to collaborate, and that motivations for collaboration were related either to the perceived benefits of sharing available resources such as information and funding, or to 
strong pre-existing relationships between stakeholders. This illustrates one of the key elements of tourism business resilience referred to in Section 1.4. above.

\subsubsection{Source Country Travel Advisories}

Finally, the role of source country travel advisories is considered. Governments issue travel advisories to inform their citizens of safety or security issues affecting a particular country or region. They are generally issued across the full range of destination crises, or where a government is no longer able to respond to difficulties experienced by its citizens: for instance, if consular services are undermined by local unrest. There is sometimes a distinction between long- and shortterm advisories, the former covering long-standing situations such as civil wars, with the latter covering temporary issues such as environmental disasters or election-related demonstrations. In either case, the advisory can have a devastating effect on a tourism-dependent destination (UNWTO, 2011). The UNWTO recommends issuing a reassuring - but truthful - statement on the situation, noting awareness of the advisory and stating that all possible measures are being taken to resolve the situation.

Of course, travel advisories are literally 'advice' and cannot prevent people from travelling to a destination. However, travel insurance will generally be invalidated if travel is undertaken in defiance of advisories, which means that these constitute a strong prohibition against travel. More experienced travellers are likely to access the considerable independent advice available on social media, blogs and forums such as TripAdvisor, the Lonely Planet discussion forum ThornTree, or websites such as smartertravel.com.

\subsection{Conclusion}

The clear use of a framework to guide preparations for a crisis will help those concerned with managing it to adhere to an agreed set of actions, while understanding the resilience cycle and how it affects businesses is essential background for the key stakeholders in a tourism system as it will give insights into the actions to be taken to prepare for and recover from crises. The principles and key actions of crisis communications should be integrated into the crisis management framework.

The next section of the report will cover practical strategies and actions to be taken at each stage of the crisis management process. 


\section{MITIGATION STRATEGIES AND ACTIONS}

Due to the frequency of crises and the institutional learning which has taken place through efforts to deal with them, techniques of crisis management have evolved over the last two decades from a reactive, top-down approach to a form which seeks to be proactive in reducing the occurrence of crises, to minimize the negative consequences of those that do occur, and to hasten recovery times through swift and effective actions. This section will follow the structure proposed by Faulkner's 2001 crisis (or disaster) management framework, as discussed in Section 1, in outline actions which should be taken, and it will also consider the role of different stakeholders in crisis management.

It will now be considered how tourism crisis management should be integrated more generally into an overall approach to Disaster Risk Reduction (DRR).

\subsection{Tourism Crisis Management and Disaster Risk Reduction Strategies}

Many countries have a national system for DRR and for dealing with crises or disasters, normally headed by a nominated government department. It is not possible to give a categorical blueprint for the structure and composition of these agencies, groups or committees, since they vary from country to country. Examples include the Department of Homeland Security in the USA, the National Disaster Management Authority in Pakistan, and a division of a government law and justice department in Australia entitled 'Emergency Management Australia'. In Britain an emergency committee of various government officials is constituted as soon as a crisis occurs, with its composition dependent on the nature of the crisis. Germany takes a regional approach, with the 16 states of the federal republic responsible for rescue services, fire-fighting services and crisis control (both natural and technical disasters). In most cases, representatives of key agencies such as police, health, transportation, public works and city administration are likely to be involved.

The Hyogo Framework for Action, developed by the UN Office for Disaster Risk Reduction in 2005, formalised this approach to DRR, acknowledging the role of governments and international agencies and detailing the responsibilities of different sectors and stakeholders in order to build the resilience of nations and communities to disaster and reduce the social, economic and environmental losses caused (UNISDR, $n / d$ ).

The principal steps of national-level DRR entities are to:

1. Set up an institutional framework to be activated in times of crisis

2. Appoint members from different government agencies (with private sector representation, as required) with a designated officer to act as the institution's spokesperson

3. Identify risks which could lead to crisis

4. Plan a set of policies, procedures and strategies to guide the actions to be taken when a crisis occurs. Such procedures and actions need to be clear and comprehensive but flexible enough to respond effectively to the specific needs of different crises. 
Where crises affect tourism, these will generally link tourism-related public and private sector stakeholders with other civil defence and community response groups, enabling tourism to be integrated with the existing system of DRR (Becken and Hughey, 2013). However, as noted in Section 1, all too often the national-level crisis or disaster management unit and the NTO/TB work independently of each other, especially where tourism is not a government priority, even though the biggest casualty of the crisis has in many cases been the tourism sector (Upadhya, 2014). Morakabati et al (2017) also note that there is often a disconnect between the public sector agencies responsible for emergency management and tourism interests, due to the lack of formal communication and recognition of responsibilities, even to the extent of working on opposing agendas during an incident. The underlying reason for this is often that governments will focus on the magnitude of an emergency in order to maximise international support in recovery and reconstruction, while the tourism sector will want to focus on maintaining business continuity by ensuring that operations proceed as normal in unaffected areas of the country and on the restoration of services in the affected area.

The limited integration of tourism within overall DRR strategies was noted by Laws and Prideaux in 2005 and commented on further by Becken and Hughey (2013), who contend that tourism should be integrated within DRR strategies due to:

1. Tourists' particular vulnerability because of their mobility, unfamiliarity with local environments and language barriers;

2. Tourism's extensive use of infrastructure such as airports, roads, water and sewage systems;

3. The erosion of the destination's image and consequent economic losses resulting from disruption;

4. The potential of tourism businesses for providing expertise and equipment to help address an emergency situation.

Because of these factors, the UNWTO also encourages the increased integration of tourism within overall DRR planning. It recommends that countries "develop a national policy on tourism safety commensurate with the prevention of visitor risks" and that they form national tourism councils with executive committees responsible for risk management in key areas, according to the needs of each destination. In the May 2017 progress report to the Executive Council on the UNWTO's 201617 Priorities and Management Vision, the Secretary-General, Taleb Rifai, stressed that: "building resilience within the sector requires a realignment and full integration of tourism systems within the national and local disaster risk and emergency management structure. It further requires this responsibility to be shared amongst all relevant stakeholders at the local, national and international levels."

\subsection{Key Organisations and Roles in Tourism Crisis Management}

Most governments establish specialist departments or agencies to develop, administer and promote their tourism sectors at national, regional and local level. At national level there is normally a National Tourism Administration (NTA), usually a Ministry (or department within a 
ministry such as a Directorate-General), as the central government body with overall responsibility for establishing tourism policy and legislation, and a National Tourism Organisation (NTO) or Tourism Board, which may be a public-private partnership funded largely by the private sector. The Tourism Board may be connected with the Ministry, or it may be an autonomous body established for the promotion of inbound international tourism and (increasingly) domestic tourism. In some instances, this role has grown over time to encompass facilitation and coordination of tourism services and the Tourism Board is effectively a Destination Management Organisation (DMO). It should be noted there is some confusion over the term DMO: in some cases it stands for 'Destination Marketing Organisation', and in others for 'Destination Management Organisation'. In this report 'DMO' is used to refer to 'Destination Management Organisation'.

A DMO generally operates at regional or local level. In the majority of cases they represent the destination value chain, usually involving public and private stakeholders in terms of membership and funding (UNWTO, 2011). According to an analysis carried out by Beaumont and Dredge (2010) destination governance operated by DMOs falls into three categories, all representing some form of network structure: led by the public sector; led by participants, including businesses and the local community; and led by industry. The overarching role of DMOs in destination management makes them key to the management of any crisis, and in some cases they may lead on developing the crisis management plan.

Specific groups of private sector operators are represented in trade representation bodies such as hotel, restaurant, or guide associations. These will liaise with the DMOs, and their representatives should be included in crisis management planning.

The resident population of areas directly or indirectly affected by tourism through their jobs and livelihoods, as well as the environment in which they live, are key stakeholders and should also be included in crisis management and recovery. Their involvement may be through representation on national or local level government or partnership bodies.

\subsubsection{Stakeholder Roles in Crisis Management}

The initial phases of dealing with crisis situations are carried out by the national (or regional) crisis or disaster management unit, while once the early stages of the crisis are over or under control the NTO/TB/DMO will lead on the damage limitation exercise of arresting or reversing the decline in arrivals (Upadhya, 2014).

While the primary concern for individual tourism businesses in areas affected by a crisis is their own enterprise, it is essential for businesses to collaborate with each other and with the NTO/TB/DMO in order to restore the market credibility of the destination and reverse the decline in tourist arrivals. This awareness was confirmed by businesses surveyed for this study, with 'quick dissemination of information and good communications between industry colleagues' spontaneously mentioned in the project team survey in eight case study countries as measures to be taken by the tourism industry.

Despite the growth of direct booking via the internet and the associated rise of independent travel, travel and tourism businesses still act as intermediaries between prospective tourists and 
destinations in the majority of cases. This is because of the convenience of a 'one-stop shop'; the purchasing power of large tour operators, which reduce costs for the consumer; and security, so that in the event of a crisis or business failure of the company concerned the consumer has some financial protection, e.g. British travellers are protected through the Association of British Travel Agents (ABTA) and the Air Travel Organiser's Licence (ATOL).

All travel and tourism operators are responsible for the safety and satisfactory experiences of their clients in the destination. For this reason, international transport organisations and tour operating organisations have established protocols and procedures in the event of emergencies, for instance the 'Emergency Response Handbook' produced by IATA (the International Air Transport Association), and the UK Federation of Tour Operators' code of practice for land transport in the destinations featured by members.

In the event of a crisis occurring in a destination, stakeholders such as outbound tour operators and airlines generally adopt a conservative response and evacuate their customers as rapidly as possible. This is partly because operating to a destination against the official advice of their home government invalidates a company's insurance cover, and partly because they seek to avoid any risk to their customers - primarily because of the risk of damage to their reputation as a safe operator. In most cases international tour operators will offer their clients an alternative holiday in a different destination. In some cases the DMO of the affected destination may be able to demonstrate that there are attractive, secure alternatives elsewhere in the country - especially if financial inducements are provided, as discussed in Section 6. In this case tour operators may consider these options, but will not wish to contravene the travel advisory warnings of their own government.

\subsection{Tourism Crisis Responses: Strategies and Actions}

As discussed in Section 1, destinations hit by events that inhibit their normal tourism operations are faced with a range of tasks with different time frames: the Pre-crisis, Prodromal, Emergency, Intermediate, Recovery and Resolution phases. The need and strategy for rapid and honest communications has been covered above, and in this section the additional key actions which should be taken in each of the six phases are highlighted, illustrated with actions from real-world situations. The examples are chosen to complement the eight case studies detailed in Sections 4 and 5 .

\subsubsection{Pre-crisis}

It is vitally important that policies, procedures and plans of action to prepare for and mitigate the effects of a crisis are made - yet a recent study by Granville et al (2016) found that destinations did not prepare adequately for crises, with implications for response and recovery. An example of different recovery speeds between destinations that preempt (rather than react to) a crisis is a comparison between the public transport bombings in London in 2005 and the nightclub attacks in Bali, Indonesia, in 2002. The recovery effort following the Bali bombings was devised after the attack took place, which led to a slow and laborious revival of tourist confidence and associated revenues. In contrast, security response to the London attacks was quick and decisive, because 
prior to the event the competent authorities had established relationships and practised emergency procedures in the event of a terrorist attack (World Economic Forum, 2015). As a result, the events had no impact on tourism arrivals.

Australia also offers a good example of planning for crises in tourism. Following the terrorist attack of 9/11 in 2001 in the USA, it developed a National Tourism Incident Response Plan, establishing a response framework and actions for national, state, and territory governments to ensure rapid, detailed, and targeted responses to incidents with an impact on the tourism industry (World Economic Forum, 2015).

The project team's research into destination crises around the world indicates that the principal pre-crisis management steps for the tourism sector are to:

1. Set up a tourism crisis recovery task force, ideally linked to and working with the national DRR body.

2. Appoint representatives from NTAs/NTOs and the private sector, with a designated officer to act as the task force's spokesperson, who will work closely with the DRR institution spokesperson to ensure consistency of message.

3. Maintain up-to-date market knowledge in order to maintain understanding of how markets may react at the time of a crisis.

4. Cultivate good relations with the media, so that in the event of a crisis journalists or bloggers who have been identified as being positively predisposed towards the destination can quickly be deployed to disseminate positive messages.

5. Create warm relations with individual tourists, so that in the event of a crisis there is an existing customer-base of people who feel warmly about the destination.

6. Plan policies, procedures and strategies to guide actions if a crisis occurs.

7. Establish capacity building activities to enhance contingency planning to 41 rganiza the risk of personal safety to tourists and employees, as well as property damage.

8. Promote individual and family preparedness among employees.

9. Foster tourism clusters at local level and their integration into their communities' contingency planning.

In the pre-event phase, a range of policies, procedures, multi-representative organization structures and plans need to be established to prepare for and address a range of possible crises. As with the DRR, the composition of a task force will vary from place to place: in Fiji, a Tourism Action Group consisting of representatives from across the travel industry is activated in the case of crisis, for instance after Hurricane Winston in 2016. The grouping had three aims: public relations (to reassure people that most of the infrastructure was intact), marketing (especially tactical campaigns to show prospective visitors that Fiji remained an attractive destination), and finance (to secure funds through arrangements with the travel trade) (TourismFiji, 2016).

The planning process is informed by knowledge and understanding of how tourist markets and the international travel and tourism trade respond to the different types of crisis. Scenario planning is a useful approach in these early stages, i.e. the preparation of contingency plans related to a range 
of scenarios and assessment of the probability of their occurrence in the form of alternative scenarios (Laws and Prideaux, 2005). The scenario-planning approach to the pre-crisis phase of tourism disaster or crisis management includes examining how elements of the tourism system interact with the wider societal and economic context. Understanding these relationships is a precursor to creating more resilient tourism systems.

An example of national level DRR planning incorporating tourism is in New Zealand, where the CDEM (Civil Defence and Emergency Management) Act seeks "coordination across a wide range of agencies, organizations that emergencies are multi-agency events" (MCDEM, 2002). The Act is administered by the Ministry of Civil Defence and Emergency and proposes a "cluster approach" involving individuals, businesses, emergency services and government departments to improve communication and coordination. A bottom-up approach is envisaged through the establishment of local CDEM groups and Regional Plans developed by the 16 regional governments. These jurisdictions align with the boundaries of the Regional Tourism Organisations, which facilitates collaboration, while the 2010 Canterbury earthquake was the catalyst for including tourism organizations as formal partners in the CDEM Group Plans (Becken and Hughey, 2013).

\subsubsection{Prodromal and Emergency Stages (immediate crisis response)}

The crisis may take place too quickly to be able to activate response systems while it is actually happening, especially in the case of a natural disaster such as a tsunami or a terrorist attack perpetrated by an individual. Once the crisis event has occurred, however, fast response is essential. In some cases a competent and speedy response may even prevent an emergency situation organization into a full crisis. The emergency phase covers:

- The safety and welfare of tourists and employees

- Emergency infrastructural repairs

- Handling enquiries from relatives of people affected by the incident

- Media communications to mitigate damage to the destination's image

Ensuring the safety of tourists on the ground in the affected destination is the priority of all elements in the tourism sector. This entails the provision of assistance or intervention during or immediately after a natural disaster to meet medical and basic subsistence needs, and may include evacuating tourists to another country or another region. In some cases, an effective alternative to evacuating tourists is to offer them free transfers to accommodation in parts of the country unaffected by the crisis and an accommodation upgrade. This is particularly appropriate in response to natural disasters where the devastation is often limited to a relatively small geographic area. Enabling visitors to continue to enjoy their experience in the destination serves both to lessen any negative impressions, and to reduce future cancellations by intending visitors, who will see that current visitors are well looked after and that parts of the country are operating normally.

Rapid infrastructural repairs may need to be carried out, in particular the restoration of clean water supplies to prevent the spread of diseases such as cholera, the repair of roads so that emergency 
supplies can be transported to the affected area, and the reestablishment of communications systems.

Relatives of people affected by the crisis will understandably be anxious, and destinations should ensure that enquiries from concerned parties can be quickly handled. Setting up a media communications centre with regular updates on the situation and openness to media enquiries is vital in order to respond to these concerns and also to restrict overly sensationalist and inaccurate reporting. In the case of a crisis or disaster affecting large numbers of tourists, a media communications centre may be hosted by the NTO/TB since this is likely to be in closer communication with the private sector than the NTA/Ministry. On the day after the major earthquake in Nepal in April 2015, the Nepal Tourism Board posted details of emergency phone numbers on its Facebook page, followed up over the next week by several updates, thereby building a reputation for speed and transparency. However, where a transportation incident is concerned, the situation may be handled by the transport company or by a relevant government department such as the Department for Transportation.

In all cases, communications should meet the principles of integrity, honesty and consistency, particularly since any inaccuracies will quickly be uncovered and publicized by affected individuals or investigative reporters. If a private company is responsible for the crisis, it should accept responsibility immediately and not try to blame other forces, and messages should be sympathetic and sensitive towards people caught up in the crisis and their friends and families. For instance, stories could feature individuals reunited with their families or given help by local people. All messages should be channelled through a designated spokesperson, as stated in the crisis communications strategy outlined in Section 1.

For technology-related crises such as transportation accidents, speedy action to investigate the cause of the accident through the adoption of transparent and collaborative actions - particularly in association with agencies of the home countries of affected tourists - can reduce the extent and duration of the negative impacts. After the 2015 Taiwan air crash which killed 43 tourists (mainly from Mainland China), the Taiwan Aviation Safety Council invited accident investigators from China to take part in the accident investigation, and launched a cross-Straits emergency response mechanism. The airline made immediate initial compensation payments to each injured victim and the family of each fatality. This swift response helped to ensure that the Chinese market remained strong over the Lunar New Year holiday period two weeks after the crash (China Daily Asia, 2015). Generally, a combination of several actions will be necessary. Following the 2011 earthquake in Christchurch, New Zealand, marketing communications focused on those areas that were in normal operations while essential repairs were made in the affected area. Tourists planning to visit Christchurch after the earthquake were offered accommodation in locations that were unaffected (Christchurch and Canterbury Tourism, 2012).

\subsubsection{Post Crisis - Intermediate}

Efforts to ensure recovery from crisis should accelerate as soon as the emergency phase of the disruptive event is over, with actions directed at travel trade channels (i.e. tour operators, travel 
agents, conference, organisers), the local tourism industry, and individual travellers. The most common policy responses to crisis are increased marketing, clear improvements to security, strengthened public/private partnerships, and a combination of fiscal and monetary measures.

In the survey undertaken for this study, it was reported that the most effective measures for restoring confidence in the destination and a return to profitable business levels were an increase in marketing activities (including the traditional 'see for yourself' method of familiarization trips), introducing special offers, and targeting new markets. Table 2.1 shows the preferred methods used by businesses and the reasons for their effectiveness. 
Table 2.1: Reasons for effectiveness of measures taken by own Organization

\begin{tabular}{|c|c|c|c|c|c|c|}
\hline Measures & $\begin{array}{l}\text { Increasing } \\
\text { destination } \\
\text { marketing } \\
\text { activities }\end{array}$ & $\begin{array}{l}\text { Organising } \\
\text { fam trips } \\
\text { for tour } \\
\text { operators } \\
\text { and media }\end{array}$ & $\begin{array}{l}\text { Introduction } \\
\text { of special } \\
\text { offers }\end{array}$ & $\begin{array}{l}\text { Targeting } \\
\text { different } \\
\text { markets }\end{array}$ & $\begin{array}{l}\text { Social } \\
\text { media } \\
\text { campaign }\end{array}$ & $\begin{array}{l}\text { Introducing } \\
\text { new holiday } \\
\text { products }\end{array}$ \\
\hline $\begin{array}{l}\text { Reason for } \\
\text { Effectiveness }\end{array}$ & $\%$ & $\%$ & $\%$ & $\%$ & $\%$ & $\%$ \\
\hline $\begin{array}{l}\text { Improved } \\
\text { confidence in the } \\
\text { destination/ } \\
\text { Positive } \\
\text { information }\end{array}$ & $21 \%$ & & & & $25 \%$ & \\
\hline $\begin{array}{l}\text { Increased } \\
\text { awareness of the } \\
\text { whole region/ of } \\
\text { specific areas }\end{array}$ & $11 \%$ & & & & $13 \%$ & \\
\hline $\begin{array}{l}\text { Provided } \\
\text { factual/actual } \\
\text { information }\end{array}$ & & $50 \%$ & & & & \\
\hline $\begin{array}{l}\text { To adapt to } \\
\text { competition }\end{array}$ & & & $14 \%$ & & & \\
\hline $\begin{array}{l}\text { Targeted } \\
\text { markets/market } \\
\text { segments most } \\
\text { likely to visit/ } \\
\text { Least affected by } \\
\text { Crisis }\end{array}$ & & & & $45 \%$ & & \\
\hline $\begin{array}{l}\text { Captured new } \\
\text { markets/segments }\end{array}$ & & & $36 \%$ & $10 \%$ & & $19 \%$ \\
\hline $\begin{array}{l}\text { Can reach large } \\
\text { audiences, } \\
\text { fast/Cost effective }\end{array}$ & & & & & $25 \%$ & \\
\hline $\begin{array}{l}\text { Increased } \\
\text { awareness of our } \\
\text { business }\end{array}$ & & & & & $13 \%$ & \\
\hline $\begin{array}{l}\text { Enables direct } \\
\text { inputs from } \\
\text { visitors }\end{array}$ & & & & & $13 \%$ & \\
\hline $\begin{array}{l}\text { Provided varied } \\
\text { product offer to } \\
\text { customers (new } \\
\text { and repeat) }\end{array}$ & & & & & & $31 \%$ \\
\hline
\end{tabular}

Source: Project team questionnaire survey in eight case study countries 
Until repairs are made to the key infrastructure and facilities used by tourists in the affected area, efforts to promote destination recovery should be limited to areas unaffected by the even or incident. In the worst affected areas full restoration may take some time, so it is important to localise the "out-of-action" areas by emphasizing that facilities in other places are fully functioning. Examples of this approach were seen in Thailand, Sri Lanka, the Maldives and Malaysia after the 2004 Indian Ocean tsunami, and after severe flooding in the UK in 2014 and 2015-16.

In order to persuade the international travel trade to promote a destination through featuring it in their programmes or otherwise supporting it, destinations should undertake a variety of joint promotions and other forms of collaboration with trade producers. Inbound tour operators are driven by the potential to generate income, and they are more likely to feature destinations for which there is strong market demand and for which the costs (e.g. landing fees, accommodation, and other local elements) enable them to be competitive.

When a destination is hit by an event/incident that negatively impacts on market perceptions, winning back trade requires additional efforts by the destination authorities and tourism sector. Some of these have been outlined above, but the principal elements are familiarisation trips and other promotional efforts, government commitment and leadership, and reducing local costs and taxes and providing subsidies. Details of how these are manifested are given below.

\section{Familiarisation Trips and Increased Promotion}

Familiarisation trips should be aimed at key travel trade personnel, as well as selected media and influential personalities from the source markets. They should demonstrate that the recovery process is well under way and that the destination has resumed offering safe experiences that provide high levels of satisfaction. The Nepal Tourism Board's multi-faceted strategy to recover from the 2015 earthquake included Familiarisation trips for tour operators, media personnel, opinion leaders and celebrities (e.g. international actress Susan Sarandon).

Marketing messages during this period should focus on positive stories about the destination, for example rebuilding work by volunteers in places affected by natural disasters, and encouraging tourists to show solidarity with affected communities by returning. Messages should also try to counter-balance overly sensationalist reporting and create a more realistic impression of the scale of the incident.

An example of increased promotion was when Kenya tackled the combined impact of internal political issues and terrorist attacks in Nairobi and on the coast by almost doubling its marketing budget in 2015/16, creating incentive packages for charter-based tour programmes, and easing visa regulations for South African visitors (a significant market). These actions helped to bring about a recovery in 2016 of around 16\% (Aviation, Travel and Conservation News, 2017). 
During the global economic crisis, marketing and promotional efforts directed at European and North American source markets were the most effective instrument for addressing the negative effects of on international tourism (UNWTO \& ILO, 2013). Other aspects of increased activity include travel trade and consumer fairs. These may involve collaboration between the Tourism Board/DMO and private sector of the destination, with support from tour operators based in the source market being targeted.

\section{Government Commitment and Leadership}

Governments can help tourism businesses regain momentum after a slowdown through several means, in particular by swiftly rebuilding the infrastructure and by demonstrating a high-profile commitment to improved security. In the case of terrorist attacks, this includes measures to track down the perpetrators and bring them to justice as quickly as possible, and increased levels of security in tourist areas. The survey carried out for this report cited increased security as the most effective way of responding to terrorist threats and political insecurity, including regional cooperation on security measures. Government-funded promotion in key markets was also thought to be effective. Similarly, a 2017 World Economic Forum report ascribes the main drivers of recovery in Egypt's tourism performance to an increase in government support, including allocating $6.8 \%$ of the total national budget to the sector, as well as strengthening cultural resources to help rebuild the country's image.

Governments must support the industry by demonstrating continued confidence in the area. For instance, after the Bali bombings in 2002, the Indonesian President at the time relocated ministerial meetings from the Indonesian capital Jakarta to Bali and provided financial support for conferences there (Putra and Hitchcock, 2006). Where atrocities have been perpetrated by one ethnic or political grouping against another, the government can try to ensure that retribution or revenge attacks do not take place. In Rwanda, efforts to rebuild a peaceful and stable country and change international perceptions after the genocide of 1994 (in which a fifth of the population was killed) included improving access to education, ensuring that different ethnic groups are fully integrated into the same schools and discouraging children from identifying themselves with a particular tribe, asking them instead to focus on building their common nation (Howard, 2014).

\section{Cost Reduction}

Governments can further support recovery by reducing the costs which have to be passed on to tour operators and tourists, thereby making the destination more competitive. A supportive fiscal policy may reduce or waive visa fees or exit taxes for tourists or allow hoteliers a tax holiday in terms of social security payments or a reduction in the level of bed-taxes, or operators can be given subsidies or low-interest loans, which again help them to cut costs. For example, the Macedonian government offered subsidies to air carriers willing to introduce new destinations within the country. The carriers received $€ 40,000$ for each new destination, and the government also paid them $€ 7$ to $€ 9$ for each ticket purchased on the new flights. As a result, flights by low-cost carriers to Macedonia nearly doubled in 2014 (World Economic Forum, 2015). Partnership arrangements 
between the destination and source market operators may include advertising campaigns or subsidies for brochure costs or website enhancements.

In addition, private enterprises will need to create savings by measures such as creating greater efficiencies such as reducing outgoings. A difficult area to address is how to reduce staff costs, which may need to be done by reducing hours or by laying people off completely.

\subsubsection{Post-crisis Recovery}

The intermediate stages of crisis management will evolve gradually into longer term measures. These fall under the following headings:

1. Infrastructural Development

2. Investment Climate

3. Human Resource Development

4. Image Rebuilding and Repositioning

5. Market and Product Diversification

\section{Infrastructural Development}

In addition to effecting the necessary repairs to infrastructure damaged during the crisis, it is important for destinations to maintain their plans for new and improved infrastructure as this provides the basis for the future expansion of tourism, demonstrates public sector commitment to tourism, and provides confidence to tourist markets, international and local travel trades and prospective investors (both in tourism and other economic sectors).

\section{Investment Climate}

Apart from providing reassurance of the country's return to normal tourism operations by pressing ahead with its own infrastructural development plans, governments of crisis-hit countries can adjust investment conditions by offering various forms of fiscal and other incentives to influence decisions on the scale and timing of future investments. This may be done on a national level to stimulate all businesses, rather than on a sector-specific basis. The Turkish government has engaged in various forms of direct and indirect subsidies to the tourism industry since 2016, including tax holidays on ground rent and payment of employee wages. For instance, in 2009, the US government passed the American Recovery and Reinvestment Act to cut taxes and increase public spending in order to stimulate recovery from the global financial crisis (Zandi, 2013).

The strategy does not always work, however. After an earthquake in 2010 that killed tens of thousands of people and severe tropical storms in 2012, efforts by the Haitian government to reassure the global business World that Haiti was 'open for business' (such as rebuilding the airport and lowering taxes) have not borne fruit, mainly because of the weak context of poor social stability, lack of employability capacity amongst local people, and poor infrastructure 
(The Economist, 2013). Further examples of such policies will be given in Sections 4.2 (Turkey), 4.4 (The Gambia), and 5.4 (Sri Lanka).

\section{Human Resource Development}

Continuing efforts to increase professionalism in tourism and hospitality through capacity-building is essential, particularly to ensure that local people have the skills to access jobs at all levels of the industry. A specific need in terms of preparing for and recovery from crises is to train frontline personnel interfacing with tourists and the media in safety and security procedures. A cadre of managers and other personnel with appropriate linguistic, technical and social skills should be selected from across the sector and trained in the safety and security arrangements in place in the destination, in how these will be enhanced in the event of a crisis, and in ways of communicating these to the public.

In its 'Toolbox for Crisis Communications in Tourism', the UNWTO (2011) stresses the need for personnel in the destination's crisis management team to be fully aware of each member's responsibilities, the team's strategy and procedures, and how to communicate with key audiences. Training of core personnel should be carried out at least once per year, with new personnel in key roles fully trained as soon as possible on appointment.

\section{Image Rebuilding and Repositioning}

During this phase there is a need to address market perception of the destination (or a business in the case of a localised issue affecting it) through image management, and in some cases to reposition the destination in the public mind.

Most prospective tourists draw their knowledge of a destination from a variety of sources, principally word-of-mouth (either from personal contacts or through social media), and travel media advertisements and features. Any news of disruption to tourism in a destination will inevitably create apprehension about its safety and ability to provide enjoyable experiences (in the case of leisure visitors), or to facilitate intended business tasks (for the business traveller). Rebuilding trust in the affected country can encourage a return to higher business levels. Methods can include articles written after familiarisation trips arranged for journalists and bloggers, or webcams positioned in key locations showing in real-time that the area is safe and pleasant to visit. Messages in this category often emphasise the low levels of everyday crime on the streets and the friendliness of local people.

Research was carried out by Walters and Mair (2012) into the effectiveness of marketing messages after bushfires in 2009 in the Gippsland region of Australia destroyed tourism facilities and created anxiety in the public mind about visiting the area. The themes and messages tested on survey respondents are shown in Table 2.2 below: 
Table 2.2: Test Messages Aimed at Revitalising Tourism to Bushfire Affected Area of Australia

\begin{tabular}{|c|c|}
\hline Theme & Message \\
\hline $\begin{array}{l}\text { Open and ready for } \\
\text { business }\end{array}$ & Gippsland, open and ready for business-come, be inspired! \\
\hline $\begin{array}{l}\text { Solidarity/empathy } \\
\text { with local people }\end{array}$ & $\begin{array}{l}\text { Gippsland needs you now more than ever, come and visit, support our } \\
\text { tourism industry and let us inspire you. }\end{array}$ \\
\hline $\begin{array}{l}\text { Community readiness } \\
\text { to welcome visitors }\end{array}$ & $\begin{array}{l}\text { Gippsland, ready to inspire you .... } \\
\text {.... we wouldn't invite you if we weren't ready. }\end{array}$ \\
\hline $\begin{array}{l}\text { Restore confidence } \\
\text { and change } \\
\text { misperceptions }\end{array}$ & $\begin{array}{l}\text { Less than } 5 \% \text { of Gippsland was affected by the Victorian bushfires. In fact, } \\
\text { some of our most inspiring national parks and destinations remain } \\
\text { untouched. All our roads are open and for } 99 \% \text { of our operators it's business } \\
\text { as usual. }\end{array}$ \\
\hline $\begin{array}{l}\text { Curiosity } \\
\text { enhancement }\end{array}$ & $\begin{array}{l}\text { Gippsland's stunning natural attractions are regenerating faster than ever, } \\
\text { visit now and be inspired by the fascinating landscape mosaic of fire recovery } \\
\text { mixed with the usual Gippsland splendor... don't miss this opportunity to } \\
\text { experience the resilience of nature. }\end{array}$ \\
\hline $\begin{array}{l}\text { Short-term discounts/ } \\
\text { price reductions }\end{array}$ & $\begin{array}{l}\text { Visit our website now to take advantage of our special promotional offers and } \\
\text { save up to } 50 \% \text { on accommodation, attractions, and food and wine produce. } \\
\text { Find a variety of inspiring packages starting from just } \$ 200 \text { per couple. }\end{array}$ \\
\hline Visitor testimonials & $\begin{array}{l}\text { "... if you want a peaceful country or coastal break at one of our most } \\
\text { precious destinations, now is the time to go...." }\end{array}$ \\
\hline Festivals and events & $\begin{array}{l}\text { Our events calendar is full of fantastic reasons why you should let yourself be } \\
\text { inspired by Gippsland this February. Whether you're a race goer, a music } \\
\text { lover, or a fan of fiery foods, we have it all going on in Gippsland this summer. }\end{array}$ \\
\hline $\begin{array}{l}\text { Celebrity } \\
\text { endorsement }\end{array}$ & $\begin{array}{l}\text { "I'm a great fan of Gippsland and I was so saddened by the news of the } \\
\text { bushfires in the region. However, having just spent a number of weeks } \\
\text { traveling throughout Gippsland I was surprised to see that many of its } \\
\text { fascinating landscapes remain relatively untouched and it's pretty much } \\
\text { business as usual as far as the tourism industry goes. I strongly urge the } \\
\text { Victorian people to come and see for themselves just how resilient } \\
\text { Gippsland's wondrous natural landscape is...." Denise Drysdale }\end{array}$ \\
\hline
\end{tabular}

Source: Walters and Mair (2012)

It was found that messages endorsed by a celebrity or other high-profile person were the most effective at winning people back, and it was also effective to target people who had visited the area previously. The short-term discounting messages were the least likely to stimulate a visit, while the 'open for business' message was found not to be particularly credible and therefore ineffectual.

Chacko and Marcell (2007) reported on how the city of New Orleans, in the USA, rebuilt its tourism image after Hurricane Katrina in 2006 caused widespread flooding and damage, leading to the public perception that New Orleans was no longer a viable tourism destination. Prior to this it had been popular with both international and domestic tourists because of its cultural heritage, unique gastronomy and its local art, music and festivals; it received around 10 million tourists per year. It was calculated that after the hurricane, the city was foregoing over US\$15 million per day in lost tourism revenues. To counteract negative publicity, the authorities developed a repositioning strategy. They established the New Orleans Media Center to focus media coverage on the undamaged areas of the city and targeted previous visitors, using the campaign slogan "Come fall 
in love with New Orleans all over again". For event organisers - a major segment for the city - the byline used was "New Orleans, just as you remember it".

Similarly, although not in response to a particular crisis, Japan recognised that it needed to reposition itself as far as the Muslim market was concerned in order to attract this growing segment. According to Som et al (2016) it was perceived by Muslim travellers as an unpopular destination due to language barriers, cultural differences, the strength of the Japanese currency, and the distance from primary Muslim markets. Japan responded to these concerns with a more open approach to Muslim tourism through easing visa entry requirements and targeting 1 million Muslim tourists for the 2020 Olympics.

For countries where tourism is operating normally but which are located in areas perceived to be in political turmoil, the task of image-building is a continuous one. Jordan is a case in point. Its marketing aims to reduce the perception of risk and highlights information aimed at increasing tourists' confidence in its ability to perform. It uses webcams, testimonials from onthe-ground tourists, and familiarisation tours for travel writers (Liu et al, 2016). Ongoing messages from a variety of sources, regularly refreshed, are essential to building and maintaining credibility. However, as Carlsen and Hughes (2008) point out, while safety and security are fundamental requirements for the market's positive perception of a destination, projecting safety and security as marketing themes can be damaging for a destination's image should subsequent negative events/incidents occur.

Generally speaking, it is essential for countries to ensure that they retain full awareness of their key markets and how these are reacting both to the crisis and to marketing messages carried out in the recovery period, since this will help them shape appropriate messages (Fall and Massey, 2005). They can do this by surveys, focus groups and scanning relevant travel forums and blogs and the travel trade media.

\section{Market and Product Diversification}

In terms of the resilience cycle discussed in Section 1, the crisis represents the 'release' event which breaks the mould of their tourism model, creating opportunities to develop in new directions according to market trends identified through research. Emerging trends and new travel trade links can be more readily exploited at this stage than when tourism was growing from established markets and segments.

International tourism remains dominated by the advanced economies of Europe, North America and East Asia. However, the past two decades have also seen rapid growth from China, Russia (and, to a lesser extent, other former Soviet-bloc countries), and MENA countries. These markets are becoming increasingly sophisticated and diverse (World Travel Online, 2017; ITE Travel \& Tourism, 2016; Jin and Sparks, 2017) and can represent a useful focus for diversification in periods when traditional markets are deterred by crisis events. Little research has been carried out into more resilient markets, although Ndregjoni and Billa (2010) found that tourists who were highly motivated to travel were less likely to be anxious about risks, while Nugraha (2016) confirmed that 
tourists with prior experience of a destination were less likely to be deterred from visiting it after a crisis. At the same time, there is some evidence that newer markets offer untapped potential and are more willing to travel when offered information about a destination. For instance, Bali turned to the markets of the Middle East, Russia and East Asia after the Bali bombing of 2002 caused Western markets to impose travel advisories on Indonesia (Fallon, 2008; Hitchcock and Putra, 2008).

Another example is Kenya. Faced with a succession of terrorist attacks along the coast and in Nairobi, as well as political developments. Its recovery involved focussing on one market segment for each of its primary product areas, and on market diversification. Targeting the US safari market segment in 2016 saw a recovery in the US market, which overtook the UK as the main generating market. India ranked third because of the strong Indian diaspora in Kenya. Arrivals from other African countries also grew, with Uganda-based expatriates taking advantage of visa-free Interstate passes, and South Africa because of eased visa regulations (as mentioned above). China became the fifth most important market for Kenya, passing traditional European markets of Germany and Italy.

A destination which changed the focus of its marketing in the recovery period is the Maldives, where after the 2004 tsunami the Maldives Tourism Promotion Board allocated US\$ 1.5 million to fund initiatives for joint marketing and promotions in order to stop cancellations. This was successful although the key to recovery was the growth in tourists from emerging generating countries specifically Russia and China - which were the only two markets to show growth in 2005 in the aftermath of the tsunami. Whilst pre-tsunami, Maldives' top five markets were Italy, the UK, Germany, Japan and France, by 2011 China had become the leading market with Russia the fifth most important, these two replacing Japan and France (Carlsen and Hughes, 2007).

In Nepal, less than a month after the 2015 earthquake and in an effort to stimulate the return of tourists, the Nepal Tourism Board targeted consumers likely to be interested in trekking and adventure tourism, on the grounds that this segment would be less risk averse since they engage in sports with an element of risk. The initiative was taken via social media by linking to a travel article entitled 'Adventure travelers leading the way in Nepal's tourism recovery', thus leveraging an article already written by another party (Ketter, 2016).

As part of this approach, new segments that are less susceptible to reports of political unrest or disease outbreaks can be targeted. This includes regional tourists who are likely to have a more realistic view of the severity of the political or health situation in the country than long-haul markets, and more price-sensitive tourists. For instance in Macedonia, after years of unrest, the government boosted subsidies for tour operators focusing on visitors from Bulgaria, Serbia, and Bosnia, while in an effort to recover from recent crises, Egypt decided to grant Indian tourists, historically not major visitors to Egypt, a visa on arrival and to launch a direct flight between Cairo and New Delhi (World Economic Forum, 2015). As a result, it was reported in May 2017 that arrivals from India had risen by 30\% in the first quarter of the year (Egypt Today, 2017). Research on the MICE sector for visits to Thailand found that regional markets were more resilient and less likely to cancel bookings, partly due to the geographical ignorance of long-haul markets (Campiranon and Arcodia, 2007). New tourist segments - frequently in the form of independent 
travellers - can be reached through online bookings and social media, which facilitate interaction with visitors and make it easier for them to learn about and visit the destination.

Countries can develop product development and diversification strategies to remove tourists from areas of political unrest. This strategy has been successful in Egypt, where isolated resorts and enclave cities have been developed along the Red Sea, while in Haiti the isolated peninsular resort of Labadee is fenced, heavily guarded, and completely closed off to locals except for the resort personnel. It is accessible only from cruise ships and guests are not allowed to move outside the resort because of the politically unstable Haitian cities (World Economic Forum, 2015). Avraham and Ketter (2017) report that South Korea decided to target a new market segment and highlight different products in 2010 after a prolonged period of tension with North Korea was deterring traditional markets. It therefore targeted the Malaysian market with medical tourism and shopping, including keeping shopping malls open on a 24-hour basis.

Similarly, it will be seen in the Sri Lanka case study in Section 5.4 that the country diversified its product by opening up new areas for tourism and creating more niche products focusing on natural, wellness and spiritual assets: for instance visits to national parks to view wildlife, hiking and trekking, spa retreats, and a Ramayana trail highlighting links with Asian mythology.

Encouraging domestic tourism in times of economic downturn and during the aftermath of a crisis can also be an important means of filling the void left by international tourists. Although this does not help to generate the important benefit of increasing foreign exchange earnings for the country, it can at least keep tourism businesses operating. The chief benefit of this strategy is that domestic tourists are more likely to be fully aware of the real situation than those outside the country. This approach can also work during times of longer-lasting crisis. For instance, during the global economic crisis of 2008-9, many destinations focussed their marketing and promotional efforts on domestic tourism to encourage people to take 'staycations' in their home country. Countries including China, Brazil and Spain saw domestic tourism to some extent replace the fall in international tourism (UNWTO, 2011). Having said that, domestic tourists in large countries such as India or China are not necessarily any more aware of the realities of a situation than overseas tourists, especially if media reporting exaggerates the extent and impact of the issue (as discussed in Section 1).

\subsection{Crisis Communications}

As with other aspects of crisis planning, the principles of a crisis communication plan must be established in advance of a crisis, in particular the human and financial resources of the crisis communications team. The key to good crisis communications is identifying the risks and possible crises that could occur and developing specific plans for each event. The more detailed the preevent preparation and planning, the more likely it is that the outputs will be effective.

Whatever the crisis, the optimal response is to provide timely information that is accurate, credible and transparent, enabling stakeholders to act on it and prospective visitors to make informed decisions and modify their travel arrangements if necessary. One of the main complaints in the aftermath of a mishandled crisis is the lack of information from the authorities, and a careful 
communications strategy planned in advance can help to avoid this. A clear crisis communications plan can also help to avoid the dangers of sensationalist reporting (Walters et al, 2016), which can all-too-easily turn a minor incident into a public relations catastrophe.

The UNWTO 'Toolbox for Crisis Communications' (2011) outlines a model crisis communications policy, covering the preparation stage, human resources and training needs. Responsibilities are allocated for the development of strategies, positioning and messages, while the hierarchy of authority must be agreed in advance. Key contacts within the lead organisation responsible for the implementation of the crisis communication plan must be known to all members of the team, as well as to other tourism stakeholders. For instance, in Pakistan, the National Disaster Management Authority takes the lead on information management during relations with the media in a crisis situation (Dawn, 2016). In the case of an individual, "this is the go-to person for all internal questions and issues and the one with the authority for making the initial decision to activate the communications plan and its subsequent elements in the heat of a crisis" (UNWT0, 2011, p.14). As time goes on and the crisis evolves through its different stages, managers need to continue monitoring the state of the market and its reaction to the crisis (Fall and Massey, 2005). The key principles of the UNWTO's 'Toolbox for Crisis Communications' are reproduced in Table 2.3. below.

Table 2.3: Principles of Crisis Communications

\begin{tabular}{|c|c|}
\hline Principle & $\begin{array}{l}\text { Actions } \\
\end{array}$ \\
\hline $\begin{array}{l}\text { Appoint crisis } \\
\text { communications team }\end{array}$ & $\begin{array}{l}\text { Designate team members by area of responsibility, and ensure } \\
\text { regular meetings and communications. }\end{array}$ \\
\hline Appoint spokesperson & Nominate spokesperson for all media interaction. \\
\hline Background material & $\begin{array}{l}\text { Provide comprehensive background information and materials on } \\
\text { crisis management team and host organisation online. }\end{array}$ \\
\hline Develop messages & $\begin{array}{l}\text { Draft outline messages in advance of a crisis. Once the crisis } \\
\text { occurs, issue messages through designated spokesperson, focusing } \\
\text { on transparency and accuracy and avoiding speculation. Share } \\
\text { messages with other stakeholders. }\end{array}$ \\
\hline Media access & $\begin{array}{l}\text { Establish crisis channels of communication (e.g. hotline to media } \\
\text { office), schedule frequent updates and access (e.g. press } \\
\text { conferences, releases). }\end{array}$ \\
\hline Victim care & $\begin{array}{l}\text { Establish special communications channel and designate team to } \\
\text { work with affected individuals/families, establish procedures for } \\
\text { providing assistance and chain for rapid approval at highest level. }\end{array}$ \\
\hline $\begin{array}{l}\text { Internal employees } \\
\text { communication }\end{array}$ & $\begin{array}{l}\text { Activate communications system with frequent updates to } \\
\text { employees only (emails via intranet, text messages). }\end{array}$ \\
\hline Website/Facebook & $\begin{array}{l}\text { Activate dedicated crisis website (via pre-designated web-master), } \\
\text { update frequently, including prominent link to regular website. } \\
\text { Post updates on Facebook page. }\end{array}$ \\
\hline $\begin{array}{l}\text { Cross-functional } \\
\text { integration }\end{array}$ & $\begin{array}{l}\text { All organisations in team to be engaged in decision-making; at least } \\
\text { daily interface with crisis communications team. }\end{array}$ \\
\hline Quantity and quality & $\begin{array}{l}\text { Ensure swift and accurate fact-finding channelled to crisis } \\
\text { communications team (through industry representatives on the } \\
\text { ground). }\end{array}$ \\
\hline Monitoring & $\begin{array}{l}\text { Measure media and public exposure hits and perception, survey } \\
\text { post-crisis including at } 3,6 \text { and } 12 \text { month intervals, assess results } \\
\text { and develop recommendations for improvements }\end{array}$ \\
\hline
\end{tabular}




\subsection{Conclusion}

Finally, the UNWTO's crisis guidelines for tourism are adapted, as shown in Tables 2.4-2.6 below. These summarise the points in Sections 1 and 2 by giving clear guidance on the step-by-step approach to be taken to prepare for and recover from a crisis.

Table 2.4: Before Crisis: Preparing for the Worst

\begin{tabular}{|c|c|}
\hline Strategy & Actions \\
\hline \multirow{5}{*}{$\begin{array}{l}\text { Putting a crisis } \\
\text { communications } \\
\text { strategy in place }\end{array}$} & Prepare a crisis management plan \\
\hline & Designate spokespersons \\
\hline & Establish a press and communications department \\
\hline & Communicate regularly with the media to establish good relations \\
\hline & Pay attention to local media \\
\hline \multirow{5}{*}{$\begin{array}{l}\text { Promotion } \\
\text { planning }\end{array}$} & Develop a database of partners in the travel trade \\
\hline & Be honest and ethical in promotion \\
\hline & Set aside budget reserves for emergencies \\
\hline & Stay out of a travel advisory war with source country governments \\
\hline & $\begin{array}{l}\text { Improve communication of safety and security issues with tourists and with source } \\
\text { country governments }\end{array}$ \\
\hline \multirow[t]{4}{*}{$\begin{array}{l}\text { Reviewing } \\
\text { security systems }\end{array}$} & $\begin{array}{l}\text { Maintain close relations with other government departments responsible for } \\
\text { safety and security, especially linking with the national DRR unit }\end{array}$ \\
\hline & Get involved in defining security procedures \\
\hline & Train local personnel in security issues \\
\hline & Establish tourist police and emergency call centres \\
\hline \multirow{4}{*}{$\begin{array}{l}\text { Research } \\
\text { readiness }\end{array}$} & Establish strong contacts with key partners in the private sector \\
\hline & Monitor hospital admissions involving tourists \\
\hline & Monitor crime against tourists \\
\hline & Maintain strong awareness of trends in key and emerging source markets \\
\hline
\end{tabular}

Based on UNWTO (2003) 
Table 2.5: During a Crisis

\begin{tabular}{|c|c|}
\hline Strategy & Actions \\
\hline \multirow{9}{*}{$\begin{array}{l}\text { Communications } \\
\text { from the affected } \\
\text { area }\end{array}$} & Act fast \\
\hline & $\begin{array}{l}\text { Activate a pre-planned media centre and internet based sites, especially a } \\
\text { dedicated web-page and/or Facebook site; both must be frequently updated }\end{array}$ \\
\hline & Be honest and transparent \\
\hline & Do not impose a news blackout \\
\hline & Remember the victims \\
\hline & Avoid speculation and categorical reassurances \\
\hline & Put the crisis in context \\
\hline & Challenge untrue statements and highlight positive aspects \\
\hline & Network with other news sources \\
\hline \multirow[t]{5}{*}{ Promotion } & Communicate directly with the travel trade and public \\
\hline & Change promotional messages to address safety concerns \\
\hline & Press ahead with promotional events and trade shows \\
\hline & Seek increases in promotional budgets \\
\hline & Initiate financial assistance and/or fiscal measures to support tourism companies \\
\hline \multirow[t]{3}{*}{ Security } & Monitor and explain improvements to safety and security \\
\hline & Coordinate with security services for media access \\
\hline & Communicate internally \\
\hline \multirow[t]{2}{*}{ Research } & Monitor satisfaction levels amongst existing and new visitors \\
\hline & Monitor media reports \\
\hline
\end{tabular}

Based on UNWTO (2003)

Table 2.6: Following a Crisis: Rebuilding Tourist Confidence

\begin{tabular}{|c|c|}
\hline Strategy & Actions \\
\hline \multirow{6}{*}{$\begin{array}{l}\text { Image-building } \\
\text { communications }\end{array}$} & Continue to be proactive in communications \\
\hline & Look for positive stories \\
\hline & Increase familiarisation trips for travel trade and journalists \\
\hline & Remember anniversaries \\
\hline & Anticipate legal action \\
\hline & Update news on destination websites and social media \\
\hline \multirow{8}{*}{$\begin{array}{l}\text { Flexibility in } \\
\text { promotion }\end{array}$} & Create new niche products, including special events / festivals \\
\hline & Target experienced and special interest travellers \\
\hline & Create special price offers and special events \\
\hline & Shift promotion to more promising markets \\
\hline & Step up promotion to the domestic and regional markets \\
\hline & Increase familiarisation trips for tour operators \\
\hline & Take travel advisories seriously \\
\hline & Intensify cooperation across the tourism industry and with other sectors \\
\hline \multirow{2}{*}{$\begin{array}{l}\text { Security for the } \\
\text { future }\end{array}$} & Evaluate security procedures \\
\hline & Work with DRR agences to improve quality of services and facilities \\
\hline $\begin{array}{l}\text { Using research } \\
\text { effectively }\end{array}$ & Survey generating markets on perceptions of your destination \\
\hline
\end{tabular}




\section{TOURISM SECTOR CRISES IN THE OIC MEMBER STATES}

This section covers crises and disasters affecting OIC countries. The first part will examine the types of crisis faced by OIC countries and list the principal events which have affected them, followed by examples of the impact on tourism and some actions taken to counter the effects. The section includes a discussion of Islamophobia, which may be affecting the propensity to travel to Islamic countries from some source markets.

The countries of the MENA region in particular have experienced challenges in attracting tourists from traditional source markets because of developments from 2010.

\section{1. $\quad$ Types of Crisis Faced by the OIC Countries}

A typology of the range of crises and disasters which can affect tourism was outlined in Section 1. These were categorised as:

- Environmental Events

- Societal/Political Events

- Health-related Events

- Technological Events

- Economic Events

In addition, two further categories of crisis which can affect individual businesses were included:

- Accidents affecting tourists

- Incidents affecting businesses

For the purposes of this section, the last 2 categories of accidents and incidents are omitted, since these aspects generally affect individual businesses only.

The tourism and hospitality industries of member countries of the OIC are vulnerable to the same types of challenges as other countries. A review of the literature and recent historical events indicates a number of crises in each category affecting OIC countries: these are outlined in Tables 3.1-3.5. The tables are not intended to be exhaustive lists of all crises in these countries. They include OIC member countries which have (or have had) a significant tourism industry, and include only the major events which have caused significant fears for the safety and security of international tourists, damage to the tourism infrastructure, or significant reputational damage affecting visitor arrivals. Crises which have affected global levels of tourism, such as the 2008 global financial crisis, have not been included as this affected the tourism industry almost everywhere.

For the purposes of this report, OIC countries have been divided into three categories:

1. OIC countries with a significant (or nascent) tourism industry but no recent crises (21). These are: Albania, Algeria, Bahrain, Benin, Brunei, Djibouti, Dubai, Gabon, Guinea-Bissau, 
Guyana, Kazakhstan, Kuwait, Kyrgyzstan, Morocco, Mozambique, Oman, Saudi Arabia, Suriname, Tajikistan, Togo, Uzbekistan.

2. Some OIC countries which need to improve their tourism industry (8). They are: Cameroon, Chad, Comoros, Mauritania, Niger, Somalia, Sudan and Yemen.

3. OIC countries which at some stage have had a significant tourism industry but which have encountered significant challenges due to various types of crises namely environmental, health, socio-political, technological and economic (24). They are: Afghanistan, Azerbaijan, Bangladesh, Burkina Faso, Egypt, Gambia, Indonesia, Iran, Iraq, Ivory Coast, Jordan, Lebanon, Malaysia, the Maldives, Mali, Nigeria, Pakistan, Senegal, Sierra Leone, Syria, Tunisia, Turkey, Turkmenistan, and Uganda. These countries and the principal crises affecting them are listed in Tables 3.1-3.5.

Table 3.1: Environmental Crises affecting Tourism in the OIC Countries

\begin{tabular}{|c|c|}
\hline Country & Event \\
\hline Bangladesh & $\begin{array}{l}\text { Floods, cyclones (e.g. Cyclone Sidr, 2007). Especially threatened by sea-level rise due to } \\
\text { climate change. }\end{array}$ \\
\hline Burkina Faso & Recurring droughts leading to desertification and loss of life (early 1970s, early 1980s) \\
\hline Indonesia & Worst-hit country by Indian Ocean Tsunami $(2004)$. Earthquakes $(2005,2006)$. \\
\hline Iran & Earthquakes $(1990,2003)$ kill c. 40,000 people each time. \\
\hline Malaysia & Indian Ocean Tsunami affects west coast (2004), severe floods (2006). \\
\hline Mali & Drought + plague of locusts causes severe food shortages $(2004-5)$ \\
\hline Maldives & $\begin{array}{l}\text { Indian Ocean Tsunami causes deaths and severe infrastructural damage (2004); especially } \\
\text { threatened by sea-level rise due to climate change. }\end{array}$ \\
\hline Pakistan & Devastating earthquake in Kashmir (2005), serious floods (2010). \\
\hline Uganda & Severe floods cause widespread devastation, state of emergency imposed. \\
\hline
\end{tabular}

Sources: BBC News World Country Profiles; UK Foreign Office Travel Advisories; Wikipedia; various academic papers (as per list of references). 
Table 3.2: Societal/Political Crises affecting Tourism in the OIC Countries

\begin{tabular}{|c|c|}
\hline Country & Event \\
\hline Afghanistan & Political/societal developments \\
\hline Azerbaijan & Occupation of Nagorno-Karabakh by Armenia. \\
\hline Bangladesh & Political developments \\
\hline Burkina Faso & Political developments \\
\hline Egypt & Terrorist attacks, developments from 2010 \\
\hline Gambia & Political developments \\
\hline Indonesia & Terrorist attacks \\
\hline Iran & Political developments \\
\hline Iraq & War and Political developments \\
\hline Ivory Coast & Terrorist attacks and Political developments \\
\hline Jordan & Terrorist attacks \\
\hline Lebanon & War, Political developments and Terrorist attacks \\
\hline Libya & War and Political developments \\
\hline Malaysia & Terrorist attacks and Political developments \\
\hline Mali & Terrorist attacks and Political developments \\
\hline Nigeria & Terrorist attacks and Political developments \\
\hline Pakistan & Terrorist attacks and Political developments \\
\hline Senegal & Terrorist attacks and Political developments \\
\hline Sierra Leone & Political developments \\
\hline Syria & War and Political developments \\
\hline Tunisia & Terrorist attacks and Political developments \\
\hline Turkey & Terrorist attacks \\
\hline Uganda & Terrorist attacks and Political developments \\
\hline
\end{tabular}

Sources: BBC News World Country Profiles; UK Foreign Office Travel Advisories; Wikipedia; various academic papers (as per list of references).

Table 3.3: Health-Related Crises affecting Tourism in the OIC Countries

\begin{tabular}{ll} 
Country & Event \\
\hline Gambia & Ebola $(2013-16) ;$ no deaths but affected by proximity. \\
\hline Guinea & Ebola $(2013-16$; at least 2955 deaths from the disease. \\
\hline Ivory Coast & Ebola (2013-16); no deaths but affected by proximity. \\
\hline Malaysia & SARS epidemic $(2003)$, Avian influenza (2003/4), H1N1 flu virus (2009). \\
\hline Senegal & Ebola (2013-16); 1 death but affected by proximity. \\
\hline Sierra Leone & Ebola outbreak (2013-16) causes 14,122 deaths.
\end{tabular}
Sources: BBC News World Country Profiles; UK Foreign Office Travel Advisories; Wikipedia; various academic papers (as per list of references).

Table 3.4: Technological Crises affecting Tourism in the OIC Countries

\begin{tabular}{l|l} 
Country & Event \\
\hline Malaysia & Airlines incidents \\
\hline Egypt & Crash of an Air flight \\
Sources: BBC News & World Country Profiles; UK Foreign Office Travel Advisories; Wikipedia; various academic papers \\
(as per list of references).
\end{tabular}


Table 3.5: Economic Crises affecting Tourism in the OIC Countries

\begin{tabular}{l|l}
\hline Country & Event \\
\hline Bangladesh & Collapse of garment factory building and poor working conditions \\
\hline Indonesia & Monetary crisis linked to Asian economic crisis (1997-98) \\
\hline Iran & Currency (rial) loses 80\% of value due to sanctions (2011-12). \\
\hline Ivory Coast & Economic crisis (1980s) \\
\hline Jordan & Economic strain due Gulf War (1990) \\
\hline Malaysia & Asian financial crisis (1997). \\
\hline Nigeria & Falling oil prices (2016).
\end{tabular}

Sources: BBC News World Country Profiles; UK Foreign Office Travel Advisories; Wikipedia; various academic papers (as per list of references).

It can be seen from the tables above that by far the most significant category of crisis is 'societalpolitical'. The countries listed in that category have experienced insurgencies, civil unrest, civil wars and/or terrorist attacks, sometimes linked to economic crises. In each case, the countries concerned have experienced a decline in tourism because of the events.

\section{The Issue of Islamophobia}

For Muslim countries, an additional challenge to be addressed is the impact of Islamophobia which is a misperception mainly observed in Western countries. Islamophobia also negatively effects Muslim countries' image as tourism destinations.

Exacerbated verbal or physical attacks on Muslims the Islamophobia is particularly marked in Western economies by a parallel growth in the popularity of extremist right-wing political movements. A particular target for such groups is people perceived as 'immigrants', even if these individuals were born in the country concerned.

The numbers are increasing, with more open expression of anti-Islam views and discriminatory actions such as the banning of the burkha, niqab and even the hijab. These actions affect the travelling public and feed into their perceptions of travel to Islamic or predominantly Muslim countries.

Consequently, in Islamic Countries investment in marketing and promotion has to be higher and more sustained than comparable non-Muslim destinations. A key strategy is to feature the rich Muslim heritage and culture in their marketing campaigns.

\subsection{Impact of Crises on OIC Member States' Tourism Sectors}

Although it is challenging to find specific research data pinpointing the effect of the various crises on tourism destinations, a few examples will provide some illustrations.

It is estimated that tourism to Egypt declined by almost $22 \%$ after a series of attacks in 1993, while in Indonesia, in the 6 months after the Bali nightclubs bombings in 2002 arrivals to Bali were only $43 \%$ of the total in the previous 6 months (Pambudi et al, 2009). 
The Avian influenza outbreak in Southeast Asia in 2003-4 resulted in only one death in Malaysia but caused considerable losses to tourism (McLeod et al, 2005). During the 2004 tsunami the Maldives suffered significant infrastructural damage, with 19 out of 87 resorts closed due to damage, but according to Carlsen and Hughes (2008), media coverage exaggerated the extent of the damage. As already discussed, Jordan benefits from a stable government yet is affected by political turmoil in the region: it experienced a 41\% drop in arrivals over the 5-year period 2010-2015 from 8.2 million in 2010 to 4.8 million in 2015 (Liu et al, 2016). As Laws and Prideaux (2005, p.3) note, "a crisis that has a local or regional origin [can] have impacts that reach far beyond the geographic boundaries of the local area or the region". For instance the Gulf War in 1990-91 had adverse effects on the tourism industry of Southeast Asia, as visitors from Europe were concerned about flying long-haul and, in particular, about overflying the Middle East (Hitchcock et al, 1993).

The impacts on tourism of the developments from 2010 in MENA region have been reasonably well researched. Prior to 2010, tourism was the largest employer and contributor to foreign exchange in four MENA countries - Jordan, Tunisia, Morocco and Egypt - and made a significant contribution in other countries in the region, e.g. Syria. In the immediate aftermath of the events of late 2010 / early 2011, the effect on tourism was dramatic. Arrivals to Egypt declined from 13.7 million in 2009-10 to 7.9 million in 2013-14 (Mansfield and Winckler, 2015), and a further 5\% decline was reported in 2014-15 (UNWTO, 2016). Tunisia experienced the most dramatic fall in arrivals, with a decline of $12 \%$ between 2010 and 2014 and a further $25.2 \%$ in 2015 (see also case study in Section 4.3). It has been noted by Mansfield and Winckler (2015) that whereas countries in the MENA region recovered rather quickly from one-off events such as the killing of tourists in Luxor, Egypt, in 1997, the 2010-11 events are taking longer to recover from because of the duration and geographical spread of the crisis.

In Sierra Leone after the Ebola outbreak (2013-16), 80\% of tourism and hospitality employees lost their jobs, with knock-on effects on the multiplier effect as well as for government revenues and businesses along the supply chain (Kongoley, 2015). But although the countries principally affected by the outbreak - Guinea, Liberia and Sierra Leone - accounted for under 1\% of international arrivals to Sub-Saharan African countries, concern about the disease impacted on countries thousands of miles away which had no cases. A poll of 500 inbound tour operators in Africa found that half of them had experienced cancellations due to the virus by the end of 2014 (Travelmole, 2014) and research for this report indicated that the effects continued to be felt for at least two years afterwards (Gambia and South Africa case studies, Section 4). This tendency is sometimes because of poor geographical understanding by key markets, and has sometimes been exacerbated by overly dramatic or inaccurate reporting by the media, as discussed in Section 1 .

\subsection{Response Strategies and Actions: During and Post Crises}

The consequences of crises such as those listed in Section 3.1 include:

- Heightened perception of risk and consequent erosion of customer confidence

- Physical damage to tourism infrastructure (in some cases)

- Decisions by consumers to cancel or postpone their trips 
- Removal by tour operators of holidays in affected countries from their brochures and product listings

- Decisions by airlines to reduce flights to affected destinations

- A decline in overall tourist arrivals and occupancy levels for hotels, tour operators and airlines

- Loss of jobs and a fall in the economic benefits of tourism, including reduced incomes and tax revenues

It was noted in Section 2 that international experience in managing crises falls into distinct phases:

1. Pre-crisis planning to prepare for a crisis and mitigate its impacts

2. Response during the event and in its immediate aftermath

3. Response post crisis - short term

4. Response post crisis - medium to long term

A review of attempts to resolve crises affecting the tourism industry in OIC countries has found that the governments and industry of the countries concerned had put in place strategies and actions which fell into these phases. Specific examples of actions taken by OIC countries are given below.

\subsubsection{Pre-crisis Preparedness Planning}

Preparing a management plan in advance is vital to ensuring preparedness for a crisis, the steps for which are outlined in sections 6.3.1. (for the public sector) and 6.4.1. (for the private sector). Prior to the 2004 tsunami, private enterprises in Penang (Malaysia) had clear crisis management procedures at the level of each hotel, tour business and airline. In some cases, crisis management plans are rolled into overall national disaster and risk management strategies, as advocated in Section 2. For instance, Malaysia put plans in place for coping with major disease epidemics after an outbreak of an earlier disease (Nipah virus) in 1999 (Khan, 2017).

\subsubsection{Response During the Event and in its Immediate Aftermath}

After the floods in 2014 which affected areas of Kashmir, social media apps such as Twitter and Facebook were used to identify and send help to the worst affected places and communities (Reynolds, 2014). Due to the ephemeral nature of social media content, it is extremely difficult to find examples of the messages deployed by crisis-hit countries in the aftermath of an incident. However, a good example of a crisis response came after the fatal crash of EgyptAir flight 804 from Paris to Cairo in May 2016. Immediately after the crash, EgyptAir activated its Crisis Center. It posted information on its Facebook page about the disappearance of the flight less than 2 hours from the moment when communications with the flight-deck were lost, and it subsequently posted updates on its website www.egyptair.com and on social media. Its posts were informative and matter-of-fact and avoided speculation as to the cause of the crash when this was as yet unknown. 


\subsubsection{Response Post-Crisis - Short Term}

Again, by learning from experiences elsewhere, some countries have been able to mitigate the impact of crisis incidents on their tourism industry. Hajibaba et al (2016) report that after the beach shootings in Tunisia in 2015, local hotels and tour operators attempted to reassure the market by accepting cancellations free of charge, offering an upgrade to better accommodation, or offering a holiday elsewhere. Targeting domestic and regional tourists to keep businesses active in the absence of foreign tourists has been a strategy pursued by a number of countries in the post-crisis period. This has been particularly successful in the GCC countries (as opposed to the non-oil Arab states) where domestic incomes are high (Mansfield and Winckler, 2015), while some MENA destinations have turned to fellow Muslim countries to fill the gap left by traditional markets, for instance an intensive week-long promotion of Abu Dhabi and its expanded offerings in the Saudi Arabian market (Avraham, 2015).

Where atrocities have been perpetrated by one political grouping against another, the government can help to restore confidence by working to ensure that revenge attacks do not take place. After the Bali bombings in 2002, politicians and opinion leaders called for restraint and used Bali's network of village councils to adopt cultural and religious strategies such as inter-religious worship to help defuse the tension (Hitchcock and Putra, 2005). Similar techniques have been employed in Britain and other European countries.

A good example of rapid recovery after a crisis is Malaysia, which rebounded extremely quickly after two airline catastrophes in 2014. There was no dip in arrivals at all that year, with an overall growth of $67 \%$ - the $3^{\text {rd }}$ highest in Southeast Asia (UNWTO, 2015). The reasons for the swift recovery were twofold. In the first place, measures such as increased airline security helped to restore tourists' confidence. Secondly, the government and private sector worked together to increase marketing efforts. Double-digit growth was experienced in the Spanish market, where Malaysia raised its profile by sponsoring the Sevilla football club, and regional markets were also targeted by introducing more flights from Indonesia and Vietnam. (Lim, 2017).

\subsubsection{Response Post-Crisis - Longer Term}

As discussed in Section 2, in the longer term countries or destinations may need to re-position themselves through appealing to different markets or developing different products to create a more resilient tourism system after a crisis. For example, Ghaderi et al (2012) report that the state authorities in Penang (Malaysia) tried to foster cultural and heritage tourism in the aftermath of the 2004 tsunami because of damage to some of the island's beaches and coastal tourism infrastructure, while Tunisia began to promote health and spa tourism after the developments from 2010 (Mansfield and Winckler, 2015). To some extent these moves should be carried out in any case, since the market is continually expanding and becoming more sophisticated. Government backing for events such as festivals and high-profile sports tournaments which can showcase the destination as well as attracting large numbers of visitors is also important: for instance the Maldives began hosting a world-qualifying surf event on an annual basis as part of its effort to recover from the 2004 tsunami (Carlsen, 2006). 
In the case of Bali, tourism numbers were back to pre-attack levels after the 2002 nightclub bomings by the end of 2004. This was a relatively long time for such a well-established destination. The main reason was that although there was significant help with marketing from consultants, agencies such as the Pacific Asia Travel Association (PATA), and international hotel chains, government travel advisory warnings remained in place in some key source markets for up to 18 months after the attack. While domestic and regional tourists were largely able to make up the difference in terms of numbers, their length of stay and expenditure per trip was lower than for the traditional markets (Gurtner, 2016).

In times of economic crisis, people may still keep travelling but turn to cheaper options. The spread of low-cost airlines throughout Southeast Asia since the Millennium allowed a travel resurgence in some countries affected by the Asian financial crisis of the late 1990s, such as Malaysia.

A further lesson in recovery can be learned from the 21 OIC countries in the first category given in Section 3.1, i.e. those with a successful tourism industry and where no recent crises have been recorded affecting this. As a general rule, these minimise their Islamic heritage in their principal interface with source markets. It is not clear whether this is a deliberate policy to address the issue of Islamophobia amongst source markets, but the effect is that the aspects emphasised are their scenery and other natural assets, cultural heritage (in some cases stretching back two millennia or more), gastronomy, and traditions of hospitality. A brief content analysis of the official NTO or Tourism Board English-language websites of all 21 of these countries show few images of mosques (other than where spectacular architecture is highlighted) but many images of beaches, mountains and other natural landscapes, modern city-scapes, traditional crafts, music and dance, with substantial mention of opportunities for sporting and adventure activities, visiting museums and ancient historical sites, ecotourism, luxury beach tourism, gastronomy, family fun and shopping. Only Kuwait makes a point of clarifying on its tourism website that female travellers should dress modestly in order to help avoid 'harassment'.

\subsubsection{The Role of the Media}

As explained in Section 1, the media can shape the public's perception of events and conditions at the destination as well as the performance of in-country responses to the crisis.

There is a consensus that accurate news reporting is essential, and that negative coverage has often damaged the image of the destination and hindered recovery. Avraham (2015) points out that after the developments from 2010, several countries (including Egypt and Jordan) arranged familiarization trips of journalists and communicated directly with their markets via blogs and YouTube to help with image restoration. This strategy particularly helps to counter a common theme reported on by crisis-afflicted countries, which is that the media tends to exaggerate the extent and harmful outcomes of crises while neglecting 'good news' stories; it is certainly the case that media coverage can be at least partly responsible for the poor performance of unaffected destinations within a country which is subject to crises. 


\subsection{Conclusion}

This section has outlined the principal crises affecting tourism to some member countries of the OIC, examined the impacts of the crisis on the tourism sector, and has given examples of measures taken by the tourism industry in OIC member countries to address the decline in tourism numbers at different stages as the crisis develops.

It has also shown how some countries have diversified their tourism offer and markets in response to crises. This relates to the resilience cycle in that "although crises are disruptive events with the capacity to jeopardise the functioning and sustainability of the tourism industry, they can yield benefits for those involved. In tourism, as in other fields, crises are a source of commercial opportunities. People do not necessarily cease travelling, but may travel in different ways and fears about visiting a particular place can render alternatives more attractive" (Ghaderi et al, 2012, p. 81). The authors cite the cases of the Bali bombs and a coup in Thailand, which drove more business to Malaysia destinations because the country was perceived as stable and safe. Thus, recovery from the crises often allows for rejuvenation of the industry through evolving into a different form, rather than creating an exact replica of the pre-crisis sector landscape.

The next two sections of this report examine case studies of crisis-hit countries, four OIC member countries and four non-OIC countries. 


\section{CASE STUDIES - OIC Countries}

In this section the case studies carried out for this report into crisis management in tourism in four member countries of the Organisation of Islamic Cooperation will be presented. The four case study countries are Indonesia, Turkey, Tunisia and The Gambia, of which the first three were visited by the project team in order to carry out a field study, while The Gambia was investigated via desk research. In each case, an initial brief overview is given of the history and development of tourism in order to set the context for crisis situations that have arisen. The crises or disasters that have occurred are then outlined along with their impact on tourism, followed by measures taken by the government and industry of the country concerned to recover. Successful actions and strategies are highlighted.

\section{1. $\quad$ Case Study 1 - Indonesia (Field study)}

\subsubsection{History and Development of Tourism in Indonesia}

Tourism in Indonesia started during the colonial era. In the 19th century hotels with recreational and leisure services were established, especially in Jakarta (then Batavia) and Bandung. Other hotels were built in early $20^{\text {th }}$ Century in Surabaya, Medan and other important provincial centres. The earliest visitors arriving for leisure purposes were from the Netherlands, which was the colonial power in Indonesia from the $17^{\text {th }}$ century to 1945 . With the first national tourism bureau established by the colonial authorities, early in the 20th century, Bali became more widely known to international tourists for its impressive cultural heritage, religious ceremonies and architecture, dance performances and arts. Before the Second World War most of the international visitors arrived via cruise ships, although long-distance flights commenced from Amsterdam to Jakarta in 1929.

After World War II and Indonesian independence in 1945, the new government began to revive the tourism sector. In 1952, a national committee on tourism affairs was established and delegated to establish Indonesia as a tourist destination. During the late 1950's and early 1960's the sector slowly developed, partly through modern hotels and beach resorts built under war reparations paid by the Japanese. Most of the visitors at the time were business visitors, although some mass tourism was beginning to occur in Bali. Political and economic instability during the mid-sixties caused tourism to die away almost completely. After the political and social situation stabilised in 1967, a directorate general of tourism was established in 1969, and guidelines for developing tourism were issued (Cochrane, 2003).

The first tourism masterplan for Bali was created in 1971, covering the development of tourism resorts in the south of the island. Part of the aim was to protect the cultural heartlands of Bali from over-exposure to tourism. However, due to market pressure and to dissatisfaction from other regions that they were being excluded from the economic benefits of tourism, by 1998 planning was extended to include 15 other locations in Bali (Suparwoko, 2012). 
By the late 1980s several other destinations across Indonesia had become popular with tourists, including Yogyakarta and other parts of Central Java, Torajaland (in Sulawesi), Lake Toba (in Sumatra) and Lombok (the neighbouring island to Bali). All of these destinations except for Lombok were significant for cultural tourism. The capital city Jakarta also attracted tourists, especially business travellers. Much of the increase in tourism development was due to deregulation of the industry: up until the early 1980s the country had depended for its export revenues on the oil and gas sector, but the steep decline in oil prices in the early 1980s caused a serious budgetary shortfall. This stimulated the government to diversify into other areas of export-oriented economic activity, including tourism (Cochrane, 2003).

Throughout the 1980s and up to 1997 the sector developed steadily, as can be seen from Table 4.1 below. The number of international arrivals grew from 129,000 in 1970 to over 1 million by 1987. In the next decade (1988-1997) international arrivals increased by almost $500 \%$, reaching $5,185,000$ in 1997 , accompanied by foreign exchange earnings of US\$ 6,648 million. However, in 1998-99 the country went through severe economic problems and social unrest related to a wider Asian financial crisis, which slowed tourism development. The sector recovered slowly between 1998-2001.

In 2002, as the sector had almost fully recovered from the economic and social uncertainties of the previous five years, terrorists bombed two nightclubs in Bali, killing over 200 people. This impacted the tourism sector not only in Bali but in Indonesia as a whole. The immediate outcome of the attacks was an 11\% decline in the number of visitors for 2002 and 2003 . The sector only recovered fully from the shock in 2004 when the number of international visitors reached $5,321,000$ visitors. However, although there was recovery in terms of regaining the number of arrivals recorded in 2001, the total income in foreign currency was still in decline, as total foreign exchange earnings in 2004 were US\$ 5,226 million, less than US\$ 982 per visit (compared to US\$ 5,227 million in 2001, which represented US\$1,034 per visit).

The strong reaction from the government after the 2002 attacks in Bali, including the security measures implemented after the attacks in Bali and further attacks in Jakarta, were not enough to prevent the terrorists from attacking Bali again in 2005, although the preparedness and coordination of the various authorities and stakeholders reduced the impact of the second attack. Nevertheless, there was a measurable decline in the number of arrivals in 2005 of around $6 \%$, as shown in Table 4.1 . 
Table 4.1: International Visitor Arrivals and Foreign Exchange Earnings - Indonesia

\begin{tabular}{|c|c|c|}
\hline Year & Arrivals ('000) & Receipts (US\$ billion) \\
\hline 1995 & 4,324 & 5.229 \\
\hline 1996 & 5,034 & 6.184 \\
\hline 1997 & 5,185 & 6.648 \\
\hline 1998 & 4,606 & 4.255 \\
\hline 1999 & 4,728 & 4.352 \\
\hline 2000 & 5,064 & 4.975 \\
\hline 2001 & 5,153 & 5.277 \\
\hline 2002 & 5,033 & 5.797 \\
\hline 2003 & 4,467 & 4.461 \\
\hline 2004 & 5,321 & 5.226 \\
\hline 2005 & 5,002 & 5.094 \\
\hline 2006 & 4,871 & 4.890 \\
\hline 2007 & 5,506 & 5.831 \\
\hline 2008 & 6,234 & 8.150 \\
\hline 2009 & 6,324 & 6.053 \\
\hline 2010 & 7,003 & 7.618 \\
\hline 2011 & 7,650 & 9.038 \\
\hline 2012 & 8,044 & 9.463 \\
\hline 2013 & 8,802 & 10.302 \\
\hline 2014 & 9,435 & 11.567 \\
\hline 2015 & 10,407 & 12.054 \\
\hline
\end{tabular}

Sources: UNWTO Yearbook of Tourism Statistics, Compendium of Tourism Statistics and data files

The significant efforts of central and local governments to fight terrorism and restore the country's image subsequently enabled the tourism sector to recover. By 2007 the number of international arrivals had surpassed the number for 2004, totalling 5,506,000 visitors. Since then there has been in steady growth in international arrivals and foreign exchange earnings Purmomarwanto and Ramachandran, 2015). According to the UNWTO (2016), in 2015 there were 10.4 million international visitors to Indonesia, with foreign exchange earnings of US\$ 12,054 million. The WTTC (2017) indicated that the contribution of travel and tourism to GDP in 2016 was $6.2 \%$, which is amongst the highest in the ASEAN region and higher than the growth achieved by other industrial sectors. Where other key metrics are concerned, the WTTC estimated in 2015 that 6.71 million jobs in the country are sustained by tourism (i.e. $5.6 \%$ of the total workforce). 


\subsubsection{Crises Affecting Indonesian Tourism}

The Indonesian Ministry of Tourism classifies crises and disasters into three categories:

1. Natural (e.g. Tsunami; Earthquakes Volcanic Eruptions)

2. Non-Natural (e.g. SARS, Avian Flu)

3. Social (e.g. Terrorism; Political)

According to informants from the Ministry of Tourism, crisis management is a priority for the government, with concern about the impact of crises on tourism at three levels - destinations; services to visitors; and the image of the country (Surana, 2017, pers. comm., 2 May). In addition to external events such as the global economic crisis, tourism in Indonesia has been adversely affected by a range of natural, health-related, and terrorism-related crises in the last two decades, as shown below:

- 1997-98 - Fall of Suharto regime: In the late 1990s the economic recession in Southeast Asia gave rise to a monetary crisis in Indonesia, leading to the overthrow of the regime headed by President Suharto, who had been in power since 1967. The Indonesian currency suffered a drastic decline within a few months and there were significant levels of political and social turmoil. As a result, the tourism industry failed to grow - even though in the decade prior to this there had been significant and rapid expansion (Cochrane, 2003).

- 2000 - Poso Riots: During a sectarian conflict in Central Sulawesi (eastern Indonesia), militants attacked schools and murdered village residents. Three convicted murderers were executed for these crimes in 2006.

- 2000 - Jakarta Stock Exchange Bombing: In September 2000 a car bomb exploded in the Jakarta Stock Exchange carpark, killing at least 15 people and injuring dozens more.

- 2002 - Bali Bombings (No 1): In October 2002, two nightclubs in Bali were attacked by terrorists, killing more than 200 people and injuring hundreds more, with major damage to property (BBC News, 2012). The tourism sector was just recovering from the previous three years of economic, political and social instability, but this attack slowed the recovery and damaged the image of Indonesia as a tourism destination. The decline in international visitors in the next two years was estimated at $11 \%$. The foreign offices for many source markets imposed travel advisory warnings for Indonesia.

- 2003 - flash flood in Bukit Lawang, Sumatra: In November 2003 a river flooded at an inland tourism resort in North Sumatra and swept away guest-houses and other tourism installations, resulting in the death of 239 people (including 5 tourists).

- 2003 - JW Marriott Bombing (No 1): In August 2003 a car bomb exploded outside the Marriott Hotel in Jakarta, killing 14 people, with others injured. This action added to the shock of Bali night club attacks less than a year previously.

- 2004 - Australian Embassy Bombing: In September 2004 a car bomb exploded outside the Australian Embassy in Jakarta, killing nine people and injuring dozens more. 
- 2004 - Tsunami: On December $26^{\text {th }} 2004$, an earthquake in the Indian ocean caused a huge tsunami that devastated several coastal areas in Indonesia, Sri Lanka, Thailand and other countries bordering the Indian Ocean, killing more than 300,000 people, including around 170,000 in Indonesia (although unlike in other countries, tourist destinations were not affected).

- 2005 - Bali Bombings (No 2): In October 2005, three suicide bombers attacked a beach resort in Bali, killing 23 people and injuring more (Bonner and Perlez, 2005).

- 2006 - Avian Flu/H5N1: An outbreak of Avian Flu in Indonesia (Nidom et al, 2010) may have added to the decline of tourism arrivals resulting from other factors in 2005/6.

- 2006 - Yogyakarta Earthquake Java/South Sea Tsunami: Also known as the Bantul earthquake, this took place on $27^{\text {th }}$ May, causing 5,700 deaths and injuring tens of thousands of people. The financial loss was estimated to be over US\$ 3.1 billion, with extensive damage to private houses and businesses (EERI, 2016).

- 2009 - JW Mariott Bombing (No 2); Ritz Carlton Bombing: Two suicide bombing attacks on international hotels in Jakarta killed 9 people and injured many more. The bombings added to the perception of Indonesia being vulnerable to terrorism attacks but did not have a measurable impact on the number of arrivals, either in 2009 or 2010.

- 2009 - Tasikmalaya / Padang Earthquakes: In September 2009, a powerful earthquake struck West Java, killing 44 people and injuring more than 300, and a month later a stronger earthquake struck West Sumatra, with the loss of over 1000 lives. There was no direct effect on the tourism sector, but extensive coverage of the West Sumatran earthquake in particular may have reminded people of Indonesia's geological instability.

- 2010 - Mount Merapi Volcanic Eruption: The volcano Merapi in Central Java erupted in October/November, causing over 350,000 people to be evacuated, while more than 350 people were killed during the eruption, mostly because they refused to leave their homes. The eruption caused aviation disruption across Java (NASA, 2010).

The impact of the various crises is illustrated by the growth (or decline) in international and domestic tourism over the period 2000-2010, as shown in Table 4.1 and Figure 4.1. In the figure, the green bars represent domestic tourism, while the blue bars represent international tourism. 
Figure 4.1: Growth (decline) in International \& Domestic Tourism to Indonesia 2000-10

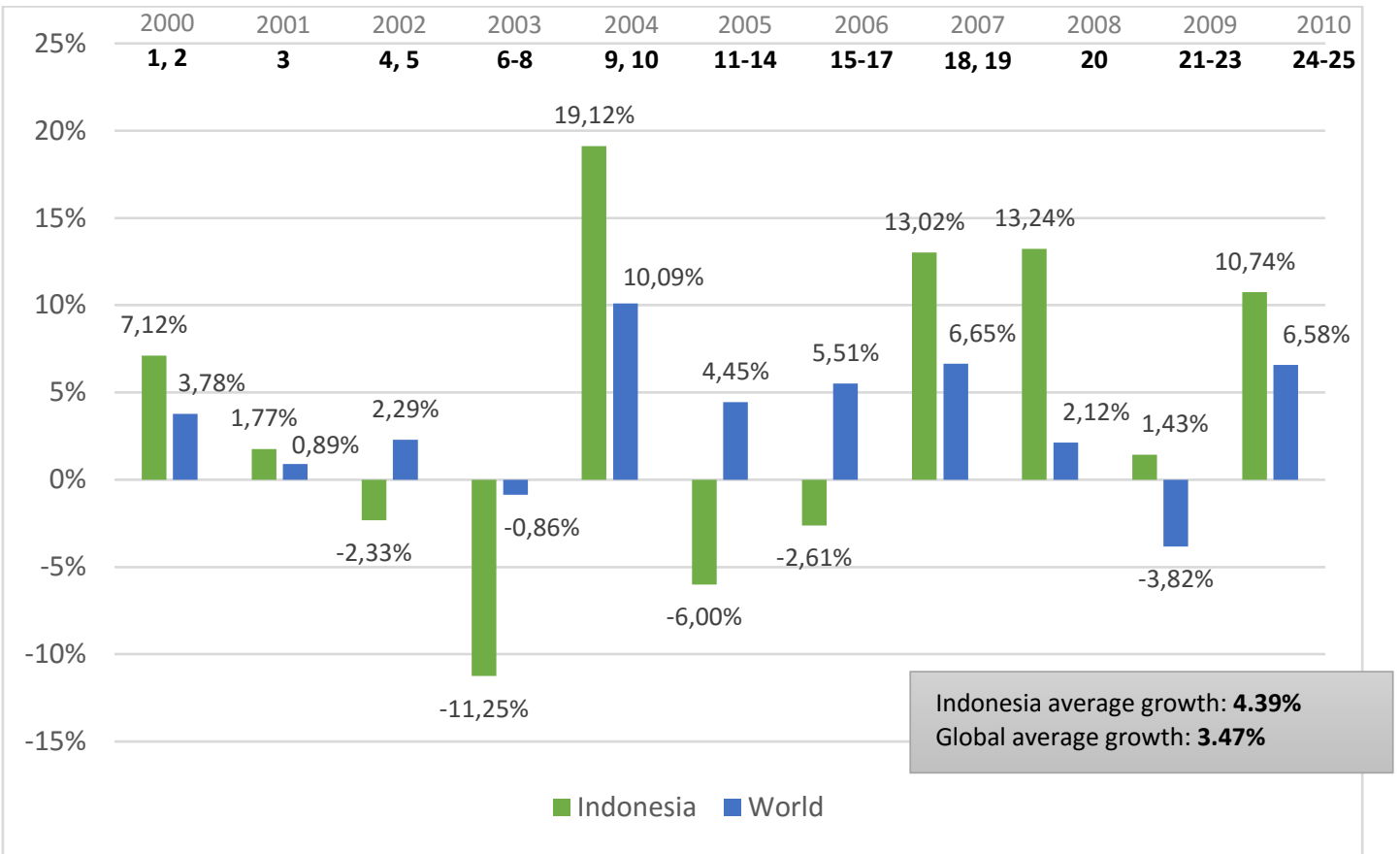

\section{Issues affecting tourism (indicated by numbers in bold):}

1 Inter-ethnic riots, Poso, Central Sulawesi 14

$2 \quad$ Jakarta Stock Exchange Bombing

3 WTC Tragedy $(9 / 11)$

$4 \quad$ Travel Advisory by Australia

$5 \quad$ Bali Bombing 1

6 Iraq Conflict

$7 \quad$ SARS in Asia-Pacific Region

8 JW Marriott Bombing, Jakarta

9 Australian Embassy Bombing, Jakarta

10 Indian Ocean Tsunami

11 Avian Flu

12 Terrorism

13 Increase in oil price
Bali Bombing 2

Central Java earthquake and Tsunami

US Avian Flu

Thai Coup d'Etat

Air Travel Warning by Australia

EU ban on Indonesian airlines

Global Economic Crisis

H1N1 Outbreak

JW Marriott \& Ritz Carlton Bombings, Jakarta

West Java and West Sumatra earthquakes

Thail Political Crisis

Mount Merapi eruption, Central Java

Source: Ministry of Tourism, Indonesia

Of the various crises impacting on Indonesian tourism, the Bali bombings in 2002 and 2005 had the most significant impact, resulting in declines in international visitor arrivals of $11 \%$ and $6 \%$ respectively. These setbacks notwithstanding, Indonesia's tourism sector demonstrated great resilience and recorded average growth of 4.4\% per year over the decade (2000-2010). 


\subsubsection{Recovery from Crises in Indonesian Tourism}

The Indonesian government set up a Crisis Management Team after the first Bali bombing in 2002. This was an ad hoc team led by the Ministry of Tourism's Public Communications Unit, which coordinated closely with other Ministries including Health, Social Affairs, Home Affairs (i.e. internal affairs), and Foreign Affairs. Indonesia also has a separate Disaster Board which collects information on a daily basis and reports directly to the President, but as far as tourism is concerned, responsibility for monitoring crises and disasters lies with the Ministry of Tourism's Crisis Management Team (Kausar, 2017, pers. comm., 2 May). Despite the fact that there was no crisis management plan in place to recover from terrorist incidents (although planning had taken place to recover in the event of floods), the steps taken to recover from the Bali bombing were deemed successful (Andari, 2008), and are shown in Figure 4.2 below.

Figure 4.2: Crisis Management after 2002 Bombings in Bali

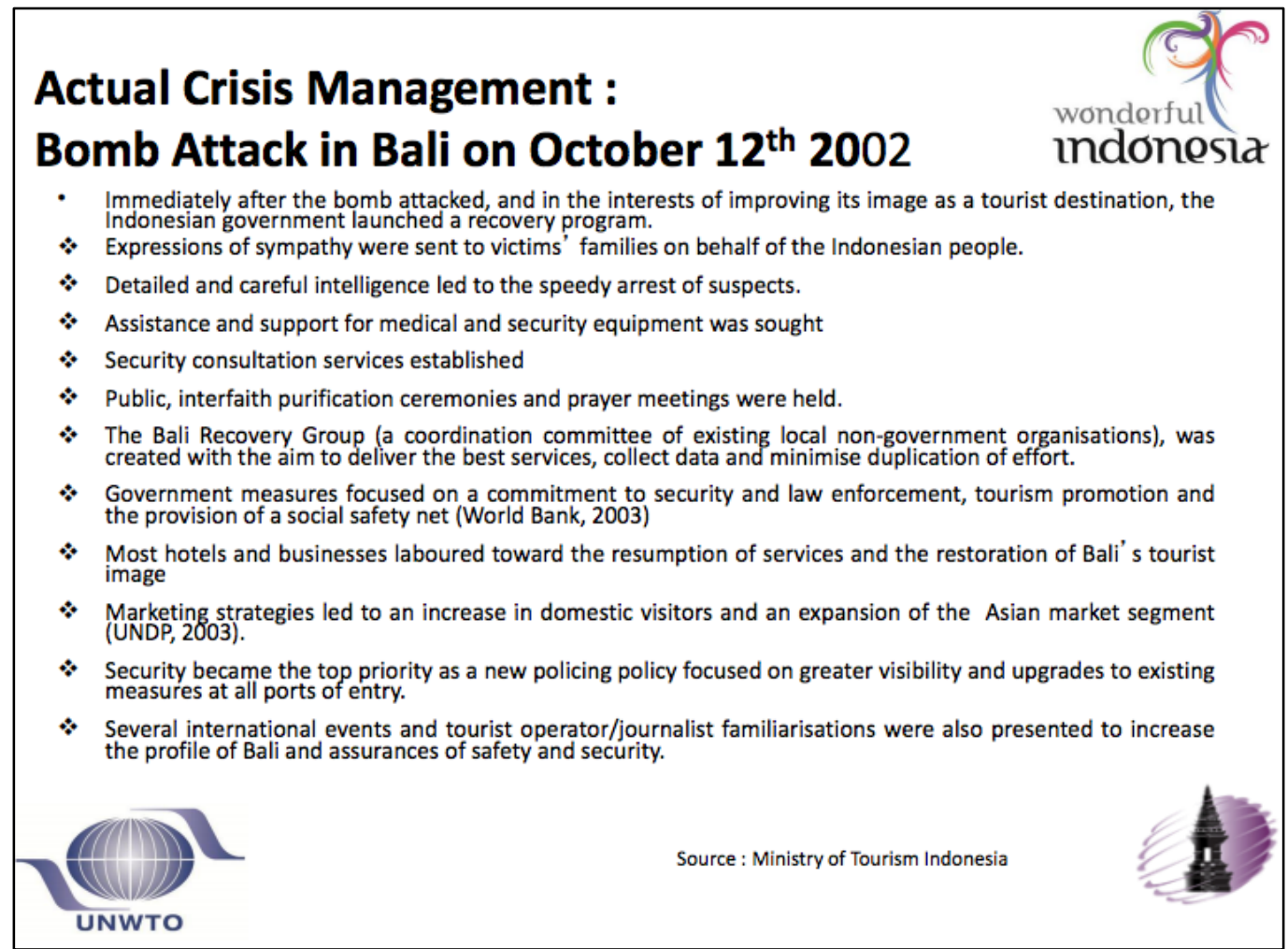

Source: Presentation by Dr. Frans Teguh, Ministry of Tourism (n/d)

After its actions to track down the perpetrators of the 2002 bombings and improve security, the Indonesian government called on the governments of source market countries to lift travel bans and advisories; this was achieved around 18 months after the attacks. In recognition of the advances made by the Indonesian security forces in tackling terrorism, when another tourist facility in Bali was bombed in October 2005, the governments and travelling public of source markets reacted less dramatically than in the previous incident, with the Japanese and Malaysian Governments not strengthening their travel advisories at all (UNECOSOC, 2005). 
After being caught out by lack of planning for the first Bali bomb crisis, the government's response to crisis recovery quickly evolved, with several major initiatives including a 'Nine Steps to Tourism Crisis Recovery' programme put in place by the then Minister of Tourism and Culture, Jero Wacik, in the aftermath of the 2009 bombing of the JW Marriott and Ritz Carlton hotels in Jakarta (Jakarta Post, 2009). Drawing on experience in handling previous crises (most notably the Bali bombing in 2002), the initiative set out a suite of 9 actions to be implemented post crisis. It will be noted that the actions mirror those covered in previous sections of this report. The actions are shown in Figure 4.3 below.

\section{Figure 4.3: Indonesia's 'Nine Steps to Tourism Crisis Recovery'}

1. Establish a Media Centre: Initiative to include appointment of professional PR consultants with international media and tourism industry contacts; regular communication with media to present accurate and up-to-date information.

2. Check Tourist Movements following incident

3. Take Emphatic Action: Identification and inspection of incident site. Establish extent of damage and loss.

4. Localise the problem

5. Communications with Stakeholders: Importance of good communications with all tourism stakeholders in Indonesia and in international source markets.

6. Familiarisation trips: 'Seeing is believing'. Organise familiarisation trips to key tourist locations in Indonesia for media, tour operators, and celebrities.

7. Road show: Undertake road show to include presentations to tour operators and tourists in international markets.

8. Image Restoration Campaign: Secure additional budget for image restoration media campaign in key markets.

9. Event Organisation: Organisation of programme of events at national and regional level.

The current Crisis Management Scheme for Tourism involves a sequence of 3 steps: Information monitoring; Crisis decision; Follow-up decision (as shown in Figure 4.4 below). Following an analysis of primary and secondary data in the first step, the Crisis Management Team determines whether or not a crisis exists. If it is decided that it does exist, the team implements action under the following headings:

1. Action 1 - PR: The goal is to provide accurate information and reassure visitors and localise the issue. This activity is undertaken by the media/PR section of the Ministry of Tourism.

2. Action 2 - Impact Analysis: Each year, the Ministry sets-out a target for international visitors. The impact of the crisis on visitor numbers is monitored closely. Other metrics are also monitored including length of stay, visitor expenditure and hotel occupancy levels. On completion of the impact analysis, the Crisis Management Team advises on appropriate interventions.

3. Action 3 - Crisis Centre: Establish a Media Centre at the crisis location. 
Figure 4.4: Crisis Management Scheme for Tourism

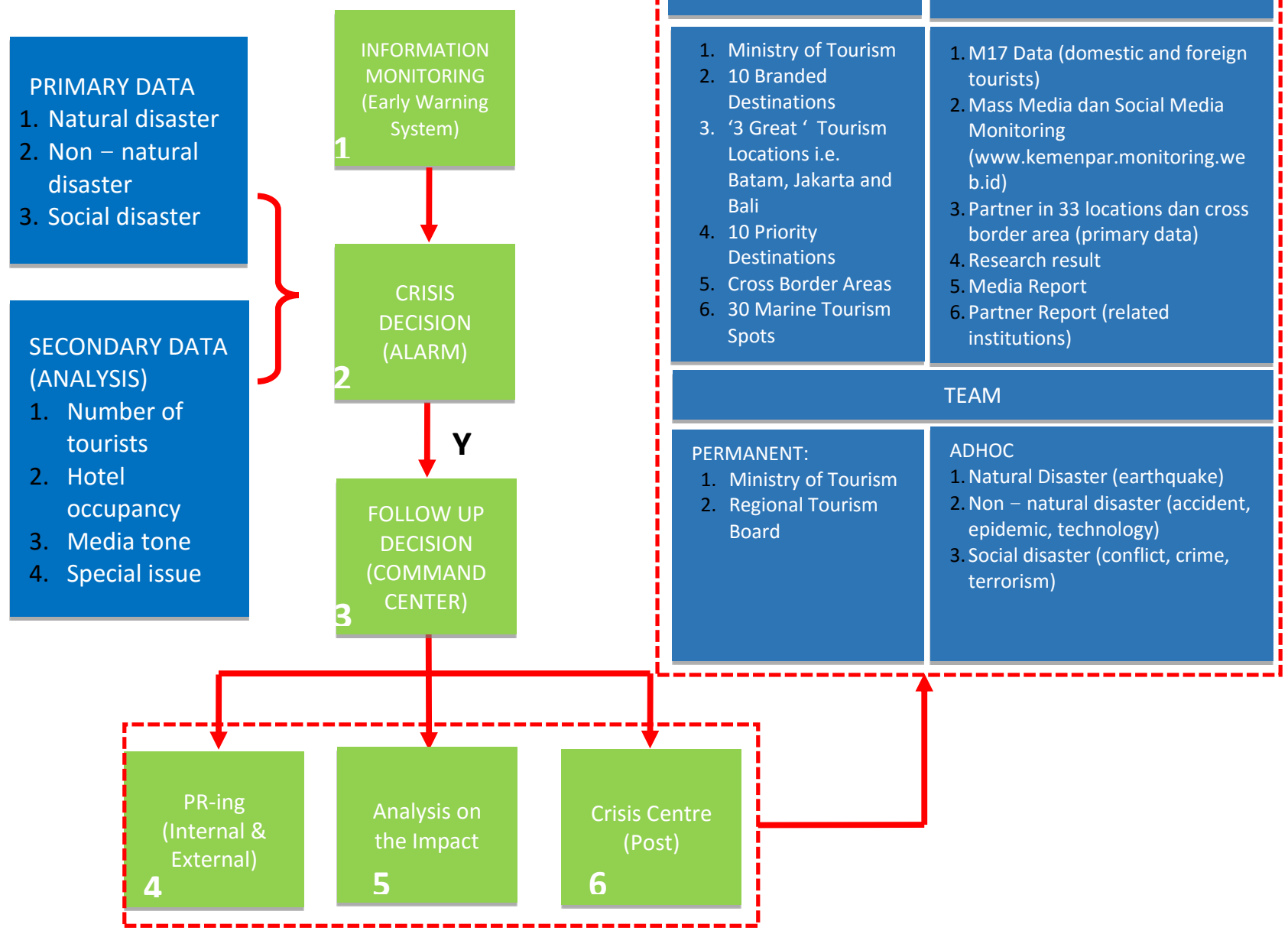

Source: Ministry of Tourism, Indonesia

In times of major crises impacting on the country, the President takes a lead role in press conferences, thus demonstrating high-level commitment to recovery. The Ministry now embraces the use of social media as an effective crisis management communications tool: for instance, a Crisis Centre WhatsApp Group enhances communications and coordination between the centre and Indonesia's regions (Rochmulyati, 2017, pers. comm., 2 May). 
Given the wide range of natural crises it has undergone, the Indonesian experience also provides an insight into recovery from crises, building resilience, and creating tourism opportunities from natural disasters. Thus, three volcanic environments were examined in order to identify ways in which the visitor experience could be enhanced and safety ensured at volcanic locations (Agustan et al, 2016). However, the study found no evidence of risk and crisis management policies at the locations; in fact, in certain cases, managers of key tourist facilities were reluctant to close sites. The study team also found a lack of co-operation between the relevant agencies in the management of tourism attractions in volcanic environments. The team recommended the adoption of Faulkner's (2001) Tourism Disaster Management Framework model in these places (as outlined in Section 1), and proposed the construction of a visitor/interpretative centre to raise awareness of volcanoes and potential hazards, while enhancing the visitor experience through high quality interpretation and supporting facilities.

The niche market of 'Disaster Tourism' or 'Dark Tourism' occurs in Indonesia, i.e. when tourists visit locations which have been affected by disasters to better understand the impact of such events on local communities. Although this niche market is considered by some to be unsavoury because it profits from people's misfortunes, Sarojini Iman examined its impact on communities in Aceh Province following the tsunami in 2004 and found that tourism can play a role in assisting the recovery process and improving the socio-economic circumstances of communities (Iman, 2017, pers. comm., 3 May).

\subsubsection{Critical Success Factors in Resilience of Indonesian Tourism}

- The government planned a marketing campaign in 2008 with a brand 'Visit Indonesia Year'. The campaign included over one hundred events, with a tourism development budget of US\$ 15.9 million was acquired, most of which (80\%) was allocated for promoting Indonesia as a safe destination. The campaign included messages on international media and media visits to attractions and contributed to the recovery of the tourism sector (Simpson, 2007).

- The government eased entry procedures for visitors by adding 45 countries to the visa-free list in 2015. In 2016, through Presidential Regulation no.21, the number of visa-free countries was raised again to 169 countries. Meanwhile the government eased regulations on the disembarkation of passengers from yachts and cruise ships in five Indonesian ports.

- In 2016, the Indonesian government announced that the tourism sector is a central part of the country's economic growth strategy. It is aimed that tourism's contribution to GDP will reach $8 \%$ by 2019 . Accordingly, the budget for tourism marketing was increased from US\$ 30 million in 2014 to US\$ 263 million in 2016 (Putra, 2017, pers. comm., 2 May).

- One of the advantages that Bali had during the social and political instability in Indonesia in 1997-1999 was its exclusion from any riots or social instability, which gave it the reputation as being one of the safest places in Indonesia at the time. The island enjoyed record tourism arrivals during that period, which has benefitted its economy. In 1971 tourism sector contributed 33.36\% to the Gross Regional Domestic Product (GRDP), but by 2000 its contribution to Bali's GRDP had risen to 69.1\% (Suparwoko, 2012).

- Bali still has not only the highest number of tourist arrivals, but also the highest number of foreign visitors in proportion to its inhabitants. In 2000-01 Bali had a total of 736.92 
visitors per 1000 inhabitants, while equivalent figures elsewhere in Indonesia were Central Java received 1.78/1000 in Central Java, 4.83/1000 in West Java, and 81.34/1000 in Jakarta (De Haan, 2016).

- Statistics for Bali over the past 15 years have demonstrated its resilience and the recovery of its tourism industry from crisis, including the growth in domestic tourism. In 2014 foreign arrivals to Bali exceeded 3.73 million, compared to 1.38 million in 2001. Similarly, domestic tourism has grown dramatically, rising from 1.69 million visitors in 2001 to 6.39 million in 2014.

- According to official from the Ministry of Tourism, setting up the Crisis Management Team, with coordination between relevant authorities such as ministries of Health, Social Affairs, Home Affairs, and Foreign Affairs, was an effective step to manage the crisis, take steps to recover from it and restore the tourism industry (Surana, 2017, pers. comm., 2 May).

- The country jumped from rank 70 th in 2013 to rank 50 th in 2015 in international tourism industry (Tourism Industry Indonesia, 2016) due to the rapidly growing number of foreign visitor arrivals, national prioritization of the tourism industry and investment in infrastructure such as communication and air transport. Indonesia was also competitive in prices and in its rich natural resources and presence of several World Heritage Sites.

- In 2004 foreign arrival numbers showed a recovery from the 2002 crisis, and investments and development in the sector resumed. Meanwhile, safety and security measures with appropriate training and awareness education for industry members were implemented. Coordination between various government officials and local authorities were improved. The second wave of attacks in Bali (in 2005) proved that the preparedness of the authorities and their enhanced security procedures were much more efficient than three years earlier and as a result the casualties and reputational damage from the second attack were much less extensive.

- After the Bali attacks and the implementation of security measures, representatives from the police, tourism and hospitality, media, medical personnel, and the host communities got involved in terrorism-focused security audits, crisis training and safety. Meanwhile, international travel advisories regarding terrorism threats are regularly revised, with any change in the advice given representing an indicator of awareness and preparedness of the authorities to face any risk of future crisis.

- Tourism currently is directing collaborative efforts towards the development and expansion of tourism markets and revenues. After the Bali attacks specific strategies were implemented including promotion, market diversification, into new regional areas and niche markets, greater promotion of domestic market, increased package deals, effective management of technology and social media platforms and quality service and products (Gurtner, 2016). For instance, Bali now markets itself as a hub port for yachts and cruise ships, while health and wellness tourism has also been developed. Small-scale efforts to develop and market agritourism, ecotourism and safaris are being made.

- The Bali Tourism Board was recognised for its efforts for the development of tourism and restoration of Bali's image, with the award of: 'World's Leading Island Destination' in 2014, by the World Travel Awards. Such recognition from an international organisation also helps to promote the island as a safe and attractive destination to visit. 


\subsubsection{Weaknesses and Threats to Indonesian Tourism}

- Tourism overdevelopment in some areas, with large resorts and tourism facilities, has led to excessive water consumption, pollution from waste water and ill-treatment and loss of agricultural land. Beach areas and marine fauna and flora may be impacted as well. In Bali some of the environmental concerns include deterioration of reefs in the island, resulting from a high number of visitors and higher water temperatures (although this latter point is related to climate change generally rather than to tourism pressure) (Simpson, 2007).

- Reports of forest fires, illegal logging and encroachment on forested land for plantations of oil-palms, cocoa, coffee, rubber and other cash crops which lead to endangering flora and fauna send negative signals overseas about the sustainability of environmental management in Indonesia.

- In recent years, terrorist attacks against tourists have declined, possibly due to the intensive security measures that the government is taking in fighting terrorism. However with time and with the large number of tourists at some attractions, and with the modern networking and organisation that the extremists are using, there is a fear that future attacks may happen in some of popular destinations with many Western visitors (De Haan, 2016).

- To meet the future expansion of the tourism sector, and in order to diversify the products, new destinations have to be developed. Investing in infrastructure in any new destination is a pre-requisite to attract investors. With most tourists staying in Bali, Jakarta and the Batam Islands (off the eastern coast of Sumatra), it is evident that more investments in infrastructure are needed in order to expand into new destinations.

\subsubsection{Conclusion}

The Indonesian tourism industry went through a period of rapid growth in the 1980s-90s but from the late 1990s onwards experienced a number of shocks and stresses. The first terrorist attacks targeting tourists and other Westerners demonstrated that there was insufficient preparedness amongst the local authorities and stakeholders to manage the crisis, including poor coordination and lack of planning. As the casualties of the attacks represented many nationalities, the impact on the tourism sector and on the image of the country was direct and abrupt (Gurtner, 2016).

In order to restore the sector, successive Indonesian governments have implemented intensive campaigns to restore the image of the country, including setting up a Crisis Management Team tasked with diversifying products as well as source markets. These policies have result in steady growth in tourism to Indonesia over the last decade, reaching 10,407 million visitors in 2015 with foreign exchange earnings of US\$12,054 and employing $8.4 \%$ of the total workforce.

Although tourism in Indonesia is vulnerable to different types of crises, especially natural disasters, societal-political, and health-related, measures taken by the government to stabilise contextual factors and work with a range of stakeholders, as well as diversifying markets, has ensured that the industry is now more resilient. 


\subsection{Case Study 2 - Turkey (Field study)}

\subsubsection{History and Development of Tourism in Turkey}

Istanbul has long been a popular tourist destination for its rich history, its natural beauty and its location linking Europe with Asia. The popular overland train linking Paris to Istanbul, which ran from 1883 to 1977, was known as the Orient Express. Attempts to establish an organised tourism sector in Turkey started in 1923 when the 'Travellers Association' was established, which seven years later became the 'Turkey Touring and Automobile Club'. This played a major role in promoting attractions through its publications of road maps and brochures, and it implemented awareness and educational programmes to develop tourism in its early years.

By 1934 the government started to pay attention to the sector by having an administrative department for tourism as part of Ministry of Economy, which enabled the birth of the National Tourism Administration in Turkey (NTAT). In 1949, the NTAT was restructured to become the Directorate General of Press, Publication and Tourism. The government's interest in tourism as a source of foreign currency and jobs was expressed by the Tourism Encouragement Law in 1953, followed by a five-year development plan. Further efforts were devoted to regulating tourism businesses, licensing and encouraging development of the sector by the establishment of a Tourism Bank. In 1957 the Directorate General was upgraded to a Ministry and represented in the Cabinet. In 1963 tourism was placed as a secondary priority in the development plan under the heading of the service section, although the stated objectives of tourism were to contribute to the national economy through its earnings, encourage domestic holidaymakers, provide jobs and ensure sustainability of natural and cultural tourism products.

The sector has implemented several five-year plans which led to the development of mass tourism, with several beach resorts. During the first plan (1963-1967) the public sector established the basic infrastructure, stimulating the beginning of private sector investment in hotels and other leisure facilities. By the end of the second plan in 1972, the tourism sector had started to show significant growth, and over the four year period 1970-1973, international arrivals almost doubled from 724,000 to 1,341,000. At about the same time the Association of Turkish Travel Agencies (TURSAB) was launched. This non-profit organisation helped to organise travel agents, encourage them to grow and provide appropriate services. Mass tourism growth was encouraged in the third plan (1973-1977), with the government allocating public land for investors to develop.

In the next five years the growth rate slowed down due to inadequate marketing, lack of infrastructure to boost tourism and the economic difficulties the country was going through. In 1982, a new Tourism Encouragement Law was put into effect, which offered generous incentives to the investors, resulting in foreign investment and an increase in bed capacity, especially in the south and southwest regions of Turkey. Attention was also given to education and vocational training as well as improving the quality of the products and services. 
By 1985, the tourism authorities realised that sustainability of products and protection of environment were necessary. The next plan started to diversify the tourism offer, although the traditional mass tourism continued to expand. In the 1990-95 plan there was a clear emphasis on environmental sustainability and cultural protection as well as further diversification and human resource development.

During the 1990's the region faced serious crises, namely the Gulf War (1990-91), a civil war in former Yugoslavia (1991-2001) and devastating earthquakes in 1999 in northwestern Turkey. Nevertheless, tourism in Turkey showed its resilience and continued its growth during most of these years. In 1995, there were 7,083,000 international arrivals, with foreign exchange earnings of US\$ 4,957 million. However, 1999 saw an abrupt decline of 25\% in international visitors from the previous year, from 8.96 million in 1998 to 6.893 million in 1999 (Yalol, 2015).

Since the Millennium the tourism authorities have been focussing on quality improvements, intensifying marketing, diversifying the products offered and improving accessibility to products by investing in air transport. Meanwhile tourism has been included in the national strategy "Tourism Strategy of Turkey-2023", announced in 2007, and which is enabling the sector to implement strategic planning, and to enhance public-private as well as nationalregional collaboration.

In the first fifteen years of this millennium tourism in Turkey grew substantially. Between 2000 and 2005 the number of international arrivals increased from 9.59 million to 20.27 million. In 2011 most of the South Mediterranean Countries recorded a reduction in the total contribution of tourism and travel to GDP, except Turkey which recorded the most important growth in the world, at 11\% growth, according to the WTTC (reported by Lanquar, 2011). Arrivals reached a record high of 39.81 million in 2014, with foreign exchange earnings of US\$38.766 billion (UNWTO, 2015). In that year, Turkey ranked as the $6^{\text {th }}$ most popular tourist destination in the world. The share of people employed in tourism (out of total employment) also improved steadily, from 5.3\% in 1990 to $7.7 \%$ in 2005 and 8.3\% in 2015, with more than 2,193,000 jobs. Over the 20 year period 1990-2010, the number of people employed in tourism grew by $219 \%$ while international arrivals increased by $439 \%$, indicating an increase in efficiency and productivity over this period.

Since then, Turkey has experienced a decline in international arrivals. Its problems arose partly from its location neighbouring the conflicts in Syria and Iraq. This has led to a series of terror attacks and a failed coup in July 2016. In consequence, Turkey's economically vital tourism industry has been significantly depressed with arrivals falling from its peak of 39.8 million in 2014 to 25.4 million in 2016. According to the Hoteliers Association of Turkey (reported in The Guardian, 2016), hotels experienced a decline of 50\% in bookings in 2016 during July and August - normally their busiest months, while according to the WTTC (2016), the contribution of travel and tourism to Turkey's GDP was $12.9 \%$ in 2015 but declined to $12.5 \%$ in 2016.

Research with European tour operators indicates considerable apprehension in the marketplace about travel to Turkey on the basis of personal safety. This has led to the downturn in levels of 
visitation despite Turkey's outstanding value-for-money as hoteliers and ground operators offer heavy discounts in order to entice tourists back.

Table 4.2: International Visitor Arrivals and Foreign Exchange Earnings - Turkey

\begin{tabular}{|c|c|c|}
\hline Year & Arrivals ('000) & Receipts (US\$ billion) \\
\hline 1995 & 7,083 & 4.957 \\
\hline 1996 & 7,966 & 5.650 \\
\hline 1997 & 9,040 & 7.002 \\
\hline 1998 & 8,960 & 7.177 \\
\hline 1999 & 6,893 & 5.203 \\
\hline 2000 & 9,586 & 7.636 \\
\hline 2001 & 10,783 & 10.067 \\
\hline 2002 & 12,790 & 11.901 \\
\hline 2003 & 13,341 & 13.203 \\
\hline 2004 & 16,826 & 15,888 \\
\hline 2005 & 20,273 & 20,760 \\
\hline 2006 & 18,916 & 19.137 \\
\hline 2007 & 26,122 & 21,662 \\
\hline 2008 & 29,792 & 26.446 \\
\hline 2009 & 30,187 & 26.331 \\
\hline 2010 & 31,364 & 26.318 \\
\hline 2011 & 34,654 & 30.302 \\
\hline 2012 & 35,698 & 31.566 \\
\hline 2013 & 37,795 & 36.192 \\
\hline 2014 & 39,811 & 38.766 \\
\hline & 39,478 & 35.413 \\
\hline & 25,000 & 22.1 \\
\hline
\end{tabular}

Sources: UNWTO Yearbook of Tourism Statistics, Compendium of Tourism Statistics and data files

\subsubsection{Crises Affecting Turkish Tourism}

Specific crises that have affected Turkish tourism over the last two decades fall into a range of categories including natural disasters, political unrest and disease outbreaks.

- 1999: Izmit Earthquake - This occurred in northwestern Turkey and affected a densely populated area, resulting in the death of over 17,000 people and rendering around half a million people homeless.

- 2003-2011: Second Gulf War - There is no clear evidence of any impact on tourism in Turkey during this period, with steady growth in arrivals, from 13.34 million visitors in 2003 to 34.64 million in 2011 (UNWTO, 2012).

- 2006: Avian Flu - This global pandemic had a significant impact on tourism to Turkey with international visitor arrivals declining by $7 \%$ to 18.9 million from the previous high 
point of 20 million in 2005. Tourism from European markets was badly affected, with arrivals from the Netherlands declining from 250,000 to 100,000 over this period.

- 2011 to Present: Syrian Civil War - The ongoing civil war in Syria is part of a wider wave of unrest starting from the 2011. The Syrian crisis has a direct impact on Turkey in more than one way. Besides the problem of refugees that it has to deal with, the country recently was a victim of terrorism partly related to the Syrian conflict. Although Turkish tourism has proved resilience to several crises including social unrest and violence, the impact of repeated terrorist attacks and the upheavals of the last two years have proved to have a significant negative impact on tourism.

- 2015: Downing of Russian Warplane - In November 2015 a Russian Su-24 attack craft was shot down by a Turkish F-16 in the Turkey-Syria border area. Russia responded by applying economic sanctions on Turkey, including a travel ban to Turkish holiday destinations. However, the number of Russian tourists to Turkey in 2014 was 4.5 million, which is only $40 \%$ of the total decline in arrivals from 2015 to 2016 , indicating that other factors such as the frequent terrorist attacks, the political uncertainty and the image of the country played a major role in the depression of the sector in 2016. As the conflict between Russia and Turkey nears a resolution, it is expected that in 2017 Russian visitors will return. Whether that will be enough to restore the tourism industry will only be determined at the end of the 2017 tourism season (Ozen, 2016).

- 2015: Various Terrorist Attacks - In 2015 the number of terrorist attacks of various intensities and source had a direct impact on tourism in Turkey which extended to the following years. In general terms tourism recovers more quickly if terrorist attacks are not repeated (as discussed in Sections 1 and 2). But in 2015, the attacks were frequent, therefore the impact was felt with more than $30 \%$ fall in the number of the European visitors who comprise over a half of the international arrivals to Turkey (Lowen, 2016).

- 2016: Coup Attempt - A coup attempt by terrorists took place in Turkey on 15 July 2016.

Source: Cokcevik, pers. comm. 2017

\subsubsection{Recovery from Crises in Turkish Tourism}

Up to 2015, the Turkish tourism sector demonstrated resilience in recovering from the various crises that had occurred over recent decades, although they may have prevented the country from maximising its full potential as a tourism destination. However, the combined impacts of the Syrian Civil War and the 2016 attempted coup d'état have combined to form the worst crisis experienced so far, impacting on perceptions of Turkey and contributing to a significant (39\%) downturn in visitor arrivals in 2016 (Cokcevik, pers. comm. 2017).

The wider regional crisis has also had a cumulative (negative) impact on the image of Turkey in the country's main source markets, including its proximity to Syria. In particular, terrorist activities have raised concerns about safety and security generally. 
To counter the decline, Turkey is intensifying its overseas marketing efforts and seeking to diversify its source markets with increased emphasis on the Middle East and Asian markets (Cokcevik, pers. comm. 2017). Specific initiatives have been:

1. Cooperative Marketing Plan - Following the Avian Flu outbreak in 2006, a US\$50 million marketing campaign was organised in Turkey's key markets. The campaign was funded $50 / 50$ by the government and the tourism industry. Marketing activities included advertising in key markets, public relations campaigns, and incentive tours.

2. Pricing - the price of hotel rooms and holiday packages were reduced in the aftermath of the Avian Flu epidemic and other crises.

3. Image Building - Particularly since the outbreak of civil war in Syria in 2011, Turkey has engaged in a programme of image building, comprising perception management in key markets through social media and familiarisation trips for tourism trade and media representatives. Specific initiatives have focussed on the cruise sector. In all cases, media, tour operators and cruise companies were appraised of security measures that had been put in place for foreign visitors to Turkey. However, the Ministry recognises that image building will require a sustained approach over the medium to long term.

4. 2016 Action Plan - In January 2016, the government of Turkey announced an Action Plan to counter the crisis impacting on the country's tourism sector, comprising a suite of interventions including:

- Direct Subsidies: US\$75 million in direct subsidies to the tourism sector, including 'flight support' for Group A certified travel agencies (US\$ 6,000 subsidy for a plane bringing 100 foreign tourists - i.e. US\$ 60 subsidy per capita). Initially, this subsidy applied to charter flights at certain airports but it has now been extended to a wider range of airports and some scheduled flights, and to cruise lines.

- Indirect Subsidies: The accommodation sector has been supported by indirect subsidies in the form of bank credits and tax postponement (US\$ 85 million has been provided in indirect subsidies). $30 \%$ of Turkey's accommodation is on public lands for which owners/operators pay an annual lease/rent. This rent has been deferred for 3 years. In the south-east of the country, which is less developed from a tourism perspective, the government has postponed all taxes (including certification fees).

- Employment Initiative: In the 2nd half of 2016, the government announced an employment package in response to job losses in the tourism sector in Anatolia. The package involved payment of wages and social security for 9 months, and also paid the wages of intern students. In 2017, the employment initiative was extended to tourism businesses around the country.

- Business Development Strategies: Many Turkish businesses have implemented new business strategies to remain competitive. These include product differentiation and repositioning. In the case of the latter, many tourism businesses have focussed their attention on the domestic market. 
- Risk and Crisis Plans: A number of larger Turkish tourism resorts and hotel groups have their own protocols to deal with crises. The Intercontinental Hotel Group, for example, has a Risk and Crisis Protection Team at its headquarters in London. Risk profile reports are consistently updated, and risk and crisis priorities are (in order of priority) to protect visitors/guests; protect the hotel brand and reputation; protect the investment (Arslan, pers. comm. 2017). The intercontinental hotel group's Risk and Crisis protocols for Turkey are substantially the same as those for other countries.

Other strategies put in place by the sector include:

- Communications - with staff, partners and customers to constantly reassure trade partners and guests that Turkey is a safe destination.

- Differentiation - By creating a significant difference during the time of crisis, tourism enterprises can be successful. This topic is dealt with in section 6.2.3.

- Sales - Review of 'lapsed' accounts with trade partners including travel agencies, tour operators, and wholesalers. Major sales pitch targeted at lapsed account holders to re-capture lost business and increase hotel occupancy rates (Arslan, pers. comm., 2017).

\subsubsection{Critical Success Factors in Resilience of Turkish Tourism}

The key factors which (until 2016 at least) allowed tourism in Turkey to remain relatively healthy are as follows:

- The commitments from various governments since the 1980's that tourism is a priority, with significant legislative, political and financial support allocated to the sector. These included government incentives to invest in tourism, which have encouraged local and foreign investors to play a larger role in the development of tourism establishments, especially beach resorts, bringing the number of beds to one million.

- Increased use of the internet to reinforce the country's positive image and reputation by enhancing official websites and making more use of social media. A particularly attractive Facebook site on Turkey for instance is 'Tourism \& Art \& Turkey', where a series of attractive photos and brief comments are posted. Gulbahar and Yildirim (2015) also found that Turkish hotels were prolific users of social media, particularly Facebook, but also Instagram, Twitter, LinkedIn and Foursqare (with hotels which were part of international chains more likely to use these channels than locally owned hotels). The result is that Turkey is among the top 10 destinations in the world, as ranked by social media users.

- The richness of the country in its cultural heritage, history, archaeological remains, landscape and natural beauty and beautiful beaches. 
- Though most international arrivals to Turkey come for sun/beach holidays, in recent years the country has become also known for cultural tourism, health tourism and spas, golf and other sports tourism, marine activities, and development of the MICE sector.

- Competitiveness in terms of variety of attractions, quality of products and services and value-for-money.

- Proximity to the main source markets of Europe, Middle East and North Africa and accessibility via good connections with most source markets, partly as a result of government investment in the national airline Turkish Airlines; this again is part of the prioritisation of the tourism industry.

- Similarly, the government and private sector have invested in creating better port facilities for cruise ships. Cruise Line International Association - CLIA (2017) research reports that the cruise industry is on the rise with the use of new types of cruise ships. The project of building 13 city ports in cooperation with Greek cruise ports will facilitate growth in this sector and build on an already significant market: in 2011 Turkey received 2.2 million cruise passengers.

- In recent years, because of political and social developments in the MENA region including the developments from 2010, many Western countries have applied extra restrictions on visas to citizens of countries in the region. This means that Turkey is well placed to attract tourists from Middle Eastern and North African states because of its Islamic culture, excellent halal food and affordable prices. It has encouraged the Islamic market by abolishing visas for people from some countries, while easing the process by allowing online applications for others.

- Turkey is a good business centre in terms of textiles and clothing for Muslim culture, with competitive prices. Visitors from MENA countries mostly stay in big cities especially Istanbul, where shopping is plentiful. They stay in hotels for short periods but for longer stays they normally get private flats and private accommodations, in proximity to shopping areas.

\subsubsection{Weaknesses and Threats to Turkish Tourism}

- The principal threat to tourism in Turkey is the image of insecurity, which caused a significant decline in the number of international arrivals in 2016 and which may extend to 2017.

- A longer-term risk is the emphasis until recently on mass tourism, which has resulted in intensively used beach resorts. The rapid and intensive construction of hotels has had environmental impacts on the beaches, other coastal areas, agricultural land and forests; the presence of large numbers of visitors also has social impacts on local communities (Kuvan and Akan, 2012). This may undermine the success of tourism in Turkey unless environmental management regulations are adhered to and product diversification is successfully achieved.

- A further weakness is that while tourism in coastal areas benefits the country's economy, it does not reduce inequality between regions (Tosun et al, 2003). 


\subsubsection{Conclusion}

Tourism in Turkey has grown steadily since the 1980s. The sector is mainly focused on mass tourism, with bed capacity of around one million supported by cultural attractions and other activities. In recent years, the authorities have recognised the need to diversify its offer, expanding health and spa tourism, marine activities, golfing and MICE tourism. The 'Tourism Strategy of Turkey-2023' emphasises diversification of products and the sustainability of tourism, focusing on different regions with a new approach away from the traditional 'Sun, Sea and Sand' mass tourism. The strategy also attempts to increase the resilience of the sector by involving a wider range of stakeholders from local communities and civil society in the planning and implementation of tourism in order to minimise environmental and socio-economic impacts (recommendations made by Cetinel and Medet, 2009).

UNDP and the Ministry of Culture and Tourism of Turkey have a longstanding partnership since 2007, focusing on various segments of tourism for local economic development. "Future is in Tourism" Project which is being implemented in partnership with the Ministry of Culture and Tourism, UNDP and one of the leading entrepreneurial Turkish group sets a good example and an ideal model for the private and, public sectors, as well as improving NGO partnerships as they play a great role in developing community based tourism implementations.

"Future is in Tourism" is designed to provide local tourism actors and NGOs with necessary guidance, tools and resources to strengthen their capacities in order to contribute to the sustainable tourism development through partnerships with public and private institutions.

Although tourism grew rapidly until 2015, since then the country has been hard hit by a series of terrorism attacks, leading to an abrupt decline in international tourist arrivals. In January 2016, the government of Turkey announced an Action Plan to counter the impacts of the crisis on tourism, and currently the authorities are intensifying their marketing efforts to restore the image of the country. Meanwhile they are expanding their marketing efforts to Asia and the Middle East. 


\section{3. $\quad$ Case Study 3 - Tunisia (Field study)}

\subsubsection{History and Development of Tourism in Tunisia}

Since the early years of modern Tunisia, tourism has been considered an important sector for the creation of employment and provision of foreign currency. The proximity of the country to Europe, its moderate weather most of the year, its sandy and undisturbed beaches, its history and human heritage, its political stability and the openness of the Tunisian people to other cultures were all factors which made tourism a priority since the early sixties.

In its development strategy of 1962, tourism in Tunisia was designed to appeal to a mass market focused around the all-inclusive package tour concept. In order to meet the increasing demand for resort tourism, the government undertook major hotel construction programme along its 800-mile coastline. During the 1970's and 80's accommodation provision grew very fast, from 4000 in 1962 to 34,297 in 1970 and over 100,457 in 1987 (Poirier, 1995; Ministry of Tourism and Handicrafts, n/d). By 1987 there were 443 hotels and 40,000 jobs in the sector, and international visitor arrivals had risen from 53,000 in 1962 to 1,875,000 in 1987 (Tourism Strategy, 2016), while foreign exchange earnings grew from less than TND 2.0 million per year in 1962 to TND 568.9 million in 1987, which accounted for $77 \%$ of the trade deficit for that year (UNWTO, 2012).

The level of investment in tourism sector grew by over $600 \%$ in a decade, from TND 10.5 million in 1977 to TND 63.0 million in 1987 (UNWTO, 2010). The majority of hotels were built in the vicinity of Tunis and the prime resort areas of Nabeul-Hammamet and Djerba. Most of the hotels were built along the coastline as resorts to accommodate European package tourists.

During this first period 1962-1987, tourism in the country mainly focused on mass tourism with organized and guided tours. With time and the evolution of social, political and economic situations in neighbouring countries in the 1970s and 1980s, the volume of visitors from Libya and Algeria also grew, attracted by the country's proximity, the good quality of its medical and tourism services, and closer cooperation between the Maghreb countries (Algeria, Libya, Mauritania, Morocco, Tunisia). Between 1977 and 1981, the percentage of international visitors from Europe decreased from $83 \%$ to $53 \%$, while the share of visitors from the neighbouring Maghreb countries rose from $10 \%$ to $42 \%$ over the same period. However, the average length of stay is less for Maghreb tourists than for Europeans, while many are visiting for business or medical purposes and hence do not stay in resort areas.

The political commitment in the early 1970's to create more jobs through tourism development led the government to adopt investment laws which encouraged the construction of beach resorts, increased the number of tourist arrivals and promoted foreign exchange earnings. In 1988 earnings from tourism amounted to TND 1,086 million, which accounted for more than $97 \%$ of the trade deficit. In general terms, in the late 1980's and early 1990's the tourism sector accounted for about $20 \%$ of the country's total foreign export trade on average. 
Tourism in Tunisia continued to flourish between 1987 and 2010, with investments in the sector rising from US\$ 53million in 1987 to US\$ 212 million in 2009. The number of hotels reached 856 with 240,000 beds in 2009 , while direct jobs in the sector rose to 96,000 and international arrivals almost tripled, from 1,875,000 in 1987 to 7,049,000 in 2008, although they declined slightly the following year in response to the global economic crisis. Foreign receipts were also on the rise with the official figure in 2008 nearing US\$3billion, up from US\$474 million in 1987 (see also Table 4.3). The largest groups were from France, Germany, Italy and the UK, with European visitors comprising around half of the total, while regional visitors were still mainly from neighbouring Algeria and Libya.

Table 4.3: International Visitor Arrivals and Foreign Exchange Earnings - Tunisia

\begin{tabular}{|l|c|c|}
\hline Year & $\begin{array}{c}\text { Number of arrivals } \\
(\mathbf{0 0 0})\end{array}$ & \begin{tabular}{c} 
Receipts (US\$ million ) \\
\hline 1997
\end{tabular} 4,26 \\
\hline 1998 & 4,718 & 1,414 \\
\hline 1999 & 4,880 & 1,608 \\
\hline 2000 & 5,057 & 1,496 \\
\hline 2001 & 5,387 & 1,605 \\
\hline 2002 & 5,064 & 1,523 \\
\hline 2003 & 5,114 & 1,583 \\
\hline 2004 & 5,998 & 1,970 \\
\hline 2005 & 6,378 & 2,063 \\
\hline 2006 & 6,550 & 2,275 \\
\hline 2007 & 6,762 & 2,575 \\
\hline 2008 & 7,049 & 2,953 \\
\hline 2009 & 6,901 & 2,773 \\
\hline 2010 & 6,902 & 2,645 \\
\hline 2011 & 4,785 & 1,805 \\
\hline 2012 & 5,950 & 2,227 \\
\hline 2013 & 6,269 & 2,191 \\
\hline 2014 & 6,069 & 2,359 \\
\hline 2015 & 5,359 & 1,354 \\
\hline 2016 & 5,724 & 1,082 \\
\hline
\end{tabular}

Sources: Ministry of Tourism and Handicraft Statistics, UNWTO statistics

To diversify the products and develop areas other than the coast, the tourism sector witnessed expansion in health and wellness tourism including thalassotherapy, golf and other sports, heritage and desert tourism. By 2009 Tunisia had 45 thalassotherapy centers, 10 golf courses, 6 marinas, nine airports and seven sea-ports distributed in 11 tourism regions.

The sector also saw restructuring through closer partnerships and cooperation between the public and private sectors, involving more stakeholders than before. This cooperation has facilitated the gradual development of the sector on the regional level and expansion of new 
products in the interior regions and the desert. In terms of human resources, investment in training also expanded, with the establishment of 8 state tourism training centers.

\subsubsection{Crises Affecting Tunisian Tourism}

Tunisia enjoyed political stability from the late eighties to 2008, during which period its tourism industry developed. However, since then a number of incidents have affected the sector.

2008 Gafsa Mining Basin: In January, people in the Gafsa phosphate mining area in southwestern Tunisia demanded social. The developments lasted for over six months. In 2008, tourism had reached a high point in terms of international tourism arrivals and earnings but in the following year arrivals declined by about 145,000 visitors and a loss of about US\$ 180 million. From then on, the unstable atmosphere cast its shadow on the tourism sector, impacting on the image of Tunisia as a safe destination and resulting in a decline in international arrivals from 6.9 million in 2010 to 4.78 million in 2011, and a decline in earnings of US\$ 840 million compared to the previous year. Tunisia was also affected by unrest in neighbouring countries from 2011 onwards, including the uprising in Libya which resulted in thousands of people fleeing to Tunisia to escape the fighting.

However, Russians and other East Europeans had gone through similar experiences to Tunisia in their own countries not long before and these markets proved more resilient to the crisis. In 2012, while arrivals from the traditional source markets of Western Europe declined, East European and Russian visitors significantly increased (Zouaoui, pers. comm., 2017). The estimated increase for 2012 over 2011 was 33\% for tourists from Russia, 66\% for Ukraine and $10 \%$ from the Czech Republic. Regional visitors from the Maghreb countries, especially Libya and Algeria, were also relatively stable, with $2.8 \mathrm{~m}$ in 2012, 3.2m in 2013 and 2.9m visitors in 2014.

Political Developments in 2010 Onwards: Although political developments took place in 2010 and onwards the image of Tunisia was somewhat restored. During 2014 tourist receipts increased by $10.7 \%$ in compared to 2013, reaching close to the level of 2010 .

Bardo Museum attack 2015: The Bardo Museum in Tunis was attacked by terrorists on 18 March with 22 people killed, mainly European tourists, and over 50 people injured (BBC News, 2015a). This was a particular shock as it was the first attack targeting international tourists. On March 29 tens of thousands of demonstrators marched through the streets of Tunis against terrorism with the participation of the President of France, the Italian Prime Minister and several other world leaders. The previous day a police raid on the group responsible for the attack killed 9 of its members, and several other actions were taken to improve the security and ensure safety of tourists. The impact on the image of the country was significant.

Attack in Sousse, June 2015: A gunman fired on tourists at the tourist resort of Port El Kantaoui, about $10 \mathrm{~km}$ north of Sousse, killing 38 tourists. The hotel was hosting over five hundred guests at the time, mainly from Western Europe (BBC News, 2015b). This crisis had an immediate impact as it happened in the middle of the holiday season. The UK government issued an 
advisory warning to its citizens not to travel to Tunisia, the sector suffered trip cancellations, and several hotels had to close. Other smaller and sporadic attacks which mostly targeted national guard, army or other security personnel led the President to announce a state of emergency on July $4^{\text {th }} 2015$.

Presidential Security Guard Shooting, 2015: At least 12 people were killed when a bus carrying the Presidential Security Guard was bombed in the city centre of Tunis on November 24. The attack was announced as a terrorist act aiming to undermine the government's authority. This represented a change of tactic by the terrorists, in choosing a target away from tourism, as the authorities had placed tight security in various tourist areas which made them more difficult to target. However, the attack further damaged the image of security and stability in the country, leading to more trip cancellations.

As a result of these attacks, 2015 ended with reduced visitor numbers and significant economic loss, with 5,359,309 visitors (25.2\% less than the previous year) and receipts of US\$1,354 million (35.1\% less than the previous year). The number of hotel nights decreased by $44.4 \%$, forcing many hotels to reduce their staff and struggle to survive, while many others had to close (UNWTO, 2016).

\subsubsection{Post Crisis Response: Towards Recovery of Tunisian Tourism}

In response to the decline in 2011, a vigorous promotional campaign was launched to restore the image of Tunisia as a safe destination, using public, private and social media, press and personal contacts with international tour operators. The campaign aimed at the recovery of mass tourism from the main source markets and for the development of winter tourism. With a serious commitment from the government and an increased budget for marketing, these intensive campaigns achieved positive results. Due to this and to relative stability in the country at the time, the sector started to recover during 2012 and 2013, with an increase of $32.8 \%$ in tourist receipts, $45.3 \%$ in hotel nights and 31\% in the number of arrivals in 2013 over 2012. However, the industry did not return to its peak levels of 2008, either in terms of arrivals or earnings, due to the further crises which occurred.

After the further decline in 2014-15, the government responded with several institutional and legislative decisions in order to support the tourism sector (Zouaoui, pers. comm., 2017). Among the actions taken were:

- Improvement in security arrangements, including arming tourist police; 1,000 security officers deployed for securing the tourist areas, hotels and beach resorts; security improvements in airports, ports, tourist vehicles and carparks, heritage sites, and checkpoints at the borders, including the installation of monitoring equipment such as cameras, security alarms and metal detectors in sensitive areas where tourists are present; training of tourism staff in how to improve security; strengthening of security in working areas by enforcing the use of identification badges for all staff working with tourists; strengthened coordination between various departments concerned with 
national security, namely the Ministry of Interior, the Ministry of Defence and those of the tourism sector.

- Diplomatic efforts have stressed that tourism security measures are being implemented to secure tourists' safety while visiting the country, including inviting foreign ambassadors in Tunis by the government to be updated about the situation.

Other actions taken to help the tourism sector minimize its losses and recover from the crises are:

- An appeal to Tunisian citizens from within the country or living in foreign countries to take holidays in Tunisia. This has increased hotel nights taken by domestic tourists to almost 5 million nights, while the number of Tunisians coming from overseas for holiday in Tunisia was nearly one million (Zouaoui, pers. comm., 2017). Several hoteliers have offered package deals for domestic travellers in order to attract Tunisians to spend their holidays in Tunisia.

- To encourage regional tourism, the Ministry of Tourism is planning to improve the border infrastructure with neighbouring countries in order to make crossing easier and more comfortable in the expectation of attracting more visitors to drive to Tunisia from neighbouring countries, namely Algeria and Libya. However, the average length of stay per visitor to Tunisia has dropped from 6.6 nights to 4.7 nights, which is partly due to the changed reliance on the regional market. The authorities are working on diversifying the visitor's itineraries so that a combination of attractions in proximity with beach resorts can be visited.

- A new promotion and marketing policy aimed at enhancing the image of the destination and repositioning it on an international scale, including:

a. Live footage showing peaceful scenes from Sidi Bu Said, Hammamet and the desert oasis of Touzer screened simultaneously on graphic panels in several source countries - London, Paris, Berlin, Brussels and Milan - as part of an attempt to send a message that Tunisia is safe to be visited (Wismayer, 2016).

b. Bloggers and travel enthusiasts were invited to visit tourism attractions in Tunisia with an agreement to post video clips on YouTube expressing their own experience as a means of marketing through social media.

- In order to ease access for more visitors to visit Tunisia, the government abolished entry visas for citizens from several African and Gulf state countries.

- The government took steps to assist hoteliers who had trouble paying their debts by rescheduling their payments, or offering government-backed loans to finance activities through 2016. Value-added tax may be brought down as well. The government has also initiated an upgrade program to improve the hotel sector competitiveness and profitability and to stimulate growth in terms of foreign currency earnings.

- The government is planning on full implementation of "open skies"agreement with EU by the end of 2017 (Zouaoui, pers. comm., 2017). 
Estimated arrivals for 2016 are 5,724,021, representing an increase of $6.8 \%$ over the previous year, which a positive sign of recovery. WTTC (2017) statistics show that the total contribution of Tunisia's Travel \& Tourism sector to GDP in 2016 was $13.6 \%$, while its total contribution to direct and indirect employment was $12.6 \%$, with 430,000 jobs. The authorities expect to see further recovery in 2017, with a forecast of 6.5 million international tourists.

\subsubsection{Critical Success Factors in Resilience of Tunisian Tourism}

There are several aspects of the Tunisian tourism system which give it strength and resilience. The principal ones are:

- Public support for the government in its fight against terrorism, which was expressed by thousands of people who came out in big demonstrations denouncing terrorism.

- International support for Tunisia in its war against terrorism. After the Bardo Museum attack in March 2015, a big demonstration took place in Tunis with thousands of people opposing terrorism, with the participation of international leaders in showing political and moral support for the Tunisian people. Granting the Nobel Peace Prize to a group of Tunisian leaders was another demonstration of international support for the country.

- Support from neighbouring countries, especially from the Algerians who have supported the tourism sector in Tunisia by coming in thousands to take their vacations in Tunisia instead of other destinations that they customarily visit.

- Strong commitment and leadership by the government to address structural and institutional challenges within the sector by introducing a development plan with important reforms such as accessibility, product innovation and diversification, with regional specialisms, quality and training; promotion and sector restructuring and modernization (Oxford Business Group Studies, 2017).

- As part of this effort, the Ministry of Tourism and Handicraft held several regional stakeholder debates on tourism during 2017, in order to agree an approach on how to build a shared strategy for development. These debates had six themes which were: (a) access to destinations; (b) communications and promotion; (c) sustainable tourism; (d) quality of tourism products; (e) innovation and diversity of products and (f) development and qualification of tourism establishments. Six regional workshops took place within the country while the final one took place in Paris to include all the overseas stakeholders. It was intended for the debates to feed into an effective plan of action for developing tourism in Tunisia with the objectives of competitiveness, profitability and sustainability (Boussetta, pers. comm., 2017).

- Full development of the new products will need time, financial and well-trained human resources, but the sector is not starting from scratch. Some international brands such as Marriott Hilton, Movenpick, Golden Tulip, Sheraton and other high-end establishments are already operating in Tunisia which could expand in other areas of the country and participate in the development of business tourism and MICE tourism. Some new hospitality infrastructure has also been established in recent years with small-scale accommodation such as guest-houses, boutique hotels and rural lodges.

- In 2009, Tunisia already had 45 Thalassotherapy centres, with some new health projects scheduled for development in the Tunisia 2020 plan, including development of 
healthcare complexes.

- In 2001 The Japan International Cooperation Agency (JICA) studied in detail 'upgrading the condition of cultural, ecological and Saharan tourism resources', and itemized the important segments of cultural, ecological and desert tourism with evaluation of each in terms the potential, target market, and infrastructure. Several projects have also been put forward for development within the Tunisia 2020 plan by the private sector while others could be developing jointly with public sector.

It is expected that the reforms under discussion will satisfy market requirements and be able to offer competitive and sustainable tourism for the medium and long term. With the growing international tourism industry, UNWTO's long-term outlook expects tourist arrivals to Africa to reach 134 million by 2030, and Tunisia will be in a better position to retain its share in the Mediterranean tourism market (UNWTO, 2016).

\subsubsection{Weaknesses and Threats to Tunisian Tourism}

The main challenge that Tunisian tourism is facing today is the image of the country being unsafe. Until this image is changed positively, the sector will continue to suffer weakness. The issue is partly due to Tunisia's proximity to unstable areas in the wider region.

Tourism in Tunisia has relied for a long time on a single mass tourism offer. To effect a shift to more diversified product offer away from the coastal resorts, Tunisia will need major investments in infrastructure, which may take time under the current economic situation. A further weakness is that the national airline is not developing its capacity nor making any profits. If the sector finalises the "Open Sky" arrangement by end of the year, the national carrier may become even less competitive.

\subsubsection{Conclusion}

Prior to the political developments in 2011, Tunisia attracted up to seven million tourists every year. The political stability, low cost, proximity and good climate had attracted holidaymakers for the previous fifty years. However, on the outbreak of violence in late 2010 which led to the developments in 2011, the sector was hit hard, especially in terms of European source markets.

In the following three years the tourism authorities campaigned intensively to market the country as a safe destination, which led to gradual recovery in 2012-14. The indications are that the sector is quite resilient to the political instability that the country went through in 2011 hence the recovery did not take long. In 2015, however, the country was hit by terrorist attacks targeting foreign tourists. The industry suffered considerably during 2016 as a result, but by 2017 - in spite of the continued imposition of foreign office travel advisory warnings in many source markets - an increase in flights was reported and described as a 'surprise boost' for Tunisian tourism (Calder, 2017), while the government authorities anticipated a 30\% rise in arrivals compared to 2016 (Reuters, 2017). 
The authorities are now working to diversify the country's product offer by expanding on heritage tourism, desert tourism, ecotourism, senior citizen and health and wellness tourism, with an emphasis on individual travellers and closer partnership with local communities and stakeholders in various regions. The aim is to shift the focus away from the coast in favour of more regional promotion, in order to send a clear message that Tunisia has a more diversified product to offer besides sun and sea and beach resorts.

Meanwhile, the authorities are continuing their extensive marketing efforts. Besides the traditional markets in Europe, marketing campaigns are being extended to the emerging markets in Russia, eastern Europe and neighbouring countries of North Africa as well as exploring new markets such as China, Middle Eastern countries and Sub-Saharan Africa.

Overall, the Tunisian tourism system has demonstrated some of the key factors of resilience, in that the government has been proactive in leading on an inclusive approach to stakeholders and funded promotional campaigns aimed not just at restoring the country's tourism offer to its preexisting situation but at encouraging evolution towards a renewed and more diversified product. Thus, the official tourism website www.tourismtunisia.com shows images of heritage sites, gastronomy and desert landscapes as well as the more familiar beaches and resort hotels. At the same time, the government has addressed the specific concerns of tourists and the tourism industry by improving security at locations most likely to be frequented by tourists. It is too early to draw firm conclusions about the success of these measures, but the signs for 2017 are positive. 


\subsection{Case Study 4 - The Gambia (Desk study)}

\subsubsection{History and Development of Tourism in The Gambia}

The Gambia lies on the west coast of Africa and is the smallest country in mainland Africa. It stretches for around $350 \mathrm{~km}$. along the River Gambia, measuring just 24-48 kms. in width and entirely surrounded by the Republic of Senegal apart from along its coast. It has a tropical climate with distinct wet and dry seasons: the dry period (November to May) coincides with winter in the northern hemisphere and forms the principal tourism season.

The Gambia became independent from Britain in 1965. It was soon clear that over-reliance on a single cash-crop (groundnuts) was leading to significant economic problems (Bah and Goodwin, 2003), since the value of primary products was fluctuating. By then, most other countries were diversifying their economy. Advances in aviation technology were allowing passenger jets to travel further afield from source markets, and European holiday-makers were increasingly ready to venture beyond the shores of Europe for their annual vacation. Tourism was thus seen as a way to address The Gambia's economic weaknesses.

The country was well placed to appeal to North European markets because of its white, sandy beaches backed by an unspoiled natural environment, at only around 6 hours flying time from the principal generating countries and in a similar time zone. However, it it was relatively distant from key markets, there were perceptual barriers to overcome since Africa was unfamiliar to most Europeans, and it lacked the financial capital, infrastructure and human resources to develop as a destination without outside intervention. By the early 1970s the government therefore embarked on lobbying and attracting foreign investors to invest in tourism, including hotel development. By way of encouragement it offered incentives such as tax holidays, duty waivers and exemption from taxes (Dieke, 1993).

This policy coincided with the search by Europe-based tour operators for destinations beyond the shores of Europe with nice beaches, good levels of sunshine, a supply of workers willing to be trained in basic hospitality skills, and a stable government regime. The ensuring pattern of resort-based package tours set the framework for a low-cost model where a high percentage of the holiday cost accrued to the international airlines, hotel companies and tour operators rather than to the local economy.

The principal focus of infrastructure and hotel construction was the Tourism Development Area, a $10 \mathrm{~km}$ strip around the bay-shaped mouth of the River Gambia estuary and the Atlantic Ocean. The area was dedicated to the development of tourism facilities only. Foreign companies invested heavily in tourism and controlled the majority of the tourism-related businesses, including hotels, guest-houses, bars and restaurants, tourism service facilities, and souvenir shops. Managerial staff at that time came mainly from overseas, while local people were employed as unskilled workers.

The two decades from 1972 saw steady growth in tourism to The Gambia, reaching a peak of 
almost 90,000 visitors in 1994 and providing around 7,000 jobs (Sharpley, 2007). However, benefits to the local economy were limited due to high leakages and the high costs of meeting the expectations of tourists in terms of food, other supplies and infrastructure.

A military coup in 1994 and a contested transition of power in 2017 had short-term effects on visitor arrivals, but by then, Gambia has become established as a sun, sea and sand winter destination for people from Britain (which provides around 50\% of arrivals), Scandinavia, and other north European countries. Access from these markets is dependent on charter flights and package holidays organised by international tour operators: around $84 \%$ of arrivals are on allinclusive package tours (Mitchell and Faal, 2007). Tourism numbers overall are relatively small, never having risen above a peak of 171,000 in 2013 (see Table 4.4).

Table 4.4: International Visitor Arrivals and Foreign Exchange Earnings - The Gambia

\begin{tabular}{|c|c|c|}
\hline Year & Arrivals & Receipts (US\$) \\
\hline 2000 & 79,000 & Not available \\
\hline 2001 & 57,000 & Not available \\
\hline 2002 & 81,000 & Not available \\
\hline 2003 & 89,000 & $58,000,000$ \\
\hline 2004 & 90,000 & $51,000,000$ \\
\hline 2005 & 108,000 & $59,000,000$ \\
\hline 2006 & 125,000 & $69,000,000$ \\
\hline 2007 & 143,000 & $87,000,000$ \\
\hline 2008 & 147,000 & $80,200,000$ \\
\hline 2009 & 142,000 & $64,000,000$ \\
\hline 2010 & 91,000 & $80,000,000$ \\
\hline 2011 & 106,000 & $92,000,000$ \\
\hline 2012 & 157,000 & $99,000,000$ \\
\hline 2013 & 171,000 & Not available \\
\hline 2014 & 156,000 & Not available \\
\hline 2015 & 135,000 & Not available \\
\hline
\end{tabular}

Sources: UNWTO

By 2004 , tourism provided 16,000 jobs (Republic of The Gambia, 2006) and an estimated US\$ 40 million in foreign exchange, but there was concern that the sector was generating less wealth for the country than it could have done because of the high leakages; large shares of tourist expenditure are repatriated to the countries where multinational hotels, international tour operators and foreign airline companies originate. A Tourism Master Plan produced in 2006 aimed to address this by diversifying the tourism sector, extending the season, and developing better links along the local supply chain in order to reduce reliance on imports. A small but influential NGO - the Association of Small Scale Enterprises in Tourism (ASSET) - was established in 2000 to promote better links between the informal economy of craft markets, beach-vendors, tourist guides and other micro-entrepreneurs, and the formal sector of resortoriented package tours. 
Mitchell and Ashley (2007) carried out a review of the tourism value chain within the Gambian tourism economy and found that despite the high leakages, a considerable proportion - around $14 \%$ - of in-country spending for goods and services accrues to non-managerial staff and entrepreneurs. This is a significant flow, even though on the face of it The Gambia appeared to be a case study of where tourism does not benefit the poor because of weak support and governance from the public sector, the relatively small number of arrivals, and the dominance of cheap package holidays operated by a few European tour operators.

\subsubsection{Crises Affecting Gambian Tourism}

The characteristics of the tourism industry in The Gambia - in particular its reliance on a small number of source markets and a narrow offer of beach resort tourism - leave it particularly vulnerable to stresses. The main issues which have affected the country or which may do so in the medium term are as follows:

- The developments in Gambia took place during the peek season of tourism have adversely effected the tourim arrivals and revenues.

- The Ebola disease outbreak in 2014 caused considerable disruption to destinations across Sub-Saharan Africa. As the outbreak started fairly late in the 2013-14 tourism season, the major effects were felt by The Gambia in 2014 and 2015 (Mizrachi and Fuchs, 2016). According to government sources, the effects of the outbreak are still being felt in lower arrival numbers than would have been expected otherwise (BeyaiRaji, pers. comm., 21 April 2017).

- A further source of stress to the tourism system is the impending crisis of climate change. In 2003 it was already flagged up that The Gambia is one of the countries most vulnerable to sea-level rise due to climate change. Because almost its entire tourism infrastructure is located along the coast, a rise in sea-levels will significantly affect the tourism product and the country's infrastructure generally, including inundating the capital, Banjul (Jones, 2003). This matter is the principal cause for concern of the tourism authorities (Beyai-Raji, pers. comm., 21 April 2017).

\subsubsection{Recovering from Crises in Gambian Tourism}

The collection of economic data and other statistics on the Gambian tourism industry has been inconsistent, but it is nevertheless clear that the visitor arrivals recovered quickly after the 1994 coup. Subsequently, however, the industry lost momentum, with significant fluctuations in annual arrival figures in the period 2000-2005 (Sharpley, 2009). Although there was some recovery after this, volumes have again tailed off, stagnated or declined since 2008.

In order to recover from the most recent shock to the tourism system, in January 2017 the Gambia Tourist Board (GTB) engaged PR firms in their main markets and has been working closely with tour operators to promote positive stories about the country in time for the 201718 season. Efforts have included familiarization trips for journalists and tour operators in order to try and eliminate the 'fear factor' (Njie, pers. comm., 21 April 2017). The GTB is working 
closely with other government departments and stakeholders such as the Gambian Hotel Association. They were able to reduce landing fees at the main airport, while hoteliers reduced their hotel costs. A further action is to reduce the cost of licensing hotels for the whole of 2017. The GTB has also worked with other government authorities to reduce the cost of aviation fuel and the cost of energy and water in hotels (Bah, pers. comm., 21 April 2017). All these measures allow tour operators to increase their competitive edge by reducing package prices.

\subsubsection{Critical Success Factors in Resilience of Tourism in The Gambia}

As can be seen from the arrival figures, there has been no growth in overall arrival figures over the last decade, in contrast to the strength of international trends globally over the same period.

On the other hand, people caught up in the January 2017 crisis reported being well taken care of by local hotel staff and tour agents over that period, so that they felt reassured and in no personal danger (Stanford, pers. comm., 22 March 2017). One of the most positive aspects of Gambian tourism is that there are many dedicated and well-meaning people (both Gambians and others) working to support the sector. In particular, there are knowledgeable tour operators in the principal source markets. For instance, the UK-based operator The Gambia Experience (part of the Serenity Holidays Group) carries $60 \%$ of UK tourists to The Gambia and runs scheduled flights there throughout the year, in contrast to most other tour operators which only run flights during the high season (November-May). This operator has worked hard to diversify its product and now includes an 'eco-retreat' and a floating lodge on the River Gambia in addition to the more standard beach resorts. They also run excursions to allow their customers to interact with local people, for instance visiting schools or fishing villages or learning how to cook authentic meals (www.gambia.co.uk). This kind of initiave may encourage other operators in the country to diversify and thereby create a more resilient tourism system in the future.

The Gambia has long been the focus of efforts by advocates of responsible tourism, who have worked with local people to create more sophisticated and equitable tourism systems. For instance a British university was funded by the World Bank in 2012-17 to carry out a feasibility study and capacity-building for a 5-day excursion linking natural and cultural sites along the River Gambia (the 'Ninki Nanka Trail') (McCombes, pers. comm., 18 April 2017).

The organisation of tourism is another cause for optimism. The Gambia Tourism Authority (GTA) is an arm of the Government but funded by the private sector, in particular the largest ground handling agents. GTA staff are becoming increasingly well-educated and aware of opportunities to develop and diversify their industry. The reliance on the UK market is waning slightly: in $200462 \%$ of tourists came from the UK but the proportion now stands at $45 \%$, with the Dutch market the second largest. Markets in Belgium and Poland are also expanding (BeyaiRaji, pers. comm., 21 April 2017). 


\subsubsection{Weaknesses and Threats to Tourism in The Gambia}

The population of the country is relatively small (1.9 million) and in 2015 it lay in $173^{\text {rd }}$ place (out of 188 countries) on the UN's Human Development Index. The challenges are also because the country has few natural resources on which to base a more diversified economy. Even in 2015 , the export of groundnuts, cashew nuts and related products accounted for $53 \%$ of the total value of the country's exports (Republic of The Gambia, 2016).

The heavy dependence of The Gambia on foreign-owned tour operators as intermediaries with the international market is a further weakness, but attempts in the 1990s by the government to regulate the growth in all-inclusive holidays led to the withdrawal of a major German tour operator, followed by protests from other European tour operators. In the face of threats of reduced business to the destination, the policy was abandoned (Wheatcroft and Francis, 2011).

A further possible cause of weakness is ascribed to increasing fears of terrorism and Islamophobia by North European markets (Mitchell and Faal, 2007; see also Section 3). However, since the principal outbound tour operators make little mention of the country's prevalent religion, it is probable that the sluggish demand is more closely related to the strongly competitive market environment, and to the search by European markets for more sophisticated and experiential forms of tourism, while Gambian tourism has failed to keep pace with these developments.

The World Economic Forum (2017) assessment of tourism competitiveness places The Gambia in $112^{\text {th }}$ position (out of 136). It scores especially poorly in terms of its cultural resources and business travel $\left(128^{\text {th }}\right.$ position), the Human resources and labour market (114th) and international openness $\left(120^{\text {th }}\right)$.

\subsubsection{Conclusion}

Despite structural weaknesses in the Gambian tourism sector, those most closely involved in it remain optimistic. The British tour operators Thomas Cook and The Gambia Experience are intending to maintain or increase capacity for the 2017-18 season, while the largest outbound operator from Poland to The Gambia has also confirmed an increase in flight capacity. Senior staff from the GTB have confirmed a larger budget for marketing and product development. In particular, they expect to diversify their offer to encompass more cultural and ecotourism products away from the coastal strip and will continue to welcome both foreign and domestic investors. They also expect to emphasise the message that The Gambia is an extremely safe destination (Beyai-Raji, pers. comm. 21 April 2017).

The strongest lesson learned from the most recent crisis is that the tourism authorities need to have an inter-departmental emergency response programme in place in order to ensure the safety of their customers in the event of an emergency. 


\section{CASE STUDIES - Non-OIC Countries}

In this section the case studies carried out for this report into tourism crisis management in four countries which are not members of the Organisation of Islamic Cooperation will be discussed, namely South Africa, the United Kingdom, Thailand and Sri Lanka. Field research was carried out in South Africa, while the other three countries were investigated via desk research into the academic and grey literature and news reports. As in Section 4, each case study starts with a brief overview of the history and development of tourism in order to set the context for the crisis situations that have arisen. The crises or disasters that have occurred and their impact on tourism are then outlined, followed by measures taken by the government and industry of the countries to recover.

\subsection{Case Study 1 - South Africa (Field study)}

\subsubsection{History and Development of Tourism in South Africa}

South Africa became a major tourism destination relatively recently, as leisure tourists began to arrive in significant numbers only after the end of the apartheid regime in 1994.

The country has a varied and scenic tourism product in large part because of its topographical and biological diversity, with white sandy beaches, mountain ranges, savannah grasslands and deserts such as the Kalahari and the Great Karoo. Much of its ecological wealth is protected in state-owned national parks and private protected areas. Safari tourism is a major sector because it is relatively easy to spot the iconic 'Big Five' species, i.e. lions, leopards, elephants, rhino, and Cape buffalo, as well as numerous other charismatic animals such as giraffes, antelope and meerkats. The services and facilities for wildlife-watching are amongst the best in the world, ranging from 'mass safari' tours to high-end stays on private game ranches. Marine-based wildlife attractions are also popular, including whale-watching, scuba-diving and shark-cage diving.

Adventure sports and food and wine tours are also well developed, while the cities of Durban, Cape Town and Johannesburg have interesting museums and world-class shopping malls. Cultural tourism includes visits to the Townships, World Heritage Sites, and to sites of significance to the anti-apartheid movement and historically oppressed communities. Linked to this, the legacy of anti-apartheid and post-apartheid regime leader Nelson Mandela is highly influential, with Mandela's former prison on Robben Island inscribed as a World Heritage Site in 1999 and the Apartheid Museum in Johannesburg listed as the city's top attraction on TripAdvisor. Other important niche sectors include medical tourism and gambling tourism.

South Africa successfully hosted the FIFA World Cup in 2010, which was the catalyst for developing the country's experience, infrastructure and facilities as a sports tourism and MICE destination. Tourvest, the company that handled organizational aspects of the World Cup event, has gone on to become a major international player in destination management. 
In terms of its market, South Africa has the largest share of international arrivals in sub-Saharan Africa, with almost 9.5 million visitors staying at least one night in 2016 (UNWTO, 2017). Of these, just over 2.5 million originated from non-African countries, principally Western Europe $(60 \%)$, North America (16\%) and Australasia, China and India (14\%). The length of stay of these categories is commonly between 7-14 days and their average spend (in-country plus predeparture expenditure) is around R.65,000 (US\$ 4,930) per person. Regional arrivals by air (i.e. tourists from other Sub-Sahara African countries) totalled 635,950 in 2016, with a typical stay of around 6 days and expenditure per person per trip of R. 33,400 (US\$2,500). Meanwhile, landarrivals typically stay for 1-3 nights and spend just R. 6,200 per trip (US\$ 470) (Saunders, 2017). Land-arrivals are generally from countries within the Southern African Development Community (SADC), especially Botswana, Lesotho, Mozambique, Namibia, Swaziland and Zimbabwe. This category includes many people on VFR trips or who are working or studying in South Africa.

These figures make it clear that tourists from outside Africa are overall more valuable to the economy than others, and according to the 2015-20 Strategic Plan, these are the core target markets along with the higher-spending African markets such as Nigeria and Tanzania (South African Tourism, 2014).

Table 5.1 shows international visitor arrivals over the period 2005-16. Although the total number has risen by $26 \%$ over this period the growth has almost all come from SADC countries, while the more lucrative markets of Europe, the Americas, Australasia and Asia have remained somewhat static.

Table 5.1: International Visitor Arrivals and Foreign Exchange Earnings - South Africa

\begin{tabular}{|l|c|c|}
\hline Year & Arrivals ('000s) & Receipts (US\$ million) \\
\hline 2005 & 7,518 & 7,327 \\
\hline 2006 & 8,396 & 7,875 \\
\hline 2007 & 9,091 & 8,418 \\
\hline 2008 & 9,592 & 7,925 \\
\hline 2009 & 7,012 & 7,543 \\
\hline 2011 & 8,074 & 9,070 \\
\hline 2012 & 8,339 & 9,547 \\
\hline 2013 & 9,188 & 9,994 \\
\hline 2014 & 9,510 & 9,238 \\
\hline 2015 & 9,549 & 9,348 \\
\hline
\end{tabular}

Sources: WTTC, 2016; UNWTO (various); South African Tourism (various)

Figure 5.1 illustrates the disappointing non-growth of arrivals from these countries, with the reasons for this discussed below. 
Figure 5.1: Arrivals to South Africa from Outside Africa, 2005-15

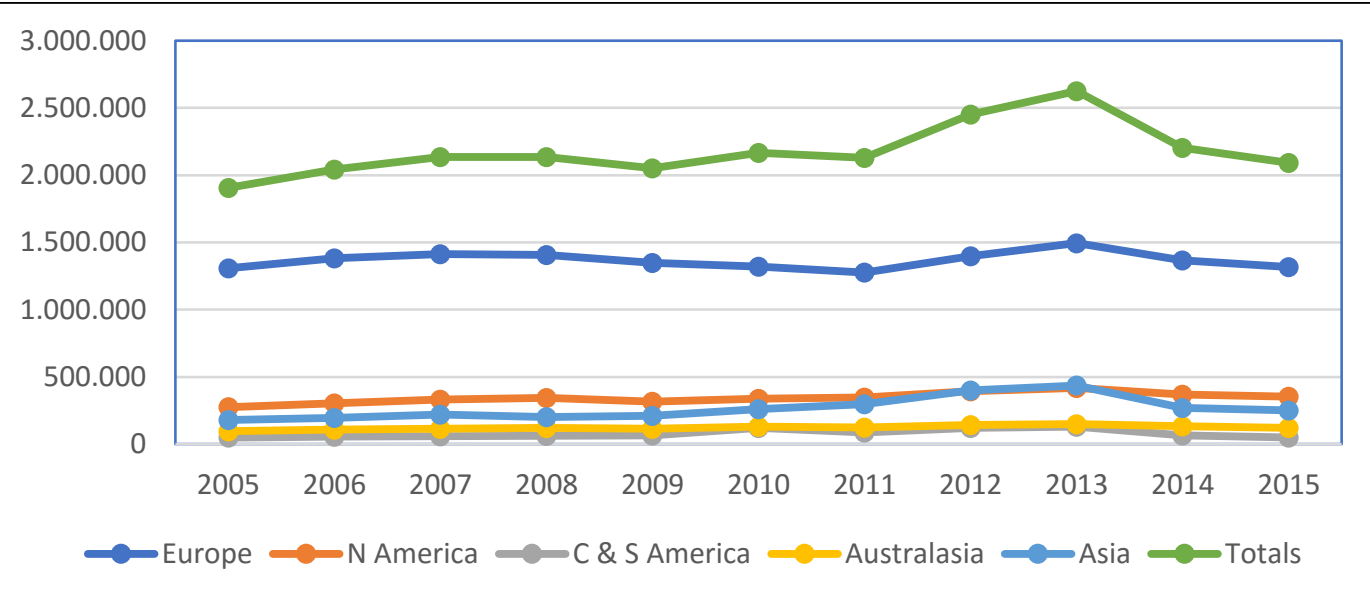

Sources: WTTC, 2016; UNWTO (various); South African Tourism (various)

To compensate for the sluggish growth in international markets, many tourism businesses have turned to domestic and regional markets. While this at least has allowed for businesses to survive and for some transfer of wealth between urban and rural areas, domestic tourists have a lower spend than international ones while regional visitors have a shorter length of stay in addition to a lower spend, meaning that these two groups cannot compensate for the foregone foreign exchange earnings.

In economic terms, tourism continues to make a significant contribution to national revenue despite its slow growth. Data from the WTTC (2017) suggests that direct expenditure from tourism contributes around 3\% to GDP, rising to $9 \%$ when direct and induced expenditure is taken into account, with around 5\% of employment in the tourism and hospitality sector although this does not include jobs in the informal sector. The WTTC forecasts that the contribution to GDP will rise to $3.8 \%$ by 2027 (direct share) and $11.5 \%$ (indirect share) and 6\% of employment (WTTC, 2017). These figures are particularly significant given that growth in the South African economy overall is slowing, with GDP growth rate of just $0.3 \%$ and unemployment at $26.5 \%$, and the downgrading of sovereign debt to sub-investment grade in April 2017 (World Bank, 2017).

Organisationally, the arm of South Africa's Department of Tourism responsible for promotion is South African Tourism (SAT). The principal private sector forum is the Tourism Business Council of South Africa (TBCSA), which groups companies right across the sector, and through which the Department of Tourism and SAT channel their messages and policies. In addition, there are other trade association such as the Southern Africa Tourism Services Association (SATSA), the South African National Convention Bureau (SANCB) and the Association of South African Travel Agents (ASATA). Additional influence comes from the office of Brand South Africa (BSA), established in 2002 and responsible for managing the overall image of South Africa overseas, with the aim of encouraging inward investment as well as tourism. BSA sets the overall brand for South Africa, which is picked up by South African Tourism, tourism associations and private companies. The current branding strapline is 'South Africa - Inspiring new ways'. 
The Department of Tourism follows the National Tourism Sector Strategy (2011-20) and the Tourism Strategic Plan (2015-20) to help it meet its objectives.

Around 450 tourism businesses levy a 1\% charge on services to their guests and clients to support South African Tourism's overseas promotional efforts. This is known as the TOMSA levy (i.e. 'Tourism Marketing South Africa') and is channelled to SAT via the TBCSA (Ramawela, pers. comm., 11 May 2017). This however forms only 6\% of SAT's budget: the remainder is covered by central government funding.

\subsubsection{Crises Affecting the South African Tourism Industry}

According to a 2017 report, South Africa is still judged to have significant untapped potential in terms of development in its tourism industry, but according to a Mintel (2017) report, its potential is threatened by a number of weaknesses. The principal ongoing challenges can all be classified as manmade crises rather than natural disasters: indeed David Frost, the head of SATSA, remarked that South Africa's tourism industry pain is self-inflicted (Frost, 2017, cited in Alfred et al, 2017). The main issues are as follows:

- The introduction in 2014 of stringent new visa requirements for visitors from China, India, Nigeria and other countries. Individuals from these markets are now required to apply in person for their entry visa rather than a travel agent being able to do so on their behalf. The introduction of the new rules saw a sharp drop in arrivals from China (down $38 \%$ in the first quarter of 2015), India (down 13\%) and Nigeria (down 15\%) in 2014/15 (England, 2015; Oxford Business Group, 2015). The regulations have since been relaxed after pressure from the Department of Tourism and the private sector and there has been some recovery in these markets, but overall the action was indicative of poor coordination between different government departments and with the private sector.

- A failure to understand and prepare for the characteristics of specific markets. For instance, $65 \%$ of the Indian market visits South Africa during the southern hemisphere winter in order to escape the hot season at home. Yet according to one tour operator "the SA consulate in Mumbai and High Commission in Delhi are never prepared for the annual upsurge in visa applications in high season - we warn them about it every year and they keep doing it" (Groenewald, 2017, cited in Alfred et al, 2017).

- New visa requirements were introduced for visitors from New Zealand in 2017 in an apparent 'tit for tat' retaliation because New Zealand had strengthened visa requirements for visitors from South Africa. This led to the cancellation of several group tours (Emmanuel, 2017).

- In addition, in 2015 it became a requirement for all children (under the age of 18) entering or leaving South Africa to have the written consent of both parents and to be in possession of an unabridged, original birth certificate at the point of entry - with a notarised translation into English if the original was in another language. An attempt to restrict child trafficking, this regulation was introduced without sufficient lead-time or consultation and caused considerable disruption to families' travel plans and negative 
publicity. Even in mid-2017 several vacationing families per week were being turned away from South African airports on arrival (Saunders, pers. comm, 11 May 2017).

- Industry commentators interviewed for this study remarked on the weak enabling environment for business provided by the government.

- Domestic tourism is also negatively impacted by the weak economy. According to the 2015-20 National Tourism Strategy, household debt-to-income ratio stood at 78.5\% in 2014, characterised by payment defaults and consumers under debt review. Domestic consumers are further experiencing erosion of their relative wealth because of the weakening currency (the Rand), which results in increased food and fuel prices and higher electricity tariffs, with further pressure from high interest rates. South Africa's unemployment rate of $26.5 \%$ contributes to the unaffordability of holidays. The growth in middle-class wealth and aspirations which is a pre-requisite for a robust domestic market is therefore absent. Partly as a consequence of the weak economy and partly because of increasing racial tensions, many younger South Africans from white ethnic groups are seeking new lives overseas by emigrating.

- According to several informants, the biggest issue affecting tourism to South Africa is 'crime'. Reports of shootings, hijackings, muggings, rape and other forms of violence create negative publicity, even though it appears that much of the violence is directed against migrant workers and residents rather than tourists. The National Tourism Sector Strategy (2011-20) admits that "the country has a real problem with crime and safety" (Dept. of Tourism, 2017) but stresses that incidents involving tourists are rare. Despite this, there is clear concern by visitors and potential visitors about personal security and safety, reinforced prior to arrival by advisory warnings from source market foreign offices, and when in-country by advice from accommodation and other tourism business owners not to walk around alone, especially after dusk.

- A further perceptual issue is that "Africa is seen as one country" (Nwokedi, pers. comm., 10 May 2017) so that when a crisis affects one Sub-Saharan African country, visitor arrivals to all of them contract. Thus, the terrorist attack on the Westgate shopping centre in Kenya in 2013 and the Ebola disease outbreak in West Africa in 2014 put downwards pressure on visitor arrivals - even though "Freetown [where the Ebola outbreak was centred] is closer to Paris than it is to Johannesburg" (Nwokedi, pers. comm., 10 May 2017).

Many of these issues date back several years. In 2000 it was already apparent that the hopedfor growth in tourism to South Africa after the end of the apartheid regime was failing to materialise, with publicity given to violent crime and bombings effectively keeping tourists away: "the challenge for the industry is to allay tourists' fears that they will be shot for their cameras" (The Economist, 2000). The situation improved to some extent after an international spotlight was thrown on the country during the 2010 World Cup, but according to industry commentators the two biggest challenges remain the perception of crime levels amongst overseas markets and the failure of government departments to consult with the industry. 


\subsubsection{Addressing Crises in South African Tourism}

As shown above, visitor numbers overall to South Africa have generally risen year on year for the last decade except in 2009, when the decline was due to the global financial crisis, and 2015, because of the impact on important markets of the new visa regulations. A closer look at the figures however reveals that the principal increase has come in the segment of 'African Land' tourists, i.e. people from SADC countries, many of whom visit for just 1 day for small-scale trading purposes. This leaves businesses which rely on forms of tourism other than VFR and small-scale trading in a challenging situation. They have become practised at having to address South Africa's poor image overseas, especially in Western markets. Actions they take include:

- Lobbying government departments responsible for policies and regulations perceived as obstructive or damaging to the free movement of tourists, such as the stringent new visa regulations (for which the Ministry of Home Affairs is responsible). This is done by individual companies or through trade bodies such as the TBCSA.

- Creative and frequent use of 'good news' stories by public and private sector via bloggers and press releases, including efforts to get across the message that attacks on tourists are rare. Some of these stories are tapped from a website entitled "South Africa: the Good News" (https://www.sagoodnews.co.za/) set up by a South African to counter negative stories picked up by the media.

- Use of professional PR agencies to 'manage the message'. In 2014 a PR agency - Bell Pottinger - was given a three-year contract to shift the perception of South Africa in the UK away from it simply being a safari destination. The images currently presented on the homepage of SAT's website in the UK illustrate this approach: they depict sporting, adventure, culinary and cultural activities rather than safari tours. Unfortunately, This campaign backfired spectacularly when it emerged in June 2017 that the PR company was at the same time working for a different government group to whitewash financial transactions between politicians and the private sector (BizNews, 14 June 2017).

- Introduction in 2010 - in time for the World Cup - of a 'Tourism Safety Initiative' (TSI), which collects data on crimes committed against tourists and tourism businesses and works with the police and other government departments to try and reduce crime levels. The TSI is a private sector initiative introduced by SATSA and run by the TBCSA. Its vision is "To strengthen tourist and trade confidence in destination South Africa as a safe place to visit or travel and operate within" (TBCSA, n/d). However, according to one informant the TSI is no longer particularly active (Saunders, pers. comm., 11 May 2017).

- Introduction by SAT of a crisis manual with guidelines as to how to react in the event of a crisis such as a terrorist attack. This is an interdepartmental plan which is continuously updated, with training of heads of government departments carried out (Whitehouse, pers. comm., 11 May 2017). This initiative does not directly involve the private sector, but the TBCSA is kept informed of its existence. 


\subsubsection{Critical Success Factors in Resilience of South African Tourism}

Despite the negative publicity surrounding the economy and certain actions by the South African government, the outlook for the tourism sector remains reasonably optimistic. A 2015 business review supported the country's position as the leading destination in sub-Saharan Africa (Oxford Business Group, 2015). The principal factors in its resilience appear to be:

- A competitive place in the market due to its natural and cultural attractions.

- Good tourism infrastructure and experienced destination managers, partly as a legacy of the 2010 World Cup.

- Attractive and efficient convention centres in Cape Town, Johannesburg and Durban, enabling the MICE sector to host over 100 major conferences and other events per year.

- Effective marketing strategy which has helped build the country as a brand.

- Active and diverse business sector, from large hotel companies and safari operators to micro-entrepreneurs.

- Strong government involvement in building capacity to create products and engage in tourism, especially in peripheral regions (Malan, pers. comm., 9 May 2017).

- The favourable exchange rate with the Rand for people from most source markets.

In line with industry-wide trends, social media has become an important promotional tool and SAT has official channels on Instagram, Facebook, Twitter, Pinterest and GooglePlus, amongst others. The \#MeetSouthAfrica and \#WowSouthAfrica hashtags are used in traditional and digital advertising campaigns. The aim is to engage prospective visitors, encourage the social sharing of travel experiences in South Africa, and help enhance the country's brand identity.

These channels are certainly effective to some extent. For instance, there are fewer actual concerns about personal security than the perception of South Africa would suggest, as illustrated by discussions in the 3 months to May 2017 on The Lonely Planet's social media forum for independent travellers 'Thorntree'. The majority of topics (32 out of 36) were about suitable itineraries, travelling by bus or finding a travel companion, while only 4 intending travelers expressed anxiety about personal security. They asked about (a) the advisability of driving at night (the advice was not to do so partly because of the danger of running into wildlife and partly because hijackings are more common at night); (b) walking alone in cities and national parks as a solo female (it was generally said to be safer to join a group and avoid walking at night in the larger cities, but there were no real concerns in the daytime); (c) using public transport (generally said to be safe but Uber was advised in the cities); (d) walking around carrying cameras, etc. (the advice is to put expensive-looking goods in a plain bag, but that reports of 'rampant theft' were exaggerated and that South Africa's cities are no more dangerous for tourists than cities anywhere else in the world).

\subsubsection{Weaknesses and Threats to South African Tourism}

The World Economic Forum's 2017 assessment of the competitiveness of South Africa's tourism industry in relation to other countries concluded that its overall world ranking had slipped from 
$48^{\text {th }}$ out of 141 countries in 2015 to $53^{\text {rd }}$ out of 136 countries in 2017 . The principal reasons for the decline were the deterioration of safety and security and environmental sustainability (due to deforestation and loss of habitat). This latter is particularly worrying, given the centrality of wildlife and the environment to the country's tourism product.

Further threats to the continued success of South African tourism include:

- Continuing international perceptions that South Africa is unsafe. The National Sector Strategy Plan urges all tourism businesses to try and address the negative aspects which are occasionally focussed on by the media.

- A 2012 study found that 'National Image and Competitiveness' was the risk factor of most concern to South Africa-based tourism businesses, especially weak marketing by national and local authorities (Shaw et al, 2012), while the CEO of Brand South Africa commented that better alignment and brand positioning across all stakeholders responsible for promoting South Africa overseas is needed (Makhubela, pers. comm., 10 May 2017).

- Currency fluctuations, in particular the weaker Rand. On the one hand the favourable exchange rate with currencies from source markets can encourage greater numbers of tourists, but on the other operational costs - especially those based on imports - will rise (Emmanuel, 2017). According to an SAT (2009) report, devaluation after 2008 effectively caused a real decline in SAT's promotional budget for 2009 by R.78 million (approx. US\$ 7.5 million at 2009 rates).

- Overly bureaucratic government-run tourism organisations.

- Limited finance for the development of new attractions and infrastructure or for promotion. Public transport systems are poor and, although the gap has largely been filled by taxis, these remain unaffordable for most South Africans.

- Poor tourist information on less frequented destinations.

- Poor understanding of the value of tourists locally and nationally in peripheral destinations, and of the role (or existence) of domestic tourists. 'Tourists' are perceived as white and from elite groups: for instance in one of the South African languages, the term for 'tourist' translates as 'rich white person from far away' (Nwokedi, pers. comm., 10 May 2017).

- Variable quality of tourism products.

- Inconsistencies in the training/expertise of tourism employees and low entry rates into tourism by non-white South Africans.

- The low regard in which tourism-related jobs are held by many South Africans (Mintel, 2017).

- Perception by the private sector of a disconnect between the government's aim for an inclusive economy which will reduce inequalities between different sectors in society and the creation of a supportive and enabling business environment.

Overall, a study by Shaw et al. (2012) concluded that tourism businesses and government bodies need to collaborate more closely to address weaknesses in promoting a safe image of South 
Africa, and that government agencies need to show stronger leadership in keeping the private sector informed.

\subsubsection{Conclusion}

The government is aware of weaknesses in the industry, especially in terms of ensuring the effectiveness of tourism for poverty alleviation. Its National Tourism Sector Strategy acknowledges the central role of local government as a partner or stakeholder in growing the tourism sector, and according to Rogerson (2013) it has launched several initiatives aimed at supporting local government in tourism planning and implementation.

Unfortunately, the identified weaknesses - in particular the failure of the public sector to create an enabling environment - seem likely to prevent the potential of tourism to South Africa from being realized. In short, this is an example of how poor leadership is hindering attempts by private enterprises to respond to market forces. It is to be hoped that the underlying strength of the South African tourism offer - its remarkable range of activities and experiences, buoyed by good cooperation within the private sector - will allow at least some benefits to flow to the economy and people. 


\subsection{Case Study 2 - United Kingdom (Desk study)}

\subsubsection{History and Development of Tourism in Britain}

Britain was one of the first countries to develop a modern tourism industry with people travelling away from home for leisure purposes rather than for business, health or religious reasons, as had previously been the case.

The industry began in the mid-19th century and was stimulated by two factors: increasing numbers of people with sufficient disposable income to spend on consumer interests in addition to the basics of food, shelter and warmth; and the spread of the railways across the country. These connected the newly expanded cities of the Industrial Revolution with less developed and less polluted areas, especially along the coast, and these places gradually became viewed as destinations for spiritual fulfilment and relaxation (Page, 2015). In 1841 the entrepreneur Thomas Cook organized the first package tour - a one-day trip along a railway line between two towns just 12 miles apart - and subsequently began to organize tours all over Britain (and later to mainland Europe), taking advantage of the new networks of railways and steamships. The industry expanded throughout the $19^{\text {th }}$ and $20^{\text {th }}$ centuries, interrupted only by the two World Wars.

The current product offer is based on Britain's diverse and well-managed cultural heritage, varied scenery, excellent facilities for activity tourism, and good quality accommodation and catering. There is a robust domestic market in addition to the international market. In both cases, there has been an increase in consumers taking shorter holidays which allow them to accumulate experiences and memories rather than tangible souvenirs whilst on holiday (Mintel, 2016).

By 2000 Britain was one of the major source markets for tourism as well as one of the largest destinations. It ranked $5^{\text {th }}$ in the world for receipts from tourism and $6^{\text {th }}$ in terms of arrivals. In 2015 it was still in $5^{\text {th }}$ place for receipts but had slipped to $8^{\text {th }}$ place in arrivals (although it had sometimes seen slightly lower positions in the intervening decade). The principal markets are France, Germany and the USA. Over the 12-year period 2004-15 there was a 23\% increase in arrivals overall, although around the time of the global financial crisis in 2008 arrivals stagnated and then declined for a time. The peak of 30.7 million in 2007 was not surpassed until 2013; in the previous year the Olympics were held in Britain, with its attendant international profile. Other measures were taken to stimulate demand. Since then, numbers have climbed steadily to reach 34.4 million in 2015 (see Table 5.2).

By 2015 the service sector in Britain contributed around 78\% of GDP, and tourism is the fourth largest industry within that sector. It accounts for around 9\% of GDP ( $€ 127$ billion per annum) and $10 \%$ of employment, with around 3.1 million jobs (CMSC, 2015). According to figures cited by the UK's tourist board VisitBritain, the tourism multiplier is 2.8 , so that for every $£ 1,000$ generated in direct tourism spend, a further $£ 1,800$ is created elsewhere in the economy through the supply chain and consumer spend (Oxford Economics, 2013). 
Table 5.2: International Visitor Arrivals and Foreign Exchange Earnings - UK

\begin{tabular}{|l|c|c|}
\hline Year & Arrivals (million) & Receipts (US\$ million) \\
\hline 2000 & 25.2 & 19.4 \\
\hline 2001 & 22.8 & 16.3 \\
\hline 2002 & 24.2 & 17.6 \\
\hline 2003 & 24.7 & 22.8 \\
\hline 2004 & 27.8 & 28.2 \\
\hline 2005 & 28.0 & 30.7 \\
\hline 2006 & 30.6 & 33.7 \\
\hline 2007 & 30.7 & 38.6 \\
\hline 2008 & 30.1 & 36.0 \\
\hline 2009 & 28.2 & 30.0 \\
\hline 2010 & 28.3 & 32.4 \\
\hline 2011 & 29.3 & 35.1 \\
\hline 2012 & 29.3 & 36.6 \\
\hline 2013 & 31.1 & 41.0 \\
\hline 2014 & 32.6 & 46.5 \\
\hline 2015 & 34.4 & 45.5 \\
\hline
\end{tabular}

Source: UNWTO

\subsubsection{Crises Affecting the UK Tourism Industry}

The UK tourism industry is so large that one-off stress events appear to have little impact on tourism arrivals overall, as can be seen from Table 5.2: for instance, the London bomb attacks in July 2005 which killed 52 people appear to have caused a lower rate of increase that year, but by the following year the trend had continued upwards (albeit slowly, due to the global financial crisis). Longer-lasting stress events clearly do have an impact, as can be seen from the lower arrivals in 2001 compared to 2000; this was due to an outbreak of a highly contagious disease amongst farm animals (Foot and Mouth Disease), which is the only nationwide crisis to have occurred in the recent history of UK tourism to which known impacts can be attributed. Because of this, it will be discussed in some detail.

In February 2001 it was announced that the Foot and Mouth Disease (FMD) virus had been detected amongst agricultural livestock. A major cull of livestock was ordered. Harmful as the impacts on agriculture were, the impacts on the rural tourism industry were far more devastating. From the start of the crisis the public was advised to avoid leisure travel to and around the countryside, especially contact with farms. Use of off-road public rights-of-way was prohibited, many rural attractions were closed, and land owned by organisations such as the Forestry Commission and National Trust was closed to the public. Some of the worst affected areas were Britain's national parks. "In effect, the government's response ... was to place the entire British countryside under quarantine" (Sharpley and Craven, 2001). The media portrayed all of the British countryside as being 'closed for business' (Leslie and Black, 2005) and showed 
images of slaughtered animals being burned, thus creating downwards pressure on demand from domestic and international consumers.

The situation mainly affected leisure tourism in rural areas, while business tourism, VFR and visits to cities were unaffected: in fact, some commentators note that urban businesses benefited from the displaced leisure activity and spend. Within 2 months of the outbreak it was estimated that rural tourism revenues were reduced by $75 \%$ and that many small businesses such as guesthouses, country pubs and and craft producers faced bankruptcy (Financial Management, 2001). Domestically, 5.43 million consumers were found to have changed their travel plans as a result of the outbreak, and at least 120,000 took holidays abroad instead of in the UK (Leslie and Black, 2005). High profile events were cancelled, with a knock-on effect along the supply chain of accommodation and catering providers and rural retailing. Overall, it is estimated that spending in tourism was reduced by between $£ 2.7$ and $£ 3.2$ billion as a result of the epidemic (Blake et al, 2003).

While the impacts on individual businesses were major and in some cases devastating, especially since no financial compensation of the magnitude offered to farms was available, the effect on the rural tourism system generally was the most significant consequence. Up to that point, tourism had been perceived as an 'add on' to agriculture. Now, the government and other observers recognised that farmers had been increasingly diversifying not just into the traditional guesthouse offer but into a huge range of other activities, from craft-scale clothing manufacture through the production of small-scale beer and specialized high-value foods to the creation of adventure parks and festivals. It was found that by 2001, tourism contributed four times as much to the national economy as agriculture, and provided $7 \%$ of jobs as opposed to $1.5 \%$ in agriculture (CMSC, 2001).

There were regional differences in how the industry was affected. Parts of the north-west of England - especially the iconic Lake District National Park - were particularly severely hit, but a survey carried out in Scotland in the year after the outbreak revealed that only $15 \%$ of businesses ascribed the downturn in arrivals to FMD, while $26 \%$ cited the threat of terrorism (given that the $9 / 11$ attack happened later in 2001). Meanwhile, 7\% blamed the downturn on the poor weather that year (Leslie and Black, 2005).

It is noteworthy that an earlier outbreak of FMD, in 1967-68, had far less serious impacts. This was because rural tourism at that time was not as well developed and the government's response was less extreme, while the role of the media was said to be more 'passive', in other words giving more low-key accounts of what was happening rather than the sensationalised accounts of the 2001 crisis - especially by journalists reporting for foreign media outlets (Bater and Bowen, 2004).

Other crisis events which have affected UK tourism are:

- The political and social conflict affecting Northern Ireland from 1969-98 (known as 'the Troubles'). Although no estimate of the specific impact on tourism exists, the overall effect of the conflict on GDP in Northern Ireland is estimated at a reduction of 15-20\% 
compared to what the levels would have been if peace had prevailed throughout that period (Dorsett, 2013).

- An outbreak of 'swine flu' (H1N1 virus) in 2008-09, which is thought to have depressed arrivals and added to the effect of the global financial crisis (Page et al, 2012).

- Widespread flooding affecting the south-west of England in 2014 and the north-west in 2015-16. Dramatic pictures showed large areas under water, and some key elements of infrastructure were destroyed. In particular, the main railway line connecting Cornwall (in the south-west) to the rest of the country was rendered unusable during a 2014 storm. It is thought that extreme weather events such as the heavy rain over long periods which caused the floods are likely to become more common as global climate change intensifies.

\subsubsection{Recovery from Crises in UK Tourism}

This section will focus on responses to the 2001 FMD outbreak since this has been most thoroughly studied, with reflections on actions to address more localised crises also included.

Once the British government was aware of the scale of damage caused to rural tourism by FMD, its policies fell into three categories: encouraging visitors to return to the countryside; increasing accessibility to rural areas; and financial and other support for affected businesses.

Measures under the first type of policy included setting up a central telephone point to direct callers to appropriate sources of information, including a dedicated website (bearing in mind that social media did not exist at that point), and a public information campaign within the UK and overseas to reassure potential tourists that Britain was 'open to visitors'. However, a criticism of the government's action was that four times as much money ( $€ 14.2$ million as against $£ 3.8$ million) was devoted to overseas promotion rather than domestic promotion, whereas the rural tourism industry was almost completely reliant on the domestic market (Leslie and Black, 2005). Meanwhile, actions under the second and third policies were also criticised as inadequate. Businesses were offered a range of tax advantages and other financial help but these were mainly deferrals or loans rather than outright support, and there was further criticism that the measures were overly bureaucratic. Overall, "the support offered to rural tourism businesses contrasted starkly with the assistance and compensation provided to the agricultural sector which ... contributes significantly less to the national economy than tourism" (Sharpley and Craven, 2001, p. 534).

Key points thrown into relief by the FMD crisis were the disproportionately low profile of tourism at government level, the vulnerability of the rural economy, and the lack of cohesion amongst important tourism stakeholders. These issues led to institutional change. The existing Countryside Agency and Regional Tourist Boards were dismantled, with the functions of the latter centralized under the national tourist boards of VisitEngland, VisitScotland, VisitWales and Discover Northern Ireland (which focus on policy and promotion for domestic tourism) and VisitBritain, which promotes the whole of the UK in overseas markets. 
Many of the functions of the Countryside Agency such as the distribution of funding for environmental and tourism initiatives were subsumed into the Regional Development Agencies (RDAs), which were given an enhanced role in rural economic and social development, although some argued that rural affairs generally still received a low profile compared to urban affairs (Donaldson et al, 2006). This process was a largely successful attempt to ensure that regional policies were designed and implemented by policy-makers located within the regions concerned, rather than at national level.

The lack of cohesion between the public and private sector was partially addressed by creating the Tourism Alliance, a grouping of trade associations within UK tourism and hospitality, with the backing of the Department for Culture, Media and Sport (which includes tourism as part of its responsibilities) and the Confederation of British Industry. The Alliance represents the views of the private sector at government level and works with government on key issues. For instance, in 2016 and 2017 it produced reports analyzing the possible impacts on tourism of Britain's withdrawal from the EU in 2019 and identifying policies that the government should adopt to ensure the continued success of the sector afterwards.

A policy introduced in 2011 to try and stimulate growth in tourism after the 2008 global recession invested considerable sums in promoting Britain during and after the Olympics, aiming to increase arrivals by an additional 4 million after 2012 (Kennell and Chaperon, 2013). It appears that this effort has paid off, in that arrivals increased from 29.3 million in 2012 to 34.4 million in 2015.

To alleviate the 2014 and 2015-16 floods, the government put funding packages in place ( $€ 2$ million in 2014 to boost spending on overseas and domestic promotion and $£ 10$ million to support businesses recovery, $£ 2$ million in 2016 to repair infrastructure in the Lake District National Park and $£ 1$ million for a PR campaign to encourage British families to spend their holidays in the north of England). As part of the same effort, VisitEngland created a flood-risk toolkit designed to help individual businesses. The damage to the main railway line to Cornwall was repaired swiftly, in time for the main tourism season, having been prioritised by Government emergency spending.

As in other countries, the UK tourism sector has turned to the domestic market in times of weaker demand from overseas. According to a 2016 report, domestic tourism is in a healthy position, with 56 million holidays of at least one night taken within the UK by residents, and UKbased vacations no longer considered less desirable than overseas ones (Mintel, 2016).

\subsubsection{Critical Success Factors in Resilience of Tourism in the UK}

The strength of international tourism to the UK can be attributed to the following factors:

- The high number of repeat visits. In 2015 some $77 \%$ of arrivals were repeat visits; such people are likely to be more confident about visiting a country they already know.

- The high percentage of VFR and business tourism. London is the world's leading financial hub and the UK industry is highly globalized, which means that almost a 
quarter (24.4\%) of visits in 2016 were for business purposes. A further third of visits (30.75\%) were for VFR purposes, due partly to continuing close ties with the Republic of Ireland (representing around $8 \%$ of all visits), partly to the high number of people of British descent living in other parts of the world who wish to keep in touch with their families (e.g. Canada, Australia), and partly to the high number of recent immigrants from the EU and further afield who invite relations to visit them. Again, these markets are especially resilient.

- The diversity of the sector, from a large number of small businesses to major multinational chains.

- Strong recognition as a country brand. In 2016 the UK ranked $3^{\text {rd }}$ in the world (behind the USA and Germany) in recognition amongst 20,000 international respondents when scored across a range of attributes (VisitBritain, $n / d$ ).

- Subsequent to the FMD outbreak, there was far greater scrutiny of tourism by government than previously, with renewal of institutional structures and revisioning of the countryside: no longer was tourism seen as subsidiary to farming, but instead, farming began to be seen as the context of leisure opportunities - especially in areas such as national parks. In effect there has been a realignment of the rural economy across Britain, from a predominantly agricultural orientation to a service orientation in which tourism plays a major role (Cochrane, 2009).

\subsubsection{Weaknesses and Threats to Tourism in Britain}

As shown above, the UK's tourism industry is diverse and sophisticated, but the FMD crisis of 2001 revealed underlying weaknesses in the sector which partly account for the slow growth of international arrivals. During and in the immediate aftermath of the FMD crisis, there was widespread criticism of how the government had handled it. It was claimed that public sector responses were confused, ad hoc and too extreme; for instance the mass cull of livestock was said to be unnecessary as the actual number of livestock affected was small, and a vaccine against the disease was available. Meanwhile, the authorities did little to mitigate the impact on the nation's image and secondary effects of the piles of burning carcasses and pall of smoke which lay over swathes of the countryside. At a deeper level, the government was slow to recognise that the real crisis was in rural tourism rather than agriculture, and it compounded the problem by trying to distance itself from responsibility for the devastation which had befallen the rural tourism industry through its actions (Sharpley and Craven, 2001).

The Culture, Media and Sport Committee (CMSC) is one of a number of select committees appointed by Parliament to scrutinize the expenditure, administration and policies of government ministries - in this case the Department of Culture, Media and Sport (DCMS), which encompasses tourism as part of its brief. Since the Millennium the CMSC has produced three reports on the national tourism industry: in 2001, 2008 and 2015.

Based on these reports and other sources, the principal weaknesses identified in the UK tourism industry are: 
- The DCMS has a low profile within government compared to other ministries, while tourism has a low profile within the department, and the minister with responsibility for tourism does not always have this role reflected in their title. One consequence of this is the lack of strategic direction and leadership noted by the industry.

- Nearly half of all inbound tourists only visit London, which receives around 17 million tourists per year. Apart from a few other heavily visited cities (e.g. Stratford, Oxford, York) it remains a challenge to encourage visits to other parts of the country (Mintel, 2014).

- At regional level, the Local Enterprise Partnerships (LEP) which replaced the RDAs in 2012 are often too small to include a tourism specialist and as a result the profile of the industry is lower than it was under the RDAs. Some destinations have a good-quality DMO which provides good leadership, while others are weak. Until the 9 RDAs were abolished, VisitEngland had been able to work closely with them. Now, there are 39 LEPs and around 200 DMOs, making for weaker relationships. Partly as a result of this lack of expertise and focus, seaside destinations are often in decline, as their traditional markets grow older or find it cheaper and with more reliable weather to holiday abroad.

- Another weakness related to the fragmentation of leadership at regional level is that rural businesses in particular often struggle with marketing and management skills, and are uncertain who they should turn to for help (Briedenhann, 2008).

- The quality of welcome accorded to tourists at major entry points is often below visitor expectations, and the quality of service skills and quantity of people with appropriate skills is inadequate. This is partly because tourism is perceived as a low-skilled and poorly paid sector, offering only seasonal work in many places. There is concern that once Britain leaves the EU the problem will be exacerbated because around $20 \%$ of the workforce is from Central and East European EU member states.

- Businesses perceive a significant regulatory burden on their operations. For instance, taxation raises costs for overseas visitors and may deter some people from visiting. These taxes and fees include VAT, Air Passenger Duty, and visa costs. When visa prices were increased in 2005 by a considerable amount for visitors from many countries, the inbound tourism industry was taken by surprise as it had not been consulted. Visas to the UK are more expensive than to other European countries and the cost is seen by the industry as a major deterrent to prospective visitors.

- Obtaining tourist visas can be onerous, and entry arrangements at borders can be timeconsuming for non-EU citizens.

- The cost of hotel accommodation is not competitive in comparison with other countries.

- There is a need to increase skills and training within the sector. Currently around $20 \%$ of jobs are filled by migrants from elsewhere in the EU, and once the UK has left the EU it will be more difficult to fill these posts.

- Historically there has been a lack of policy attention to tourism from the government and civil service. While this was to some extent rectified after the FMD crisis in 2001, there remains a view that the private sector should take principal responsibility for developing the sector.

- Some key visitor attractions, such as national parks, have a haphazard approach to tourism provision. This is partly because of funding cuts affecting the public sector since 
2010, meaning that publicly funded bodies such as the national park authorities have had to cut costs and reduce staffing levels.

- There is some confusion over the role and responsibilities of VisitBritain and the tourist boards for the constituent parts of the UK (England, Scotland, Wales, Northern Ireland).

\subsubsection{Conclusion}

The FMD crisis of 2001 can be seen as the stressor event which broke into a poorly understood system of rural tourism and caused it to be reformed, with a greater emphasis on support through grants and promotion. This initially improved the enabling environment for businesses, although more recently the industry has criticised the lack of strategic direction; however public sector funding cuts since 2008 have affected all area of government activity and tourism is no exception.

Lessons learned were that poor risk management and lack of preparedness for an event of this type caused a risk to escalate into a significant crisis. Poor leadership was shown by the public authorities, also in the area of market understanding: the government was unaware of the importance of tourism to the rural economy.

Since the FMD crisis the sector has been reformed and the tourist boards overall provide a good level of promotional activity and business support such as training and networking, although not always with good attention to the needs of SMEs. UK tourism benefits from strong brand recognition and currently appears healthy, although in general business owners regard the uncertain consequences of the nation's forthcoming withdrawal from the EU with trepidation. 


\section{3. $\quad$ Case Study 3 - Thailand (Desk Study)}

\subsubsection{History and Development of Tourism in Thailand}

Thailand has been popular with tourists since early in the $20^{\text {th }}$ century, thanks to modernisation of the economy towards the end of the $19^{\text {th }}$ century. Measures included an 'open door' policy which encouraged foreign investment through tax holidays and other incentives to create the essential infrastructure of international standard hotels and tour programmes. Early on, the industry was given legitimacy amongst Thais by the royal family who not only travelled throughout Europe and thereby gained an understanding of the modern tourism industry, but also took seaside holidays in their own country, which gave momentum to the domestic tourism industry.

From around 1960 Thailand implemented export-oriented growth strategies and emphasised tourism in order boost foreign exchange reserves. The Tourist Organization of Thailand was established in 1960 and worked to develop the country's international image through introducing laws and campaigns to promote Thailand as a safe and secure place.

Thanks to strong policy measures by government tourism authorities in the 1970s and 80s, the offer soon diversified into attractions and activities based on Thailand's cultural and natural resources and on its urban assets, which provided good-quality shopping and entertainment opportunities. The Tourist Organization of Thailand was reformed as the Tourism Authority of Thailand (TAT) in 1979 and began a successful campaign of marketing the diversified tourism offer, starting with 'Visit Thailand Year' in 1980; international arrivals topped 2 million for the first time in that year. A further 'Visit Thailand' year was launched in 1987, against giving a significant boost to arrivals, with a $24 \%$ increase over the previous year (TAT online, $\mathrm{n} / \mathrm{d}$ ).

By the 1990s Thailand had emerged as a key player in the expanding tourism industry of Southeast Asia (Kontogeorgopolous et al, 2015). Tourist arrivals rapidly increased. In 1996 it received the second largest number of tourists in Southeast Asia (after Malaysia), with over 7 million international arrivals, and was the $3^{\text {rd }}$ largest tourism earner in Asia (after Hong Kong and China). By then, in geographical terms, tourism had spread from Bangkok to Phuket (in the south) and to Chiang Mai (in the north) and from these regional hubs into more places including Chiang Rai and the so-called 'Golden Triangle' in the north, and a variety of beach destinations in the south such as the Phi Phi islands, Khao Lak, and Pattaya.

In common with other Southeast Asian destinations, by 1990 Thailand was losing its reliance on the traditional source markets of Europe and North America as people from the emerging economies of East Asia started taking holidays abroad in greater numbers. By the mid-1990s tourists from Malaysia, Singapore, Japan, South Korea, China, Hong Kong, and Taiwan formed two-thirds of international arrivals. In 2016, 28\% of international arrivals were from China 9.3 million out of 33.2 million), and by 2020 it is expected that visitors from the Asia Pacific region will account for over $75 \%$ of international visitors. See Table 5.3 for international visitor arrivals and receipts from tourism. 
Table 5.3: International Visitor Arrivals and Foreign Exchange Earnings - Thailand

\begin{tabular}{|l|c|c|}
\hline Year & Arrivals (million) & Receipts (US\$ billion) \\
\hline 1995 & & 7.6 \\
\hline 1996 & 7.95 & 8.7 \\
\hline 1997 & 7.2 & 8.75 \\
\hline 1998 & 7.7 & 6.4 \\
\hline 1999 & 8.6 & 6.7 \\
\hline 2000 & 9.5 & 7.1 \\
\hline 2001 & 10.06 & 6.7 \\
\hline 2002 & 10.8 & 7.9 \\
\hline 2003 & 10 & 7.8 \\
\hline 2004 & 11.65 & 10.0 \\
\hline 2005 & 11.52 & 9.6 \\
\hline 2006 & 13.82 & 13.4 \\
\hline 2007 & 14.46 & 16.6 \\
\hline 2008 & 14.2 & 18.1 \\
\hline 2009 & 14.15 & 15.9 \\
\hline 2010 & 15.9 & 19.7 \\
\hline 2011 & 19.23 & 26.25 \\
\hline 2012 & 22.4 & 30.1 \\
\hline 2013 & 26.5 & 42.1 \\
\hline 2014 & 24.8 & 38.4 \\
\hline 2015 & 29.9 & 44.5 \\
\hline 2016 & 33.2 & 54.7 \\
\hline $50 u+5$. & & 2016 \\
\hline
\end{tabular}

Sources: Kontogeorgopolous, 1998; McDowall and Wang, 2009; Mintel, 2015; BMI, 2016; UNWTO online statistics

By 2000, Thailand had begun to forge closer links with neighbours such as Cambodia, Laos and Vietnam to develop a regional infrastructure leading to itineraries across the region. From 2001, the Mekong Tourism Development Project and the Greater Mekong Sub-Region (GMS) Tourism Strategy were significant: the 6 countries of Thailand, Cambodia, Laos, Vietnam, Myanmar and China (represented by Yunnan and Guangxi Provinces) agreed to cooperate to realize the potential of the GMS through creating an enabling policy environment and infrastructure linkages that would facilitate tourism as well as cross-border trade, investment, and other forms of economic cooperation (Sofield, 2008).

The project was funded by the governments of the countries concerned and by international aid agencies, in particular the Asian Development Bank. Tourism was designated as one of the flagship programmes because it was recognized as a major growth engine for socio-economic development and poverty alleviation and as a way to promote peace as well as conservation of natural and cultural heritage. Thailand played a central role in this scheme because its tourism industry and its economy were more mature than in the other countries. It acts as a hub for tourism and provides considerable stimulus for the industry throughout Southeast Asia. 
Thailand has continued to diversify its tourism offer in more recent years in response to the increasing sophistication of mature markets. Its products now include significant land and seabased adventure tourism and ecotourism, wellness tourism (including medical tourism and spas), cultural and heritage tourism (including cultural festivals, village-based tourism and three cultural World Heritage Sites), a strong MICE sector, and good-quality shopping and entertainment tourism, especially in Bangkok, which in 2012, 2013 and 2016 was the world's most-visited city (it received almost 22 million visitors in 2016). Sports tourism - especially golf - was given a higher profile when the Ministry of Tourism became the 'Ministry of Tourism and Sports' in 2002. The country's industry is well-placed to tap into 'creative' and experiential forms of tourism, in which tourists engage more strongly with local cultures and with their hosts. Wattanacharoensil and Schuckert (2015) point out that this links to the 'experience-seeking' society, i.e. the concept of enjoying experiences rather than passively consuming products and services.

By 2015 Thailand had reached $6^{\text {th }}$ place in the world rankings of receipts from international tourism with US\$ 44.6 billion generated in that year, making it the $2^{\text {nd }}$ largest tourism earner in Asia after China) and ranked $11^{\text {th }}$ in terms of international visitor arrivals, with 29.9 million arrivals (UNWTO, 2016).

A significant feature of the current tourism landscape in Thailand is domestic tourism, with local visitors accounting for an estimated $80 \%$ of all trips in 2012 and $45 \%$ of revenues (Suansri and Richards, 2013). There has been a deliberate attempt to target 'Generation Y'3, including marketing community-based tourism to young professionals as a way of fostering links between urban and rural communities (Richards, pers. comm., 6 April 2017). Diaspora tourism is a further factor, in that when Thais working abroad come home on holiday, they bring with them not only spending power from their overseas earnings but the expectations of leisure consumption learned in their new countries of residence (Scheyvens, 2007).

In 2017 the situation appeared stable. Tourism became Thailand's largest contributor of foreign exchange in 1982 and in now contributes around 20\% of GDP. A 2016 industry report on Thailand commented that many international hotel companies were expanding, and that the country remained attractive to investors and developers, with strong investment planned into the transport infrastructure and hotel sector into 2018 and beyond (Business Monitor International, 2016). There are forecast to be around 40 million international arrivals per year in 2020 .

\subsubsection{Crises Affecting Thai tourism}

Despite the apparent success of the tourism industry, Cohen (2014) points out that even by the 1980s it was obvious that rapid mass tourism development, poor planning, lack of enforcement of regulations, unscrupulous business practices and a failure of essential infrastructure to keep pace with development had led to a number of unwanted effects including overcrowding in some destinations; negative social impacts, including reduced social cohesion and economic inequality, abuse of human rights and displacement of people from their traditional lands in favour of resort

3 There are no precise dates for when this cohort starts or ends. Demographers and researchers typically use the early 1980s as starting birth years and the mid-1990s to early 2000s as ending birth years. 
development; and negative environmental impacts such as pollution, encroachment by tourism developments on national parks and other protected areas, biodiversity loss on golf courses due to over-use of pesticides, animal welfare abuses (especially concerning elephants), and other forms of environmental and ecological damage.

There has been negative publicity in particular regarding environmental damage. The coastline around some resorts became badly damaged due to mass marine tourism, removal of mangrove forests which used to form a barrier to coastal erosion, and dumping of garbage and untreated sewage into the sea. Regulation of tourism has been so weak in some places that in 2016 the Department of National Parks, Wildlife and Plants Conservation closed the island of Koh Tachai to tourists because its carrying capacity had been exceeded (BBC News, 2016). Similarly, the Phi Phi islands came under increasing environmental pressure because of the heavy increase in tourism numbers due to its location as the backdrop to the popular 2000 film 'The Beach'.

In addition to these general issues, several specific crises have affected Thai tourism in the last 15 years. These fall into the categories of political crises, economic crises, disease outbreaks and natural disasters.

- 2003: An outbreak of 'Severe Acute Respiratory Syndrome' (SARS) spread across East and Southeast Asia. Even though Thailand was barely affected by the disease itself, it was heavily affected by the decline in tourism generally across the region, with an overall reduction in visitor arrivals of around 7\% compared to the previous year.

- 2004/5: On 26 December 2004 a huge tsunami generated near the Indonesian island of Sumatra struck coasts around the Indian Ocean, killing an estimated 10,000 people in Thailand including around 3,750 foreigners. The principal places affected were popular tourism spots and this was the height of the 'winter' season, when sun-seeking Europeans were on holiday from the cold northern hemisphere winter. Total damages and losses were assessed at US\$2,198 million (1.4\% of GDP for that year) (Nidhiprabha, 2007). But although the disaster caused a drop in monthly arrival figures in the first few months of 2005, the damage to the infrastructure was not great and figures turned positive from June onwards. Growth of $1.4 \%$ was recorded over the year, and in 2006 figures rose by over $20 \%$.

- 2006: A military coup - the first non-constitutional change of government for 15 years - caused anxiety amongst key markets, but civil unrest was limited in extent and there was no significant impact on visitor arrivals overall.

- 2008: A political crisis included occupation and closure of the principal international airport for 8 days, leading to flight cancellations and knock-on effects such as cancellation of tours and hotel bookings. Even though this happened at the end of the year, arrivals showed a slight fall compared to 2007.

- 2008-9: The global financial crisis caused arrivals to decline slightly but they rebounded the following year. Domestic tourism was also affected, with a $10 \%$ fall in visitor spend in 2009 as people decided to save their money until the situation recovered (PwC, 2015). 
Along with Northeast Asia, Southeast Asia recovered more quickly from this crisis than other parts of the world, with particularly strong growth over 2010-11.

- 2010: Civil unrest included demonstrations leading to riots in Bangkok, resulting in 90 deaths and considerable damage to buildings. A State of Emergency was imposed in much of the country. This did little to depress tourism, however.

- 2011: Serious flooding due to exceptionally heavy rainfall killed nearly 1000 people and left millions homeless. Much of Bangkok's infrastructure was damaged, and the disaster was blamed by some on government not being prepared for the floods (Kanlayanasukho, 2014). Inaccurate reporting by international media may have contributed to the fall in demand: for instance, aeroplanes were shown surrounded by water, but without making it clear that the images were from the chief domestic airport, not the main international one. The governments of some source markets issued travel advisory warnings against non-essential travel to Thailand. Nevertheless, there was only a slight dip in arrivals during the worst of the flooding, and overall there was a $19.8 \%$ increase over the previous year.

- 2014: Two British tourists were murdered on Koh Tao, a popular backpacker destination.

- 2014: Another military coup resulted in the first drop in arrivals since 2009, with a fall of $7 \%$. Visitor numbers rebounded in 2015, with a $20.4 \%$ year-on-year increase (BMI, 2016).

- 2015: The bombing of the Erawan Shrine in central Bangkok resulted in the death of 6 Thais and 14 foreign nationals. A further 125 people (tourists and local worshippers) were injured. As a result, several source market governments issued travel advisories warning people to take extra care or avoid the country altogether. It is suspected that the bomb was placed by Islamist anti-government rebels from the 3 provinces in southern Thailand, where an insurgency of rebels operating on ethnic and religious grounds started in 1948 and has since been pursued with varying levels of intensity.

\subsubsection{Recovery from Crises in Thai Tourism}

Despite the various crises, international visitor arrivals to Thailand have generally been stable or declined by a relatively small amount year on year, and where there have been declines, arrivals have generally recovered the following year (as shown in Table 5.3 above). In years affected by negative events businesses have reacted in several ways, and because of the frequency and variety of the crises, individual businesses and the industry in general have become practised in their responses.

In the aftermath of crises such as the tsunami and floods, a priority is infrastructure reconstruction. For instance, in 2005-06 the government allocated a budget for tsunami relief and reconstruction of nearly US\$ 1.7 billion (Nidhiprabha, 2007). This consisted of funding for rebuilding damaged housing, roads, ports and water, sewerage and electricity systems, and included amounts set aside for business loans and compensation to people who had lost their livelihoods (principally fishing 
and tourism). No figures are available for the amount of money allocated for promotion and marketing.

One of the principal 'tried-and-tested' strategies is for businesses normally reliant on long-haul markets to turn instead to domestic and regional markets. The TAT started doing this as early as 2002/3, when arrivals from traditional Western markets to Southeast Asia weakened generally in the wake of the bombings of two nightclubs in Indonesia's principal holiday destination of Bali in October 2002. At that period the TAT initiated the 'Thai teow thai' campaign, which roughly translates as 'Thais go on holiday in Thailand' (Richards, pers. comm., 6 April 2017), while in 2008, the government worked with the private sector to organize a 'Thai Travel Fair' and reduce the prices of local flights and hotel accommodation, which increased the quantity and frequency of domestic travel (World Economic Forum, 2015).

In common with other Asian countries, Thailand also began to market itself much more strongly to neighbouring countries, taking advantage of economic growth rates across the region and the expanding middle class. Cultural factors have to be taken into account, however: Campiranon and Arcodia (2008) found that after the 2004 tsunami Asian tourists avoided affected destinations because they were afraid of ghosts, due to the large number of people killed in the disaster, while on the other hand Western volunteers flocked to the affected destinations to help with the rebuilding process and to support local businesses.

A study of hotels in Phuket by Campiranon and Scott (2014) and of responses to political crises in Thailand by Kanlayanasukho (2014) demonstrated that policies implemented by managers to recover from crises fell into 5 categories:

1. A crisis management plan already in place which could be quickly tailored to different types of crises, e.g. economic, political, or disease outbreaks, with customer safety prioritised through information and ensuring their relocation to a place of safety, including evacuation out of the country if necessary.

2. Thorough understanding of markets and targeting of appropriate markets and market segments in different circumstances. So, during the global financial crisis, hotels in Phuket concentrated more on markets closer to home than on long-haul visitors.

3. Issuing special discounted rates or adding value to their products, using phrases such as "affordable luxury" to encourage a continued flow of visitors.

4. Collaborating with other providers along the supply chain in order to reduce negative perceptions and create value-added packages.

5. Reducing staff costs by measures such as giving staff reduced hours or unpaid leave: managers reported that these measures were reasonably well supported by employees if the situation was clearly communicated to them.

At a micro-level, a study of tourism enterprises in Phuket by Biggs et al (2012) concluded that informal enterprises (i.e. small-scale, self-employed entrepreneurs) were more resilient than formal ones (i.e. licensed, taxation registered businesses) and recovered more quickly from the decline in visitors occasioned by the tsunami in 2004 and the financial crisis in 2009. 
Tourism is given strategic direction in Thailand by national tourism development plans. The plan covering the period 2012-16 emphasised improvement of the country's image so as to boost, increasing the confidence of tourists in Thailand as a safe, clean and welcoming place to visit (Pongponrat, pers. comm., 6 April 2017). Actions taken to implement these policies include a review of safety standards and regulations concerning transportation on lakes, rivers and the sea; becoming the first Asian country to join in with global efforts to clean up the oceans; and launching a 'Good Host' programme to maintain and improve standards of hospitality across the industry (TAT News online, $\mathrm{n} / \mathrm{d}$ ).

\subsubsection{Critical Success Factors in Resilience of Thai tourism}

Analysis of Thai tourism and its responses to crises suggest a number of critical success factors which have enabled the industry not only to survive but to recover and increase its key indicators (arrivals and earnings) rather quickly. These factors are as follows:

- Thailand's long history of tourism, its integration into other economic sectors in the country, and early efforts to diversify both product and market, meaning that any weakness in one area could be compensated by strengths in another.

- Strong government support for the industry (from macro to micro level), including providing access to finance and tax incentives. In 2010, for instance, the government gave tax incentives for companies hosting trade shows, while Thai residents were given an income tax reduction on travel-related expenditure (PwC, 2015).

- Effective campaigns by TAT to manage market perceptions in the aftermath of crises, for instance by setting up telephone hotlines to give up-to-date and accurate information and seeking favourable publicity through influential media with an international profile such as CNN and the BBC. TAT has used its official website to inform prospective visitors about the functioning of tourism services and infrastructure in the immediate aftermath of various crises including the 2004 tsunami, the political upheaval of 2010, and the floods of 2011. Beirman (2016) comments that the reliability of the information helped to build a solid reputation for TAT and for tourism in Thailand general, and was integral to recovery from these events.

- In the longer term, TAT has introduced new communications campaigns to create a positive image and attract more diverse and high-end markets, characterised as 'quality rather than quantity'. After the global financial crisis they launched an international campaign called "Amazing Thailand, Amazing Value", a claim confirmed by a survey which found Thailand was the best value destination in Asia-Pacific in 2009 (Campiranon and Scott, 2014), while after the 2014 military coup the campaign slogan was "Amazing Thailand, Grand Sale", with discounts for tourists in more than 15,000 shopping malls, department stores, and restaurants (PwC, 2015). In 2015 the campaign was "Discover Thainess", addressing the demand for experiential tourism. The organisation is adept at winning publicity in unlikely ways: for instance in 2015 a TATled team won first prize in the Sapporo 'Snow Sculpture' contest for its ice sculpture of a tuk-tuk (a small motorized passenger vehicle, ubiquitous in Southeast Asia). 
- The industry's ability to capitalise on market trends, in recent years especially experiential tourism, through good-quality services and facilities which allow people to 'achieve their dreams', and on the strong growth in medical tourism, through the provision of world-class facilities.

- Generally, there is a strong willingness to diversify, both in terms of the product and the market. TAT regularly reinforces awareness of Thailand's status as one of the top nations for various forms of tourism, e.g. one of the top shopping cities in 2014, and one of the 25 most popular countries to retire to in 2015 .

- Willingness to collaborate between different industry sectors, for instance hotels working together to promote a destination or airlines and hotels creating discounted packages.

- Willingness to re-position the industry in the light of trends; for instance the 2016 TAT promotional campaign incorporated sustainability and focussed on emphasising tourism quality, identifying new markets (in terms of geography and market segmentation) and 'rebalancing', i.e. ensuring that tourism benefits all economic sectors and social groups.

- A thriving economy, giving rise to strong demand from domestic tourists.

- Strong economic and collaborative linkages between different sectors making up the tourism industry.

- A significant informal sector of microenterprises where tourism is just one of the contributory income streams to the household economy, meaning that other sectors can take over when tourism is weak. In effect, such households operate as miniature diversified economies.

- Strong investment planned into the transport infrastructure and hotel sector into 2018 and beyond.

\subsubsection{Weaknesses and Threats to Thai Tourism}

Nevertheless, it remains to be seen whether these strengths will continue to overcome weaknesses identified by a range of commentators (including BMI, 2016; Ghaderi et al, 2015) which in the long run may undermine the country's success. These include:

- Further natural disasters such as flooding which could damage the infrastructure and deter visitors.

- Negative publicity concerning ecological damage and animal welfare, which could dampen demand in an era of increasing environmental concern.

- Further domestic unrest due to dissatisfaction with the government.

- Continuing bad publicity surrounding the defamation case against the BBC's Southeast Asia correspondent, who investigated frauds perpetrated on foreign retirees in Phuket. This is likely to undermine the important sector of retirees / second-home owners from abroad and damage Thailand's image.

- Weakness in the Chinese economy, which will depress demand from China.

- Lack of a 'learning culture' amongst private enterprises as identified by a range of commentators. 
- Ad hoc response to crises, rather than a comprehensive tourism crisis management plan

\subsubsection{Conclusion}

Lessons learned from Thailand's experience in countering crises which affect tourism are, in essence, that the government of Thailand through TAT has evidenced generally good leadership throughout the various issues which have affected the country since 2000 . The industry has proved remarkably robust despite the various crises, one reason being that none of the civil unrest has been directed at foreigners, and another being that the strength of positive social and cultural sentiment towards Thailand built up during many years of successful and peaceful tourism experiences stand the industry in good stead when a crisis event occurs.

It is also notable that TAT and the private sector show a clear ability to collaborate in order to present a unified message to key markets, to present reliable and reassuring information, and to adjust their product and promotional offers to attract market segments which are less sensitive to shocks. This demonstrates flexibility and a good ability to understand and harness market forces.

Nevertheless, there remains anxiety about the new king's role and about continuing societalpolitical unrest. If this creates an unsettling context for tourism, it is likely that potential visitors will start to look elsewhere for their tropical experiences - especially given growing opportunities in competitor countries. 


\subsection{Case Study 4 - Sri Lanka (Desk study)}

The structure of the Sri Lanka case study section is slightly different from the preceding ones because the principal crisis was very long-running and affected tourism more fundamentally and for longer than the crises in the other countries discussed. Accordingly, the principal two crises (both major ones) are integrated into the discussion of the history and development of tourism in Sri Lanka.

\subsubsection{History and Development of Tourism in Sri Lanka, including Crises}

Sri Lanka (named Ceylon until 1972) gained independence from Britain in 1948. By then, it was already a popular destination with Europeans, who continued to visit after independence. When modern mass tourism began to develop globally in the mid-1960s the government established The Ceylon Tourist Board (CTB) and the Ceylon Hotels Corporation in 1966 in order to foster the tourism sector in a systematic manner. Two years later, the Tourist Development Act of 1968 provided the CTB with the statutory authority to develop tourism on a planned and controlled basis.

Sri Lanka then experienced a decade and a half of rapid growth, with arrivals increasing at an average annual rate of over $20 \%$ and reaching 407,230 visitors in 1982 . The sector was predicted to make an increasing and significant contribution to foreign exchange earnings (De Bruin and Mithiyanandam, 2000). In 1983, however, tensions between the minority Tamil population and the majority Sinhalese broke out into communal violence, and civil conflict continued with varying degrees of intensity for the next 26 years. Given the sensitivity of international tourism to insecurity, the situation had a profoundly negative effect on arrivals. Decline throughout the 1980s was followed by a partial recovery during the 1990s as confidence grew that the fighting was confined to the north and north-east of the island, and there was substantial investment in hotels and other facilities such as golf courses. By 2000 visitor numbers were approaching their preconflict level, with 394,000 arrivals; this was forecast to double by 2010 (WTO, 2000; SLTB, 2006).

In 2002 a peace agreement further stimulated optimism and investment and arrivals surged to 566,000 in 2004. The industry became the fourth-largest source of foreign exchange, directly supporting around 50,000 jobs and 75,000 indirectly (USAID, 2004; World Bank, 2005). However, prospects for a full recovery were dashed when the south and west of the country were hit by the Indian Ocean tsunami of December 2004, killing an estimated 35,000 people (including 250 tourists) in Sri Lanka, making it the worst affected nation after Indonesia.

As far as markets are concerned, the focus during the early years of tourism development (as in other Asian countries) was on Europe, then recognised as the most lucrative. Since the late 1980s, though, European arrivals to Asia generally have declined in proportion to intraregional arrivals because of the growing strength of Asian economies, and while figures for Sri Lanka are hard to interpret because of the particular circumstances, it is evident that after the 2002 peace agreement arrivals from elsewhere in Asia were increasing in comparison to Europeans.

In 1992 Asia provided 29\% of all visitors to Sri Lanka, declining to $23 \%$ in 2000 but rising to $35 \%$ in 2004 and $41 \%$ in 2005 . However, the relative importance of Asian markets since then has barely 
changed, with Asia and the Middle East generating 43.4\% of arrivals in 2016. The principal regional market is India, which since early in the current century has provided around half of all Asian visitors, and many developments (for instance the golf courses) are designed to attract this segment.

By the time of the tsunami the length of stay of European tourists was declining. This partly reflects a general trend towards several shorter holidays throughout the year (facilitated by quicker journey times and lower air-fares) and partly reflects the decline in Sri Lanka's attractiveness to European markets in comparison to other countries (e.g. Thailand and Malaysia) because of a poorer quality offer and a failure to capitalise on evolving market trends, including less interest in straightforward beach tourism. These aspects are illustrated by visitors' average daily spend, which at US\$ 72.60 per person per day in 2004 was lower than in other comparable destinations (SLTB, 2006). This indicates that Sri Lanka was operating at the lower end of the mass long-haul market.

Recognition of these factors gave the stimulus for renewal in institutional structures as well as markets and products. There was increased focus on the emerging source markets of Russia and China and on the domestic market, as the middle-class expanded and people's aspirations were changing. Leisure movements within the country help to bolster the tourism economy and redistribute wealth from urban to rural areas, and also represent a channel for foreign currency to be redistributed through tourism: remittances from Sri Lankans working abroad contribute the largest source of foreign exchange earnings and about 10\% of GDP (Almeida, 2017), and many newly prosperous members of the middle-classes are former migrant workers who return home on vacation or to retire. The tourism industry recognised the importance of this market during the tsunami and conflict crises, and created cut-price packages to encourage them. Many hotels rely on spending by the domestic market, with weddings (particularly during the 'wedding season' in May and June) forming an important niche sector. By 2012 tourism was contributing 5.2\% of foreign exchange earnings (SLDTA, 2012).

Perhaps surprisingly, recovery from the tsunami in terms of tourism arrivals was fairly swift, with 549,000 visitors in 2005 , only slightly less than in the previous year (SLTB, 2006). This was partly due to the proactive stance of the industry, with its "Bounce Back Sri Lanka" campaign (funded by USAID) emphasising that most of the tourism infrastructure remained unharmed or had been quickly reconstructed. The authorities had in effect put into practice well-established crisis management techniques for communication and 'managing the message' (as reviewed by Scott and Laws, 2006). The emotional appeal to the sympathies of source market were successful in helping recovery; generally, as Mc Kercher and Pine (2006) point out, destinations recover quite swiftly from this kind of discrete, unpredictable event.

Had the tsunami been the only crisis incident the industry would most likely have continued to show strong growth, but in 2006 and 2007 the security situation deteriorated again because of the breakdown of peace negotiations and renewed terrorism activity. While still mainly contained in the north and north-east, occasional bomb attacks in Colombo and in tourist-frequented areas such as the international airport and the World Heritage Site of Galle, on the south coast, gave the conflict an island-wide spread. Tourists were not directly targeted by the rebels, but the continuing 
insecurity and high-profile military presence were deterrents to less resilient market segments. This was reflected in the decline in annual arrival figures, from 560,000 in 2006 to 448,000 in 2009 (Table 5.4).

Table 5.4: International Visitor Arrivals and Foreign Exchange Earnings - Sri Lanka

\begin{tabular}{|c|c|c|}
\hline Year & Tourist Arrivals ('000s) & $\begin{array}{c}\text { Foreign exchange earnings } \\
\text { (US\$ Million) }\end{array}$ \\
\hline 1995 & 403 & 225.4 \\
\hline 1996 & 302 & 173.0 \\
\hline 1997 & 366 & 216.7 \\
\hline 1998 & 381 & 230.5 \\
\hline 1999 & 436 & 274.9 \\
\hline 2000 & 400 & 252.8 \\
\hline 2001 & 337 & 211.1 \\
\hline 2002 & 393 & 253.0 \\
\hline 2003 & 501 & 340.0 \\
\hline 2004 & 566 & 416.8 \\
\hline 2005 & 549 & 362.3 \\
\hline 2006 & 560 & 410.3 \\
\hline 2007 & 494 & 384.4 \\
\hline 2008 & 438 & 319.5 \\
\hline 2009 & 448 & 349.3 \\
\hline 2010 & 654 & 575.9 \\
\hline 2011 & 856 & 838.9 \\
\hline 2012 & 1,006 & $1,038.3$ \\
\hline 2013 & 1,275 & $1,715.5$ \\
\hline 2014 & 1,527 & $2,431.1$ \\
\hline 2015 & 1,798 & $2,980.6$ \\
\hline 2016 & 2,051 & $3,518.5$ \\
\hline
\end{tabular}

Sources: Tourism growth trends, 1970-2016; SLTDA statistics and annual reports; UNWTO

Even apart from these obvious causes of sector under-performance and before the 2004 tsunami, it was acknowledged that tourism to Sri Lanka was not fulfilling its potential in terms of its contribution to foreign exchange earnings, numbers of tourists, and the diversity of market segments. Some of the reasons for this will be discussed below, after an overview of structural and market aspects are provided.

The principal government organisations concerned with tourism at the time of the 2004 tsunami were the Ministry of Tourism and the Sri Lanka Tourist Board (SLTB), which report to the Ministry. Other key institutions were the government-run Sri Lanka Institute of Tourism and Hotel Management, and private sector associations such as the Tourist Hotels Association of Sri Lanka, which works with the government on policy and with other trade sectors, and functions as a marketing organisation. Several of the larger destinations also had their own associations: for instance a stakeholder analysis at the west coast resort town of Hikkaduwa in 2007 found at least 
eight different sectoral associations, ranging from larger hotels to beach vendors (Calgaro and Cochrane, 2009).

The diversity of organisations was an indication of administrative and policy fragmentation, and it was admitted that there was a 'blurring of focus' (SLTB, 2007a). There was awareness that coordination was necessary, but uncertainty over the best vehicles to take collaborative energies forward. In a strong market such fractures would be little noticed, but in the continuing crisis situation the impression was of an industry turning in on itself and lacking the strategic vision which would give a framework for progress.

In 2009 the civil war ended with the defeat of the Tamil separatists. This created the opportunity for re-uniting the country and developing infrastructure such as an improved road and railway network, and for investment in tourism facilities by both domestic and international investors. The effect of the ending of the conflict is clearly demonstrated by the quadrupling of international arrivals in just 6 years, from 448,000 in 2009 to 1,798,000 in 2015 (Figure 5.2).

Figure 5.2: International Tourism Arrivals to Sri Lanka, 1995-2016

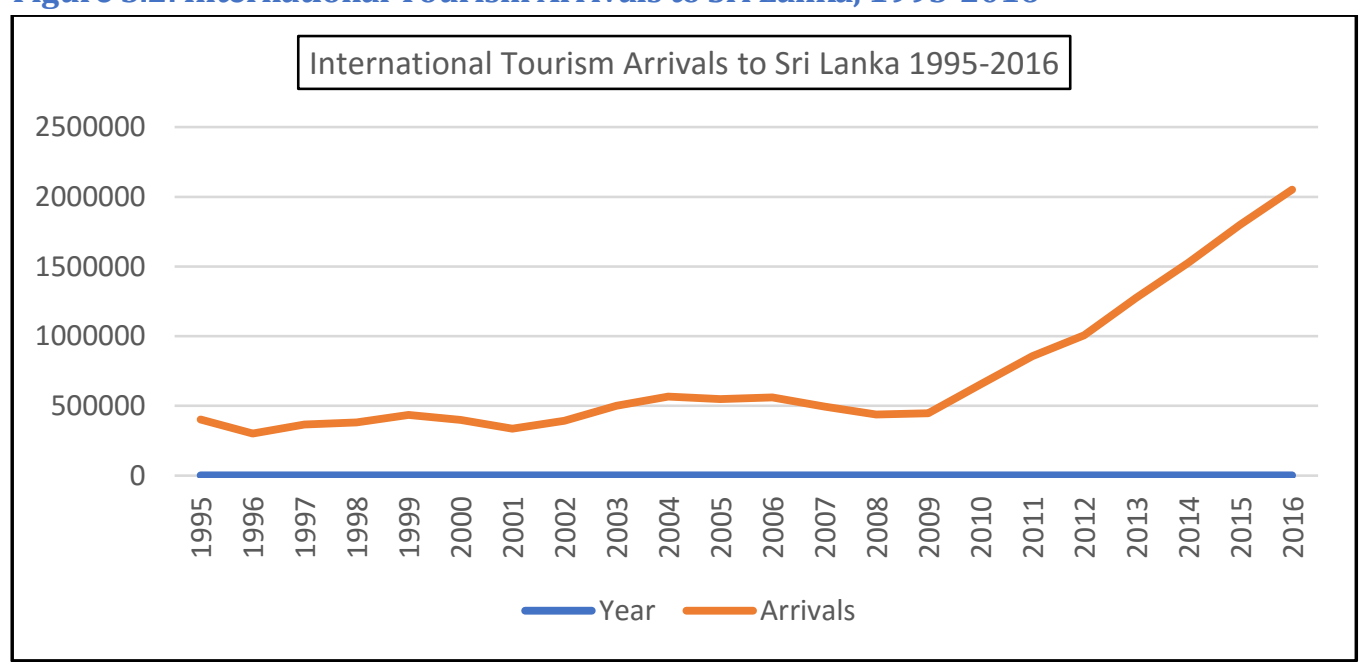

Sources: Tourism growth trends, 1970-2016; SLTDA statistics and annual reports; UNWTO

Since the end of the conflict and improvement of connections with the East Coast, there are more opportunities for both domestic and international visitors to travel to this area, much of which was off-limits during the war (Mann and Goel, 2014).

\subsubsection{Post Conflict Response: Recovery from Crises in Sri Lanka Tourism}

Shortly after the 2004 tsunami the government took several actions as a response to the disaster. It introduced The Disaster Management Act, the National Council for Disaster Management, and the Reconstruction and Development Agency. It also replaced several existing ministries by three new ones to deal with the crises, namely: the Ministry of Resettlement, the Ministry of Nation-Building and Estate Infrastructure Development, and the Ministry of Disaster Management and Human Rights. 
Specifically in terms of tourism, in 2005 the government introduced Tourism Act. No. 38 which reorganized the management of the tourism sector. It came into effect in 2007 with four organizations, namely: the Sri Lanka Tourism Development Authority (SLTDA); The Sri Lanka Tourism Promotions Bureau (SLTPB), which handles marketing and promotion of tourism; the Sri Lanka Institute of Tourism and Hotel Management to manage the human resources and Hotel Schools, and the Sri Lanka Convention Bureau. The government constituted also the Tourism Development Fund, made up from 33\% of Airport Tax (effectively a departure tax) and 1\% of the turnover of all establishments registered with Sri Lanka Tourist Board (Buultgens et al, 2016).

Putting these new structures in place meant that immediately after the end of the conflict in 2009, tourism in Sri Lanka was well placed to build on its recovery. International arrivals recorded a compound annual growth rate of almost 20\% between 2009 and 2016 and a compound annual growth rate of about $31 \%$ in foreign exchange earnings over the same period, while in terms of direct employment, jobs in tourism have almost tripled from 52,071 in 2009 to 146,115 in 2016 (SLTDA, 2012; Bhandari and Goel, 2017).

In 2010 the government announced a development policy framework -Vision for the Future which included a focus on sustainable development and diversification of the tourism sector, with the stated aim of providing benefits to all segments of society. As part of this, the six-year Tourism Development Strategy (2011-2016) outlined as its main strategic targets the diversification of the tourism offer, focusing on new markets, development of the infrastructure, improving services and human resources, promoting domestic tourism, enhancing industry professionalism, and conserving the environment. Although the hoped-for increase in jobs to 500,000 by 2016 was not borne out, in terms of tourism earnings the official figure released by SLTDA for 2016 was US\$ 3,518.5 million., much higher than the amount of US\$2,750 million. targeted in the strategy (SLTDA, 2012).

In order to regulate future tourism development projects, the government announced 45 tourism zones, including locations in the northeast of the country. Each zone had a specific theme for marketing purposes. These zones were intended to attract foreign investors in the high-end market including hotels as well as recreational and sport establishments, shopping centers and light aircraft services (Buultgens et al, 2016). In order to attract more investors in tourism, the government offered tax incentives on project investments exceeding US\$500,000. It also announced a Unit for National Investment in Tourism, the 'One Stop Unit (OSU), as a centralized contact point for investors seeking information on the tourism industry, including help with all formalities. Further efforts to attract investors and enhance economic development after 2009 included modernising the infrastructure in the island, including roads, railways, ports and air transportation. In addition, improvements in power and telecom sectors are also underway (Bhandari and Goel, 2017). 
The government also launched a PR initiative in 2011 to promote domestic tourism, with one attraction or festival announced each month of the year. A declaration by the President emphasized freedom of travel in a peaceful country. School Travel Clubs were established in order to motivate students to appreciate the cultural and natural heritage of their own country through travel. Another campaign to acquaint domestic tourists with their country was themed 'Lovingly Sri Lanka'. This programme focused on lesser known attractions and worked partly through video clips on social media and television. Meanwhile, several religious destinations are being targeted for development of domestic tourism in order to benefit the local communities in these areas. To keep accommodation affordable for domestic travellers the government has worked on upgrading some bungalows and guest-houses and encouraged the expansion of homestays (Ministry of Economic Development, 2011). The outcome of these activities has been increased spending by domestic tourists: Mann and Goel (2014) showed that domestic travel spending accounted for $52.1 \%$ of the direct travel and tourism GDP in 2013.

The tourism promotional plan of 2016 targeted 2.2 million visitors, with an average daily expenditure per person of up to US\$ 200, and total tourism revenue for the year of US\$ 2.75 billion. To achieve those objectives the authorities proposed to appoint PR agencies for major source markets. Although the arrival figures were not quite achieved, with an actual total of 2.05 million visitors, receipts exceeded the expected revenue, at US\$3.518 billion (UNWTO, 2017). Improved online and digital marketing was implemented, including inviting bloggers to give first-hand publicity based on their experiences. Web-based booking and tour planning services were expanded, while traditional tools such as familiarization tours and participation in travel fairs continued.

\subsubsection{Critical Success Factors in Resilience of Sri Lanka Tourism}

Sri Lanka is extremely rich in natural, cultural and heritage based resources. As explained above, Sri Lanka's tourism sector suffered severely during the war which lasted for almost three decades, while the natural disaster of 2004, fragmentation of responsibilities and the changes of policies in the country also contributed to the problems. While recovery after the tsunami was swift, further growth was hindered by continuing fighting. After the end of the war, however, tourism in Sri Lanka bounced back quickly to become a leading source of foreign exchange. Several factors have helped Sri Lanka tourism to recover and grow fast after the war:

- The Government is showing good leadership through its strong commitment to supporting tourism, and the peaceful and optimistic environment since the end of the conflict in 2009 has contributed to the quick recovery of tourism to become one of Sri Lanka's fastest growing economic sectors. The rapid rise in tourist arrivals after the conflict was due to implementation of a number of policies and promotional strategies, including launching of the Tourism Development Strategy 2011-2016 by the Ministry of Economic Development. 
- The industry gained strength as a result of the institutional and policy changes made by the government after the tsunami disaster, by which the tourism sector was restructured and its governance improved. The main change was the implementation of Tourism Act. No. 38 and the establishment of four organizations to manage the sector in more efficient way.

- The Government and other tourism stakeholders gained experience in marketing Sri Lanka as a safe destination during the conflict years, while after the end of the conflict marketing campaigns were more vigorous and effective.

- Diversifying the tourism product was a positive change in policy as tourism in Sri Lanka was marketed for so long as a traditional model of beach tourism. The country has an enormous amount of cultural and natural heritage-based resources including seven World Heritage Sites, temples of Buddhist heritage, national parks and other attractive natural areas. Further investment in these attractions should enable the country to increase its share in the international tourism market.

- Adoption of an integrated approach to tourism by establishing a close relationship between the government and other stakeholders is helping in the development of the sector.

- The post-war tourism boom has stimulated new investments, with some foreign hotel chains, such as Shangri-La Asia Ltd., Movenpick and Sheraton entering the country. This stimulates development by providing rooms to meet the demand, creating more jobs, maintaining a high standard of services and being part of the international marketing of high-end tourism.

- The recent improvements to roads, railways, airport and sea-ports have improved access to various attractions, enhanced connectivity within the country and facilitated development of new destinations in the north and east.

- The recent opening of East Coast areas for investments will encourage investors to open new establishments in these untapped east coast beaches.

- Sri Lanka can gradually become a more attractive MICE destination with the expansion of high-end accommodation, availability of conference halls and good transport connections (Bhandari and Goel, 2017).

- Sri Lanka's rich natural resources enable entrepreneurs to develop more types of special interest tourism such as nature-based tourism, geo-tourism, health and wellness tourism and new itineraries. Traditionally the most popular destinations were Colombo, the Southwest coast, the Cultural Triangle and the hill country. Tour operators have now begun diversifying itineraries to include cruise tourism, diving tourism and Ramayana trails.

- Europeans contribute to the bulk of demand between November and February during the northern hemisphere winter. Sri Lanka's proximity to India and China has resulted in sustained growth of arrivals from these countries, both of which have large populations with increasing middle-classes and an expanding wealth base. Other source markets of importance are Japan, the Maldives and the Middle East (Bhandari and Goel, 2017).

- The informal sector is also a developing and competing factor to formal accommodation, especially budget hotels, small guest-houses and home-stays, which attract FIT and backpacker travellers. 
- Sri Lanka enjoys a strategic location in the Indian Ocean on the major air and sea routes between West and East. This important location is an advantage to the country's positioning as a global logistics hub as well as tourism destination.

\subsubsection{Weaknesses and Threats to Sri Lanka Tourism}

Although the tourism industry has been successful since the end of the conflict in 2009, there are a number of weaknesses in the industry which can be summarized as follows:

- Sri Lanka lost a good number of its trained staff in tourism industry during the conflict period, mainly for better salaries offered in the Maldives, India and the Middle East, and during the current rapid expansion of the industry there is a shortage of qualified labour. To overcome the shortage, the tourism authorities are opening training centers in the principal towns and encouraging the private sector to have vocational training courses to overcome the shortage.

- Some of the very large tourism development projects may have social and environmental impacts at the time of their construction, and consequential impacts in the years after.

- The informal sector should not be marginalized but developed as it provides work and entrepreneurial opportunities, benefits the local community, and contributes to the diversification of the economy.

- Social and political problems related to the past conflict may revive if a long-lasting social solution built on equality between various sectors of society is not found. To address this, there should be more community involvement in tourism and solutions to local economic, social and environmental issues related to their tourism-affected areas.

\subsubsection{Conclusion}

It is apparent that the 2004 tsunami disaster in Sri Lanka acted as the shock event in the Sri Lanka tourism system which triggered several changes in tourism policy (Cochrane, 2009). These changes showed their positive results five years later when the country's conflict was over, since when the sector has enjoyed a rapid recovery. The government and other stakeholders have succeeded in marketing the country as a peaceful destination, hence attracting larger number of International tourists to double the number of international arrivals in less than three years.

Having said that, the social and economic impacts of the conflict will still be felt for some years to come, including the disparity in socio-economic welfare between the areas formerly held by the rebels, in the North-east of the country, and the wealthier southern parts. The state is the key player in social healing as well as economic development, and recognises that the tourism sector can play a vital role in promoting peace and harmony, increasing socio-economic inclusion, addressing reconciliation, generating employment, and accelerating economic growth in order to uplift the living standards of all Sri Lankans (Welgamage, 2015). 
UNWTO studies indicate that international tourist arrivals worldwide will reach 1.8 billion by 2030 . Asia and the Pacific in 2015 registered an above-average growth of 6\%, appreciably higher than in 2014 (5\%) which accounted for an additional 15 million visitors to the region (UNWTO/GTERC, 2016). These figures indicate that tourism in Sri Lanka has good potential to continue growing in the coming years if it can overcome the challenges of shortage of qualified labour, the lack of involvement of local communities, poor environmental management, and lack of diversification. 


\section{POLICY RECOMMENDATIONS}

\subsection{Introduction}

This section broadly follows the structure of Faulkner's 2001 Disaster Management Framework. It covers the different types of crisis and disaster affecting tourism systems in countries or destinations generally and emergencies affecting individual businesses. The aspects covered are institutional arrangements, crisis planning and responses, fiscal and legislative measures, and market responses. Recommendations will cover both public sector and private sector and are informed by the experiences of the eight countries studied in depth for this project as well as others.

The aim throughout is to support governments and private enterprises in creating resilient tourism systems which are able to withstand and recover from crises and disasters, whether due to anthropogenic or natural causes.

Consideration is given to dealing with anxiety aroused towards visiting Islamic countries or cultures due to the Islamaphobia.

To a large extent the recommendations made here are standard responses evidenced by the tourism and hospitality industry worldwide, but there are elements of risk and crisis management in Islamic states which differ from standard international practice because the challenges they face are exacerbated by socio-political upheavals currently taking place in the Islamic world, and by the response to these in source markets (especially Western ones). The recommendations do not constitute specific advice to individual governments or businesses, but cover the principal known and evidenced methods of risk and crisis management, which can be adapted to country-specific and sector-specific circumstances.

Section 6.2 gives the overall conclusions to the eight case study countries studied, while Section 6.3 builds on that by covering strategies and actions to be taken by government bodies such as departments and directorates-general of tourism, NTOs, and higher-level public-private sector organisations such as DMOs or local enterprise partnerships. Section 6.4 recommends actions to be taken by private enterprises.

\subsection{Conclusions from the Case Studies}

There are some similarities between the responses of the different case study countries to the crises they have experienced in their tourism sectors. An outline of the key responses is given below, grouped under the headings of risk and pre-crisis management, market responses, destination responses, and critical success factors. 


\subsubsection{Risk and Pre-crisis Management}

- Establishing a tourism-specific crisis management plan (by the tourism authorities) which integrates with the national-level disaster preparedness planning.

- Ensuring enterprise-specific risk awareness and crisis management planning (by individual businesses).

- Establishing good relations with media and travel trade representatives in order to ensure good support in the event of a crisis.

- Good communications and relations between stakeholders, e.g. horizontal communications between industry members and vertical communications between government and industry.

\subsubsection{Market-oriented Responses}

- Setting up a centralised hotline in the immediate aftermath of a crisis to answer media/ travel trade / individual tourist enquiries. The responses and messages given via the hotline must be consistent and truthful, since attempts to gloss over the truth or twist the facts will be quickly uncovered by journalists and individual tourists.

- Familiarisation trips for journalists, bloggers and tour operators.

- Immediate refunds for people who wish not to visit the country in the light of the crisis; offers of price reductions (for potential travellers) or accommodation upgrades (for people already booked).

- Building the destination's image through sponsorship; seeking and promoting 'good news' or unusual stories; co-creation of destination image through visitor contributions, especially through social media; funding bloggers to write about the country; engaging PR agencies.

- Market diversification, especially appealing to less sensitive markets, for instance regional markets which are more likely to understand the situation better, and/or other Islamic countries by crisis-afflicted Islamic countries.

- Appeals to the resident population to holiday in-country.

- Increased budget for marketing, sometimes linked to a 'Visit [name of country] Year' or a specific theme.

- In the mid to longer term, a thorough understanding of market trends helps to ensure a speedier and more appropriate response to crisis.

\subsubsection{Destination Responses}

- Introduction of crisis or disaster management plans and action plans (if this was not already in place), both at national level and local level and by the public sector and individual businesses.

- Tax holidays or subsidies, reduction in costs such as landing fees or visa fees, government grants to tourism businesses. 
- Direct funding by government and development agencies for rapidly re-building or upgrading infrastructure in the short-term, and for capacity-building in the medium to longer term.

- Product diversification, which can be integrated with market diversification to reduce reliance on a narrow range of products and services.

- Improved security on the ground and on flights (both visible to travellers and behind the scenes).

- Loosening of visa regulations or reduction in cost.

- Close collaboration by government authorities with other stakeholders.

- Good communication between the tourism industry and local community to ensure their support for tourism.

\subsubsection{Critical Success Factors}

- Where countries (or destinations) already have a robust tourism industry with strong underlying USPs, good recognition as a brand, and good customer loyalty (e.g. a high level of repeat visitors and warm links between visitors and local people), it is more likely that recovery from crisis will be swift. In some cases tourists who feel a personal connection with a country will donate money for its recovery (especially in the case of a natural disaster), and make a point of visiting in order to support the industry.

- The most successful recovery has been evidenced where there is strong government commitment to the industry as well as leadership in terms of strategy, policy, and understanding of market trends.

- Recovery has also been helped where there is clear evidence of public and private sectors working together and supported by the general public.

- Deregulation of over-bureaucratic procedures and introducing incentives for encouraging foreign investment.

- Looking to the longer term, some governments have introduced training programmes to build human resource capacity generally across the sector.

\subsection{Public and Third Sector Responses and Resilience}

In any tourism system, it is only the public sector which has the necessary resources, long-term view and balanced approach towards all stakeholders to provide the strong leadership which is essential for success of the tourism industry on a sustainable basis, and the creation and distribution of benefits for as many stakeholders as possible. It is also only the public sector which can create the enabling environment for tourism in the first place, particularly through its approach to legislation and taxation. For example, it was seen in the Indonesia case study that the Indonesian government created the foundations for the rapid growth in international tourism during the 1980s and 1990s by deregulating the sector, including removing barriers to foreign investment and reducing its formerly heavy-handed approach to tourism enterprise licensing. Furthermore, in 2017 the government of The Gambia was able quickly to lower taxes on fuel and energy supplies in order to reduce the cost burden for hotels affected by the loss of business due to the political crisis 
early in the year, during the peak tourism season. On the other hand, the South African government has received criticism from the private sector for imposing measures which stifle tourism growth, in particular the recent introduction of onerous visa requirements for visitors from important source markets.

At all stages of the tourism system cycle or the crisis management plan, there may be inputs from donor agencies or large NGOs, especially international NGOs. A wide range of agencies supported countries affected by the Indian Ocean tsunami in 2004; for instance the Stockholm Environment Institute funded a comparative study of tourism resilience in Thailand and Sri Lanka (Calgaro and Cochrane, 2009), and in 2014 the US Agency for International Development funded a crisis management and communications plan for Aqaba, in Jordan. This focused on the ' 4 R's' of effective tourism crisis management: Reduction, Readiness, Response, Recovery. These echo the six phases of tourism crisis planning as previously discussed, i.e. Pre-crisis; Prodromal; Emergency; Intermediate recovery; Mid-term and Long-term recovery; and Resolution. These aspects will be covered below.

\subsubsection{Pre-Crisis Contingency Planning}

In the first place, the lead government agency for tourism must work closely with other government departments to ensure that policies and action plans for disaster management include tourism as a key part of the Disaster Risk Reduction (DRR) or Disaster Risk Management (DRM) strategy. As pointed out in Section 2, the UNWTO recommends that tourism crisis management systems should be fully integrated within national and local DRR and DRM strategies at national and local level.

Essential steps at this stage are:

- Recognition of the potential risks to the tourism industry overall and to individual businesses.

- Identification of the particular threats most likely to occur, depending on the prevailing political and geographic characteristics: for instance, is the country in a zone prone to earthquakes? Are there separatist movements which may mount terror attacks targeting tourists? Different crisis management plans will need to be prepared for different scenarios.

- Establishing a tourism crisis recovery task force or crisis unit, with clearly designated roles and responsibilities. This unit is likely to have representatives from different government agencies (especially security and foreign offices). For example, the Tourism Authority of Thailand, which is highly experienced at dealing with different types of crisis, has a Tourism Intelligence Unit and Crisis Management Center. There should be frequent reviews of the roles and frequent meetings to discuss the plan.

- Designation of a location or institution which will become the Crisis HQ in the event of an emergency incident.

- Thorough and up-to-date market research to understand the reaction of different markets and categories to different types of crisis event, and to identify emerging trends and markets so that in the event of a crisis, appropriate markets can be quickly targeted. 
- Maintaining outline intelligence on how many tourists are in the principal destinations at any time, depending on the season. This will help with planning in the event of emergency evacuation procedures becoming necessary.

- Maintaining an up-to-date list of consular officials attached to each Embassy or High Commission who can be contacted in the event of a crisis incident affecting nationals of their country.

- Maintaining an up-to-date list of key contacts (email addresses, phone numbers) of businesses, trade associations and DMOs, so that close contact can be maintained in the case of an emergency.

- Maintenance of good relations with the media, especially news agency reporters, prominent travel writers or travel media editors in key source markets. This means that in the event of a crisis, press coverage is likely to be more favourable.

- Establishing clear channels of communication for tourists to access at any time: for instance, Thailand has two easy-to-remember phone numbers for dedicated 24-hour call centres staffed by English-speaking personnel: there is a Tourist Police hotline number to assist victims of crime or accidents is on 1155, while a 'Helpline' on 1111 was established in 2015 for non-emergency complaints.

These actions take place during the 'Conservation' phase of the resilience cycle (as explained in Section 1.3) and will help to build up a resilient tourism system with sufficient human and social capital to ensure strong linkages between stakeholders.

\subsubsection{Prodromal Phase: Warning Signs of the Crisis}

In some cases there may be no warning of an impending crisis, such as in the case of a natural disaster, while in others the signs may be evident some time in advance, such as with a disease outbreak, a deteriorating economic situation or the waning popularity of a government. It is relatively straightforward to plan emergency procedures for events in the former category - even though the exact location affected by the disaster will generally be unknown - but it is sometimes challenging for government officials to prepare for crises of the latter nature, especially if their careers are linked to the prevailing government of the day.

Nevertheless, there is a good deal that can be done to ensure that measures are prepared for use in a crisis. The principal actions are:

- Preparation of draft press releases for use in crisis situations. Usefully, the UNWTO's 2011 'Toolbox for Crisis Communications' includes 17 templates for press releases for a variety of emergency situations, including volcanic eruptions, major rail accidents, terrorist attacks, and outbreaks of infectious disease. All government NTOs which are members of UNWTO will have free access to this report and should ensure its availability to key personnel, especially those tasked with crisis management.

- Those responsible for communications during a crisis should ensure that the relevant UNWTO templates are adapted to the country or destination and pre-prepared (as far as possible) for release in the event of a fully developed crisis. 
- The Crisis HQ identified in the Pre-crisis phase should be readied and, if the crisis is clearly looming, additional staff should be deployed and briefed on what actions to take and messages to present.

\subsubsection{Emergency Phase: Protective Actions}

This phase represents the 'Disturbance event' (or series of events) which destabilises existing systems. The effectiveness of the immediate response to crisis will depend on measures put in place during the pre-crisis and prodromal stages. Once a crisis has occurred and a full emergency situation has developed, the following steps must be taken:

- The top priority is the safety and welfare of all tourists, sector employees and residents in the affected destination. This should be ensured by providing medical and food assistance during or immediately after a natural disaster or other crisis to cope with any injuries and meet the subsistence needs of people affected.

- Emergency evacuation procedures should be put in place if necessary to take people to a place of safety (either in-country or back to their home countries). The lead government agency should work closely with airlines, inbound tour operators and ground agents on this.

- The Crisis HQ should become operational, with key announcements fronted by a designated spokesperson and hotlines staffed by fully briefed personnel. Messages must truthful. The Crisis HQ / call centre may need to answer enquiries from the media, tour operators and relatives of visitors caught up in the crisis. As explained above, the Nepal Tourism Board posted details of emergency phone numbers on its Facebook page on the day after the major earthquake in 2015 , which demonstrated that they were dealing proactively with the situation.

- The lead government agency should inform tourism businesses through their preprepared email / phone number listings of the 'hotline' to which enquiries by the media and general public should be directed.

- As soon as the safety of visitors and residents has been assured, the government should carry out an assessment of the most urgent infrastructural repairs needed to restore communications and transportation (by land/sea and electronically).

\subsubsection{Intermediate Recovery Phase}

Once people's safety has been assured, the primary essential actions during this phase are as follows:

- Emergency infrastructural repairs identified in the previous phase should be carried out.

- The lead government agency should work closely with businesses in the affected area to ascertain the extent of the physical damage.

- Depending on this assessment, the public and private sector should cooperate closely to ensure that the messages conveyed and actions taken are consistent with each other 
and with the government's own stance. For instance, there is no point in a hotel which is undamaged by the disruptive event continuing to promote itself to tourists if the surrounding area has essentially been destroyed. In other cases, destination stakeholders may be quickly able to repair the damage and continue to offer tourists a good experience.

- The lead government agency should design consistent, accurate messages for dissemination through all media channels. The effectiveness of messages in this phase will depend partly on the nature of the crisis and partly on the underlying resilience of the tourism system. As stated earlier, to a great extent this depends on actions and relationships built up during the pre-crisis or 'Conservation' phase.

- The government should review its taxation policy: are there incentives, subsidies, tax holidays or grant schemes which can quickly be legislated for to support the private sector in reducing its costs? This will allow businesses to reduce package prices and make special offers such as ' 3 weeks for the price of 2' or accommodation upgrades.

- Messages regarding changes to fiscal or other regulations can be most effectively disseminated through trade associations. For instance, the Tourism Business Council of South Africa is the chief intermediary between the Ministry of Tourism and South African Tourism and individual businesses.

\subsubsection{Recovery Phase - Mid-term}

In this phase the public sector should put in place more detailed responses to the crisis. Measures may include:

- Legislation to encourage overseas investment in building or upgrading tourism facilities, as in Sri Lanka after the end of the long-running civil conflict in 2009.

- Increased security in public places and behind the scenes both to try and prevent terrorist attacks and reassure the public that everything is being done to ensure their safety, as in the UK after the terrorist attack on concert-goers in Manchester in 2017.

- Thorough training of in-country security services tasked with responding to terrorism threats. For instance in the aftermath of the killing of 38 tourists on a Tunisian beach in 2015, a particularly damaging news report was that Tunisian security officers had wasted time in reaching the location after they were aware of the attack (The Telegraph, 2017).

- Financial support to businesses (for example low-cost loans) to help them repair damage and upgrade their facilities. 
- Individual businesses are rarely able to access up-to-date market research findings due to the expense, so governments can disseminate this information (generally a synopsis is sufficient) and/or run workshops to inform businesses about market developments. This will support the private sector in product diversification and help them design targeted promotional campaigns.

- Contracting professional PR agencies to repair reputational damage by creating positive stories about the destination or even establishing a government department with the remit to create and foster the country's brand. South Africa has taken both these actions: South African Tourism engaged a PR agency in 2014 especially to attract visitors from European markets, and there is a dedicated government office called 'Brand South Africa' which works to maintain a positive image of the country overseas (although as noted above, this campaign backfired due to the PR company concerned working simultaneously against the country's interests).

- During this phase and the next it may become clear that pre-existing systems had become inadequate to support the modern tourism industry. Thus, the UK government reorganised its institutional tourism support system after the 2001 outbreak of Foot and Mouth Disease once it recognised how badly the tourism sector had suffered.

The reorganisation of systems and emergence of new institutions which may take place during this phase is typical of the 'Exploitation' phase of the resilience cycle, when human, social and financial capital built up during previous phases of the cycle are exploited to create new systems. This is akin to the advice to 'Build Back Better' offered to the Council of Australian Tour Operators as part of their crisis management procedures (Beirman, 2016).

\subsubsection{Recovery Phase - Long-term}

Security measures to ensure the safety of tourists are a top imperative, as highlighted in the previous phases, but unless the international market and trade are convinced of their effectiveness, recovery will be slow. In addition to the measures already outlined, the following steps are recommended:

- The public sector agencies responsible for tourism must ensure that close contacts are created and maintained at government-to-government level and with the media, and at trade level and with targeted markets and segments. At government level, dialogue between the NTO and foreign affairs ministries of source country markets must be maintained in order to convey transparent information on the security situation.

- Contacts with the tourism trade and markets are more effectively managed through public-private sector partnerships. For instance, familiarization trips for journalists and tour operators can be funded by the government but organized by tour operators / ground handling agents, while the rapid 'word of mouth' effect of social media relies on the satisfactory experience provided by tourism business to individual tourists. Adding flights between the destination and new markets will also require strategic planning with the private sector. 
- Full and effective image rebuilding will include convincing source markets that Islamic countries can respond to demand by matching products to market segments. This may mean that domestic tourists, visitors from other Muslim countries, and less crisis sensitive or more adventurous segments from longer-established markets are prime targets to stimulate recovery and fill the gap left by more crisis-sensitive markets and segments.

- Longer-term infrastructural improvements should be implemented in order to provide firm foundations for renewal of the tourism product, for instance new highways or link roads to connect tourist destinations to entry points, new regional airports, and upgrading of sea-ports in order to accommodate cruise-ships.

This phase and the next are equivalent to the early and mid-term stages of the 'Conservation' phase of the resilience cycle, during which new institutions become established and new human capital formed, often through training and capacity-building.

\subsubsection{Resolution Phase}

This phase will run concurrently with the mid- and long-term recovery phases. Essentially it allows for assessment of measures taken to rebuild the tourism industry and modification of measures taken as appropriate. It is akin to the final stage in the normal six-stage planning cycle, which consists of:

- Assessing a situation (the situation review)

- Outlining different options and selecting the most practicable ones

- Detailed planning

- Implementation

- Review (through monitoring and evaluation)

- Adjusting the next phase of the plan based on the review.

All government departments will be aware of this planning cycle, and strategists within the lead tourism body will be able to apply it to their own situation.

The risk management phase can be strengthened by utilising the feedback from, and evaluating, the measures taken during previous crises, in particular in respect of product and market diversification. 


\subsection{Private Sector Responses and Resilience}

While governments need to provide the overall framework and leadership in any successful tourism system, individual tourism, hospitality and leisure enterprises are the primary interface with the customer and, as such, must have contingency plans in place for dealing with emergencies. The crisis management plan must be devised at a time when managers and other staff have time for reflecting on possible crises which can occur and how these can be dealt with (i.e. it should be worked on outside the peak season). In contrast to the public sector, individual enterprises must also plan for site-specific risks such as a fire on the premises or accidents affecting individual tourists. The phases of crisis risk planning by the private sector follow the same pattern as with the public sector: these are covered below.

\subsubsection{Pre-crisis Contingency Planning}

It is essential that future-proofing for possible risks becomes part of the organisational culture of the tourism enterprise. A crisis may be sudden, as in the case of a natural disaster such as an earthquake or tsunami, or it may develop much more slowly, as often with a political crisis. Core features of a business's ability to adapt in either circumstance are that:

- A senior staff member must be designated to lead on the plan and be responsible for updating it on a regular basis.

- Specific roles and responsibilities in responding to and managing a crisis must be allocated.

- Regular checks and training must take place to ensure that all staff are aware (a) of the types of crisis that might occur and (b) of their responsibilities in the event of each type of crisis.

- Good relations with local journalists should be maintained.

- Standards (in respect of, for example, environmental and food preparation practices) should be integrated and monitored.

- A spirit of shared community feeling should be created and maintained with past and potential customers; this builds up a store of emotional and social capital which can be drawn upon in the event of a crisis. Social media is an excellent way of operationalising this.

It is impossible to create a generic plan which will cover all crises in all countries, since the circumstances of each are very different. However, the lead government tourism agency will work with businesses and trade associations to prepare these plans, using a process of scenario-planning to assess the potential risks facing each country (or destination), prioritizing the risks based on how likely they are to eventuate, and deciding on strategies and actions to take if the risks turn into actual crises. 


\subsubsection{Prodromal Phase: Warning Signs of the Crisis}

Businesses should start to move their plan into the operational phase once the signs of a crisis start to appear. In the past this was not always possible because sudden, major events were usually unexpected. However, since the Millennium the world has become somewhat habituated to unforeseen major catastrophes such as the 9/11 terrorist attacks and the 2004 Indian Ocean tsunami and to a host of more minor ones, and nowadays it is imperative for businesses to be prepared for events of a similar magnitude.

From the events studied for this report, it is clear that in most cases there are warning signs of an impending crisis situation (for example financial or political crises such as the Global Economic Crisis of 2008-9, the current economic crisis in South Africa, and the presidential challenge in The Gambia in 2016-17) or at least sufficient precedents for the industry to be able to plan ahead (for example the suicide bombings in London in 2007, Paris in 2015, Brussels in 2016 and Manchester in 2017, and the terrorist lorry and van attacks in Nice in 2016 and Stockholm, London and Barcelona in 2017).

\subsubsection{Emergency Phase: Protective Actions}

As soon as a crisis begins to occur, managers or other people in authority need to assess whether and to what extent their business or destination is likely to be affected. This will depend to some extent on the type of business and its geographical proximity to the location of the incident. The three key stages of action during this phase are as follows:

- The first priority is to ensure the safety of any customers on-site or currently the responsibility of the business, for example guests in a hotel damaged by flooding, participants in a tour group stranded or unable to return to their hotel, or visitors caught up in a political crisis whose trip may no longer be viable. The needs of non-essential or vulnerable staff members (including older people and pregnant women) should also be taken into consideration; or staff may wish to return to their families to take care of them.

- Customers must be transferred as quickly as possible to a place of safety or even evacuated to their home country. In the meantime, they will appreciate being kept fully informed of the situation. It was noticeable that during the major failure of IT systems which affected British Airways in May 2017, resulting in flight cancellations, delays and lost luggage for around 75,000 passengers, a principal complaint was that there were no announcements and no staff on hand to advise people what was happening (The Guardian, 2017). Half a billion pounds were wiped off the company's share price in the aftermath of the crisis, and it is estimated that the incident will eventually cost BA around $£ 150$ million in compensation claims and lost business. 
- The next priority is to contact any customers that have booked holidays and advise them of the situation and its effects on the business. If the business is not directly affected, if staff can still get to work, and if the infrastructure, supply chain and other attractions are still operational, it may be possible to persuade people to continue with their holiday as planned - perhaps through offering a 'free' accommodation upgrade. If there is too much damage or if customers are too nervous to travel, they should immediately be offered a refund or an alternative holiday at a later stage.

- Being proactive in this way will reassure customers that the company is prioritising their needs (rather than its own profits) and make it more likely that people will re-book at a later stage - and that they will publicly praise the company's positive response. For instance, after the 2004 tsunami, UK-based mobile phone companies waived charges incurred by users in affected countries even if they were not directly involved in the disaster, as they recognised that individuals were calling home to reassure their friends and families. This created considerable goodwill for the companies concerned.

- After ensuring customer safety, managers should assess any infrastructural damage to the business (for example in the case of floods) and, as far as possible, carry out essential repairs and maintenance. Sometimes infrastructural damage may be too severe to repair quickly (e.g. if affected by severe flooding, cyclones, earthquakes or rioting) or it will be necessary to wait for insurance company loss adjusters to assess the damage before repairs can be effected.

- If the enterprise has to close, customers could be recommended to another company under the same ownership but in a different area which is unaffected by the crisis, or to another local hotel or tour operator - it is better for a competitor in the same region to gain the customers than to lose them altogether.

- Businesses should maintain a database of advance bookings so that people can be contacted quickly in the event of an emergency, bearing in mind that if customers live some distance away or in another country, the first they hear of the incident may via this contact. This is an opportunity establish a goodwill relationship with customers, as they will appreciate the early advice - and, as stated above, they can be given a choice of alternatives.

- The same applies to people who may be part-way through a holiday: a disaster or crisis may cause disruption to transportation or other services, and customers need to be informed in a straightforward way and reassured that everything possible is being done to ensure alternative arrangements or - if the crisis is severe - that arrangements are being made for their safe return home.

- It is essential that staff members making the phone calls are well informed and confident, as this will inspire confidence in the customer. 


\subsubsection{Intermediate Recovery Phase}

Once the immediate crisis is over, business owners and managers can focus on limiting the physical or reputational damage to their business. Key steps are to:

- Communicate and collaborate with other businesses locally, since they may be in the same situation. A coordinated response will be more effective in getting positive messages across than for businesses to work alone. In principle the local or national trade association, tourism board or DMO should by now be putting their own preprepared plan in place (as discussed in Section 6.2). The agency responsible is likely to be gathering facts and figures so that it can relay factual and consistent information to any local or national hotline, and will also be seeking 'good news' stories to feed to bloggers and other social media outlets.

- Reciprocally, the lead government agency should have up-to-date information on aspects such as the current state of the crisis, for example the extent of floods, which can be relayed by businesses to their customers. They should also have developed positive messages to reassure the public that even if the situation has not yet returned to normal, as soon as it does the destination will again be 'open for business'.

- Most members of the public are aware nowadays of the extent of 'fake news' on social media, and also that messages (whether true or false) can travel very fast, and therefore businesses need to circulate their own information. It is essential that these messages are honest: there is no point in trying to encourage visitors if their welfare, security or enjoyment will be impaired.

- Messages should be optimistic and focus on positive aspects of the location, for instance any attractions or facilities that are available or the stories of individual tourists who are enjoying a holiday in the destination post-crisis. Whatever difficulties business owners themselves are experiencing, they should not share these with customers. The only exception might be for customers who already know the business well and perhaps make personal enquiries as to the situation; they may be prepared to help in ways that new customers would not. For instance, after the 2004 tsunami guest-house owners in Sri Lanka reported being given direct financial assistance by former customers aware of the hardship experienced by local communities; the same happened after the Nepal earthquake of April 2015.

- In some cases, businesses may quickly be able to access new markets in order to ensure business viability and continued economic benefits to employees and the supply chain. For instance, after the 2004 tsunami, undamaged hotels in Sri Lanka and Thailand were able to provide facilities to the large number of aid workers and volunteers who arrived to help with recovery. 


\subsubsection{Recovery Phase - Mid-term}

- Once the needs of existing and pre-booked customers have been taken care of, businesses should turn to potential future customers, some of whom may have been considering a visit but are being deterred by sensationalist media coverage. Another category is people who may not have heard of the destination prior to the crisis event (or may not know much about it) but the media coverage has aroused their interest and created a desire to visit.

- Businesses should ensure that their website, Facebook page, other social media channels under their control and relations with external media are all regularly updated with messages about the situation and the recovery phase. Comments should be light and positive and should focus not only on the business in question but include other local businesses - this demonstrates that there is an active, cohesive and attractive destination which is still worth visiting.

- The heightened interest in the destination is a great opportunity for businesses and destinations to showcase themselves. It is well worth asking any existing customers who have had a good experience to post their own comments on Facebook, TripAdvisor, Instagram, etc., especially while they are actually in the destination - they will demonstrate through their photos and comments that they are enjoying a good experience despite recent events.

- Social media is also an excellent way of disseminating positive messages such as roads re-opening, volunteer help with re-building, or activities and festivals still taking place. It can also be a good idea to insert links to weather or travel websites. This can all help to build up a rapport with potential customers and respond to any concerns.

- If there is a local DMO or trade association, businesses should find out what \#hashtag is being used for the event or incident so that they can tag their tweets and ensure that they are part of the conversation.

- It is difficult for individual businesses - especially small ones - to win the attention of the mainstream media. It is more likely that the DMO, tourist board or trade association will have more success. However, if a business has sufficient skills and good contact with the media, it is worth issuing press releases to present positive information and key messages in a managed way. Local media in particular are generally keen to promote positive campaigns as a way of showing solidarity with the local community. Press releases should be honest and reassuring, and angles could include adapting the product offer to the situation (for instance a hotel could offer 'storm watching' breaks in the rainy season or winter).

- Forthcoming promotional activity should be reviewed: can any pre-booked advertising be cancelled if it is no longer appropriate? If it cannot be cancelled for contractual reasons, can the message at least be changed? 


\subsubsection{Recovery Phase - Long-term}

There may inevitably be a period when the business is closed, especially if there is structural damage or if the wider destination has experienced infrastructural damage, and even if the business has not actually closed down, visitor numbers may have declined considerably. This is the time to address the future impact of the situation on the business. Key aspects to cover are:

- A review of costs and pricing: can costs can be reduced, perhaps by switching the energy supplier to access a cheaper tariff? Cutting staff hours is preferable to laying people off entirely. With staff on a formal employment contract this can only be achieved within the terms of their contract or according to national labour legislation. Can prices be heavily discounted in order to attract people back? This tactic has been used by tour operators such as The Gambia Experience to draw visitors back to The Gambia after the brief crisis early in 2017.

- A review of the product offer: this may be the moment to put into operation plans for diversifying the product to take account of market trends. For instance, in Sri Lanka after the shock of the 2004 tsunami, some businesses took advantage of the initial decline in business and then the renewed interest to re-build and re-launch themselves: the Ranweli Resort is located on the coast and initially operated on a traditional 'sun, sea and sand' model, but during the late 1990s it was refurbished as an eco-friendly venture. After the 2004 tsunami its renewed identity came into its own as it devised new promotions based around environmentally friendly policies and wellness tourism. Also in Sri Lanka, the government launched a new beach festival at the coastal resort of Hikkaduwa after the tsunami to help revitalise the industry and extend the season further into the shoulder months.

- A review of target markets: are regional or domestic markets developing so that local tourists can take the place of foreign ones? In Indonesia, after the financial and political crisis of the late 1990s and the Bali bombings of 2002 caused a decline in Western and East Asian markets, many hotels and guesthouses targeted local consumers instead. In some cases, prices per person had to be lowered to allow for the different economic characteristics of domestic tourists, but profit margins overall could often be maintained by allowing more people to occupy each room, in keeping with cultural norms. More recently, Egypt has been targeting Middle Eastern markets more strongly in place of its prior focus on Western ones. One measure is to introduce a simplified evisa programme for visitors from Gulf Arab States (Yousef, 2017).

- Tourism operators should ensure a close working relationship with other businesses in the same geographical area or the same niche, especially through DMOs and through trade associations. It is much easier for governments to filter advice and information on market research, fiscal changes or support packages through these larger organisations than to individual enterprises, especially as the tourism landscape in most countries is dominated by SMEs (i.e. Small and Medium-Sized Enterprises). 


\subsubsection{Resolution Phase}

As with the resolution phase in public sector crisis management approaches, private enterprises should take time to review their actions for effectiveness and make any adjustments, consistent with the resources available to them. It is at this stage that true resilience will be built into the organisation in that they should by now have created good networks with other tourism stakeholders locally, nationally and (in the case of larger enterprises) internationally, and in that they will be well aware of how to respond to changing market trends and match their products to available market segments.

- If a business does not already have a crisis management plan in place, now is the time to create one - especially building on recent experience. It is advisable to collaborate with other local businesses, trade associations or the DMO to work through the stages of this collectively, and it may be possible to access post-crisis funding from governments or donor agencies to support the process. This is a good way of creating strong networks as well as using resources efficiently. ${ }^{4}$

\subsection{Concluding Remarks}

The principal tried-and-tested strategies and actions for rebuilding a country or destination's tourism image after a crisis have been highlighted in this section. Their efficacy has been proven in numerous different situations. In particular, a good contingency plan, constantly updated, is vital. Accurate, timely and responsive information from a reputable source such as the NTO may act as a counterweight to the sensationalist reporting which can damage domestic and international tourism markets. Another lesson is the vital need for the ongoing representation of tourism within national-level crisis management strategies, as it is a vital and embedded component of both advanced and emerging economies.

However, recovery efforts will only be effective if the disaster or crisis is a one-off or rare occurrence. If the underlying cause of the disruptive event remains unresolved, such as with longrunning political and social tensions, little can be done to repair a country's image and persuade tourists to return. Simply ignoring the issue and attempting to turn the focus of attention elsewhere may work for a time but is unlikely to succeed in the longer term if crises of a similar nature continue to occur. Diversifying products, appealing to different markets and improving security arrangements may go some way towards supporting the sector, but if tourists continue to be the target of terrorist attacks, government travel advisory warnings will remain in place and tourists themselves will be too nervous to travel to the destination.

\footnotetext{
${ }^{4}$ Guidelines written for the Council of Australian Tour Operators on managing risks and crises in tourism are useful for industries in the sector - it is available at https://www.uts.edu.au/sites/default/files/20160329-Beirman-Risk-Crisis-Recovery-Tour-Wholesalers.pdf
} 


\section{REFERENCES}

\section{Sections 1, 2, 3 and Executive Summary and Introduction References}

ASEAN (2015) ASEAN Tourism Crisis Communications Manual

Arup, T. (2016) Barrier reef bleaching far worse than first surveyed. Sydney Morning Herald, 1 April

Aviation, Conservation and Travel News (2017) Kenya's Tourism Arrivals Grew by Over 16 Percent in 2016. https://wolfganghthome.wordpress.com/2017/02/01/kenyas-tourism-arrivals-grewby-over-16-percent-in-2016/

Avraham, E. (2015) Destination image repair during crisis: Attraction tourism during the Arab spring uprisings. Tourism Management 47, pp. 224-232

Avraham, E. (2016) Destination marketing and image repair during tourism crises: The case of Egypt. Journal of Hospitality and Tourism Management 28, pp. 31-40

Avraham, E. and Ketter, E. (2017) Destination marketing during and following crises: combating negative images in Asia, Journal of Travel \& Tourism Marketing 34(6), pp. 709-718

Aziz, H. (1995) Understanding attacks on tourists in Egypt. Tourism Management 16, pp. 91-95

Beaumont, N. and Dredge, D. (2010) Local tourism governance: a comparison of three network approaches, Journal of Sustainable Tourism 18(1), pp. 7-28

Belair-Gagnon, V. (2015) Social Media at BBC News. London: Routledge

Biggs, D., Hall, C.M. and Stoeckl, N. (2012) The Resilience of Formal and Informal Enterprises to Disasters: Reef Tourism in Thailand. Journal of Sustainable Tourism, 20(5), pp 645-665

Bloomberg (2015) Islamist Militant Attacks Leave Kenyan Tourism Industry Reeling.

Boeing (2015) Statistical Summary of Commercial Jet Airplane Accidents, 1959-2015

Buultjens, J., Ratnayake, I. and Gnanapala, A. C. (2015) From Tsunami to Recovery: The Resilience of the Sri Lanka Tourism Industry. In Ritchie, B. and Campiranon, K. (Eds.) Tourism Crisis and Disaster Management in the Asia-Pacific. Oxford: CAB International, Chapter 8

Calgaro, E. and Cochrane, J. (2009) Comparative Destination Vulnerability Assessment for Thailand and Sri Lanka: Sustainable Recovery and Resilience Building in the Tsunami Affected Region. Stockholm Environment Institute Project Report, Stockholm: Stockholm Environment Institute 
Campiranon, K. and Arcodia, C. (2007) Market segmentation in time of crisis: a case study of the MICE sector in Thailand, Journal of Travel \& Tourism Marketing 23 (2/3/4), pp. 151-161

Carlsen, J. (2006) Post-tsunami recovery strategies for the Maldives. Tourism Review International 10, pp. 69-79

Carlsen, J.C. and Hughes, M. (2008) Tourism Market Recovery in the Maldives After the 2004 Indian Ocean Tsunami, Journal of Travel \& Tourism Marketing, 23(2-4), pp.138-149

CATO: Council of Australian Tour Operators (2016) Tourism Risk, Crisis and Recovery Management Guide

Chakelian, A. (2017) Rise of the nationalists, New Statesman, 8 March

China Daily Asia (2015) 18 TransAsia Victims from Chinese Mainland. http://www.chinadailyasia.com/nation/2015-02/05/content_15224215.html

Christchurch \& Canterbury Tourism (2012). Greater Christchurch Visitor Sector Recovery Plan. http://tourismleisuregroup.co.nz/downloads/Greater.pdf

Cochrane, J. (2010) The Sphere of Tourism Resilience, in Tourism Recreation Research, 35(2), pp. $173-186$

Dahles, H. and Susilowati, T.P. (2015) Business Resilience in Times of Growth and Crisis. Annals of Tourism Research, 51, pp 34-50

Dawn (2016) Specialised training of mediapersons on disaster reporting needed, Karachi, 10 January

Doward, J. and McCum, R. (2017) Record number of big-spending tourists expected in UK this summer. The Observer, 2 July

Egypt Today (2017) Indian tourists visiting Egypt increase by 30\% in Q1 2017, 10 May ^

Fall, L.T. and Massey, J.E. (2005) The significance of crisis communications in the aftermath of 9/11. Journal of Travel \& Tourism Marketing 19(2-3), pp. 77-90

Fallon, F. (2008) From China to Indonesia: adapting to changing markets. In Cochrane, J. (Ed.) Asian Tourism: Growth and Change. Oxford: Elsevier, Chapter 28

Francis, J. (2015) Why we lifted our Burma Boycott after 10 years, responsibletravel.com (https://www.responsibletravel.com/copy/burma-boycott) 
Granville, F., Mehta, A. and Pike, S. (2016) Destinations, disasters and public relations: stakeholder engagement in in multi-phase disaster management. Journal of Hospitality and Tourism Management 28, pp. 73-79

Haddad, C., Nasr, A., Ghida, E. and Ibrahim, H. How to Re-emerge as a Tourism Destination after a Period of Political Instability, in The Travel and Tourism Competitiveness Report 2015.. World Economic Forum, Geneva

Hall, C.M. (2010) Crisis events in tourism: subjects of crisis in tourism. Current Issues in Tourism 13(5), pp. 401-417

Henderson, J. (2007) Managing Tourism Crises, Oxford: Butterworth-Heinemann

Hitchcock, M. and Putra, I.D. (2008) Old Tourists and New Tourists: Management challenges for Bali's tourism industry. In Cochrane, J. (Ed.) Asian Tourism: Growth and Change. Oxford: Elsevier, Chapter 17

Howard, E. (2014) Rwanda, 20 years on: how the country is rebuilding itself. The Guardian, 3 April

Fall, L.T. and Massey, J.E. (2005) The significance of crisis communication in the aftermath of 9/11: a national investigation of how tourism managers have re-tooled their promotional campaigns, Journal of Travel \& Tourism Marketing 19(2-3), pp. 77-90

Farrell, B. H. and Twining-Ward, L. (2004) Reconceptualizing tourism. Annals of Tourism Research 31(2), pp. 274-295

Farrell, B. H. and Twining-Ward, L. (2005) Seven Steps Towards Sustainability: Tourism in the Context of New Knowledge. Journal of Sustainable Tourism, 13(2), pp. 109-122

Ghaderi, Z., Mat Som, A.P. and Henderson, J. (2012) Case study: tourism crises and island destinations: Experiences in Penang, Malaysia. Tourism Management Perspectives 2/3, pp. 79-84

Gurtner, Y. (2016) Returning to paradise: Investigating issues of tourism crisis and disaster recovery on the island of Bali. Journal of Hospitality and Tourism Management 28, pp. 11-16

Hajibaba, H., Boztug, Y. and Dolnicar, S. (2016) Preventing tourists from cancelling in times of crisis. Annals of Tourism Research 60, pp. 48-62

Harmon, A. (2016) Islamophobia, Salem Press Encyclopedia

Hitchcock, M., King, V.T. and Parnwell, M.J.G. (Eds.) (1993) Tourism in South-east Asia. London: Routledge 
Hitchcock, M. and Darma Putra (2005) Bali bombings: tourism crisis management and conflict avoidance. Current Issues in Tourism 8, 62-76

Hussain, Y. and Bagguley, P. (2012) Securitized citizens: Islamophobia, racism and the 7/7 London bombings, The Sociological Review, 60, pp. 715-734

IATA Emergency Response Handbook

http://www.iata.org/publications/store/Pages/emergency-response-handbook.aspx

ITE Travel \& Tourism (2016) Russian Outbound Tourism: Where next? Moscow: ITE

Jiang, Y. and Ritchie, B.W. (2017) Disaster collaboration in tourism: motives, impediments and success factors. Journal of Hospitality and Tourism Management 31, pp. 70-81

Jin, X. and Sparks, B. (2017) Barriers to offering special interest tour products to the Chinese outbound group market, Tourism Management 59, pp. 205-215

Kapiki, S. (2012) The Impact of Economic Crisis on Tourism and Hospitality: Results from a Study in Greece. Central European Review of Economics \& Finance, 2(1), pp. 19-30

Ketter, E. (2016) Destination image restoration on Facebook: case study of Nepal's Gurkha earthquake. Journal of Hospitality and Tourism Management, 28, pp. 66-72

Khan, A.R. (Ed.) (2017) One Health Manual, Selangor, Malaysia: One Health University Network

Khodadadi, M. (2016) A new dawn? The Iran nuclear deal and the future of the Iranian tourism industry. Tourism Management Perspectives 18, pp. 6-9

Kongoley, P.S. (2015) The impact of Ebola on the tourism and hospitality industry in Sierra Leone, International Journal of Scientific and Research Publications 5(12), pp. 542-550

Laws, E. and Prideaux, B. (2005) Crisis management: a suggested typology, Journal of Travel \& Tourism Marketing, 19(2-3), pp. 1-8

Lim, W.M. (2017) Restoring tourist confidence and travel intentions after disasters: some insights from a rejoinder to a series of unfortunate events in Malaysian tourism. Current Issues in Tourism, 20(1), pp.38-42

Liu, B., Schroeder, A., Pennington-Gray, L. and Farajat, S.A.D. (2016) Source market perceptions: How risky is Jordan to travel to? Journal of Destination Marketing \& Management 5, pp. 294-304

Luft, O. (2009) BBC Correspondent Jon Leyne expelled from Iran, BBC News, 22 June 
McLeod, A., Morgan, N., Prakash, A. and Hinrichs, J. (2005) Economic and Social Impacts of Avian Influenza. Rome: Food \& Agriculture Organization

McManus, S., Seville, E., Vargo, J. and Brunsdon, D. (2008) Facilitated Process for Improving Organisational Resilience. Natural Hazards Review, 9(2), pp 81-90

Maldives Ministry of Tourism (2013) Baseline Analysis: Adaptation Capacity and Climate Change Vulnerability Impacts in the Tourism Sector. Malé: Ministry of Tourism

Mansfield, Y. and Winckler, O. (2015) Can this be spring? Assessing the impact of the "Arab Spring" on the Arab tourism industry. Tourism Review 63(2), pp. 205-223

Misrahi, T. (2016) How destinations can bounce back after terrorist attacks. Geneva: World Economic Forum

Mizrachi, I. and Fuchs, G. (2016) Should we cancel? An examination of risk handling in travel social media before visiting ebola-free destinations. Journal of Hospitality and Tourism Management, 28, pp. 59-65

Morakabati, Y., Page, S.J. and Fletcher, J. (2017) Emergency Management and Tourism Stakeholder Responses to Crises: A Global Survey. Journal of Tourism Research 56(3), pp. 299-316

Moreira, P. (2007) Aftermath of crises and disasters: notes for an impact assessment approach. In Laws, E., Prideaux, B. and Chon, K. (Eds.) Crisis Management in Tourism. Wallingford: CABI Publishing, Chapter 5

Morris, H. (2016) Natural disasters worse for tourism than terror attacks. The Telegraph, 29 March

Ndregjoni, Z. and Billa, L. (2010) The behaviour intention of tourists in making decisions on international travel. International Journal of Management Cases, Special Issue, pp. 637-642

Nugraha, A., Hamin, H. and Elliott, G. (2016) Tourism destination decisions: the impact of risk aversion and prior experience. Asia Pacific Journal of Tourism Research 21(12), pp. 1274-1284

Orchiston, C., Prayag, G. and Brown C. (2016) Organizational Resilience in the Tourism Sector. Annals of Tourism Research, 56, 145-148

Oxford Business Group (2015) Jordan's tourism industry feels the impact of regional volatility, The Jordan Times, 27 April

Pambudi, D., McCaughey, N. and Smyth, R. (2009) Computable general equilibrium estimates of the impact of the Bali bombing on the Indonesian economy. Tourism Management, 30(2), pp. 232-239 
PATA: Pacific Area Travel Association (2011) Bounce Back - Tourism Risk, Crisis and Recovery Management Guide. Bangkok: PATA

PR Week (2014) Analysis: Malaysia Airlines' mishandled response to the MH370 crisis. March 21

Putra, I.D.N. and Hitchcock, M. (2006) The Bali bombs and the tourism development cycle. Progress in Development Studies 6(2), pp. 157-166

Reynolds, E. (2014) Kashmir floods: india and Pakistan turn to social media after deadly monsoon kills 490. AFP, 15 September

Savage, I. (2013) Comparing the fatality risks in United States transportation across modes and over time. Research in Transportation Economics, 43(1), pp. 9-22

Sharma, S. (2016) Hoteliers say tourism nose-diving due to adverse media reporting. The Times of India, 11 July

Simpson, M.C., Gössling, S., Scott, D., Hall, C.M. and Gladin, E. (2008) Climate Change Adaptation and Mitigation in the Tourism Sector: Frameworks, Tools and Practices. UNEP, University of Oxford, UNWTO, WMO: Paris, France

Simpson, M.C. and Gladin, E. (2008) Good Practices: Natural Hazard Risk Management in the Caribbean Tourism Sector. Caribbean Regional Sustainable Tourism Development Programme (CRSTDP), Caribbean Tourism Organization, Barbados

Som, A. P. M., Masutani, S. and Ahmad, M. F. (2016) The Growth of Muslim Friendly and Halal Tourism in Inbound and Outbound Travel Market. The Macroeconomic Review, 5(5), Special Issue 2016, pp 10-17

Starmer-Smith, C. (2008) Crime puts tourists off South Africa, Telegraph Travel, 2 February

Tazayian, S. and Andrews, H. (2016) Impacts of crises and communication media on place image: A case study of Chilas, Pakistan. Journal of Destination Marketing \& Management 5, pp. 351-360

The Economist (2013) Haiti: Still waiting for recovery, 5 January

The Kenyan Camper (2016) Kenya's Tourism Statistics - The Numbers Game. https://thekenyancamper.com/2016/05/09/kenyas-tourism-statistics-the-numbers-game/

Thome, W.H. (2017) Kenya's Tourism Arrivals Grew by Over 16 Percent in 2016, Aviation, Conservation and Travel News, 1 February

Torney, C. (2016) Travellers say holiday safety is their main priority, Confused.com TourismFiji (2016) Tourism Action Group Activated, Fiji Sun Online, 27 February 
Travelmole (2014) Ebola's tourism impact on Africa, 22 May

UN (2015) Tourism and Disaster Risk. UN contribution to the consultation leading to the Third UN World Conference on Disaster Risk Reduction

UNECOSOC (2005) Major Issues in Tourism Development in the Asian and Pacific Region: Risk and crisis Management in Tourism. Note to the High-level Intergovernmental Meeting on Sustainable Tourism Development, pp 11-12

UNEP (2007) Disaster Risk Reduction in Tourism Destinations. UNEP, Nairobi

UNEP (2015) APELL: Awareness and Preparedness for Emergencies at Local Level. UNEP, Nairobi UNEP (2008) Climate Change Adaptation and Mitigation in the Tourism Sector: Frameworks, Tools and Practices. UNEP, Nairobi

UNEP in collaboration with CAST - Caribbean Alliance for Sustainable Tourism (2008) Disaster Risk Management for Coastal Tourism Destinations Responding to Climate Change. UNEP, Nairobi

UNISDR (United Nations Office for Disaster Risk Reduction) (n/d) Hyogo Framework for Action

UNWTO (2003) Crisis Guidelines for the Tourism Industry https://www.slideshare.net/Nostrad/crisis-guidelines-for-the-tourism-industry

UNWTO (2011) Toolbox for Crisis Communications in Tourism. UNWTO, Madrid

UNWTO (2017) Report of the Secretary-General to the Executive Council. Part I: Current situation and activities. (c) Priorities and Management Vision. Progress in the priorities for 2016-2017 http://cf.cdn.unwto.org/sites/all/files/pdf/ce105_03_c_priorities_and_management_vision_en.pd $\mathrm{f}$

UNWTO (2015) Tourism Highlights, 2014 edition, Madrid: UNWTO

UNWTO (2016) Tourism Highlights, 2015 edition, Madrid: UNWTO

UNWTO (2017) Tourism Highlights, 2016 edition, UNWTO, Madrid

UNWTO (2017) Press Release 17003. Sustained Growth in International Tourism despite challenges. UNWTO, Madrid

UNWTO and ILO (2013) Economic Crisis, International Tourism Decline and its Impact on the Poor 
Upadhya, A. (2014) Role of Destination Management Organization in Tourism Crisis Management: A Middle Eastern Perspective. Conference Paper for 3rd Interdisciplinary Tourism Research Conference, Istanbul, 3-7 June 2014

Walker, B., Holling, C.S., Carpenter, S.R. and Kinzig, A. (2004) Resilience, Adaptability and Transformability in Social-ecological Systems. Ecology and Society 9 (2): article 5.

Walters, G. and Mair, J. (2012) The effectiveness of post-disaster marketing messages: the case of the 2009 Australian bushfires, Journal of Travel \& Tourism Marketing 29(1), pp. 87-103

Walters, G., Mair, J. and Lim, J. (2016) Sensationalist Media Reporting of Disastrous Events: Implications for Tourism. Journal of Hospitality and Tourism Management 28, pp. 3-10

World Economic Forum (2015) The Travel and Tourism Competitiveness Report 2015, World Economic Forum, Geneva

World Travel Online (2017) Chinese Outbound Tourism in 2016, 3 February

WTTC: World Travel \& Tourism Council (2016) Exchange rate trends and travel and tourism performance. Special Report

Zandi, M. (2013) From Financial Crisis to Recovery. New Jersey: Pearson Education Ltd 


\section{Section 4 and 5 References}

\section{Indonesia Case Study References}

Agustan, A., Kausar, D. and Kriswati, K. (2016) Linking Interpretations with Amenities: Educating Visitors in Volcanic Environments, Tourism Leisure and Global Change, 3

Andari, D.W. (2008) Post-bomb lessons, Inside Indonesia, 13 January

Asean Briefing (2011) Master plan for acceleration and expansion of Indonesia economic development 2011-2025: Coordinating Ministry for Economic Affairs, Republic of Indonesia, pp.208.

BBC News (2012) The 12 October 2002 Bali bombing plot, 11 October

Bonner R. and Perlez J. (2005) Bali Bombings kill at least 25 in tourist spots. The New York Times, 2 October

Cochrane J. (2003) Ecotourism, conservation and sustainability: A Case Study of Brumo Tennger Semeru National Park, Indonesia (npublished doctoral thesis). Hull, UK: University of Hull

De Haan J. (2016) Big plans for tourism expansion in Indonesia: Indian Ocean Research Programme. Future Directions International, 19 October

EERI (2006) Special Earthquake Report: the Mw 6.3 Java, Indonesia, Earthquake of May 27, 2006

Gurtner Y. (2016) Returning to paradise: Investigating issues of tourism crisis and disaster recovery on the island of Bali.Journal of Hospitality and Tourism Management 28, pp. 11-19.

Ministry of National Development Planning (2014) Strategic environmental assessment master plan for acceleration and expansion of Indonesia's economic development (SEA MP3EI): Executive Summary. Jakarta: Ministry of National Development Planning

NASA Earth Observatory. Nov. 2010: Eruption at Mount Merapi, Indonesia https://earthobservatory.nasa.gov/NaturalHazards/view.php?id=46881

Nidom, C. A., Takano, R., Yamada, S., Sakai-Tagawa, Y., Daulay, S., Aswadi, D., Suzuki, T., Suzuki, Y., Shinya, K., Iwatsuki-Horimoto, K., Muramoto, Y. and Kawaoka Y. (2010) Influenza A (H5N1) Viruses from Pigs, Indonesia. Emerging Infectious Diseases 16(10), pp. 1515-1523 
Purwomarwanto, Y.L. and Ramachandran, J. (2015) Performance of tourism sector with regard to the global crisis-A comparative study between Indonesia, Malaysia and Singapore. The Journal of Developing Areas, 49 (4), pp. 325-339

Simpson, D. (2007) Indonesia to launch tourism campaign, but is ecotourism at risk? Wallingford: CABI Publishing

Suparwoko W. (2012) Tourism development in Indonesia, in Suparwoko, W. (Ed.) Towards Responsible Tourism: A community-based approach to tourism development in Indonesia. Lambert Academic Publishing, Chapter 4

Teguh, F. (n/d) Indonesia Tourism Recovery: Lessons and programme, presentation by Dr. Frans Teguh, Director of Tourism Destination Design and Investment, Ministry of Tourism, Indonesia.

The Jakarta Post (2009) Culture, tourism development on right track, 6 August

UNWTO (2016) Indonesia: Compendium of Tourism Statistics dataset, Madrid: UNWTO

UNWTO (2012) Tourism Highlights: 2012 Edition. Madrid: UNWTO

UNWTO (2016) Tourism Highlights: 20162 Edition. Madrid: UNWTO

World Travel and Tourism Council (WTTC) (2015) Travel and tourism: Economic Impact 2015Indonesia, pp. 20

\section{Interviews:}

Ms Ani Insani Rochmulyati, Director for Tourism Institutional Relations, Ministry of Tourism, Indonesia, pers. comm., Jakarta, 2nd May 2017

Mr I Gusti Ngurah Putra, Special Advisor for General Affairs to Secretary of Ministry, Ministry of Tourism, Indonesia, pers. Comm., Jakarta, 2 $2^{\text {nd }}$ May 2017

Mr Surana Surana - Deputy Director for Multilateral Cooperation, Ministry of Tourism, Indonesia, pers. Comm., Jakarta, $2^{\text {nd }}$ May 2017

Dr Devi Roza Kausar, Associate Professor and Dean of the Faculty of Tourism, University of Pancasila, Jakarta, pers. comm., Jakarta, 3rd May 2017

Ms Sarojini Imran, Lecturer in the Faculty of Tourism at the University of Pancasila, Jakarta, pers. comm., $3^{\text {rd }}$ May 2017

\section{Turkey Case Study References}

Cetinel F. and Medet Y. (2009) Public policy and sustainable tourism in Turkey, Tourismos: 4(3), pp. 35-50

Cruise Line International Association - CLIA (2017). 2017 State of the Industry, Washington D.C. 
Gulbahar, M.O. and Yildirim, F. (2015) Marketing efforts related to social media channels and mobile application usage in tourism: case study in Istanbul. Procedia: Social and Behavioural Sciences 195, pp. 453-462

Kuvan, Y. and Akan, P. (2012) Conflict and agreement in stakeholder attitudes: residents' and hotel managers' views of tourism-impacts and forest-related tourism development. Journal of Sustainable Tourism 20(4), pp. 571-584

Lanquar R. (2011) Tourism in the Mediterranean: Scenarios up to 2030: MedPro Report No1/July 2011 (updated 2013), EU

Le Monde (2016) What is known about the coup attempt in Turkey, July 15

Lowen M. (2016) Turkey tourism: an industry in crisis, BBC News, 17 June

Ministry of Tourism and Culture, Directorate General for Promotion: Campaign Briefing, Ankara

Ministry of Tourism and Culture (2007) Tourism Strategy of Turkey - 2023. Ankara

Morris, H. (2016) ) Turkey's tourism chapter is ending. This is more damaging than the terror attacks. Telegraph News, 18 July

The Orient Express: http://www.allaboutturkey.com/orientexp.htm

Ozen K.T. (2016) What will Turkish tourism do for 2017? Hurriyat Daily News, 26 December

The Guardian (2016) Turkey's tourism industry reels from a year to forget, 5 October

Tosun C., Timothy D. and Ozturk, Y. (2003) Growth, national development and inequality in Turkey. Journal of Sustainable Development, 11 (2\&3), pp.133-161

UNWTO (2012) Tourism Highlights: 2012 Edition. Madrid

UNWTO UNWTO (2015) Tourism Highlights: 2015 Edition. Madrid: UNWTO

UNWTO (2016) Tourism Highlights: 2016 Edition. Madrid: UNWTO

Unver, H.A (2016) The real challenge to Turkey's economy isn't terrorism. Harvard Business Review, 8 July

Yalol, M. (2015) History of Tourism Development in Turkey. In Egresi, I. (Ed.) Alternative Tourism in Turkey: role, potential development and sustainability. New York: Springer Publishing, Chapter 2 
WTTC, Travel \& Tourism economic impact (2016) Turkey, pp. 24

WTTC, Travel \& Tourism economic impact (2017) Turkey, pp.24

WTTC, Travel \& Tourism economic impact (2017) World, pp. 20

\section{Interviews:}

Mr. Ramazan Cokcevik, Directorate of Foreign Relations and EU Coordination, Ministry of Culture and Tourism, pers. comm., Ankara, 27 th April, 2017

Murat Arslan, Director of Operations, Crowne Plaza [Intercontinental Hotel Group], pers. comm., Ankara, $26^{\text {th }}$ April,2017

\section{Tunisia Case Study References}

BBC News (2013) Tunisia constituent assembly suspended pending talks, 6 August

BBC News (2014) Tunisia assembly passes new constitution, 27 January

BBC News Africa (2015a) Tunis attack: Gunmen kill tourists in museum rampage, 18 March

BBC News Africa (2015b) Tunisia Beach Attack, 11 July

Byrne E. (2013) Tunisian opposition leader shot dead, The Guardian, 7 February

Calder, S. (2017) Tunisia tourism gets surprise boost despite Foreign Office warnings. The Independent, 17 May

Cornell University Library (n.d) Arab Spring: A Research and Study Guide - Tunisia. Ithaca: Cornell University

Gobe E. (2010) The Gafsa Mining Basin between Riots and a Social Movement: Meaning and significance of a protest movement in Ben Ali's Tunisia. Working paper, $21 \mathrm{pp}$. France: HALS Archives-Ouvertes

JICA: Japan International Coperation Agency (2001) Study on Tourism Development Plan for the year 2016 in the Republic of Tunisia. Vol. II; Regional and Action Plan

Joyce R. (2013) Tunisialive NCA member Mohamed Brahmi assassinated: Tunisialive, July 25

Ministry of Tourism and Handicrafts- Tourism Statistics, http://www.tourisme.gov.tn/en/achievements-and-prospects/tourism-in-figures.html

Poirier R. A. (1995) Tourism and Development in Tunisia. Annals of Tourism Research, 22(1), pp. 157-171 
Raqiqi-al S. (2013) What Tunisia's phosphate crisis says about its state of affairs: Al-Munitor, 29 May; (document translated from Arabic by Steffi Chakti)

Reuters (2017) Tunisia sees 30 percent tourism growth in 2017, 21 March

Trading Economics: Tunisia Tourism Arrivals, http://www.tradingeconomics.com/tunisia/tourist-arrivals

Grierson, J. (2017) Tunisia Attack: how a man with a parasol could murder 38 people on the beach, The Guardian, 28 February

Tunisia's Tourism Strategy 2016, https://www.oecd.org/cfe/leed/46761318.pdf

Tunisia 2020 http://tunisia2020-548724.c.cdn77.org/wp-content/uploads/2016/11/Fichesprojets-en-anglais.pdf

Oxford Business Group (2017) The Report: Tunisia 2016. Oxford: Oxford Business Group

UNWTO (2010) Tourism Highlights: 2010 Edition. Madrid: UNWTO

UNWTO (2012) Tourism Highlights: 2012Edition. Madrid: UNWTO

UNWTO (2015) Tourism highlights: 2015 edition. Madrid: UNWTO

UNWTO (2016) Tourism Highlights: 2016 Edition. Madrid: UNWTO

Wismayer, H. (2016) Tunisia keen to show tourists that it's safe to return, The Guardian, 18 June

World Tourism and Travel country report (WTTC), 2017 Tunisia,Tunisia pp.24

Zguric, B. (2012) Challenges for democracy in countries affected by the 'Arab Spring', Islam and Christian-Muslim relations, 23(4), pp. 417-434

\section{Interviews:}

Ms Nabiha Boussetta, Director of Studies, Ministry of Tourism and Handicraft, Tunisia, pers. comm., Tunis, 24th April 2017

Ms Zeinab Zouaoui, Director of Health Tourism and Wellness Tourism, Ministry of Tourism and Handicraft , Tunisia, pers. comm., Tunis, 25 April 2017

\section{Gambia Case Study References}

Bah, A. and Goodwin, H. (2003) Improving Access for the Informal Sector to Tourism in The 
Gambia. Pro-Poor Tourism, Economic and Social Unit. Working Paper N15. London: Overseas Development Institute

Dahles, H. (2008) Romance and Sex Tourism, in Hitchcock, M., King, V.T., and Parnwell, M.J. (Eds.) (2008) Tourism in South East Asia: New Perspectives. Honolulu: University of Hawaii Pres

Dieke, P. (1993) Tourism and development policy in Gambia. Annals of Tourism Research 20, pp. $423-449$

Jones, T. (2003) Impacts of climate change on tourism in small island developing states and other coast areas. Presentation at $1^{\text {st }}$ international conference on climate change, Djerba, 9-11 April

Maclean, R. and Jammeh, S. (2017) New claims over scale of ex-Gambian leader's theft from state coffers, The Guardian, 23 February

Mitchell, J. and Ashley, C. (2007) Can tourism offer pro-poor pathways to prosperity? Examining evidence on the impact of tourism on poverty. Briefing paper no. 22. London: Overseas Development Institute

Mitchell, J. and Faal, J. (2007) Holiday package tourism and the poor in The Gambia, Development Southern Africa 24(3), pp. 445-464

Mizrachi, I. and Fuchs, G. (2016) Should we cancel? An examination of risk handling in travel social media before visiting ebola-free destinations. Journal of Hospitality and Tourism Management 28, p. 59-65

Republic of The Gambia (2006) The Gambia Tourism Development Master Plan, Department of State for Tourism and Culture / African Development Bank

Sharpley, R. (2007) Developing tourism in The Gambia. 'Tourism in The Gambia - 10 years on', Cutting Edge Research in Tourism - New Directions, Challenges and Applications. Guildford: School of Management, University of Surrey

Sharpley, R. (2009) Tourism and development challenges in the least developed countries: The case of The Gambia. Current Issues in Tourism, 12(4), 337-358

UNWTO (United Nations World Tourism Organisation) (various) Tourism Highlights. Madrid: UNWTO

Wheatcroft, 0. and Francis, J. (2011) All inclusive holidays - sinner or saint? Travel Trade Gazette, 6 May

World Economic Forum (2017) The Travel and Tourism Competitiveness Report 2017. Geneva: WEF 


\section{Interviewees}

Mr Mamodou Bah, Director of Quality Control, Gambia Tourist Board, pers. comm. 21 April 2017 Ms Mrs Fatou Beyai-Raji, Director of Product Development, Gambia Tourism Board, 21 April 2017

Mrs Lucy McCombes, Research Fellow, Leeds Beckett University, Principal Investigator in Ninki Nanka Trail Feasibility Study, 18 April 2017

Mr Adama Njie, Director of Marketing, Gambia Tourist Board, pers. comm., 21 April 2017

Dr Davina Stanford, Senior Lecturer, Leeds Beckett University, leader of study tour group to The Gambia in January 2017, 22 March 2017

\section{South Africa Case Study References}

BizNews (2014) Paid to kill golden goose: Bell Pottinger takes SA Tourism money as it strangles South Africa, 14 June.

Department of Tourism (2011) National Tourism Sector Strategy 2011-2020, Department of Tourism, Republic of South Africa

Emmanuel, K. (2017) Weaker rand, more pros than cons, report in Southern Africa Tourism Update, 11 April

Frost, D. (2017) CEO of Southern Africa Tourism Services Association, cited in Alfred, L., Holme, T. and Goko, C. (2017) How SA tourism missed the boat, Financial Mail (South Africa), 10 January

Groenewald, J. (2017) MD of Royal African Discoveries, cited in Alfred, L., Holme, T. and Goko, C. (2017) How SA tourism missed the boat, Financial Mail (South Africa), 10 January

IMD (International Institute for Manager Development) (2016) Competitiveness Report, report on South African business analysis website, businesstech.co.za, 31 May

Mintel (2017) Travel and Tourism - South Africa. Mintel Group Ltd.

Oxford Business Group (2015) South African tourism sector pulling through challenges, 20 May

Rogerson, C.M. (2013) Tourism and local development in South Africa: Challenging local governments. African Journal for Physical, Health Education, Recreation and Dance, September (Supplement 2), pp. 9-23

Saunders, G. (2017) The South African Tourism Sector: An Economic Outlook. Johannesburg: Grant Thornton 
Shaw, G., Saayman, M. and Saayman, A. (2012) Identifying risks facing the South African tourism industry. South African Journal of Economic and Management Sciences, 15(2)

South African Tourism (2014) Strategic Plan 2015-20. Johannesburg: South African Tourism

TBCSA (Tourism Business Council of South Africa (n/d) Tourism Safety Initiative - About us (http://www.tourismsafety.co.za/about-us/)

UNWTO (United Nations World Tourism Organisation) (various) Tourism Highlights. Madrid: UNWTO

World Economic Forum (2017) The Travel and Tourism Competitiveness Report 2017. Geneva: WEF

World Travel \& Tourism Council (2017) Travel \& Tourism Economic Impact 2017, South Africa. London: WTTC

\section{Interviewees (Johannesburg)}

Ms Aneme Malan, Deputy Director General of Tourism, Department of Tourism, 9 May 2017

Mr Kingsley Makhubela, CEO of Brand South Africa, 10 May

Ms Judi Nwokedi, CEO of Tourvest and Board member, South African Tourism, 10 May

Ms Gillian Saunders, Global Lead, Travel, Tourism \& Leisure, Grant Thornton, 11 May

Ms Mmatsatsi Ramawela, CEO of Tourism Business Council of South Africa, 11 May

Ms Margie Whitehouse, Marketing Director of South African Tourism, Thurs 11 May

\section{UK Case Study References}

Baxter, E. and Bowen, D. (2004) Anatomy of Tourism Crisis: exploring the effects on tourism of the UK Foot and Mouth Disease epidemics of 1967-68 and 2001 with special reference to media portrayal. International Journal of Tourism Research 6, pp 263-273

Blake, A., Sinclair, M.T. and Sugiyarto, G. (2003) Quantifying the effect of foot and mouth disease on tourism and the UK economy, Tourism Economics 9(4), pp. 449-465

Briedenhann, J. (2008) The Role of the Public Sector in Rural Tourism: Respondents' Views. Current Issues in Tourism 10(6), pp.584-607

CMSC (2001) Tourism - the Hidden Giant - and Foot and Mouth. Culture, Media and Sport Committee, Fourth Report, Vol. 1. London: The Stationery Office

CMSC (2008) Tourism, Eighth report of Session 2007-08, London: The Stationery Office

CMSC (2015) Tourism, Sixth report of Session 2014-15, Culture, Media and Sport Committee. London: The Stationery Office 
Cochrane, J. (2009) Changing landscapes and rural tourism, in Thomas, R. (Ed.) Managing Regional Tourism: A Case Study of Yorkshire, England, Ilkley: Great Northern Books, pp. 65-77 Donaldson, A., Lee, R., Ward, N. and Wilkinson, K. (2006) Foot and Mouth - five years on: the legacy of the 2001 Food and Mouth Disease crisis for farming and the British countryside. Centre for Rural Economy Discussion Paper no. 6, University of Newcastle-upon-Tyne

Dorsett, R. (2013) The effects of the Troubles on GDP in Northern Ireland, European Journal of Political Economy (29), pp. 119-133

Financial Management (2001) Food and mouth crisis slaughters rural tourism industry across UK, April

Kennell, J. and Chaperon, S. (2013) Analysis of the UK Government's 2011 tourism policy. Cultural Trends 22(3-4), pp. 278-284

Leslie, D. and Black, L. (2005) Tourism and the Impact of the Foot and Mouth Epidemic in the UK, Journal of Travel and Tourism Marketing 19(2-3), pp.35-46

Miller, G.A. and Ritchie, B.W. (2003) A farming crisis or a tourism disaster? An analysis of the Foot and Mouth Disease in the UK. Current Issues in Tourism 6(2), pp. 150-171

Mintel (2014) Inbound tourism - UK. London: Mintel Group

Mintel (2016) Domestic tourism - UK. London: Mintel Group Ltd

Oxford Economics (2013) Tourism: jobs and growth. London: Deloitte

Page, S.J. (2015) Tourism Management (5 ${ }^{\text {th }}$ Edn.). London: Routledge

Page, S., Song, H. and Wu, D.C. (2012) Assessing the impacts of the Global Economic Crisis and Swine Flu on inbound tourism demand in the United Kingdom, Journal of Travel Research 51(2), pp. $142-153$

Sharpley, R. and Craven, R. (2001) The 2001 Foot and Mouth Crisis - Rural economy and tourism policy implications: A comment. Current Issues in Tourism 4(6), pp. 527-537

\section{Thailand Case Study References}

BBC News report (2016) Thailand to close Koh Tachai island over tourism damage, 17 May

Beirman, D. (2016) Safety and security in tourism - recovery marketing after crises, Journal of Policy Research in Tourism, Leisure and Events 8(1), pp. 98-106 
Biggs, D., Hall, C.M. and Stoeckl, N. (2012) The resilience of formal and informal tourism enterprises to disasters: reef tourism in Phuket, Thailand. Journal of Sustainable Tourism 20(5), pp. 645-665

Business Monitor International (2016) Thailand Tourism Report Q1 2017. London: BMI Research

Campiranon, K. and Arcodia, C. (2008) Market Segmentation in Time of Crisis, Journal of Travel \& Tourism Marketing 23(2-4), 151-161

Campiranon, K. and Scott, N. (2014) Critical success factors for crisis recovery management: a case study of Phuket hotels. Journal of Travel \& Tourism Marketing 31(3), pp. 313-326

Cohen, E. (2014) Tourism encroachment on reserved forest areas: a case study from Thailand. Tourism Recreation Research 39(2), pp. 185-202

Ghaderi, Z., Mat Som, A.P. and Henderson, J. (2015) When disaster strikes: the Thai floods of 2011 and tourism industry response and resilience. Asia Pacific Journal of Tourism Research 20(4), pp. 399-415

Kontogeorgopolous, N. (1998) Tourism in Thailand: patterns, trends and limitations. Pacific Tourism Review 2, pp. 225-238

Kanlayanasukho, V. (2014) An Analysis of the Tourism Industry's Management Responses to Political Crises in Thailand. In Ritchie, B.W. and Campiranon, K. (2014) Tourism crisis and disaster management in the Asia-Pacific. Wallingford: CABI Publishing, Chapter 8, pp. 116-131

Kontogeorgopolous, N., Curyen, A. and Duangsaeng, V. (2015) Homestay tourism and the commercialization of the rural home in Thailand, Asia Pacific Journal of Tourism Research 20(1), pp. 29-50

Mintel (2015) Travel and Tourism - Thailand. London: Mintel Group Ltd.

Nidhiprabha, B. (2007) Adjustment and recovery in Thailand two years after the tsunami. Discussion Paper no. 72. Tokyo: Asian Development Bank Institute

PwC (2015) Surviving disaster: How to reemerge as a tourism destination after a period of political instability, available at: http://www.strategyand.pwc.com/media/file/Survivingdisaster.pdf

Ritchie, B.W. and Campiranon, K. (2014) Tourism crisis and disaster management in the AsiaPacific. Wallingford: CABI Publishing

Shepherd, N. (2002) How ecotourism can go wrong. Current Issues in Tourism 5(3\&4), pp. 309-318 
Sofield, T. (2008) The Role of Tourism in Transition Economies of the Greater Mekong Subregion, in Cochrane, J. (Ed.) Asian Tourism: Growth and Change. Oxford: Elsevier Press, Chapter 4, pp. 39-54

Suansri, P. and Richards, P. (2013) A case study of community-based tourism in Thailand. In World Tourism Organization (Ed.), Domestic tourism in Asia and the Pacific (pp. 529-551). Madrid: UNWTO

UNWTO (2016) Tourism Highlights: 2016 Edition. Madrid: UNWTO

UNWTO/GTERC (2016) Annual Report on Asia-Pacific Tourism Trends - 2016 Edition. Madrid: UN World Tourism Organization / Global Tourism Economy Research Centre

Wattanacharoensil, W. and Schuckert, M. (2016) Reviewing Thailand's master plans and policies: implications for creative tourism? Current Issues in Tourism 19(10), pp. 1045-1070

\section{Interviewees}

Pongponrat, K. (2017) Tourism researcher and consultant, Thammasat University, Bangkok, personal communication, 6 April

Richards, P. (2017) Tourism consultant and business owner based in Thailand, personal communication, 6 April

\section{Sri Lanka Case Study References}

Bhandari H. and Goel P. (2017) Market Pulse: Colombo, Katunayake and Negombo-Sri Lanka. HVS, Feb.

Buultgens, J. W., Ratnayake, I. and Gnanapala, A.C. (2016) Post-conflict tourism development in Sri Lanka: Implications for building resilience. Current Issues in Tourism 19(4), pp. 355-372

Cochrane, J. (2008) Responses to continuing crisis in Sri Lanka, in Cochrane, J. (Ed.) Asian Tourism: Growth and Change. London: Elsevier, pp. 79-92

Cochrane, J. (2009) Resilience \& Recovery: Tourism in Sri Lanka after the Asian Tsunami (Project Report), Stockholm Environment Institute

De Bruin, A. and Nithiyanandam, V. (2000) Tourism in Sri Lanka: Paradise on Earth? In C. M. Hall and S. Page (Eds.) Tourism in South and Southeast Asia: issues and cases. London: Butterworth-Heinemann, pp. 235-257

Fernando, S., Bandra, J. S. and Smith, C. (2013) Regaining missed opportunities: The role of tourism in post-war development in Sri Lanka. Asia Pacific Journal of Tourism Research 18(7), pp. 685-711 
Mann, S. S. and Goel, P. (2014) Sri Lanka Tourism: Moving full steam ahead. Gurgaon, India: HVS

McKercher, B. and Pine, R. (2006) Privation as a stimulus to travel demand? In E. Laws and B. Prideaux (Eds.) Tourism crises: management responses and theoretical insights. Binghampton: Haworth Hospitality Press, pp. 107-116

Ministry of Economic Development, Sri Lanka (2011) Tourism development strategy 20112016. Colombo: Sri Lanka Tourism Development Authority

SLTB: Sri Lanka Tourist Board (2006) Sri Lanka Tourism Strategic Marketing Plan 2007-2009. Colombo: Sri Lanka Tourist Board

SLDTA: Sri Lanka Tourism Development Authority (2012) Annual Statistical Report, Research \& International Relations Division

Tourism Act No.38 (2005) Parliament of Democratic Socialist Republic of Sri Lanka. Supplement to Part II of the Gazette of the Democratic Socialist Republic of Sri Lanka of December 02

Tourism Infrastructure Projects- Sri Lanka Tourism http://www.sltda.gov.lk/projects

Tourism Research and Statistics - Sri Lanka Tourism www.sltda.lk/statistics

UNWTO: UN World Tourism Organization (2005) Post tsunami re-assessment: growing demand, limited supply. Madrid: UNWTO

UNWTO (2016) Tourism Highlights: 2016 Edition. Madrid: UNWTO

UNWTO (2017) Tourism Highlights, 2016 edition, UNWTO, Madrid

UNWTO/GTERC (2016) Annual Report on Asia-Pacific Tourism Trends - 2016 Edition. Madrid: UNWTO

USAID (2004) The Competitive Context of the Sri Lanka Tourism Industry. Washington, DC: USAID

Welgamage, P-P. L. (2015) Tourism Economics in Sri Lanka: An economic analysis. International Journal of Business and Social Research 5(1), pp.90-101

WTO: World Tourism Organization (2000) Tourism 2020 Vision: Volume 6, South Asia. Madrid: World Tourism Organization

World Bank (2005) Tsunami Recovery in Sri Lanka: Damage and Needs Assessment, Annex XIV - Tourism. World Bank: Washington, DC

Almeida, K. (2017) Importance of remittance to Sri Lanka and its future in digital world. Daily Mail (Sri Lanka), 7th April 


\section{Section 6 References}

Beirman, D. (2016) Tourism risk, crisis and recovery management guide, Council of Australian Tour Operators

Calgaro, E. and Cochrane, J. (2009) Comparative Destination Vulnerability Assessment for Thailand and Sri Lanka: Sustainable Recovery and Resilience Building in the Tsunami Affected Region. Stockholm Environment Institute Project Report, Stockholm: Stockholm Environment Institute

The Guardian (2017) Emergency landing: how airlines can recover from a PR disaster, 30 May https://www.theguardian.com/business/shortcuts/2017/may/30/british-airwaysemergency-landing-how-airlines-recover-pr-disaster

The Telegraph (2017) Tunisia beach massacre: security forces deliberately delayed arrival at Sousse hotel, inquest finds, report by defence correspondent, 16 January http://www.telegraph.co.uk/news/2017/01/16/tunisia-beach-massacre-inquests-duebegin/

Yousef, D.K. (2017) Egypt to diversify tourism and target new markets in recovery plan, Bloomberg reported on www.skift.com, 24 April https://skift.com/2017/04/24/egypt-to-diversify-tourism-and-target-new-markets-inrecovery-plan/ 